UNIVERSIDADE DE SÃO PAULO

FACULDADE DE FILOSOFIA, LETRAS E CIÊNCIAS HUMANAS DEPARTAMENTO DE LETRAS CLÁSSICAS E VERNÁCULAS PROGRAMA DE PÓS-GRADUAÇÃO EM LITERATURA BRASILEIRA

GISELE GEMMI CHIARI

\title{
A ESTÉTICA ROMÂNTICA NO TEATRO DE GONÇALVES DIAS: LEONOR DE MENDONÇA
}

São Paulo

2015 
FACULDADE DE FILOSOFIA, LETRAS E CIÊNCIAS HUMANAS

DEPARTAMENTO DE LETRAS CLÁSSICAS E VERNÁCULAS

PROGRAMA DE PÓS-GRADUAÇÃO EM LITERATURA BRASILEIRA

\section{A ESTÉTICA ROMÂNTICA NO TEATRO DE \\ GONÇALVES DIAS: LEONOR DE MENDONÇA}

\section{Gisele Gemmi Chiari}

Tese apresentada ao Programa de PósGraduação em Literatura Brasileira do Departamento de Letras Clássicas e Vernáculas da Faculdade de Filosofia, Letras e Ciências Humanas da Universidade de São Paulo como requisito parcial à obtenção do título de Doutor em Letras.

Orientador: Prof. Dra. Cilaine Alves Cunha

São Paulo

2015 
Autorizo a reprodução e divulgação total ou parcial deste trabalho, por qualquer meio convencional ou eletrônico, para fins de estudo e pesquisa desde que citada a fonte.

Chiari, Gisele Gemmi

A estética romântica no teatro de Gonçalves Dias: Leonor de Mendonça/ Gisele Gemmi Chiari; orientador Cilaine Alves Cunha. São Paulo, 2015.

$223 \mathrm{p}$.

Tese (Doutorado - Programa de Pós-Graduação em Literatura Brasileira. Área de Concentração: Literatura Brasileira) - Faculdade de Filosofia, Letras e Ciências Humanas da Universidade de São Paulo.

1. Literatura Brasileira. 2. Romantismo. 3. Gonçalves Dias. 4. Leonor de Mendonça. 


\section{FOLHA DE AVALIAÇÃO}

Gisele Gemmi Chiari

A estética romântica no teatro de Gonçalves Dias: Leonor de Mendonça

Tese apresentada ao Programa de PósGraduação em Literatura Brasileira do Departamento de Letras Clássicas e Vernáculas da Faculdade de Filosofia, Letras e Ciências Humanas da Universidade de São Paulo como requisito parcial à obtenção do título de Doutor em Letras.

Aprovado em:

Banca Examinadora

Prof. Dr.

Instituição: Assinatura:

Prof. Dr.

Instituição: Assinatura:

Prof. Dr.

Instituição: Assinatura:

Prof. Dr.

Instituição: Assinatura: 


\section{AGRADECIMENTOS}

Gostaria de agradecer primeiramente à minha orientadora, professora Cilaine Alves Cunha, pelo rigor com que orientou meus estudos, pela constância e paciência.

Agradeço aos professores João Roberto Faria e Marcos Flamínio Peres pelas valiosas observações e sugestões feitas durante o exame de qualificação.

Sou muito grata também ao meu marido Fabio que contribuiu com sua leitura e com seu apoio.

Meus agradecimentos ao Cássio por me ajudar a prosseguir.

Por fim, reconheço o apoio fundamental dado pela Coordenação de Aperfeiçoamento de Pessoal de Nível Superior (CAPES) que financiou esta pesquisa. 


\section{RESUMO}

Os estudos sobre Leonor de Mendonça não são muito numerosos e geralmente se articulam a capítulos ou prefácios que versam sobre a produção dramática de Gonçalves Dias como um todo ou acerca do teatro romântico no Brasil. A presente tese se propõe a apresentar um estudo mais extenso e aprofundado da obra prima gonçalvina. A escolha dessa peça também se deveu ao célebre Prólogo que a antecede, pois ele discute aspectos importantes da estética romântica dialogando com as produções europeias e sobretudo com o Prefácio de Cromwell de Victor Hugo. O escopo deste trabalho é analisar o drama Leonor de Mendonça privilegiando o contexto de produção da obra do ponto de vista estético. Nesse sentido, o exame da peça abrangerá um estudo sobre os gêneros dramáticos em voga no período e a relação da obra gonçalvina com essas estéticas teatrais. A ideia é perceber como os elementos do drama burguês, do melodrama, do drama histórico e romântico bem como aspectos da literatura gótica estão imbricados no texto em questão. Além disso, a permanência de elementos clássicos e neoclássicos também será discutida ao longo dos capítulos do presente estudo. $\mathrm{O}$ intento desse exame é assinalar como a comunicação com esses gêneros contribui para o desenvolvimento do drama. Nesse exercício transparece de forma mais tangível o diálogo de Gonçalves Dias com Victor Hugo e também a interação com as tragédias de Schiller. Considerada um drama histórico, com efeito, a obra em questão se estrutura inter-relacionando características de diferentes gêneros. Mais do que o resultado de uma relação intergêneros, em Leonor de Mendonça as diversas experiências estéticas do autor foram subsumidas na composição conformando-se em um drama efetivamente romântico de enredo trágico e conteúdo crítico que ainda permanece atual. Este trabalho também compara a peça gonçalvina com dramas e tragédias brasileiros coetâneos a fim de demonstrar a singularidade da história da duquesa de Bragança nesse contexto em que a estética romântica no teatro ainda não fora totalmente compreendida ou admitida. De uma perspectiva mais ampla, pretende-se com a presente tese contribuir para o estudo do teatro de Gonçalves Dias e a pesquisa sobre o romantismo no Brasil.

Palavras-chave: Literatura Brasileira. Romantismo. Gonçalves Dias. Leonor de Mendonça. 


\begin{abstract}
Studies about Leonor de Mendonça are not very numerous and they usually are articulated with chapters or prefaces that deal with the dramatic production of Gonçalves Dias as a whole or on the romantic theater in Brazil. This thesis aims to present a more extensive and detailed study of the Dias' masterpiece. The choice of this play was also due to the famous Prologue that precedes it, as it discusses important aspects of romantic aesthetic and dialogue with European productions, especially with the Preface of Cromwell by Victor Hugo. The scope of this work is to analyze the drama Leonor de Mendonça focusing on the context of production from the aesthetic point of view. In this sense, the examination of the sample cover a study on the dramatic genres in vogue in the period and the relation of Gonçalves Dias' work with these theatrical aesthetic. The idea is to understand how the elements of the bourgeois drama, melodrama, historical and romantic drama as well as aspects of gothic literature are embedded in the text in question. In addition, the permanence of classical and neoclassical elements will also be discussed throughout the chapters of this study. The intent of the review is to point out how communication with these genres contributes to development of the drama. In this exercise transpires more tangibly G. Dias' dialogue with Victor Hugo as well as interaction with Schiller's tragedies. Considered a historical drama, in fact, the play is structured by interrelating characteristics of different genres. More than the result of an inter-gender relationship, Leonor de Mendonça shows that various aesthetic experiences of the author have been subsumed in the composition and conformed in a romantic drama of tragic plot and critical content that even now remains current. This paper also compares the play in question with contemporary Brazilian dramas and tragedies in order to demonstrate the uniqueness of the history of duchess of Bragança in this context which the romantic aesthetic in the theater was not yet fully understood or accepted. From a broader perspective, this thesis intends to contribute to the study of Gonçalves Dias' theater and the research on romanticism in Brazil.
\end{abstract}

Keywords: Brazilian Literature. Romanticism. Gonçalves Dias. Leonor de Mendonça. 


\section{SUMÁRIO}

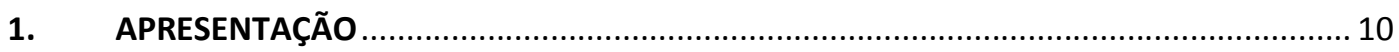

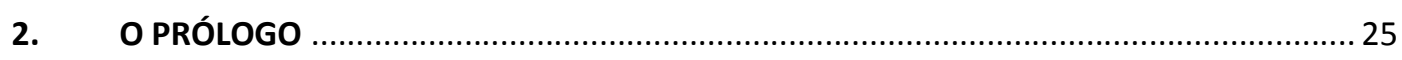

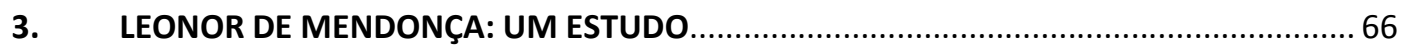

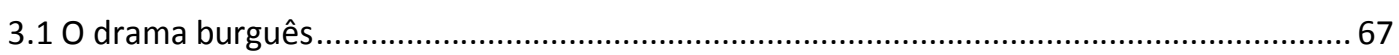

3.1.1.0 âmbito doméstico, a coerção social e o psicologismo .................................................... 73

3.20 melodrama

3.2.1 Leonor de Mendonça e a recusa da estética do melodrama............................................ 94

3.3 Breves considerações sobre aspectos da tragédia antiga e neoclássica em Leonor de

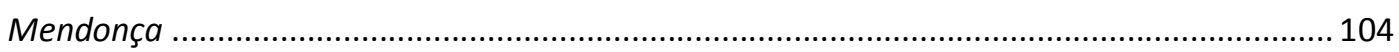

3.4 Elementos byronianos e góticos .......................................................................... 112

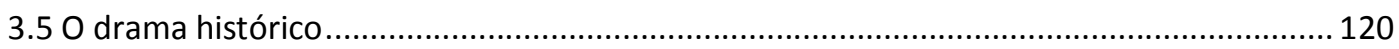

3.5.1. Entre a tragédia schilleriana e o drama hugoano ............................................................ 126

3.6 O drama romântico......................................................................................... 146

3.7 Considerações sobre determinadas falas das personagens e o estilo de linguagem ......... 155

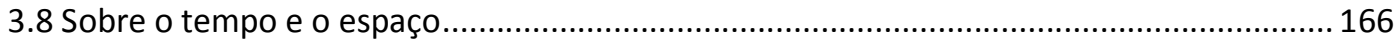

3.9. Leonor de Mendonça no contexto teatral brasileiro oitocentista .................................... 181

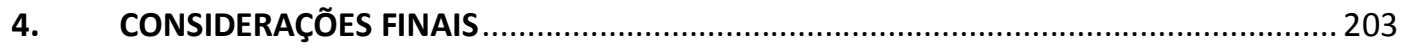


The lamp of life seemed to be spending itself to chase the vapours of a dungeon which no art could dissipate - And to what purpose did she rally all her energy? - Was not the world a vast prison and women born slaves?

Mary Wollstonecraft 


\section{APRESENTAÇÃO}

O drama Leonor de Mendonça foi a terceira obra teatral produzida por Gonçalves Dias e a única publicada em vida. Ao todo o autor escreveu quatro dramas, Patkull em 1843, Beatriz Cenci em 1844-1845, ambos em Portugal, Leonor de Mendonça em 1846 e Boabdil em 1850. Todas as peças têm como característica o aproveitamento de matéria histórica. Em Beatriz Cenci e Boabdil, por exemplo, sobressaem aspectos melodramáticos, embora a concepção de drama baseie-se no modelo francês de Victor Hugo e Alexandre Dumas, e Beatriz antecipe, em muitos aspectos, a obra prima do autor. Já Patkull dialoga com a concepção trágica de Schiller, pois nesse drama, como em Leonor de Mendonça, são principalmente as condições histórico-sociais, bem como a complexão psicológica, social e moral das personagens que determinam a tragicidade. Outra concepção importante do teatro schilleriano presente nas obras do dramaturgo brasileiro é o conflito vivido pelos protagonistas cindidos entre o dever e as paixões ${ }^{1}$. No entanto, Patkull, em termos de eficácia teatral, é enfraquecido pela falta de intersecção entre o substrato histórico e o entrecho amoroso. As falas das personagens que versam sobre o contexto da Guerra dos Trinta Anos são extensas e, em geral, não se coadunam com as ações, tornando-as acessórias e enfadonhas. Leonor de Mendonça, considerada a melhor obra teatral do poeta, juntamente com o seu Prólogo, demonstra uma consciência artística em consonância com a estética romântica e com as produções dramáticas europeias, sobretudo com a teoria aventada por Victor Hugo sobre o drama no célebre Prefácio de Cromwell, destoando do que vinha sendo produzido no teatro brasileiro da época.

Os estudos sobre a obra dramática de Gonçalves Dias aparecem, em geral, como parte de compêndios sobre o teatro brasileiro ou sobre o teatro romântico nacional. Poucas são as pesquisas que se detêm na investigação de aspectos específicos das peças gonçalvinas. Elas apresentam, em sua maioria, um quadro geral e sintético dessas produções. Ruggero Jacobbi foi contra essa tendência ao escrever a obra Goethe, Schiller e Gonçalves Dias ${ }^{2}$, fazendo um estudo minucioso e arguto da obra teatral do autor brasileiro. Jacobbi, aliás, chama atenção para a dificuldade da pesquisa sobre o

\footnotetext{
${ }^{1}$ VOLOBUEF, Karin. Friedrich Schiller e Gonçalves Dias. Pandaemonium germanicum. São Paulo: Humanitas, v. 9, 2005, p. 85.

2 JACOBBI, Ruggero. Goethe, Schiller e Gonçalves Dias. Porto Alegre: Edições da Faculdade de Filosofia/, Série Letras, vol. V, 1958.
} 
assunto devida (também) ao desprezo dos críticos e biógrafos pelos dramas gonçalvinos. O desprezo pela obra dramática de Gonçalves Dias deve-se à predileção pelo estudo de sua poesia, sobretudo a indianista, a qual respondeu aos anseios políticos do Império de criação da identidade nacional ${ }^{3}$. José Veríssimo, por exemplo, não deixa de elogiar as produções teatrais do autor, mas pontua que a "obra puramente poética de Gonçalves Dias sobrepujou em acabamento e mérito a tudo mais que escreveu...". ${ }^{4}$

Dois elementos dificultam o estudo do teatro de Gonçalves Dias. O primeiro é a pouca atenção dada pelos biógrafos e críticos (com a honrosa exceção de Silvio Romero) a esta parte de sua obra. A lenda do escasso valor dos dramas continua até hoje, embora se comece a abrir uma exceção para "Leonor de Mendonça" $[\ldots]^{5}$

Em sua História da Literatura Brasileira, Sílvio Romero comenta que, mesmo não tendo visto os dramas de Gonçalves Dias em cena, os apreciava. Ele acrescenta que Leonor de Mendonça, por exemplo, bem representada, seria "grandemente dramática". Para o crítico, as cenas na casa do velho Afonso Alcoforado são as mais belas devido não somente à atmosfera criada pelo autor, mas principalmente pela luta interior travada pelo jovem cavaleiro entre o respeito pelo pai e o amor pela duquesa ${ }^{6}$.

Outros estudiosos do teatro como Décio de Almeida Prado ${ }^{7}$, Sábato Magaldi ${ }^{8}$ e João Roberto Faria ${ }^{9}$ são unânimes em considerar os dramas gonçalvinos de excelente

\footnotetext{
3 "Passados um século e meio de sua morte, o autor ainda é interpretado pelo filtro poético. No entanto, poesia, drama, crítica, etnografia e tradução compõem obviamente uma mesma atividade artística, de idêntica incompletude: um vasto borrão feito de rigor e turbulência, um 'zilbadone 'leopardiano, borrão no qual o poeta, ao modo do colega italiano, jogou ideias, anseios, impressões, sntimentos - a orgia do logos." GIRON, Luís Antônio. A bacanal do espírito: Gonçalves Dias folhetinista e a crítica de jornal na primeira geração romântica brasileira. Tese. 668 p., Escola de Comunicações e Artes da Universidade de São Paulo, São Paulo, 2004, p. 422-423.

${ }^{4}$ VERÍSSIMO, José. História da Literatura Brasileira: de Bento Teixeira (1601) a Machado de Assis (1908). 4. ed., Brasília: Editora Universidade de Brasília, 1963.

${ }^{5}$ JACOBBI, Ruggero. Op. Cit., p. 46.

${ }^{6}$ ROMERO, Sílvio. História da Literatura Brasileira: Transição e Romantismo. Tomo Terceiro. 5 ed., Rio de Janeiro: Livraria José Olympio, 1953, p. 1022.

7 “A primeira, em ordem cronológica e também em ordem de qualidade, é Leonor de Mendonça, não só o mais belo drama romântico brasileiro, mas o único que tem sido revivido com certa frequência em versões modernas." PRADO, Décio de Almeida. História concisa do teatro brasileiro: 1570-1908. São Paulo: Editora da Universidade de São Paulo, 1999, p. 47.

8 Segundo Magaldi, Gonçalves Dias: "Fez, em Leonor de Mendonça, um drama sóbrio e elevado. Certamente a melhor obra do gênero em nossa literatura dramática do século XIX." MAGALDI, Sábato. Panorama do teatro brasileiro. Rio de Janeiro: Serviço Nacional de Teatro; DAC/FUNARTE; Ministério da Educação e Cultura, s.d., p. 74.

9 "Os comentários de Gonçalves Dias a respeito do enredo e das personagens de Leonor de Mendonça são primorosos, tanto quanto o próprio drama.” FARIA, João Roberto. Ideias teatrais: o século XIX no Brasil. São Paulo: Perspectiva; FAPESP, 2001, p. 48.
} 
qualidade comparados aos de outros dramaturgos brasileiros coetâneos ${ }^{10}$. Por sua vez, o crítico e historiador da literatura José Veríssimo ressalta que, do ponto de vista teatral, os dramas gonçalvinos não são inferiores aos de Magalhães e seus companheiros. Sobre Leonor de Mendonça afirma ser a peça superior como criação artística e pelo mérito literário ${ }^{11}$, comparando-a em sobriedade e singeleza ao estilo do Frei Luís de Souza de Almeida Garrett.

Em sua obra $O$ drama romântico brasileiro, Décio de Almeida Prado escreveu um elucidativo estudo sobre os dramas gonçalvinos, sobretudo a respeito de Leonor de Mendonça. O pesquisador chama atenção para a "fatalidade determinista de cunho social (e psicológico)" da peça em questão, a qual revela a subordinação dos mais fracos, especificamente a submissão de Leonor por ser mulher, e a de Alcoforado por pertencer a um estrato mais baixo da escala social. Para Prado, d. Jaime interpreta o amor de Alcoforado como um desafio pessoal e social ${ }^{12}$, conforme esta fala do duque esclarece: "A alma do vilão embriagou-se com a posse de uma duquesa; quis fazer alarde de seus amores, quis escarnecer de mim... enganou-se!"13. D. Jaime não tolera a desobediência à hierarquia cometida pelo jovem Alcoforado.

Outra análise perspicaz do teatro de Gonçalves Dias é a de Marlene de Castro Correia na introdução da edição Teatro Completo $^{14}$ do autor. Para Correia, as quatro peças de G. Dias apresentam o mesmo tema, a estrutura do poder patriarcal. O conflito nuclear de todas as peças adviria da frustração amorosa das personagens femininas, as quais são impedidas de controlar o próprio destino. O domínio masculino seria mais evidenciado em Beatriz Cenci, Leonor de Mendonça e Boabdil, enquanto em Patkull o arbítrio patriarcal apareceria mais diluído. Outra observação importante desse estudo é que, embora os acontecimentos dos dramas gonçalvinos estejam temporalmente distantes - o assassinato de Leonor foi no ano de 1512 -, o tópico da situação de opressão das mulheres era uma questão presente e bastante debatida no século XIX. Nesse sentido, basta lembrar os exemplos de Antony e Chatterton, cujas tramas envolvem a questão da luta da mulher contra a sociedade. Esses dramas franceses,

\footnotetext{
${ }^{10}$ Mario Cacciaglia afirma que os dramas de Gonçalves Dias destacam-se no modesto panorama do teatro romântico brasileiro. CACCIAGLIA, Mario. Pequena história do teatro no Brasil: quatro séculos do teatro no Brasil. São Paulo: T.A. Queiroz; EDUSP, p. 48.

${ }^{11}$ VERÍSSIMO, José. Op. Cit., p. 183.

12 PRADO, Décio de Almeida. O drama romântico brasileiro. São Paulo: Perspectiva, 1996, p. 108-117.

13 DIAS, Gonçalves. Leonor de Mendonça. In: BUENO, Alexei (Org.). Gonçalves Dias: poesia e prosa completas. Rio de Janeiro: Nova Aguilar, 1998, p. 963.

${ }^{14}$ CORREIA, Marlene de Castro. O teatro de Gonçalves Dias. In: DIAS, Antônio Gonçalves. Teatro Completo. Rio de Janeiro: Serviço Nacional de Teatro, 1979.
} 
provavelmente, colaboraram para a concepção de Leonor de Mendonça. Observe-se que os três dramas versam sobre a luta dos fracos contra os fortes e representam a opressão dos que detêm o poder sobre os que são socialmente inferiorizados, mas "espiritualmente" superiores: Antony e Adèle, Chatterton e Kitty Bell, Antônio Alcoforado e Leonor de Mendonça.

\begin{abstract}
Si Antony et Chatterton furent deux plus grands succèss du théatre romantique, c'est que ces succèss sont fait par la même femme du siècle, la femme de trente ans, au moment où elle trouve son romancier dans Balzac; ils offrent le plus romantiquement possible a cettte femme, l'un type de l'homme fort qui défend la femme, dans son amour et dans son honneur, l'autre le type de l'homme enfant don't la femme défend le don, la grâce, le génie. Chatterton appelle la femme au combat contre la société, Antony au combat contre le 'monde'. C'étaient presque, au même théâtre, les deux versants de la même pièce. ${ }^{15}$
\end{abstract}

$\mathrm{Na}$ antologia que organizou sobre o teatro de inspiração romântica, Flávio Aguiar afirma ser Leonor de Mendonça "uma grande peça teatral dentro de qualquer parâmetro" e descreve o drama como sendo o casamento dos temas do amor cortês, da honra vingada, e do ciúme obsessivo com um intenso e ousado debate sobre a condição da mulher na sociedade patriarcal de Portugal no século XVI e do Brasil do século XIX. O crítico considera o texto do drama simples, mas salienta o estilo antigo. Ele também pondera que a ação é desenvolvida de forma sóbria e contida semelhantemente aos melhores exemplos do teatro clássico, resultando em uma obra muito original ${ }^{16}$.

Independentemente da qualidade, os estudos de Leonor de Mendonça citados são de pequena extensão, pois se tratam de capítulos ou prefácios. Dessa forma, propomos um estudo mais extenso e aprofundado da obra prima Leonor de Mendonça. A escolha dessa peça também se deveu ao prólogo que a introduz, o qual "precisaria figurar entre os mais lúcidos manifestos do teatro romântico mundial"17, ou melhor, os aspectos modernizadores da peça são discutidos pelo autor na famosa introdução, sendo, portanto, indissociável a análise da obra de seu prefácio.

Leonor de Mendonça baseia-se, segundo a advertência de Gonçalves Dias, em um capítulo da História Genealógica da Casa Real Portuguesa que trata da vida de d. Jaime, o quarto duque de Bragança: “Aqui extratarei de uma das crônicas portuguesas o

15 THIBAUDET, Albert. Histoire de la littérature française de 1879 à nos jours, Paris: Stock, 1936 apud VIGNY, Alfred. Chatterton. Paris: Librarie Larousse, s/d., p. 91.

${ }^{16}$ AGUIAR, Flávio (Org.). Antologia do Teatro Brasileiro: o teatro de inspiração romântica. São Paulo Editora SENAC São Paulo, 1998, p. 69.

17 JACOBBI, Ruggero. Op. Cit., p. 40. 
trecho a que a este acontecimento diz respeito, para os que o quiserem saber nu e simples tal qual o refere a história: ver-se-á que a segui fielmente." ${ }^{18} \mathrm{O}$ excerto transcrito pelo autor segue abaixo:

\begin{abstract}
'Foy o motivo deste injusto ciúme Antonio Alcoforado, moço fidalgo de poucos annos, que ainda não cingia espada, filho de Affonso Pires Alcoforado, que na casa do duque tinha o mesmo foro de moço fidalgo, e servia no paço do Duque, e a quem a Duqueza tinha mostrado estimar em algumas occasiões, com que argumentando-se os falsos indícios, chegaram ao ponto da mayor fatalidade. Não quis o Duque ser o executor da sua morte, e assim mandou chamar a Lopo Garcia, seu capellão, para a confessar, depois por um negro com um manchil da cozinha lhe foy cortada a cabeça. A Duqueza, que ignorava o que passava, ouvindo um grande ruido, assustada do estrondo, foy em busca de seus filhos, e sobre a cama em que eles estavão achou o Duque, e vendo-a voltou e mandou entrar o capellão para a confessar, e tendo-o feito, entrou o Duque, a quem a Duqueza animosamente perguntou porque a queria matar? E dizendo-lhe o Duque, porque lhe fora traidora, ella lhe respondeu: nem eu sou traidora, nem meu avós o forão nunca; e com outras muitas razões lhe disputou a acusação com tanta constancia, que o Duque se deu quasi por convencido, e das persuações do capellão que clamava pela sua innocencia... e sendo o executor da morte, com cinco feridas lhe tirou a cabeça. ${ }^{, 19}$
\end{abstract}

Há, realmente, entre a história retratada na Casa Genealógica Portuguesa e a peça de Dias, fidelidade no que tange à fábula, cabendo ao poeta construir os argumentos. Ambas contam o assassinato da duquesa de Bragança, Leonor de Mendonça, pelo marido d. Jaime, acusando-a de adultério. O duque também manda assassinar o moço fidalgo Antônio Alcoforado, suposto amante da duquesa.

Na peça, d. Jaime e d. Leonor vivem uma relação pautada pela urbanidade e não por amor, já que o casamento deles foi formalizado de acordo com os costumes políticos e econômicos da nobreza. Leonor de Mendonça fora obrigada a deixar a casa paterna ainda criança e ser educada pela mãe de seu futuro esposo. Por sua vez, d. Jaime foi forçado a renunciar a sua vocação religiosa. Como era parente próximo de $\mathrm{d}$. Manuel, na falta de herdeiros diretos, o duque de Bragança poderia suceder o rei. Nesse caso, d. Jaime deveria estar casado e gerar descendência para evitar problemas na sucessão do trono. O espaço da trama é Vila Viçosa, espécie de refúgio da corte, lugar onde o duque se distrai com exercícios de caça das lembranças fatídicas do passado, o assassinato do pai ${ }^{20}$ e do irmão, bem como de seu exílio na Espanha. No entanto, para

\footnotetext{
${ }^{18}$ DIAS, Gonçalves. Op. Cit., p. 968.

${ }^{19}$ Idem, ibidem.

${ }^{20}$ Historicamente, d. Jaime tinha apenas quatro anos de idade quando seu pai d. Fernando II, $3^{\circ}$ duque de Bragança, foi decapitado em Évora, pois fora acusado de conspirar contra o rei d. João I. Em seguida, d. Jaime foi levado para Castela juntamente com seus irmãos e tios, onde recebeu a proteção da rainha $d$.
} 
Leonor o lugarejo de costumes rurais não é benfazejo, pois, sem os serões da corte, ela se entedia e vai se deitar cedo, mas não consegue dormir. D. Leonor se compadece dos sofrimentos do marido, mas teme os seus ataques de cólera. Enfim, ela é condescendente, porém não pode amar o consorte, o qual não faz nenhum esforço para amá-la ou ser amado. Nessas condições, a duquesa conhece que o jovem Alcoforado sentia por ela um amor extremoso e respeitoso. A despeito do sentimento que o desvelo do jovem cavaleiro desperta nela, Leonor de Mendonça efetivamente não trai o marido. Durante uma caçada promovida pelo nobre, Alcoforado salva Leonor da morte e, como forma de agradecimento, ela lhe concede o desejo de assentir uma última entrevista, já que ele partiria para as lides na África. O encontro é descoberto e as conjunturas sugerem indícios de traição suficientes para encolerizar o duque, dando-lhe o ensejo para matar a esposa e o "amante".

É interessante notar que Gonçalves Dias, além do fato principal narrado na crônica, aproveita-se de outras informações, como a presença dos filhos de d. Leonor no contexto do assassinato e a figura do capelão confessor, Lopo Garcia, que fora chamado por d. Jaime para fazer confessar a esposa. Na peça, esses detalhes são bem empregados, pois eles servem como argumento para que Leonor de Mendonça tente comprovar a sua inocência e suscite a piedade do leitor/espectador. A inculpabilidade da duquesa asseverada pelo padre confessor, o qual revela a confissão de Leonor ao duque na tentativa de persuadi-lo a mudar de ideia, e a declaração de amor da nobre ao jovem cavaleiro, amor que ela tenta definir como maternal e compassivo diante do leito dos filhos, são formas que a duquesa de Bragança encontra para preservar a sua imagem: “LOPO GARCIA - Bem sei que o segredo da confissão é inviolável e sagrado; porém, Deus me perdoará se obro mal com isto, porque o faço para vos poupar um crime. Sr. Duque, a vossa esposa é inocente!" 21

\footnotetext{
A DUQUESA-Sim, meus filhos. E à cabeceira de meus filhos que eu vos direi que vos amo; eu vos amo, porque sois bom, porque sois nobre, porque sois generoso; eu vos amo, porque tendes um braço forte, um coração extremoso, uma alma inocente; eu vos amo, porque vos devo a vida, porque não tendes mãe, e eu vos quero servir de mãe porque sofreis, e eu quero ser
}

Isabel. Somente no reinado de d. Manuel, em 1497, ele pode voltar a Portugal. Como o filho primogênito do $3^{\circ}$ duque de Bragança, d. Filipe, falecera, d. Jaime ficou com o título de $4^{\circ}$ duque de Bragança. D. Manuel o nomeou fronteiro-mor de todas as terras que a casa de Bragança possuía e em 1500 declarou nulos os efeitos do processo criminal do duque d. Fernando. SOUSA, D. Antonio Caetano de. História genealógica da Casa Real Portugueza. Tomo V, Lisboa: Officina Sylviana, 1738, p. 467 e ss.

${ }^{21}$ DIAS, Gonçalves. Op. Cit., p. 962-963. 
vossa irmã. É um amor compassivo e desvelado, que poderá ser reprovado na terra, mas eu não creio que o seja no céu. Entendeis-me agora?22

Na peça são incluídas outras personagens como o velho Alcoforado, Manuel e Laura - respectivamente o pai e os irmãos do jovem Alcoforado - Paula, a camarista da duquesa e Fernão Velho, o veador do duque. Os criados são importantes para a tessitura da intriga que culminará no assassinato do moço fidalgo e da duquesa de Bragança. Paula, a camarista da nobre, facilitará os encontros entre Leonor e o jovem. Fernão, servo fiel, revelará a d. Jaime o encontro noturno entre a duquesa e o moço ascendente a cavaleiro. O compromisso fora descoberto através de uma carta que o pajem da nobre senhora portava ${ }^{23}$. Já os caracteres pertencentes à família de Alcoforado, citados acima, são pertinentes para provocar um contraponto entre as duas casas, a do nobre e a do vassalo, que simbolizará, na verdade, a oposição entre os princípios da nobreza e a moral burguesa. No palácio do duque as relações seriam pautadas pelo código de honra da nobreza, o qual se caracterizaria pela urbanidade, honra e artificialidade, enquanto na casa de Manuel Alcoforado o sentimento de amor rege as relações familiares. Do ponto de vista estético, a cena na casa do pai de Alcoforado implica a inclusão de personagens cômicos (de estrato social mais baixo) num contexto sério.

Além da inclusão dessas personagens, Gonçalves Dias acrescenta um fato importante que será o propulsor do infortúnio, a já citada caçada na devassa de Vilaboim. O duque, assombrado pelas lembranças de seu passado, decide caçar a fim de esquecer as tristes recordações como a execução de seu pai, d. Fernando II. Durante a caçada, o cavalo de Leonor se assusta com um grande javali e a lança em direção ao solo. Alcoforado a enlaça nos braços e a salva do perigo, acertando o javali com o seu venábulo. $\mathrm{Na}$ esteira do amor cortês ${ }^{24}$, a bravura do jovem cavaleiro mereceu um favor da nobre senhora, a funesta entrevista noturna, que seria, aliás, um encontro de

${ }^{22}$ Idem, ibidem, p. 950-952.

23 Vale lembrar que a atribuição do papel de criados como confidentes dos protagonistas é uma característica do teatro neoclássico. MATTOS, Franklin de. Enorme, bárbaro, selvagem: Diderot e o drama. In: DIDEROT, Denis. Discurso sobre a poesia dramática. 2. ed., Trad., org., apresentação e notas Franklin de Mattos, São Paulo: Cosac Naify, 2005, p. 26. Além de manter a dinâmica que havia entre o ator e o coro no teatro grego, os diálogos entre o nobre e o criado confidente permitem a inserção da confissão de sentimentos privados, da representação da relação entre a realidade privada e a possibilidade pública, e da intriga no contexto político das sociedades aristocráticas. WILLIAMS, Raymond. Formas. In: WILLIAMS, Raymond. Cultura. Rio de Janeiro: Paz e Terra, 1992, p. 152.

24 “Transposição do esquema social criado pelo feudalismo, o amor se tornou um 'serviço' (culto) prestado pelo trovador à sua dama, como o compromisso que se estabelecia entre o senhor e o vassalo. Os amantes se comportam diante do amor, como um vassalo diante do seu suserano. Existe um serviço de amor como existe um serviço de cavalaria. O amante se torna um home-lige da pessoa amada, ou mesmo do amor personificado; cumpre suas vontades, obedece a suas ordens, executa seus menores caprichos." SPINA, Segismundo. Amor. In: A Lírica Trovadoresca. São Paulo: Edusp, 1996, p. 363. 
despedida, pois já estava acertado que o rapaz partiria para África na comitiva de d. Manuel, rei de Portugal.

Por fim, é necessário pontuar a inclusão das cenas na casa do velho Alcoforado em que o mancebo despede-se de sua família antes do último encontro com a duquesa. Esse Quadro, de acordo com o Prólogo da peça, é bastante caro ao autor, pois nele, com a apresentação de uma cena de vida doméstica, há quebra da gravidade trágica ajudando-o a perfazer um drama e não uma tragédia. Para justificar essa inserção, Dias dá um exemplo desse recurso em Victor Hugo:

\begin{abstract}
Hoje, porém, a comédia e a tragédia fundiram-se numa só criação. E de feito, se atentamente examinarmos as produções de hoje, que chamamos dramas, notaremos que ainda nas mais líricas e majestosas há de vez em quando certa quebra de gravidade, sem a qual não há tragédia. Notaremos também que essa quebra provém de ordinário de uma cena da vida doméstica, o que verdadeiramente pertence à comédia. Aquela cena, por exemplo, do segundo ato de Lucrécia Bórgia, entre Lucrécia e o duque de Ferrara, é um bosquejo da vida íntima, é um fato que, mais ou menos modificado, tem lugar em toda parte no aconchego da família; é uma cena que pertence à comédia, porque não é da sua essência fazer rir. Descreva ela fielmente os costumes, e a arte ficará satisfeita. ${ }^{25}$
\end{abstract}

Além disso, as cenas se passam em outro local que não o palácio do duque. Ainda que a casa do velho Alcoforado faça parte da propriedade de d. Jaime, pode-se inferir que Gonçalves Dias procura violar a unidade de espaço, já que há um contraponto importante entre os dois lugares. O palácio ducal simboliza o poder da alta nobreza e a casa de Alcoforado, uma família sem representação social.

Décio de Almeida Prado destaca que a história de Leonor de Mendonça e Antônio Alcoforado havia sido descrita em um periódico português, a Revista Literária, em $1838^{26}$. Advertimos que, nesse mesmo ano, a história da duquesa foi publicada em outra revista lusitana, O Panorama ${ }^{27}$. É provável que esse texto tenha servido de inspiração para Gonçalves Dias, pois os comentários em O Panorama - cuja autoria não é especificada - no sentido de haver dúvida sobre a culpa da duquesa condizem com a versão dada pelo dramaturgo brasileiro. Além disso, vale lembrar que Dias já estava em

\footnotetext{
${ }^{25}$ DIAS, Gonçalves. Prólogo a Leonor de Mendonça. In: Op. Cit., p. 907.

${ }^{26}$ Em artigo recentemente publicado, Âreas assevera que Gonçalves Dias teria se inspirado em um curto romance histórico em versos publicado na Revista Literária intitulado "A Duquesa de Bragança". ARÊAS, Vilma. Variações do "amor cortês" em Leonor de Mendonça e em O casamento de Fígaro. Teresa revista de Literatura Brasileira. Universidade de São Paulo, São Paulo: Ed. 34, n. 12-13, 2013, p. 228.

${ }^{27}$ O PANORAMA: Jornal Litterario e Instructivo da Sociedade Propagadora dos Conhecimentos Uteis. Quadros da Historia Portuguesa VII: Morte de D. Leonor Duqueza de Bragança (1512), vol. II, jan. a dez. de 1838, Lisboa: Typographia da Sociedade, 1838, p. 282-284.
} 
Portugal nesse ano, lá permanecendo até 1845 , o que pode ter facilitado o contato com a referida revista.

Essa impressão que Gonçalves Dias estava perto do centro da atualidade europeia aumenta se lembrarmos que duas peças de sua autoria foram antecedidas de pouco por crônicas saídas em revistas portuguesas: a primeira, Beatriz Cenci, em $O$ Correio das Damas, a $1^{\circ}$ e 15 de novembro de 1837; a segunda Leonor de Bragança (o título nobiliárquico de Leonor de Mendonça) na Revista Literária, tomo primeiro, em 1838. Ano este em que, por coincidência, Gonçalves Dias chega a Coimbra. Não que se devam considerar tais crônicas, só por isso, fontes diretas das peças brasileiras. Mas não há dúvida que elas reforçam as afinidades existentes entre o poeta brasileiro e os assuntos do momento. ${ }^{28}$

Como o próprio subtítulo da revista aclara - Jornal Literário e Instrutivo da Sociedade Propagadora dos Conhecimentos Úteis -, O Panorama era um veículo de uma associação de literatos que tinha como objetivo promover a instrução. $\mathrm{O}$ estilo enciclopédico foi baseado em modelos estrangeiros, como o Penny Magazine e Le Musée des Familles, visando tornar o conhecimento mais acessível para a sociedade. Abarcando ideias iluministas e temáticas românticas, o periódico abrangia informações sobre história, arqueologia, biologia, filosofia, higiene, música, tecnologia, agricultura, história natural, instrução e educação públicas, economia, belas artes, e literatura propriamente dita, entre outros objetos considerados importantes. Além disso, a revista reservava um espaço, embora menor, para artigos recreativos sobre diferentes temas, como etnologia, lendas populares, literatura de viagem, economia doméstica etc. No campo Quadros da História de Portugal ${ }^{29}$ privilegiava-se a Idade Média: as grandes figuras nacionais, os monumentos, as batalhas de fronteira, as instituições civis e

${ }^{28}$ PRADO, Décio de Almeida. Op. Cit., 1996, p. 93.

29 A partir de 1840 o Jornal manifesta a sua preferência por artigos de cunho histórico. Com a série Archeologia Portugueza, cujo objetivo era a publicação de documentos raros, O Panorama buscava atingir dois tipos de leitores: a população em geral e os eruditos interessados em fontes inéditas. A outra série de divulgação da história intitulada "Quadros da História Portugueza" mormente apresentava episódios históricos por meio de narrativas pormenorizadas. Embora trate apenas da Archeologia Portugueza, o objetivo de todas as publicações de difundir o saber histórico e favorecer o sentimento nacionalista pode ser inferido no trecho a seguir: "Um jornal popular é por todas as rasões o repositorio mais acommodado para enthesourar essas riquezas históricas. Um livro requer grande copia de materiaes nas mãos do obreiro que commette essa obra, requer certa disposição e methodo para o qual poetas nem sempre são mui próprios, por isso raros poderiam fazer sobre isso um livro com intuito artístico, que ao mesmo tempo fosse uma boa obra archeologica. Por outra parte o commum dos leitores - os mesmos que hão de ler o poema ou o romance, e assistir á representação do drama, se habituarão ao trato e freqüência dos costumes e idéas que essas composições resuscitam: as crenças, as opiniões, a vida material dos tempos passados deixarão pouco e pouco de ser para elles como estranhas, e as obras d'arte seram intelligiveis e populares, o que aliás difficultosamente aconteceria. O PANORAMA, 25 de setembro de 1841, n. 230, p. 309) apud TASCA, Michelle Fernanda. A história contada pelos periódicos: O Panorama e a História de Portugal. XXVII Simpósio Nacional de História, ANPUH, 2013, Natal. Anais... Natal: UFRN, 2013, p. 5. 
religiosas bem como as lendas e superstições desse período. O periódico também ajudou a propalar o romance histórico em Portugal, gênero que também traduz essa predileção pelo medievo.

Alexandre Herculano, por exemplo, publicou na referida revista: A Abóbada, $O$ Cronista, Arras por Foro de Espanha, O Bobo, A Dama Pé-de-Cabra, a Pedra de Arzila e o Monge de Cister ${ }^{30}$. Aliás, o autor português dirigiu O Panorama e contribuiu também com diversos artigos e traduções, os quais nem sempre foram assinados. Suas contribuições revelam a absorção das lições de autores como Michelet, Herder, e de Giambattista Vico. Seguiu Thierry, Michelet e Thiers na ideia de que o historiador pode interferir no aperfeiçoamento da sociedade e na necessidade do rigor científico no estudo da história. Além disso, o romancista português apreciava as ideias de Vico e Herder, que privilegiavam uma história da civilização, do "espírito do povo", em detrimento da simples narração das realizações efetuadas por membros da nobreza.

A história obedeceria a uma lei progressista, ou seja, o passado serviria como orientação para o futuro, não só para os representantes do povo, mas para todo o povo. Dessa forma, ficcionistas românticos optavam por buscar no passado heróis que representassem o país. Esses heróis são retirados da Idade Média, período que, segundo Herculano, sintetizaria o espírito do povo português, o qual se degradara a partir da Idade Moderna ${ }^{31}$.

[...] no estudo da história pátria cada povo vai buscar a razão dos seus costumes, a sanctidade das suas instituições, os títulos dos seus direitos; se lá vai buscar o conhecimento dos progressos da civilização nacional, as experiências lentas e custosas, que seus avós fizeram e com as quaes a sociedade se educou para chegar de frágil infância a virilidade robusta; se dessas experiências e dos exemplos domésticos, desejamos tirar ensino e sabedoria para o presente e futuro [...] Nós veremos, para adiante, como através da meia idade, principalmente no século $\mathrm{XV}$, o elemento monárchico foi gradualmente annulando os elementos aristocrático e democrático, ou, para falar com mais propriedade, os elementos feudal e municipal, annulando-os não como existências sociaes, mas como forças políticas. ${ }^{32}$

${ }^{30}$ RODRIGUES, João Bartolomeu. A educação na revista O Panorama. Tomo I. 2008. 185f. Tese (Doutorado em Educação), Universidade de Trás-os-Montes e Alto-Douro, Vila Real, 2008.

${ }^{31}$ É curioso que até mesmo na crítica aos Primeiros Cantos de Gonçalves Dias, Herculano mencione o estado de degradação de Portugal pautado numa concepção organicista da História: "Bem como a infância das nações é vivida e esperançosa; bem como a velhice humana a velhice delas é tediosa e melancólica. [...] Portugal é o velho aborrido e triste, que se volve no seu leito de decrepidez; que se lamenta de que os raios de sol se tornassem frouxos, de que se encurtassem os horizontes da esperança, de que um crepe fúnebre vele a face da terra." HERCULANO, Alexandre. Futuro Literário de Portugal e do Brasil apud DIAS, Gonçalves. Primeiros Cantos. In: Op. Cit., p. 97.

32 HERCULANO, Alexandre. Carta V: Cyclos ou grandes divisões históricas - Edade Média e Renascimento - Preferencias da edade media. In: Revista Universal Lisbonense: Jornal dos interesses physicos, morais e litterarios. Tomo II, Anno1842-1843, Lisboa: Imprensa Nacional, 1843, p. 43. 
Esse princípio de degradação de um povo que reverbera a noção herderiana de organicidade da História pode ser percebido também na obra gonçalvina ${ }^{33}$. Dias e Herculano descrevem a era das navegações portuguesas como um período de decadência em contraponto com a Idade Média e, no caso do brasileiro, com um Brasil "pré-descobrimento" 34 . Nesse sentido, é preciso atentar para o fato de que o assassinato perpetrado pelo duque em Leonor de Mendonça se passa no século XVI, durante o reinado de d. Manuel, que se caracterizou pela centralização do poder e investimento nas grandes navegações. Essas expedições foram criticadas como exemplo de degradação da índole portuguesa, ideia que pode ser vislumbrada no episódio do Velho do Restelo do Canto IV da epopeia camoniana Os Lusíadas 35 . Para Azevedo: "A corte [de d. Manuel] era verdadeiramente uma grande casa de negócio, e a geral aspiração consistia em haver parte, maior ou menor, nos lucros da Índia."36

A sugestão de que G. Dias tenha se inspirado pela leitura dessa revista romântica ${ }^{37}$ deve-se ao fato de que no Quadro de $O$ Panorama pontuam-se também os indícios da inocência da duquesa de Bragança indicando uma das fontes na qual a inculpabilidade da nobre é aludida, a saber, o $5^{\circ}$. tomo da História Genealógica, ou seja, a mesma referência indicada por Gonçalves Dias. Curiosamente, no Jornal comenta-se que o crime seria matéria propícia para a escrita de romances ou poemas.

\footnotetext{
${ }^{33}$ Para Herder a filosofia iluminista estava errada em ver as Luzes, de feição centralizadora e atemporal, como o escopo da história da humanidade. Ele propõe que a história possui uma racionalidade própria que se desenvolve por meio de uma atividade espontânea que organicamente alcança o seu fim. SUZUKI, Márcio. O Gênio Romântico: crítica e história da filosofia em Friedrich Schlegel. São Paulo: Iluminuras, 1998, p. 63; A esse processo, o filósofo associa a ideia de Volkgeist. "Segundo Herder, a evolução da humanidade se dá por fases. São os povos em sua individualidade, os fatos locais, as produções populares de cada nação (fábulas, mitos, músicas e costumes) que, ao se entrelaçarem em determinadas épocas e situações, dão forma ao progresso e injetam sentido no curso dos acontecimentos históricos" PECORARO, Rossano. Filosofia da História. Rio de Janeiro: Jorge Zahar, 2009, p. 31.

${ }^{34}$ Um exemplo para Gonçalves Dias de que a vinda dos portugueses, movidos pela ambição, profanou a civilização indígena "pré-descobrimento" pode ser inferido no poema "O canto do piaga": "Pelas ondas do mar sem limites/ Basta selva, sem folhas, i vem;/ Hartos troncos, robustos, gigantes;/ Vossas matas tais monstros contêm. [...] /Não sabeis o que o monstro procura? Não sabeis a que vem o que quer? / Vem matar vossos bravos guerreiros, vem roubar-vos a filha, a mulher! / Vem trazer-vos crueza e impiedade -/ Dons cruéis do cruel Anhangá;/Vem quebrar-vos a maça valente, /Profanar Manitôs, Maracá. /[...]" DIAS, Gonçalves. Excerto de "O canto do piaga". Primeiros Cantos. In. DIAS, Gonçalves. Op. Cit., p. 110 .

35 “- Ó glória de mandar! Ó vã cobiça/Desta vaidade a quem chamamos fama! / Ó fraudulento gosto que se atiça/Cuã aura popular que honra se chama! /Que castigo tamanho e que justiça/Fazes no peito vão que muito te ama! /Que mortes, que perigos, que tormentas, /Que crueldades neles experimentas!" CAMÕES, Luís. Os Lusíadas. Prefácio e notas Hernani Cidade. São Paulo: Círculo do Livro, s/ data, p. 178.

${ }^{36}$ AZEVEDO, J. Lúcio. Épocas de Portugal Econômico. 4. ed., Lisboa: Clássica Editora, 1978, p. 83.

37 Vale lembrar com Prado como o emprego de eventos da história de Portugal em dramas nacionais mostra a prolongação de nossa relação com a ex-metrópole. "Filhos recentemente emancipados, julgavamo-nos, ao que parece, com direito à herança histórica paterna, sobretudo na parte relativa aos feitos medievais, anteriores à descoberta do Brasil.” PRADO, Décio de Almeida. Op. Cit., 1996, p. 60-61.
} 
Historiadores gravíssimos teem procurado pôr em duvida o crime de D. Leonor: nem são para despresar os motivos que allegam em abono de sua opinião. No auto mandado fazer pelo duque, as testemunhas quem são? Clientes e creados seus. Depois de ter feito duas execuções, sem ter sido nomeado algoz d'officio, elle precisava justificar-se aos olhos d'elrei e do mundo; a duqueza estava morta: seria pois possível alevantar-se alguma voz a favor della? A rainha D. Catharina, mulher de D. João $3^{\circ}$., fazendo, passados annos, averiguações acerca deste sucesso, alcançou documentos e cartas daquella epocha, escriptos por familiares do duque, em que se affirmava que D. Leonor morrera innocente. Os escriptores que seguiram esta opinião se podem consultar no $5^{\circ}$. tomo da Historia Genealogica entre elles se conta o celebre D. Francisco Manuel de Mello. Dizem que os amores de Antonio Alcoforado eram com uma dama da duqueza, a quem esta dera certa joia que recebera do marido. Deu-a depois aquella dama a Antonio Alcoforado: viu-lha o duque; perguntou por ella a D. Leonor, a qual, temendo que o marido lhe levasse a mal o have-la dado, respondeu que a tinha a seu poder, mas exigindo D. Jayme que lh'a apresentasse o não pode fazer. Daqui nasceram os ciúmes do duque, os quaes confirmou Fernão Velho com as cartas que se dizia eram mandadas escrever pela duqueza. Seja como for, a razão ou sem-razão da morte de D. Leonor será sempre um mysterio. [...]

A tradição perpetuou na lembrança do povo o trágico sucesso de D. Leonor. Os contos populares a este respeito seriam matéria para deleitosos romances ou poemas. ${ }^{38}$

O objetivo desse tipo de publicação, mormente, era difundir o saber histórico e incutir o sentimento nacionalista. A transformação da tragédia de Leonor de Mendonça em objeto artístico, bem como de outros fatos da história de Portugal, serviria para acostumar o público com os costumes, as crenças, as opiniões, a vida material e as ideias do passado tornando-lhes conhecidas e facilitando a recepção de outras obras que versassem sobre os tempos remotos ${ }^{39}$.

Provavelmente Dias foi inspirado pela Revista mencionada, mas tinha objetivos diferentes, trabalhar o enredo histórico considerando os preceitos do drama romântico, especialmente os expostos por Victor Hugo no famoso Prefácio de Cromwell e também em prólogos de dramas como Maria Tudor, Angelo e Ruy Blás. Embora o diálogo com o drama hugoano seja preponderante, conforme veremos ao longo deste trabalho, a peça gonçalvina apresenta menor proximidade com o melodrama do que muitas obras de Victor Hugo. Isso se dá não só devido à permanência de aspectos da tragédia neoclássica na obra gonçalvina ${ }^{40}$, sobretudo no que tange ao equilíbrio, à proporção, e à

${ }^{38}$ O PANORAMA: Jornal Litterario e Instructivo da Sociedade Propagadora dos Conhecimentos Uteis. Quadros da Historia Portuguesa VII: Morte de D. Leonor Duqueza de Bragança (1512), vol. II, jan. a dez. de 1838, Lisboa: Typographia da Sociedade, 1838, p. 284.

39 Idem, 25 de setembro de 1841, n. 230, p. 309 apud TASCA, Michelle Fernanda. Op. Cit., 2013, p. 5.

40 "De acordo com Croce, em sua iniciação à Estética, o Classicismo se distingue fundamentalmente por elementos como o equilíbrio, a ordem, a harmonia, a objetividade, a ponderação, a proporção, a serenidade, a disciplina, o desenho sapiente, o caráter apolíneo, secular, lúcido e luminoso. Avesso ao 
linguagem elevada; mas também porque, se por um lado Leonor está fortemente imbuída de temáticas românticas, de outro, ela contraria o amor romântico ao fazer com que a protagonista coloque em primeiro lugar o desejo de viver e não o de consolidar o amor por meio da morte, ação que fez com que Prado aproximasse a peça do realismo flaubertiano:

\begin{abstract}
Leonor de Mendonça respira todo tempo o ar do romantismo, tanto no cavalheirismo que se põe à prova quanto na defesa apaixonada da causa feminista. Mas a simplicidade de suas linhas, desembaraçadas de ornamentos, parece remeter ao mais puro classicismo, enquanto que a sua rara capacidade de penetração psicológica e a sua tão clara percepção social fazem-nos recordar de preferência o realismo - não o realismo teatral brasileiro, carregado de moralismo, mas aquele realismo que iria triunfar, em 1857, com a publicação de Madame Bovary de Gustave Flaubert. ${ }^{41}$
\end{abstract}

Décio de Almeida Prado toma o cuidado de dizer que dois aspectos precisos em Leonor de Mendonça faz-nos apenas recordar o realismo do tipo flaubertiano, a penetração psicológica e a percepção social, pois claro está que o a escola realista diferentemente do romantismo pretendia representar o real de forma objetiva e exaustiva imprimindo à arte um caráter documental, enquanto a estética romântica propunha, contrariamente, poetizar o real partindo da visão do artista, do gênio. Vale lembrar que os autores realistas para dar conta da descrição do real construíram um estilo requintado que os afastava da objetividade almejada ${ }^{42}$. Adverte-se também que a comparação aventada não tem por escopo sobrepor a habilidade literária de Gonçalves Dias a Flaubert, mas apenas aludir, como faz Wellek ${ }^{43}$, às co-incidências que ocorrem na literatura sem que haja diálogos diretos. Essas aproximações temáticas ou estéticas podem ser vislumbradas porque num determinado contexto histórico-social ideias e sentimentos são disseminados fomentando na literatura ocidental interessantes interrelações.

elemento noturno, o Classicismo quer ser transparente e claro, racional. E com tudo isso exprime, evidentemente, uma fé profunda na harmonia universal. A natureza é concebida essencialmente em termos de razão, regida por leis, e a obra de arte reflete tal harmonia. A obra de arte é imitação da natureza e, imitando-a, imita seu concerto harmônico, sua racionalidade profunda, as leis do universo." ROSENFELD, Anatol; GUINSBURG, J. Romantismo e Classicismo. In: GUINSBURG, J. (Org.). $O$ Romantismo. São Paulo: Perspectiva, 2011, p. 262.

${ }^{41}$ PRADO, Décio de Almeida. Op. Cit., 1996, p. 117.

${ }^{42}$ VALÉRY, Paul. A tentação de (São) Flaubert. In: FLAUBERT, Gustave. As tentações de Santo Antão. Trad. Luís de Lima, São Paulo: Iluminuras, 2004, p. 7-8.

${ }^{43}$ WELLEK, René. A crise da Literatura Comparada. In: COUTINHO, EDUARDO F; CARVALHAL, Tania Franco (Orgs.). Literatura Comparada: textos fundadores, 2. ed., Rio de Janeiro: Rocco, 2011, p. 121. 
Ao longo deste estudo, privilegia-se a comparação de Leonor de Mendonça com obras dramáticas coetâneas a fim de demonstrar como Gonçalves Dias esteve atento à produção teatral da época. Esse amálgama de diferentes confluências fez de Leonor de Mendonça uma obra prima ${ }^{44}$, ou seja, a presença de aspectos inovadores do drama romântico, tais como a mistura de gêneros e a temática social, e também a manutenção de características neoclássicas, como a clareza da linguagem e a concentração da ação, lhe foi favorável porque propiciou modernidade e efetividade dramática.

\footnotetext{
Se Gonçalves Dias é efetivamente um dos formadores ativos da ideia de uma literatura brasileira autônoma, isso se dá também por sua insistência em visitar gêneros diversos na poesia, na prosa e no drama, e por seu elaborado e erudito universalismo, que se traduz na vontade de internacionalizar e de atualizar a literatura brasileira. ${ }^{45}$
}

Como o escopo deste trabalho é analisar o drama Leonor de Mendonça privilegiando o contexto de produção da obra do ponto de vista estético, o exame da peça abrangerá um estudo sobre os gêneros dramáticos em voga no período e a relação da obra gonçalvina com essas estéticas teatrais. A ideia é perceber como os elementos do drama burguês, do melodrama, do drama histórico e romântico bem como aspectos da literatura gótica estão imbricados no texto em questão. Vale aclarar que o drama burguês, o melodrama e a literatura gótica antecipam muitos temas e características que serão frequentes na literatura do romantismo, dessa forma, a presença de elementos desses gêneros em Leonor apenas reafirma o vínculo com seus precursores. Tendo em vista essa relação, serão apresentadas as principais características desses gêneros enfatizando os predicados análogos presentes em Leonor de Mendonça. Além disso, a permanência de características neoclássicas aventada acima também será discutida ao longo dos capítulos da presente tese. O intuito não é classificar a obra gonçalvina, a qual tem sido tradicionalmente referida como drama histórico pela crítica, mas apontar como o diálogo com esses gêneros colabora para a construção do drama. O estudo do Prólogo visa complementar e aclarar essa relação entre a estética romântica e o fazer dramático de Gonçalves Dias. Por fim, a apreciação de Leonor de Mendonça considerará o

\footnotetext{
44 “Tanto Beatriz Cenci (1843) quanto Leonor de Mendonça (1846) foram antecedidas por crônicas saídas em revistas portuguesas da época, o que mostra o poeta atento aos interesses de seu tempo. Além disso, as referências a grandes dramaturgos, a leitura de Chatterton, de Alfred de Vigny, enquanto escrevia seu drama, a tradução de $A$ Noiva de Messina, de Schiller, feita por ele, tudo isso fez de nosso poeta um conhecedor do palco, com informação diferenciada em nosso meio.” ARÊAS, Vilma. Op. Cit., 2013, p. 232.

45 WERKEMA, Andréa Sirihal. Macário, ou o do drama romântico em Álvares de Azevedo. Belo Horizonte: UFMG, 2012, p. 166.
} 
panorama teatral brasileiro na primeira metade do século XIX a fim de aprofundar a análise. Em suma, pretende-se com a presente tese contribuir para o estudo do teatro de Gonçalves Dias e a pesquisa sobre o Romantismo no Brasil. 


\section{O PRÓLOGO}

Leonor de Mendonça deve seu renome não apenas à complexidade e ao rigor artístico da peça, mas também ao prólogo que a precede. Conforme já observado, Jacobbi julga-o um dos melhores exemplos de clareza na exposição de conceitos do teatro romântico. José Veríssimo em sua História da Literatura Brasileira faz um breve comentário sobre o prólogo em questão afirmando que, apesar dos "inevitáveis sacrifícios à poética do tempo", ele apresenta conceitos inteligentes e originais. A interpretação dada ao fato histórico (Leonor inocente e assassinada) tornou o drama original, psicologicamente verdadeiro, humano e dramático. Ainda segundo Veríssimo, isso se dá graças à noção de fatalidade das circunstâncias sociais, esboçada "chãmente" por Gonçalves Dias, novidade invulgar para a época ${ }^{46}$.

Décio de Almeida Prado filia o "rico e lúcido" prólogo gonçalvino aos típicos prefácios da geração romântica que buscavam justificar as inovações de suas obras. Além disso, ele observa que parte do prólogo de Leonor de Mendonça serve para criticar o órgão governamental Conservatório Dramático por exercer a censura moral e política ao invés de promover a arte e a crítica literária. A posição de G. Dias é clara e não tem um viés pessoal ou ofensivo. Para o dramaturgo a liberdade de criação e a crítica impulsionariam a produção literária brasileira. Ele defende a liberdade não só de publicação, mas também de representação das obras teatrais, cabendo ao Conservatório exercer a crítica teatral conforme o modelo dos folhetins de Martins Pena publicados no Jornal do Comércio do Rio de Janeiro em 1846, "A Semana Lírica”:

\footnotetext{
Em artigos sem assinatura, mas que todos sabiam ser de sua autoria, Martins Pena discorria com a maior segurança sobre as peças apresentadas, o desempenho dos intérpretes, o mérito da orquestra, a afinação dos instrumentos, a propriedade dos cenários e do guarda-roupa, o brilho dos regentes, ou sobre as falhas existentes em cada um desses setores. Pode-se afirmar que foi ele, na verdade, o criador da crítica musical, em grande estilo, em nosso país. ${ }^{47}$
}

\footnotetext{
${ }^{46}$ VERÍSSIMO, José. Op. Cit., p. 183.

${ }^{47}$ MAGAlHÃES JR., R. Martins Pena e sua época. 2. ed. São Paulo: LISA; Rio de Janeiro: INL, 1972, p. 191 apud GIMENEZ, Priscila. Martins Pena: crítico-folhetinista. XI Congresso Internacional da ABRALIC: Tessituras, Interações, Convergências. Anais eletrônicos. São Paulo: USP, 2008. Disponível em://www.abralic.org.br/anais/cong2008/AnaisOnline/simposios/pdf/075/PRISCILA_GIMENEZ.pdf. Acesso em: 04 mar. 2013.
} 
Prado também chama atenção para os "pontos de vista teóricos" que o prefácio de Leonor de Mendonça expõe. Gonçalves Dias vale-se da definição de drama proposta no Prefácio de Cromwell de Victor Hugo, no qual ele é definido como a junção da comédia e da tragédia incluindo personagens burguesas e cenas domésticas num enredo sério. Para Prado, embora não seja bem explicitada por Dias, a concepção de drama adotada, a combinação da tragédia e da comédia, tem como consequência as cenas domésticas na casa do velho Alcoforado. Nelas são inseridas personagens que antes seriam próprias do âmbito da comédia, opondo-se ao teor grave que o trágico impõe ao tratar de ações nobres vinculadas à esfera pública. A reconfiguração do gênero cômico em Leonor de Mendonça se dá por meio da elevação das personagens da família de Alcoforado, que pertencem a um estrato social mais baixo, por meio da valorização de suas ações, as quais não causam, de modo algum, o riso. Em seguida, no Prólogo, o dramaturgo expõe a preferência pelo uso simultâneo do verso e da prosa, de acordo com o sentido e o efeito das falas.

Para João Roberto Faria ${ }^{48}$, a leitura das peças e do "belíssimo" prólogo de Leonor de Mendonça revela que Gonçalves Dias foi o primeiro dramaturgo brasileiro a compreender e aceitar a estética teatral romântica. Em seguida, o estudioso analisa a peça em questão, baseando-se nos pressupostos de Dias esboçados no dito prólogo. Um dos aspectos comentados por Faria foi a opção de Gonçalves Dias por fazer sua Leonor inocente e castigada, vítima de uma fatalidade que o autor do drama classifica como circunstancial. Essa alternativa em detrimento de um modelo mais maniqueísta, popular e melodramático enriqueceu a psicologia das personagens. A "fatalidade circunstancial" introduzida nesse drama refere-se, segundo o crítico, à condição da mulher numa sociedade patriarcal e também ao casamento imposto, que impediu o duque de seguir a sua vocação religiosa. Faria também destaca as considerações que G. Dias faz sobre o paralelo entre d. Jaime e Otelo. A semelhança primordial entre as duas personagens seria o cometimento de assassinato impulsionado por indícios de adultério. Já a diferença essencial seria que Otelo ama Desdêmona, e d. Jaime não ama sua esposa. Por isso, a vingança daquele caminha a passos lentos, enquanto este age precipitadamente e movido pelo orgulho. O crítico conclui que essa comparação comentada por Dias demonstra que em meados de 1840 já era conhecida a obra original de Shakespeare, e não mais apenas a versão classicizante de Ducis anteriormente difundida no Brasil.

\footnotetext{
${ }^{48}$ FARIA, João Roberto. Op. Cit., 2001, p. 44-49.
} 
Chama atenção do estudioso também a clareza com que Dias resume a ação dramática da peça: 'Prender a todos uns aos outros com o amor ou com a obediência, ligá-los estreitamente entre si, juntá-los, impelir um sobre os outros, e fazer brotar a dor e a poesia do choque de todas essas almas, e do choque das paixões o drama'. Dando sequência ao seu comentário, o pesquisador aborda a estética do drama esboçada pelo dramaturgo brasileiro. Gonçalves Dias se mostra alinhado com a teoria exposta por Victor Hugo no "Prefácio de Cromwell" sobre a fusão da tragédia e da comédia. O crítico teatral também comenta o tema da linguagem discutido por Dias sobre a preferência em imitar Shakespeare e utilizar o verso e a prosa afastando-se das orientações de Victor Hugo. No entanto, como o dramaturgo brasileiro sabia que o drama deveria ser apreciado pelo Conservatório Dramático, optou, por fim, pelo uso da prosa. Em relação às reparações feitas às arbitrariedades do Conservatório no Prefácio ${ }^{49}$, Faria adverte que se o Prólogo de Leonor de Mendonça foi realmente escrito em setembro de 1846, e a proibição da representação do drama Beatriz Cenci é de novembro de 1846 - conforme atestam o Panteon Maranhense de Antonio Henriques Leal e as pesquisas de M. Nogueira da Silva e Lúcia Miguel Pereira-, as observações sobre a instituição feitas por Dias seriam uma análise refletida sobre o verdadeiro papel do Conservatório Dramático, e não uma retaliação à censura imposta à sua Beatriz como se propagou.

Sábato Magaldi ${ }^{50}$ também julga o prólogo gonçalvino excelente e "uma das páginas mais lúcidas e penetrantes de estética na nossa literatura". Ele ressalta a questão, em Leonor de Mendonça, sobre a sujeição das mulheres e a relação entre as personagens tratadas por Dias sob o viés da fatalidade, "filha dos nossos hábitos" de civilização que resultou em uma perspicaz e profunda sondagem social. Dessa forma, Magaldi exalta a consciência histórica do dramaturgo. Sobre o prefácio gonçalvino, o crítico destaca ainda o trecho em que o poeta menciona o abismo entre a obra delineada e a obra já feita, e comenta que essa distância aparece nas outras peças do autor, excetuando Leonor de Mendonça que, como o prólogo evidencia, é um produto de "reflexão ponderada". Finalmente, Sábato Magaldi interpreta que Dias "aceitou que o

\footnotetext{
49 “O drama é feito para ser representado, e entre nós podem ser representados os que forem aprovados pela censura competente; de maneira que o nosso Conservatório Dramático na Corte, e um delegado e um subdelegado de polícia nas províncias, tem um veto onipotente contra o qual na há recurso, ou eu não o conheço. Quem nos dirá que na primeira folha do malfadado manuscrito não gravaria o Conservatório Dramático o seu veto? O veto é tanto mais fácil de ser exarado, que a lei não exige o porquê ..." DIAS, Gonçalves. Prólogo de Leonor de Mendonça. Op. Cit., p. 910.

${ }^{50}$ MAGALDI, Sábato. Op. Cit., p. 71-74.
} 
drama resumisse a comédia e a tragédia" e lembra a opção do dramaturgo pelo uso da prosa, imaginando que a inovação do uso da prosa e do verso seria preterida pelo Conservatório, embora pensasse que o melhor seria o uso dos dois registros.

Correia $^{51}$ assevera que o Prólogo demonstra quão consciente estava G. Dias de que sua obra se afastava dos padrões melodramáticos, os quais dominavam o teatro brasileiro. Segundo a estudiosa, a própria epígrafe do Prólogo: "Contentar a todos ninguém o alcançou, muitos se contentaram em aprazer a muitos. $\mathrm{O}$ autor tomará por grande honra satisfazer a poucos." ${ }^{, 52}$, não seria um reflexo de retórica romântica, no sentido de ser apenas uma simples forma de expressão cristalizada, mas a proclamação dessa independência em relação ao gosto predominante. Para ela, a escolha de Dias pela "verdade histórica" (Leonor inocente e assassinada) em detrimento da verdade moral deve-se à aproximação que o autor fazia entre enredo melodramático e facilidade dramática. Dito de outra maneira, Gonçalves Dias teria optado por fazer algo mais complexo do que a moralidade melodramática de cunho maniqueísta e os enredos recheados de surpresas e sobressaltos para agradar o público prescreviam ${ }^{53}$.

Feito um breve apanhado da fortuna crítica, para uma melhor compreensão da importância do Prólogo é necessário atentar para as características precípuas desse tipo de texto, especialmente seu caráter paratextual e seu cunho funcional. Segundo Genette, o paratexto não só estabelece a presença, a recepção e o consumo do livro, mas também age de forma estratégica para que haja melhor acolhida por parte do público, dirigindo-o no sentido de aceitar a obra em questão e de obter uma leitura mais pertinente ${ }^{54}$. Os prólogos respondem a uma necessidade de circunstância. Considere-se, por exemplo, o caso de uma introdução original, feita para a primeira edição da obra, e de outra organizada para uma coletânea. Eles também se diferenciam de acordo com o tipo de

\footnotetext{
${ }^{51}$ CORREIA, Marlene de Castro. Op. Cit., s/p.

${ }^{52}$ DIAS, Gonçalves. Prólogo a Leonor de Mendonça. Op. Cit., p. 903.

${ }^{53}$ A interpretação de Correia baseia-se no seguinte trecho do Prólogo: "A ação do drama é a morte de Leonor de Mendonça por seu marido: dizem os escritores do tempo que D. Jaime, induzido por falsas aparências, matou sua mulher; dizem, porém, de tal maneira, que facilmente conjeturar que não foram tão falsas as aparências como eles no-las indicam. O autor podia então escolher a verdade moral ou a verdade histórica - Leonor de Mendonça culpada e condenada, ou Leonor de Mendonça inocente e assassinada -. Certo que a primeira oferecia mais interesse para a cena e mais moral para o drama; a paixão deveria então ser forte, tempestuosa e frenética, porque fora do dever não há limite nas ações dos homens: haveria cansaço e abatimento no amor e reações violentas para o crime, haveria uma luta tenaz e contínua entre o sentimento da mulher e os da esposa, entre a mãe e a amante, entre o dever e a paixão: no fim estaria o remorso e o castigo, e neles a moral. Há nisto matéria para mais de um bom drama." DIAS, Gonçalves. Prólogo a Leonor de Mendonça. Op. Cit., p. 904.

54 “... paratexto é aquilo por meio de que um texto se torna livro e se propõe como tal a seus leitores, e de maneira mais geral ao público". GENETTE, Gérard. Paratextos Editoriais. Trad. Álvaro Faleiros. Cotia, SP: Ateliê Editorial, 2009, p. 9-10.
} 
autoria: o escritor real pode se responsabilizar pelo prefácio, criar um autor fictício ou ainda relegar a tarefa a outrem.

$\mathrm{O}$ texto gonçalvino em questão trata-se de um prólogo autoral, autêntico e assuntivo, isto é, o próprio autor escreve e se responsabiliza pela introdução a fim de expor por que e como o leitor deve ler a sua obra. Nos prefácios em geral, é comum que o assunto seja legitimado por meio da exposição de sua importância e que o escritor assevere a sua falta de habilidade para abordar tal temática. Dito de outra forma, os autores tendem a destacar a utilidade e a necessidade de exploração do tema presente em sua obra e a sua incapacidade para tratá-lo. No caso de Leonor de Mendonça, conforme se verá por meio da análise do prefácio, Gonçalves Dias optou por apontar as suas intenções, ${ }^{55}$ descrevendo o processo estético e sugerindo a ideia da utilidade social do teatro ${ }^{56}$.

Vale ressaltar ainda duas noções apontadas por Genette a respeito do prólogo autoral que também aparecem na introdução de Dias, a de que ao evidenciar a sua intenção, o autor evita os juízos mal-entendidos e mal-intencionados, os quais podem influenciar a recepção da obra; e que há sempre uma desproporção entre o que se planejou dizer e o resultado, entre o pensamento e a expressão, recurso que não deixa de ser retórico, uma forma de captatio benevolentiae. Outro atributo comentado por Genette sobre os prefácios, inerente ao trabalho do dramaturgo brasileiro, é a preocupação com as definições, no caso, do gênero drama. Isso se dá porque a obra de Gonçalves Dias encontra-se numa época de transição em que as regras teatrais neoclássicas continuavam em vigor e os desvios dessas normas, como a linguagem prosaica e a introdução de elementos cômicos em enredos com desfecho trágico, precisavam ser esclarecidos ${ }^{57}$.

O Prólogo a Leonor de Mendonça reafirma a preocupação com o fazer artístico que se manifesta na obra gonçalvina em seus prólogos e metapoemas, tais como "A

\footnotetext{
55 “A mais importante, talvez, das funções do prefácio original consiste numa interpretação do texto pelo autor, ou, se se preferir, numa declaração de intenção. Semelhante abordagem é aparentemente contrária a certa vulgata moderna, formulada em particular por Valéry, e que recusa ao autor qualquer controle sobre o 'verdadeiro sentido', ou mesmo que nega absolutamente a existência de semelhante sentido". Idem, ibidem, p. 196.

${ }^{56}$ Essa opção colabora para confirmar a afirmação de Faria de que o dramaturgo brasileiro privilegiava o teatro romântico, sobretudo as produções de Victor Hugo e, por isso, conscientemente valoriza o aspecto social de sua peça em prejuízo da utilidade moral, a qual o aproximaria tanto do teatro neoclássico como do melodramático. Exemplo claro da preocupação com a moralidade é apresentado no prefácio de Racine para Fedra: 'Não fiz [tragédia] onde a virtude seja mais posta às claras do que nesta. Nela os menores erros são punidos severamente, [...] É esse propriamente o objetivo que todo homem de bem que trabalha para o público se deve propor.' apud GENETTE, Gérard, Op. Cit., p. 178.

${ }^{57}$ GENETTE, Gérard, ibidem, p. 199.
} 
minha musa" (Primeiros Cantos), "O vate" (Primeiros Cantos) e "Canção" (Segundos Cantos). Nesses textos estão sempre presentes a inquietação teórico-estética "sobre o modelo de composição e seus objetos temáticos" e a certeza de que o ato de produzir é oriundo da inspiração, da subjetividade e da renovação estilística ${ }^{58}$.

"A minha musa" assinala a ruptura com a perspectiva neoclássica e afirma a postura subjetiva de suas poesias. Mostrando-se em desacordo com o mundo, o poeta busca a solidão, o silêncio, a natureza e, em última instância, a morte. Assim, a sua poesia não pode ser prazenteira, mas triste e sentimental. "Canção" refere-se à subdivisão de sua poesia: aos hinos, à lírica amorosa e ao indianismo/medievalismo. Esses temas são cantados utilizando diferentes instrumentos, ou seja, o poeta reflete sobre a relação entre forma e conteúdo ressaltando também o diálogo com a tradição.

Em "O Vate", Dias procura esclarecer qual seria a função do vate, definindo-a por meio da ideia de missão, juízo que se apoia nas proposições de Victor Hugo. O diálogo com o poeta francês pode ser inferido a partir da epígrafe. A fala de Jeová no poema de Dias remete à ideia hugoana de que o cristianismo separa espírito e matéria criando um abismo entre a humanidade e Deus, introduzindo o sentimento de melancolia entre os homens. A religião cristã traz alento, "uma religião de igualdade, de liberdade, de caridade" 59 , diante das profundas transformações que o mundo sofreu. Vale lembrar que essa perspectiva historicista em Hugo mostra a necessidade de mudanças na arte: "Eis, pois, uma nova religião, uma sociedade nova; sobre esta dupla base, é preciso que vejamos crescer uma nova poesia." $" 60$

O poeta francês e Gonçalves Dias pontuam as transformações poéticas em consonância com os contextos históricos confrontando as odes bíblicas e as epopeias gregas aos "poetas modernos" como Shakespeare (em Hugo), Dante e Milton (em Dias). Para eles, a separação entre os homens e Deus impõe ao poeta a missão de interventor na tentativa de reaproximar a matéria da alma, reunindo os contrários. O prefácio de Hugo a Cromwell se inicia por um exame do desenvolvimento da literatura em relação com o da história, propondo, por meio dessa análise, uma ideia de como se compõe a sensibilidade moderna. Assim como a humanidade passou por três idades: a infância, a idade adulta e a velhice; a poesia conhece três estapas essenciais que se coadunam a

\footnotetext{
${ }^{58}$ ARAÚJO, Jorge de Souza. Gonçalves Dias: a clave e a clava. In: Retrós de espelhos: o romantismo brasileiro com lentes de aumento. Ilhéus, BA: Editus, 2011, p. 119-120.

${ }^{59}$ HUGO, Victor. Do grotesco e do sublime: tradução do Prefácio de Cromwell. Trad. Célia Berrettini. São Paulo: 2004, p. 24

${ }^{60}$ Idem, ibidem, p. 26.
} 
uma forma de expressão: “- os tempos primitivos, com o lirismo, - os tempos antigos, com a epopeia, - os tempos modernos, com o drama"

Gonçalves Dias dialogando com Victor Hugo define o que foi e o que é o poeta vate: sacerdote revelador dos vaticínios divinos; intercessor em favor dos homens, mesmo dos réprobos; criador, por meio da palavra ${ }^{62}$, triste exilado em sua missão de maldizer os vícios e solidarizar com os infelizes. Assim, também é possível vislumbrar certo pragmatismo literário na acepção de Dias. A ação do poeta toma uma feição mais objetiva, embora ele a relacione à religião cristã que não assume uma significação apenas religiosa, mas os sentidos estéticos trabalhados por Hugo no Prefácio de Cromwell. A propósito, segundo Antônio Candido, a figura idealizada do escritor romântico está associada à ideia de missão, seja ela de caráter espiritual ou social. Vale ressaltar que essa idealização desgastou-se e foi empregada muitas vezes apenas como um lugar comum ou assumiu um caráter pragmático que dissociou da poesia a aura profética:

\begin{abstract}
A contribuição típica do Romantismo para a caracterização literária do escritor é o conceito de missão. Os poetas se sentiram sempre, mais numas fases que noutras, portadores de verdades ou sentimentos superiores aos dos outros homens: daí o furor poético, a inspiração divina, o transe, alegados como fonte de poesia. Nas épocas de equilíbrio, como o Neoclassicismo, estas interpretações funcionam como simples recurso estético, requeridas em certas formas, como o ditirambo. Francisco José Freire, por exemplo, afirma que o furor poético nada tem de extraordinário; é um estado da consciência, não algo superior que descesse sobre ela. $\mathrm{O}$ poeta romântico não apenas retoma em grande estilo as explicações transcendentes do mecanismo da criação, como lhes acrescenta a ideia de que a sua atividade corresponde a uma missão de beleza, ou de justiça, graças à qual participa duma certa categoria de divindade. Missão puramente espiritual para uns, missão social, para outros - para todos, a nítida representação de um destino superior, regido por uma vocação superior. É o bardo, o profeta, o guia. ${ }^{63}$
\end{abstract}

O poeta brasileiro, como bem pontuou Marques ${ }^{64}$, quer interferir na teia de relações histórico-estéticas por meio da poesia e da subjetividade. Assim, como vimos, a definição gonçalvina de poeta moderno em "O Vate" acrescenta às predicações da

${ }^{61}$ BERRETTINI, Célia. Introdução. In: HUGO, Victor. Op. Cit., p. 8.

${ }^{62}$ No movimento pré-romântico alemão o gênio é definido como "bardo e vidente, porta-voz das esferas mais altas; mensageiro divino, herói colossal, mediador do infinito no 'medium' da finitude. Não imita a divindade e a natureza; é, antes, criador como Deus e a natureza." ROSENFELD, Anatol. Da Ilustração ao Romantismo. In: Autores pré-românticos alemães. São Paulo: EPU, 1991, p. 13.

${ }^{63}$ CANDIDO, Antonio. Formação da Literatura Brasileira: momentos decisivos (1836-1880), Vol. II, São Paulo: Livraria Martins Editora, 1964, p. 26.

${ }^{64}$ MARQUES, W. J. O poema, o prefácio e o diálogo necessário. Revista Letras. Curitiba: Editora UFPR, n. 67 , set./dez. 2005. 
tradição uma responsabilidade social, a de consolar o infeliz e enfrentar os grandes, além de maldizer a soberba, o crime e os vícios. Para Cunha, ao aferir à poesia um objetivo pragmático e adotar em sua poética o sentimentalismo como um fim em si mesmo, conferindo à expressão do sofrimento um cariz de conformação e não de conflito entre o sujeito e a sociedade, G. Dias se coadunaria com os princípios neoclássicos de poesia ${ }^{65}$.

Marques observa que em Gonçalves Dias a consciência do fazer poético é uma questão fundamental como atesta o prefácio de os Primeiros Cantos cujos tópicos abarcam temas importantes da estética romântica. Para o crítico, a "definição indefinida" desse prólogo (“- A Poesia como eu a compreendo sem a poder definir, como eu a sinto sem a poder traduzir.") reverbera o paradoxo da literatura romântica de saber ser a linguagem incapaz de expressar plenamente ideias e sentimentos. Além disso, a indefinição vai de encontro à objetividade e clareza da poesia neoclássica ${ }^{66}$. A manifestação do sentimento de isolamento do poeta no trecho:

\footnotetext{
Com a vida isolada que vivo, gosto de afastar os olhos de sobre a nossa arena política para ler em minha alma, reduzindo à linguagem harmoniosa e cadente o pensamento que me vem de improviso, e as ideias que em mim desperta a vista de uma paisagem ou do oceano - o aspecto enfim da natureza."
}

reflete tanto o advento da modernidade, quando o indivíduo sente-se em desacordo com o mundo, quanto o princípio da subjetividade romântica, que tenta conjugar em si interior e exterior, tornando o poeta mediador entre natureza e humanidade, divindade $\mathrm{e}$ humanidade. Dito de outra maneira, sentindo-se dissociado da sociedade, o poeta despreza as vicissitudes da política e tenta, por meio da poesia, unir natureza e espírito.

Quer dizer então que os românticos veem, e no sentido mais profundo, o homem como um ser cindido, fragmentado, dissociado. Em função disso,

\footnotetext{
65 “Essa pequena dissonância entre a prática de Gonçalves Dias e a teoria crítica romântica ou, de outro modo, a tendência a tomar de modo legislador um princípio prescrito para ser desenvolvido, não positivamente com um fim em si, mas negativamente como evidência da contradição entre o ideal e a cultura, ilustra o diálogo do autor com os princípios do neoclassicismo." CUNHA, Cilaine Alves. Introdução. In: DIAS, Gonçalves. Cantos. São Paulo: Martins Fontes, 2001, p. XLII- XLIII.

${ }^{66}$ Vale lembrar que a diversidade como unidade da obra aparece na advertência de Harmonies poetiques et religieuses de Lamartine: "Aí estão quatro livros de poesias escritas como foram sentidas, sem ligação, sem sequência, sem transição aparente [...] Essas Harmonias, tomadas separadamente, parecem não ter qualquer relação entre si, consideradas em conjunto, poder-se-ia encontrar nelas um princípio de unidade em sua própria diversidade...' 'Isso porque elas eram destinadas, no pensamento do autor, a reproduzir um grande número das impressões da natureza e da vida sobre a alma humana; impressões variadas em sua essência, uniformes em seu objeto, pois que iriam todas perder-se e descansar na contemplação de Deus'.
} 
sentem-se criaturas infelizes e desajustadas, que não conseguem enquadrar-se no contexto social e que tampouco querem fazê-lo porque a sociedade só iria cindi-las ainda mais. Entre consciente e inconsciente, deveres e inclinações, trabalho e recompensa a brecha só poderia crescer, como parte de um afastamento cada vez maior entre natureza e espírito. Daí o sentimento de inadequação social; daí a aflição e a dor que recebem o nome geral de "mal du siècle"; daí a busca de evasão da realidade e o anseio atroz de unidade e síntese, que tanto marcam a "alma romântica."

Para Cunha, no entanto, na obra do poeta maranhense coadunam-se de forma paradoxal princípios românticos de criação artística, baseados na inspiração e na interioridade do poeta, com a concepção de arte neoclássica no que tange à ideia de que o poeta deveria criar com base na mímesis aristotélica e com o objetivo de transmitir mensagens de cunho moral ${ }^{68}$. Para demonstrar essa proposição, a estudiosa se vale dos poemas "O Prodígio" e "Passamento" da série "Visões"69, "O Orgulhoso" dos Primeiros Cantos, Meditação, e "O homem forte" de Novos Cantos. Ela sublinha, por meio de alguns excertos, como o autor procura disseminar princípios morais de cariz católico e a ideologia política do Segundo Império que é traduzida na questão da necessidade de haver um monarca ilustrado garantindo a unidade e o progresso do Brasil.

Com base nessa rápida análise e comentários dos críticos citados, conclui-se que, de forma similar aos seus pares do primeiro romantismo brasileiro, Gonçalves Dias assume a temática romântica, mas se atém a alguns pressupostos neoclássicos como o a subordinação da poesia a certo pragmatismo político-social.

\begin{abstract}
No conjunto, formam um todo mais homogêneo do que se poderia pensar, marcado por nítida dubiedade nas atitudes e na prática. Ainda um pouco neoclássicos, são por vezes românticos com reservas mentais. Não raro, parecem oscilar entre duas estéticas, como, na atitude política, misturam certo liberalismo de origem regencial ao respeitoso acatamento do Monarca. Devemos, pois, abordá-los com largueza de espírito, prontos a interpretar a sua eventual dubiedade, própria menos dos indivíduos que da época em que viveram - situada entre duas literaturas, dois períodos, duas eras políticas.
\end{abstract}

\footnotetext{
${ }^{67}$ ROSENFELD, Anatol; GUINSBURG, J. Romantismo e Classicismo. In: Op. Cit., p. 272.

${ }^{68}$ CUNHA, Cilaine Alves. Op. Cit., p. XLIX-LVII.

${ }^{69}$ Cunha tem razão em apontar a insistência de certos temas de cariz moral em Dias, no entanto, eles devem ser lidos e analisados singularmente. O tema da ambição em seu indianismo, por exemplo, toma um sentido historicista, em que se assinala a perspectiva aviltante da colonização do Brasil em relação aos povos indígenas. Ademais, ao tratar da cobiça de Portugal, ele retoma uma temática recorrente da Literatura Portuguesa. No caso da série "Visões" é possível pensá-la em outra chave, dialogando com o "Prefácio de Cromwell", no qual a religiosidade cristã explica a necessidade de uma nova expressão estética que dê conta da dicotomia do homem. Tanto em Hugo como em Dias essa transição não é tranquila, mas catastrófica, tumultuada. A propósito, é sintomático que o poema seguinte da obra gonçalvina seja "O Vate", cuja questão do cristianismo relacionado ao romantismo é reiterada.
} 
Época de liquidação do passado e rumos novos para o futuro, na arte e na vida social. ${ }^{70}$

Já no Prólogo a Leonor de Mendonça e em seus folhetins de crítica teatral, conforme observa Giron, Dias perfilhou as mudanças propostas por Victor Hugo de conglobar tragédia e comédia, história e poesia, verso e prosa. Como dramaturgo e folhetinista pleiteou a liberdade de criação para o teatro nacional visando à inovação estética $^{71}$. É interessante notar que em seu próprio prefácio, além de reiterar essas propostas, o autor utiliza um processo de análise similar ao utilizado em suas críticas teatrais enquanto folhetinista. A metodologia de Dias, conforme assaz síntese desenvolvida por Giron, emprega três operações: narrar o desenvolvimento do enredo, observar as características das personagens e julgar as qualidades e defeitos do drama (ação subtraída no Prólogo por se tratar de peça de sua autoria). O escopo principal das críticas e do Prólogo em questão é averiguar se a peça progride assimilando as novidades do drama romântico ou, segundo o dramaturgo, recua esteticamente. G. Dias também considera algumas características essenciais para a efetividade dramática da obra, como a unidade de ação, a fluência do enredo, a naturalidade da história e dos caracteres, e a verdade como elemento propulsor do interesse do público. A ideia de verdadeiro se relaciona com a capacidade de se apropriar do que é profundamente humano proporcionando beleza artística e não com um enredo que imponha uma lição moral no desfecho ${ }^{72}$. Em seus folhetins, o autor se mostra avesso às produções que visavam apenas agradar o público misturando humor e moralidade perpetradas pela cena brasileira e endossadas pelo Conservatório ${ }^{73}$.

Neste trabalho optou-se por analisar os tópicos do preâmbulo de Leonor de Mendonça de acordo com a sequência proposta por Dias, com exceção da epígrafe, para que a comutação entre os comentários deste estudo e o prefácio fosse facilitada aos leitores. Logo no início do texto, Dias afirma que não intenta promover ou obter a

\footnotetext{
${ }^{70}$ CANDIDO, Antônio. Op. Cit., p. 47.

${ }^{71}$ GIRON, Luís Antônio. Op. Cit., p. 185

${ }^{72}$ Idem, ibidem, p. 214.

73 "Faz um autor um drama e manda o seu trabalho para o Conservatório. Sabemos todos o que é o conservatório: aí está para um canto sem que ninguém se lembre dele, e sem que ele se lembre de coisa alguma, extremamente delicado, pudico como uma donzela, com horror às imoralidades do século, recendendo cedro a mirra, será as regras do Scuderi e as ladainhas das Horas Lusitanas, e por fim reprova o Ruy-Blás por ser imoral que uma rainha namore um lacaio, e permite a representação de farsas, obraprima de arte e de estilo, cheia de trocadilhos e de obscenidades de dispersar um regimento de cossacos, mas com uma lição de moral obrigada com que os anjos no céu e na terra, os homens de boa vontade entoam ao Divino hosanas de puro júbilo.” DIAS, Gonçalves. Correio Mercantil. n. 329, 02 de dez. de 1849. In: GIRON, Luís Antônio. Op. Cit., p. 515.
} 
indulgência do leitor através do texto de abertura, mas expor as motivações e perspectivas seguidas no drama, bem como as possibilidades de inovação examinadas e descartadas. Desqualificando os prólogos de função sinestésica ou topológica ${ }^{74}$, mostra-se inimigo das introduções inúteis e promovedoras de obras e autores ${ }^{75}$. $\mathrm{O}$ autor prefere discutir sobre o que fez e o que poderia ter feito, examinando as possibilidades e os percalços numa perspectiva reflexiva. Apesar de G. Dias defender e explorar a função demonstrativa de seu prólogo, no sentido de ser ele uma forma de justificativa para as escolhas feitas na execução da obra, o texto não deixa de ter um cunho persuasivo ao tentar demonstrar a racionalidade do texto e a necessidade da introdução.

\begin{abstract}
É ainda por isto que eu, inimigo de quanto é ou me parece prólogo, nem só os escrevo, como também os leio com prazer, quando eles são feitos, não com o fim inútil de encarecer o merecimento de uma obra que já pertence à crítica e ao público, mas para que o autor nos revele qual foi o seu pensamento, qual a sua intenção, o que pertence exclusivamente ao autor e à arte: ao autor, para que o público se não deixe dominar por juízos ou mal-entendidos ou malintencionados; à arte, para que os principiantes em tal carreira não desacoroçoem com os seus ensaios, sem dúvida imperfeitos, e não deem de mão às belas-letras pela desproporção que de necessidade acharão entre o seu pensamento e a sua expressão. ${ }^{76}$
\end{abstract}

\footnotetext{
74 "Função sinestésica: Há prefácios que ultrapassam a comum função demonstrativa. Procurando "alcançar a docilidade" do leitor, ou "obter a benevolência" (Aristóteles. Arte Retórica. III, § 7) há prefácios que se configuram numa espécie de persuasão. $O$ objetivo é conquistar a atenção do leitor para o ângulo de visão do autor. É uma forma de instituir uma adequação entre emissor e receptor no que diz respeito à mensagem que se estabelece na obra. (...)

Denomina-se de função sinestésica pelo fato de que o autor do prefácio busca estabelecer um campo univisual da percepção da obra, que se identifique com o seu. É sinestésica neste sentido: a percepção do leitor deverá fazer conjunto com a do autor, uma univisão que dará sentido à obra.

O que se observa, a par da função sinestésica, é a existência de certos truques que visam ao convencimento do leitor a fim de que sua benevolência seja obtida. Esse processo de persuasão revela que, nesta função, o autor demonstra uma presença de espírito maior, uma vivacidade e uma racionalização mais acentuadas que, "querendo comprar" a percepção do leitor, mostra uma atenção maior depositada ao prefácio.(...)

Função Topológica: (...) O uso retórico do prefácio na prosa se constitui num hábito tradicional. A sua função como discurso introdutório, tornou-se uma redundância ao todo da narrativa que, por si mesma, já exigia uma introdução, um desenvolvimento e uma conclusão. $O$ prefácio estaria sendo, consequentemente, uma peça ornamental, um discurso não mais introdutório na sua essência, mas um "discurso paralelo" um lugar comum que a tradição viria consagrar. Assim, o prefácio se transformaria num topos da narrativa, isto é, "um clichê de emprego universal na literatura" (Curtius). GIUSTI, César. Teoria e Prática dos Prefácios: um estudo sobre Tutaméia. Disponível em: http://www.cesargiusti.bluehosting.com.br/Litbnk/textos/teorpref.html. Acesso em: 21 mar. 2014.

75 "Um prólogo é como um programa ministerial - enche tempo, embaça e nada afiança. Não há comprometimentos em um prólogo. Não há necessidade de mais outra cousa do que contar-se alguma história, enxertar-se alguma frase da moda - e nem a mínima palavra da obra. Se há aí cousa salvadora, é um discurso do programa para um ministro bisonho, um suspiro para um namorado em apuros, um sorriso anfíbio para um diplomata, uma pitada para um sábio em apertos - ou um prólogo para o escritor." DIAS, Gonçalves (Capitão Jacques). Folhetim, Revista Teatral, Prólogo. O Correio da Tarde, 18 de janeiro de 1848. In: GIRON, Luís Antônio. Op. Cit., p. 422-423.

${ }^{76}$ DIAS, Gonçalves. Prólogo a Leonor de Mendonça. Op. Cit., p. 904.
} 
Pode-se dizer que persevera em G. Dias uma preocupação com a renovação estética, a qual deve se basear na subjetividade e na imaginação, consideradas pressupostos do processo de construção da obra de arte. Segundo Werkema ${ }^{77}$, para o romântico, é do interior do artista que deve decorrer a estrutura da obra, a qual, por analogia com a faculdade imaginativa de seu criador, é orgânica. A imaginação determina os conteúdos e sua expressão, não há, no entanto, exclusão da razão, instrumento indispensável na estruturação das formas.

\begin{abstract}
Ideias e fatos há que diariamente nos passam por diante dos olhos sem que nunca atentemos neles; nós os reputamos coisa corrente e sabida por todos, que por vulgar não nos pode parecer sublime. Mas sobre essa ideia ou fato, que em a nossa memória entesouramos como substância de flores em favo de abelhas, a reflexão trabalha sem descanso, desbasta-o, e tanto se exercita sobre ele, que depois estranhamos de o ver brilhante, belo e muito outro do que a princípio se nos antolhara.

Parece-nos de então que o devemos pesar e meditar com a nossa inteligência, e ver depois as cores que nele mais sobressaem, e as roupagens que melhor se ajeitam às suas formas. A imaginação se incumbe deste trabalho, e desde esse instante está criada a obra artística ou literária [...] ${ }^{78}$
\end{abstract}

Vale lembrar que para os românticos a imaginação é a faculdade que, juntamente com a intuição, permite-nos ver além do que a inteligência ordinária comporta. As criações românticas expressam por meio de formas imaginativas aquilo que vislumbraram para além do comum ao penetrar o mistério das coisas através da intuição ${ }^{79}$. Coleridge ao elogiar a produção de Wordsworth esclarece:

\begin{abstract}
Representaba la unión del sentimento profundo con el profundo pensamiento; el delicado equilibrio entre la verdad de la observación y la facultad imaginativa de transformar los objetos observados, y sobre todo, el don original de agudizar el tono de la atmósfera, y com ello la profundidad y la altura del mundo ideal en que se mueven las formas, los incidentes y las situaciones, y que ha sido despojado por la costumbre, para la visión común, de todo lustre, al apagar sus chispas de luz y secar sus gotas de rocío. ${ }^{80}$
\end{abstract}

Abrams explica que nas teorias expressivas, a poesia é definida como resultado do transbordamento ou expressão do pensamento e dos sentimentos do poeta. As variações dessa concepção inclui a formulação de que a poesia resulta de "um processo imaginativo que modifica e sintetiza as imagens, os pensamentos e os sentimentos do

\footnotetext{
${ }^{77}$ WERKEMA, Andréa Sirihal. Op. Cit., p. 28.

${ }^{78}$ DIAS, Gonçalves. Prólogo a Leonor de Mendonça. Op. Cit., p. 903. Grifos nossos.

${ }^{79}$ BOWRA, C.M. La imaginación romántica. Trad. José Antonio Balbotín. Madrid: Taurus, 1972, p. 1819.

${ }^{80}$ COLERIDGE, Samuel Taylor. Biographia Literaria, I, Oxford, 1907, p. 59 apud BOWRA, C.M. Op. Cit., p. 19.
} 
poeta." Os elementos do mundo exterior são convertidos em poesia quando operados pelos sentimentos e pela mente do poeta. ${ }^{81}$

Embora em sua obra de estreia Dias tenha se eximido de definir a poesia por acreditar que o sentimento não poderia ser abarcado e traduzido em palavras, para Peixoto, nos Primeiros Cantos subsistiria a crença no poder da palavra poética, enquanto em Leonor de Mendonça a consciência da incapacidade expressiva da palavra se sobrepõe. ${ }^{82}$

\begin{abstract}
Em Gonçalves Dias, efetivamente, os prólogos aos Primeiros Cantos e a Leonor de Mendonça - ambos de 1846 - coexistem, opondo-se: no primeiro, a confiança em uma linguagem capaz de representar o mundo mágico que são, para o poeta, a alma e a natureza, no segundo, a consciência de que essa linguagem é falha e de que, consequentemente, a obra estará sempre aquém das emoções vividas ou sonhadas. Por isso é que o poeta nos fala das 'dores superiores a toda expressão', dos 'sentimentos que se não exprimem e 'das cores que se não desenham', em suma, da incapacidade de se representar, pela linguagem, toda a magia da imaginação, toda a profundidade da alma e todas as angústias do coração. ${ }^{83}$
\end{abstract}

Com efeito, no prefácio do drama há uma preocupação em descrever a construção do objeto de arte: o autor se valeria do referencial ("ideias e fatos") apenas como matéria a ser trabalhada, pois o vulgar, segundo ele, só é transformado em sublime se meditado com a inteligência e disposto numa forma harmônica através da imaginação ${ }^{84}$. Ou seja, no caso do texto em questão, podemos inferir que o dado histórico foi desbastado, meditado e sujeitado a uma forma adequada à proposta do autor sem, contudo, compreender toda a ideia que a reflexão aventa ${ }^{85}$. O processo artístico toma da natureza ou da história elementos que possam ser dinamizados pela

${ }^{81}$ ABRAMS, M. H. O Espelho e a Lâmpada: teoria romântica e tradição crítica. Trad. Alzira Vieira Allegro. São Paulo: Editora Unesp, 2010, p. 41-42.

82 PEIXOTO, Sergio Alves. A consciência criadora na poesia brasileira: do barroco ao simbolismo. São Paulo, 1999, p. 108.

${ }^{83}$ Idem, ibidem.

${ }^{84}$ Peres chama atenção para o impressionante domínio da linguagem, a capacidade de síntese e a imaginação poderosa em Gonçalves Dias quando examina uma carta do autor enviada ao amigo Antônio Henriques Leal em dezembro de 1861. Em expedição científica ao Amazonas por conta de seus trabalhos no Instituto Histórico e Geográfico Brasileiro, Dias escreve essa carta que nos deixa entrever o pesquisador, mas sobretudo o poeta e o seu processo de criação poética. A carta passa da simples descrição do fenômeno para uma dicção poética que expressa a experiência do sublime e termina com o registro de cunho científico. Para mais detalhes consultar: PERES, Marcos Flamínio. A fonte envenenada: transcendência e história em Gonçalves Dias. São Paulo: Nova Alexandria, 2003, p. 38-41.

85 “.... a arte é o produto combinado do objetivo e do projetado. A arte é 'a conciliadora e mediadora entre a natureza e o homem. Ela tem, portanto, o poder de humanizar a natureza, de infundir os pensamentos e as paixões do homem em tudo aquilo que é objeto de sua contemplação. ' 'A poesia também é puramente humana, pois todos os seus materiais provêm da mente e todos os seus produtos são para a mente. ' No entanto, 'ela faz uso das naturezas para evocar, expressar, modificar os pensamentos e sentimentos da mente.’ ABRAMS, M.H. Op. Cit., p. 79 citando Coleridge. 
imaginação e não aqueles que por sua beleza e perfeição devam servir de modelo. No entanto, após descrever esse processo, Dias o põe em questão, uma vez que nem tudo o que a imaginação propõe é possível concretizar: "há entre elas [obra delineada e obra já feita] a distância que vai do ar a um sólido, do espírito à matéria. A imaginação tem cores que se não desenham; a alma tem sentimentos que não se exprimem; o coração tem dores superiores a toda expressão." 86 Com a materialização do sentimento, perdas irreparáveis ocorrem ${ }^{87}$, fato que dever ser considerado quando uma obra é criticada. Assim, a noção de arte como reflexão, ideia crucial nas obras de Schiller, pode ser entrevista na perspectiva apresentada no Prólogo de Leonor de Mendonça.

No ensaio Poesia ingênua e sentimental, o dramaturgo alemão já havia alertado sobre a impossibilidade de representação da natureza pela arte moderna. Ao contemplar o sensível, o poeta sentimental reflete por meio de suas faculdades de pensamento, a representação da natureza, portanto, é uma expressão de sua reflexão e não de suas sensações. O poeta moderno pode escrever poesia ingênua, mas como reflexão e, portanto, sentimental, expressando a nostalgia da aspiração de uma ideia irrealizável. “Um Ideal é a Ideia em imagem, ou seja, numa representação imaginada in concreto. $\mathrm{O}$ Ideal jamais exprime toda Ideia por causa de impedimentos in concreto e, no entanto, a Ideia é aquilo pelo qual o Ideal deve ser julgado". ${ }^{88}$ Para Schiller, o que distingue o homem da natureza é a liberdade que, paradoxalmente, apartar-nos da natureza e da perfeição:

\begin{abstract}
Enquanto meros filhos da natureza, fomos felizes e perfeitos; tornamo-nos livres, e perdemos as duas coisas. Surge daí uma dupla nostalgia, e bastante desigual, em relação à natureza: uma nostalgia de sua felicidade e uma nostalgia de sua perfeição. ${ }^{89}$
\end{abstract}

Em vez de querer voltar à natureza, o artista deve unir o infinito da natureza com o seu próprio privilégio infinito para gerar o Ideal, ou seja, por meio de sua liberdade ${ }^{90}$. O objeto estético alude a uma Ideia e é nela que consiste a sua força poética. O poeta

\footnotetext{
${ }^{86}$ DIAS, Gonçalves. Prólogo a Leonor de Mendonça. In: Op. Cit., p.911.

87 "Se soubesses como as maiores ideias se apequenam ao encerrar-se no círculo de ferro da palavra, se soubesse que diáfanos, lépidos, impalpáveis são os véus de ouro que flutuam na imaginação ao envolver essas misteriosas figuras criadas por ela mesma e das quais apenas conseguimos reproduzir o descarnado esqueleto; se soubesses quão imperceptível é o fio de luz que ata entre si os pensamentos mais absurdos que nadam em seu caos; se soubesses...” BÉCQUER, Gustavo Adolfo. Cartas literárias a uma mulher. In: PALMA, Anna; CHIARINI, Ana Maria; TEIXEIRA, Maria Juliana Gambogi. O Romantismo Europeu: antologia bilíngue. Belo Horizonte: Autêntica Editora, 2013, p. 205.

${ }^{88}$ SCHILLER, Friedrich. Poesia ingênua e sentimental. São Paulo: Iluminuras, 1992, p. 113, nota n. 8.

${ }^{89}$ Idem, Ibidem, p. 18.

${ }^{90}$ Idem, Ibidem, p. 53.
} 
sentimental sempre tem de lidar com suas representações e sensações opostas, com a realidade que é finita e com a Ideia infinita ${ }^{91}$. O poeta sentimental tenta restabelecer a unidade perdida com a natureza por meio da abstração.

No texto gonçalvino, há também a implicação da noção de genialidade, pois ao comentar o processo do fazer artístico, ele complementa que depois de a matéria ser refletida e imaginada, cria-se a obra de arte, seja ela perfeita ou imperfeita. O gênio cria a partir de um estado de exaltação em que se expressa com toda a sinceridade e nisso reside o valor da obra ${ }^{92}$, mesmo sendo ela monstruosa segundo os preceitos clássicos, que recusa, por exemplo, a mistura de gêneros e de tom. ${ }^{93}$

Em seus ensaios sobre o sublime ${ }^{94}$, com base em pressupostos kantianos (sublime matemático e sublime dinâmico), Schiller desenvolve a noção de sublime teórico e sublime prático a partir da ideia de que como seres sensíveis, teríamos dois impulsos fundamentais: o impulso de representação (conhecimento) e o impulso de autoconservação (sentimentos). Esses dois impulsos nos mantêm dependentes da natureza quando ela não proporciona os meios para a obtenção do conhecimento e quando não proporciona condições para a nossa existência. No entanto, por meio da razão podemos, contrariamente, tornarmo-nos independentes da natureza de duas formas, quando pensamos mais do que conhecemos empiricamente e quando passamos por cima das condições naturais através da vontade.

O sublime prático se diferencia, assim, do sublime teórico pelo fato de que o primeiro está em conflito com as condições de nossa existência, ao passo que o último apenas com as condições do conhecimento. Um objeto é sublime de modo teórico na medida que traz consigo a representação da infinitude, para cuja apresentação a faculdade da imaginação não se sente à altura. Um objeto é sublime de modo prático na medida em que traz consigo a representação de um perigo que nossa força física não se sente capaz de vencer. Sucumbimos

\footnotetext{
${ }^{91}$ Idem, Ibidem, p. 64.

92 "Obedecendo à inspiração subjetiva e ao impulso expressivo, produz obras originais, talvez imperfeitas no que se refere à forma exterior, mas dotadas de unidade íntima, de 'forma interna' e de força característica, como tais bem mais importantes do que o ideal da beleza (em que há sempre uma parcela de 'mentira', por lhe faltar plena espontaneidade)." ROSENFELD, Anatol. Op. Cit., 1991, p. 13-14.

93 “A mistura dos gêneros [...] é combatida por Horácio mediante a célebre analogia de um livro com a figura desproporcionada de uma mulher com mistura de peixe, ave e cavalo, em que também se afirma que não se deve misturar ave com serpente, cordeiro com leão. Trata-se do início da Arte Poética [...] Nela, Horácio aborda sobretudo a invenção ou escolha adequada do assunto, prescrevendo a pureza dos gêneros e o princípio de que cada gênero possui uma matéria e uma elocução adequadas." Essa doutrina se perpetua no neoclassicismo, por exemplo, nos tratados poéticos e na literatura setecentista portuguesa. TEIXEIRA, Ivan. Mecenato Pombalino e Poesia Neoclássica: Básilio da Gama e a poética do encômio. São Paulo: Edusp, 1999, p. 156-157.

${ }^{94}$ Do Sublime (Para uma exposição ulterior de algumas ideias kantianas) artigo publicado na revista Neue Thalia em 1792-1793 e Sobre o Sublime publicado em 1801 na Die Horen.
} 
na tentativa de realizar uma representação do primeiro; e sucumbimos na tentativa de nos contrapor ao poder do segundo. ${ }^{95}$

É possível pensarmos que no Prólogo, Gonçalves Dias, ao descrever o processo artístico, vale-se da concepção schilleriana do sublime teórico abarcando a oposição entre as limitações no plano sensível e a liberdade no plano racional, por isso o que a natureza apresenta não é suficiente para o desenvolvimento do objeto de arte.

É necessário que a liberdade de pensamento transforme o vulgar em sublime. Essa colocação explicaria outra noção artística compartilhada pelos dois artistas, a de que seria preciso trabalhar a matéria histórica de forma a conferir-lhe uma verdade poética, por isso, às vezes, é preciso modificá-la. Para Schiller, somente alguns homens como Catão, Aristides, Fócion e figuras afins conseguiram elevar-se por feitos realizados pela razão autônoma em detrimento de ações subjugadas à natureza ${ }^{96}$, e, dessa forma, atingiram o sublime ${ }^{97}$. Além disso, tais exemplos históricos são fundamentais para demonstrar "a perversa fatalidade" e nos ensinar a nos apegar ao que há de constante em nós, àquilo que não está submetido à natureza, a nossa liberdade moral. As cenas patéticas da humanidade em luta com a fatalidade na história, imitadas pela arte trágica ampliam a capacidade de sentir do coração humano para além do sensível. A abundância de exemplos históricos em que o homem se põe em luta com as pressões do mundo sensível superando-o moralmente explica a importância da história na dramaturgia de Schiller. Benjamin assevera que o dramaturgo alemão buscava, no contexto da história, "configurar de forma reflexiva a noção de destino enquanto

95 SCHILLER, Friedrich. Do sublime (Para uma exposição ulterior de algumas ideias kantianas). In: SÜSSEKIND, Pedro (Org). Friedrich Schiller: Do sublime ao trágico. Trad. e ensaios Pedro Süssekind e Vladimir Vieira, Belo Horizonte: Autêntica, 2011, p.25.

${ }^{96}$ SCHILLER, Friedrich. Sobre o sublime. In: SÜSSEKIND, Pedro (Org). Op. Cit., p. 69. Transcrevo a nota de rodapé n. 44 da referida obra que esclarece melhor o sentido de sublime inerente às ações dessas figuras históricas, a saber, a superioridade moral frente à tirania da natureza, ou seja, mesmo oprimidos pelas forças naturais, entre as quais Schiller considera os afetos humanos, esses vultos históricos mantêmse racionalmente livres: "O senador romano Marcus Porcius Cato Uticensis, ou Catão, o Jovem (95-46 a.C.), seguidor da filosofia estoica, era conhecido por sua tenacidade e sua integridade na prática política. O estadista ateniense Aristides (ap. 550-467 A. C.), chamado de O Justo, foi mandado para o exílio sem ser culpado. Fócion (402-318 a.C.), o ateniense, considerado um modelo de todas as virtudes, foi eleito general 45 vezes. As histórias dos três são contadas por Plutarco em suas Vidas Paralelas.

${ }_{97}$ Vale lembrar que Burke já associara o sublime com a piedade valendo-se do exemplo da história de Catão. O terror do destino alheio nos causa deleite porque não nos violenta diretamente e sentimos piedade inspirados pelo amor e a simpatia social que compartilhamos. "Tanto Cipião quanto Catão são caracteres virtuosos, mas causam-nos uma emoção mais profunda a morte violenta do segundo e a ruína da nobre causa a que ele aderira do que os merecidos triunfos e ininterrupta prosperidade do primeiro, pois o terror é uma paixão que sempre gera deleite quando sua ação não é muito direta, e a piedade é acompanhada de prazer, porque nasce do amor e da afeição social." BURKE, Edmund. Uma investigação filosófica sobre a origem de nossas ideias do sublime e do belo. Trad., apres. e notas Enid Abreu Dobránszky, Campinas, SP: Papirus: Editora da Universidade de Campinas, 1993, p. 54. 
antítese da liberdade individual"98, noção que se aproxima da expressão gonçalvina, "fatalidade cá da terra". Similarmente, para Schelling, a história seria o lugar do debate entre a liberdade e a necessidade, entre a consciência e a inconsciência ${ }^{99}$, em que o homem exercita a liberdade visando o Absoluto.

Feita a comparação com o pensamento schilleriano, voltemos mais estritamente ao Prólogo do drama em questão, nele Dias prefere falar sobre o que prometera fazer, não o que fez, pois, dessa forma, ele explicita as limitações do processo artístico descrito anteriormente. Além disso, ele apresenta outras possibilidades de desenvolvimento para o drama, principalmente formais, como o uso simultâneo do verso e da prosa e a utilização da música em cena, que foram ponderadas, mas rejeitadas, devido sobretudo a inconveniência de tais inovações para o tacanho cenário teatral brasileiro.

\begin{abstract}
Agora, sim, tomamos contacto com algo que o Romantismo no Brasil não ousara, até então, tocar: a obra de arte é imperfeita e o artista um fracassado. Esse a priori que o Romantismo alemão já vivenciara tão agonicamente, começa com Gonçalves Dias a delinear-se de modo mais claro em nossa poesia. A perfeição que o artista tinha como objetivo principal passa a ser vista como um malogro impossível de se evitar porque a linguagem, de que necessariamente o poeta se utiliza, traz em si a marca do artificial, o peso do raciocínio lógico e do uso comum. ${ }^{100}$
\end{abstract}

Para explicar o que intentou fazer, o poeta expõe quais foram a ideia, a ação e os caracteres que serviram para edificar o drama, além de argumentar sobre a elocução e a encenação. É curioso que, ao seguir essas prerrogativas, embora trate de um drama, Dias dialoga com a Poética aristotélica, a qual expõe as partes que compõem a tragédia. Aristóteles afirma que a tragédia é constituída de seis partes: a fábula (ação), os caracteres, a elocução, o pensamento, o espetáculo apresentado, o canto (melopeia). Com as devidas adaptações ao teatro de seu tempo, Dias contempla em seu prólogo as seis partes da tragédia.

\footnotetext{
A imitação de uma ação é o mito (fábula); chamo fábula a combinação dos atos; chamo caráter (ou costumes) o que nos permite qualificar as personagens que agem; enfim, o pensamento é tudo que nas palavras pronunciadas expõe o que quer que seja ou exprime uma sentença. Daí resulta necessariamente que a tragédia se compõe de seis partes, segundo as
}

98 BENJAMIN, Walter. Origem do drama trágico alemão. Ed. e trad. João Barrento. Belo Horizonte: Autêntica, 2011, p. 125.

${ }^{99}$ BORNHEIM, Gerd. Filosofia do Romantismo. In: GUINSBURG, J. Op. Cit., p. 106.

${ }^{100}$ PEIXOTO, Op. Cit., p. 107. 
quais podemos qualificá-la: a fábula, os caracteres, a elocução, o pensamento, o espetáculo apresentado, o canto (melopeia). ${ }^{101}$

A ação é a morte de Leonor de Mendonça pelo marido que a julgou adúltera. Gonçalves Dias optou por fazer da duquesa inocente, mesmo sabendo que o remorso da protagonista seria mais instrutivo que o desespero, e o crime, mais dramático que a virtude $^{102}$. Ou seja, se Leonor de Mendonça fosse culpada e a sua morte um castigo, a peça se aproximaria dos moldes didáticos e moralistas do melodrama e atrairia mais a atenção do público. O poeta brasileiro explica que preferiu seguir o pior para que a obra incluísse a severidade do pensamento: “(...) como diz Victor Hugo - em cada mulher formosa há sempre um esqueleto." ${ }^{103} \mathrm{O}$ trecho citado por Dias encontra-se no prefácio hugoano de Angelo, drama de 1835:

\begin{abstract}
Não é necessário dizer que as condições de arte devem ser em primeiro lugar preenchidas. A curiosidade, o interesse, o divertimento, o riso, as lágrimas, a observação perpétua de tudo o que é natureza, o invólucro maravilhoso do estilo, o drama deve ter tudo isso, sem o que não seria drama: porém, para ser completo, é preciso que tenha também a vontade de ensinar, ao mesmo tempo que vontade de agradar. Deixai-vos encantar pelo drama, porém que a lição esteja dentro e que se possa sempre a encontrar quando se quiser dissecar essa bela coisa viva, tão fascinante e poética, tão magnificamente vestida de ouro, de seda e de veludo. No mais belo drama deve sempre haver uma ideia severa, como na mais bela mulher há sempre um esqueleto. ${ }^{104}$
\end{abstract}

No entanto, o texto de Hugo que serviu como estímulo parece não esclarecer totalmente a escolha estética operada por G. Dias, o qual abre mão da fórmula "didatizante" do melodrama, ou seja, é preciso atentar como se dá a ideia de ensinamento em Leonor de Mendonça que, apesar de ter se inspirado no Prefácio a Angelo, não expressa a mesma objetividade. Se o relacionarmos com a distinção schilleriana do belo e do sublime, pode-se inferir que o autor brasileiro concebe que um drama completo deve ser belo e sublime para que possa, além de deleitar, educar esteticamente o público, pois, nas palavras de do dramaturgo alemão: “apenas por meio da beleza nunca experimentaríamos que estamos destinados a nos mostrar como puras inteligências, e que somos capazes disso.”105

101 ARISTÓTELES. Poética. Trad. e notas de Eudoro de Sousa. Lisboa: Guimarães Editores, 1964, p. 271.

102 DIAS, Gonçalves. Prólogo a Leonor de Mendonça. Op. Cit., p. 904.

${ }^{103}$ Idem, ibidem.

${ }^{104}$ HUGO, Victor. Prefácio a Angelo. In: HUGO, Victor. Obras completas. Trad. Hilário Correia. São Paulo: Editora das Américas, 1960, vol. XXXIX.

${ }^{105}$ SCHILLER, Friedrich. Sobre o sublime. In: SÜSSEKIND, Pedro (Org). Op. Cit., p. 61. 
Para Schiller, o belo traduz a liberdade que gozamos enquanto homens da natureza, pois a beleza faz com que nossos impulsos sensíveis se harmonizem com a razão. Já a liberdade advinda do sublime nos eleva além da natureza, porque o espírito age como se não fosse coagido pelos impulsos sensíveis, mas agisse segundo suas próprias leis. No entanto, o sentimento do sublime compreende prazer e dor. É nesse sentido que o drama deve abarcar a severidade, e não só a beleza, a fim de alcançar a sublimidade ${ }^{106}$. Vale lembrar que Schiller também assevera que através da tragédia o homem aprende a transformar o sofrimento sensível em sentimento sublime. A exposição repetitiva a infortúnios artificiais prepara o homem para ganhar autonomia diante de um sofrimento real ${ }^{107}$. A artificialidade do infortúnio faz com que o homem consiga libertar-se da causalidade sensível por meio da razão sem correr nenhum risco $^{108}$.

A aproximação com as propostas schillerianas é mais evidente pelo aproveitamento do acontecimento histórico devido ao fato de eles muitas vezes trazerem exemplos de superação espiritual diante das opressões do mundo sensível, que, transformados em arte trágica, passam a ser uma forma de despertar o espírito do homem para a liberdade. Se Gonçalves Dias tivesse optado por fazer de Leonor de Mendonça culpada, o espectador não poderia sentir o sublime que, de acordo com o pensamento schilleriano, advém da faculdade autônoma do pensamento e da vontade, e, portanto, desenvolve a capacidade de sentir para além do mundo sensível. A inocência e superioridade moral da protagonista diante do poder opressivo do duque e da iminência da morte seria um exemplo do exercício de libertação da tirania do mundo sensível. Leonor de Mendonça, nesse sentido, estaria muito distante dos melodramas cuja moral maniqueísta e simplória tem um caráter politicamente pragmático.

As cenas patéticas da humanidade em luta com o destino, da luta irrefreável da felicidade, da segurança enganada, da injustiça triunfante e da inocência

\footnotetext{
106 "Como é nossa destinação, mesmo com todas as limitações sensíveis, que nos orientemos pelo guia dos espíritos puros, o sublime tem de ser acrescentado ao belo para fazer da educação estética um todo perfeito, ampliando a capacidade de sentir do coração humano segundo a amplitude completa de nossa destinação, e para além do mundo sensível." Idem, ibidem, p. 73.

107 "Quanto maior a frequência com que o espírito renova esse ato de autonomia, maior a sua preparação para fazê-lo e mais ganha vantagem sobre o impulso sensível, de modo que ele, afinal, caso o infortúnio artificial e imaginado dê lugar a um infortúnio sério, estará em condições de lidar com ele como se fosse artificial e - supremo arroubo da natureza humana! - dissolver o sofrimento real em uma emoção sublime. O patético pode dizer-se então, é uma inoculação do destino inevitável, pela qual sua malignidade é retirada, e seu ataque é dirigido ao lado forte do ser humano. Idem, ibidem, p. 71. 108 SÜSSEKIND, Pedro. Schiller e a atualidade do sublime. In: SÜSSEKIND, Pedro (Org). Op. Cit., p. 100.
} 
que sucumbe, cenas que a História expõe em abundância e que a arte trágica, imitando, põe diante dos nossos olhos. Pois onde se encontraria alguém que, tendo uma aptidão moral não de todo desleixada, pode ler sobre a luta obstinada e no entanto vã de Mitrídates, sobre a derrocada das cidades de Siracusa e Cartago, e demorar-se nessas sem venerar com um arrepio a grave lei da necessidade, sem puxar as rédeas de seus apetites por um instante, e sem, tomado por essa eterna infidelidade do mundo sensível, aferrar-se ao que há de permanente em seu peito? ${ }^{109}$

No entanto, é preciso refletir sobre a inocência de Leonor, a qual se circunscreve apenas ao âmbito histórico-social, pois como ela mesma confessa: "Serei criminosa para Deus, porém sou inocente para os homens." Essa dicotomia põe em questão a superioridade moral da protagonista no sentido schilleriano, porque a duquesa não admite que a sua falta deva ser punida, o que a distancia de um idealismo. Pode-se conjecturar, portanto, que a "verdade incisiva e áspera" em Dias não se vincula estritamente ao "pedagogismo hugoano" nem à sublimidade schilleriana. Para compreender em que incide a severidade comentada pelo autor brasileiro é preciso se ater ao conceito de fatalidade exposto no Prólogo, o qual se diferenciaria tanto da tragédia clássica quanto dos Schicksaldramas, pois não se funda na implacabilidade do destino, mas nas circunstâncias histórico-sociais.

De qualquer forma, a essência do trágico ${ }^{110}$, o combate inócuo, mas persistente do herói trágico, que mesmo diante do inevitável mantém sua dignidade, reverbera-se no drama gonçalvino. A diferença crucial $^{111}$, que reflete a inclusão de uma perspectiva historicista, fica por conta da ênfase dada ao contexto histórico-social como propulsor do destino da duquesa ${ }^{112}$. O fatum para os gregos antigos não se relaciona com o problema da incompatibilidade entre o homem e o mundo, mas pela noção de partilha

${ }^{109}$ SCHILLER, Friedrich. Do Sublime. In: SÜSSEKIND, Pedro (Org). Op. Cit., p. 72.

${ }^{110}$ Vale lembrar que Schiller se opunha à importância dada ao destino na tragédia grega. Para ele, a total sujeição do homem à fatalidade é humilhante à liberdade e incompreensível para a razão. $\mathrm{O}$ conflito do homem na tragédia deve servir justamente para mostrar a liberdade moral alcançada pelo homem quando abdica do estado de conservação. MACHADO, Roberto. O nascimento do trágico: de Schiller a Nietzsche. Rio de Janeiro: Jorge Zahar, 2006, p. 73.

${ }^{111}$ Em seu estudo sobre a origem do drama trágico alemão, Benjamin chama atenção para essa questão assinalando que o drama se distingue da tragédia pelo conteúdo. O objeto do drama é a vida histórica e o da tragédia, o mito. BENJAMIN, Walter. Op. Cit., p. 56.

112 "O destino, como força imprevisível que os homens devem simplesmente aceitar, produziu na arte dramática aquela tragédia fatídica que, na literatura alemã, desde o 24 de Fevereiro de Werner, goza, e com razão, de péssimo conceito. Mas a verdadeira tragédia se origina da tensão entre as incontroláveis forças obscuras, a que o homem está abandonado, e a vontade deste para se lhes opor, lutando. Essa luta é em geral sem esperança, afundando mesmo, o herói cada vez mais nas malhas do sofrimento, e muitas vezes até ao naufrágio total. Todavia, combater o destino até o fim é o imperativo da existência humana que não se rende. $\mathrm{O}$ mundo dos que se resignam, dos que se esquivam à escolha decidida, constitui $\mathrm{o}$ fundo diante do qual se ergue o herói trágico, que opõe sua vontade inquebrantável à prepotência do todo e, inclusive na morte, conserva íntegra a dignidade da grandeza humana." LESKY, Albin. A tragédia grega. 2. ed., São Paulo: Perspectiva, 1976, p. 140. 
(moîra). A fatalidade é inerente ao homem e não imposta a ele, por isso não pode ser pensada como uma transcendência, mas como imanência.

\begin{abstract}
A Fatalidade se deu à visão grega como uma partilha ou lote; sua coerção sobre os entes se deu como a impossibilidade de cada ente (divino ou humano) ultrapassar a esfera que lhe era própria sem que com isso transgredisse a esfera que constituía os privilégios (timé) de outro Deus. A força dessa Fatalidade é a da facticidade da partilha. ${ }^{113}$
\end{abstract}

A fatalidade exposta no Prólogo dialoga com preceitos característicos do movimento pré-romântico alemão, os quais, por sua vez, relacionam-se com ideias rousseaunianas de valorização da sensibilidade. A fatalidade torna-se intrínseca à história de indivíduos singulares, pois a única saída para esses heróis trágicos em conflito com a sociedade e privados de liberdade é a morte. Na dramaturgia stürmer, o herói mantém vínculos com a natureza e privilegia seus sentimentos e, por isso, não consegue adequar-se à sociedade civilizada que é, mormente, o regime político absolutista. Estabelece-se uma relação de causa e consequência, ou seja, os hábitos artificiais da civilização tolhem os sentimentos e a liberdade dos indivíduos mais sensíveis incidindo em fatalidade.

A noção de trágico moderna se configura a partir da leitura kantiana do sublime em Longino. Em a Crítica da Razão Pura, Kant desenvolve uma formulação filosófica do sublime definindo-o como a superioridade espiritual do homem em relação às forças naturais. Schiller, por sua vez, aplica essa proposição do sublime na teoria da tragédia, considerando-a o gênero mais propício para expressar a incompatibilidade entre o homem e o mundo. Diferentemente do pensamento grego, a fatalidade não está na imanência do ser e seu quinhão, mas no embate, no homem, entre o espiritual e o sensível. ${ }^{114}$ A função da tragédia para o dramaturgo alemão é representar o suprassensível, a liberdade do mundo moral. A solução proposta por Schiller é mostrar a vontade humana em luta contra a tirania da natureza na qual se incluem os impulsos e

113 TORRANO, Jaa. O mundo como função das musas. In: HESÍODO. Teogonia: a origem dos deuses. 7. ed. São Paulo: Iluminuras, 2007, p. 50.

${ }^{114}$ Para Herder o entendimento humano não interfere com a mesma força na condução das mudanças no mundo como o destino: 'a propósito da desmesurada fama que alcançou o entendimento humano, que ao longo dos tempos foi sempre menos ele do que - se assim me posso exprimir - um destino cego, quem se encarregou de lançar e de conduzir as coisas que foram acontecendo, quem exerceu de fato a ação de transformação geral do mundo.' HERDER, Johann Gottfried. Também uma filosofia da história para a formação da humanidade. Lisboa: Edições Antígona, 1995, p. 64-65 apud MARQUES, Wilton José. Gonçalves Dias: o poeta na contramão (literatura e escravidão no romantismo brasileiro). São Carlos: EdUFSCar, 2010, p. 196. 
as paixões que regem a história e as intrigas políticas ${ }^{115}$. Ao destacar as circunstâncias “cá da terra”, Gonçalves Dias apresenta um dos polos de oposição do embate trágico moderno, os aspectos sensíveis que fazem a protagonista e Alcoforado sucumbirem. A fatalidade proposta em Leonor de Mendonça se avizinha da noção desenvolvida por Schiller, mas não congloba a questão da superioridade moral da protagonista, a qual não abre mão da vida como fazem os caracteres schillerianos.

Foi Friedrich Schiller quem reconheceu nestas formulações ideias que poderiam ser aplicar proveitosamente à teoria da tragédia. [...] mas a terceira Crítica de Kant teve um profundo impacto nele e o levou a escrever uma série de notáveis ensaios entre o verão de 1790 e o inverno de 1792, nos quais concebeu o trágico de acordo com o modelo do sublime e interpretou o gênero da tragédia como o veículo para lhe dar expressão. Assim, Schiller formulou pela primeira vez uma visão do trágico como um aspecto fundamental da existência humana, indicativo da irremediável, dolorosa incompatibilidade entre o homem e o mundo em que ele se acha por acaso uma ideia absolutamente ligada à secularização e ao desencantamento do mundo e é, claro, largamente estranho à maior parte do pensamento grego antigo [...]. ${ }^{116}$

Ainda assim é preciso refletir em que medida a fatalidade em L.M. ${ }^{117}$ se relaciona à teoria do drama de Hugo e/ou do sublime schilleriano ${ }^{118}$. No caso da obra em questão como um todo, e não apenas o exposto em sua introdução, a intriga que envolve as personagens, bem como sua própria configuração, baseia-se na disparidade, nos contrastes e nas oposições consoante a proposta de junção do sublime e do grotesco hugoano. A escolha pela "fatalidade social" congregando os contrários reverbera a forma estética que, segundo Hugo, reflete as oposições que existem também na vida. A estrutura do drama do autor francês é adotada por Gonçalves Dias, contudo, sem tornarse uma cartilha. As outras leituras do autor brasileiro também acabam se refletindo nessa obra ímpar que é Leonor de Mendonça. Dessa forma, a ideia de que nos eventos históricos podem ser encontrados exemplos de superação do sensível perpassa a obra

\footnotetext{
115 “A tragédia apresenta a vontade humana no seu desafio às forças do universo e da história, mostra o homem sofrendo, mas resistindo ao sofrimento graças a sua dignidade sublime e indestrutível. Assim leva o espectador a entrever a possibilidade, por remota que seja, de um último sentido, de uma ordem universal transcendente e de uma harmonia absoluta em que é superado o abismo entre o mundo das necessidades natural e da liberdade moral, entre o dever e as inclinações dos impulsos." ROSENFELD, Anatol. Introdução. In: SCHILLER, Friedrich. Op. Cit., p. 11.

116 MOST, Glenn W. Da tragédia ao trágico. In: ROSENFELD, Kathrin Holzermayr (org.). Filosofia \& Literatura: o trágico. Rio de Janeiro: Jorge Zahar, 2001, p. 34-35.

${ }_{117}$ Abreviatura do título da obra estudada Leonor de Mendonça.

118 A dúvida sobre com qual dos autores Gonçalves Dias dialoga de forma mais direta quando discute suas escolhas estéticas e o conceito de fatalidade no Prólogo foi acentuada pela reflexão que Vagner Camilo faz sobre a binomia na obra Lira dos Vinte Anos de Álvares de Azevedo. CAMILO, Vagner. Risos entre Pares: poesia e humor românticos. São Paulo: Editora da Universidade de São Paulo; Fundação de Amparo à Pesquisa do Estado de São Paulo, 1997, p. 73-74.
} 
gonçalvina. É preciso ressaltar que as teorias de Schiller se distanciam das de Hugo, pois o dramaturgo alemão não determina que haja a fusão dos contrários, mas apenas o contraponto entre o real e o Ideal ${ }^{119}$. Assim, diferentes acepções são perfilhadas por G. Dias. Aqui há um exemplo da diferença entre intenção e resultado, pois o poeta brasileiro pretendia seguir os passos de Hugo no que concerne ao drama deixando tal propósito bem claro no Prólogo. No entanto, o estilo adotado, a concisão e os meios tons atenuam o impacto da ênfase que ele tencionava dar à "fatalidade cá da terra", o que acaba por evidenciar o cunho poético (espiritual) em detrimento do de crítica social, o qual, em Hugo, é mais incisivo. A diferença entre o estilo gonçalvino e hugoano permite a aproximação com a obra de Schiller, comparação aventada por críticos como Jacobbi e Volobuef. Por outro lado, uma leitura mais atenta da obra, principalmente das falas de Leonor e de Alcoforado, desvela por que a fatalidade que nasce dos hábitos sociais incide justamente sobre essas duas personagens, as quais representam, no âmbito da peça, os indivíduos mais fracos daquela sociedade, ou seja, esses caracteres encenam o tema da injustiça social tão explorado nos dramas franceses depois de $1830^{120}$. Vale observar também que Hugo, em outro trecho do Prefácio a Angelo, complementa a ideia contida no trecho "No mais belo drama deve sempre haver uma ideia severa, como na mais bela mulher há sempre um esqueleto" esclarecendo que não se trata da mera inclusão de uma lição moral no drama. A obra deve incluir o humano, o social e o histórico fazendo com que as personagens reflitam a essência da civilização de seu tempo em uma configuração tão animada como a vida de forma que a lição ou o pensamento que preside a peça não seja explicitado, mas torne-se inerente à obra.

Misturar nesta obra, para satisfazer a necesidade de espírito que sempre
sentiu o passado no presente e o presente no passado, ao elemento eterno o
elemento humano, ao elemento social o elemento histórico. Pintar, de
passagem, por ensejo desta ideia não somente o homem e a mulher, não
somente essas duas mulheres, não somente esses três homens, mas todo um
século, todo um clima, toda uma civilização, todo um povo. Erguer sobre
esse pensamento, segundo os dados especiais da história, uma aventura de tal
maneira simples e verdadeira, tão viva, tão palpitante, tão bem real, que aos
olhos da multidão pudesse ocultar a própria ideia assim como a carne oculta
os ossos. ${ }^{121}$

${ }^{119}$ Idem, ibidem, p. 74.

${ }^{120}$ Arêas sugere que: “À ligação da obra com Schiller, proposta por Ruggero Jacobi, certamente por conta da tradução feita pelo poeta, Décio de Almeida Prado com acerto prefere outros modelo: o Antony, de Alexandre Dumas, ou o Chatterton, de Vigny, ambas envolvidas com a questão do feminismo." ARÊAS, Vilma. Op. Cit., 2013, p. 242.

${ }^{121}$ HUGO, Victor. Prefácio a Angelo. In: HUGO, Victor. Obras completas. Trad. Hilário Correia. São Paulo: Editora das Américas, 1960, vol. XXXIX, p. 153. 
Dias, provavelmente dialogando com o Prefácio de Cromwell, esclarece que o drama seria o resumo da tragédia e da comédia. Esse esclarecimento argumenta a favor do uso simultâneo da prosa e do verso, adequando-os a cada cena, a cada sentimento. Não só a ideia da súmula entre os dois gêneros serve de argumento para tal defesa, mas também o exemplo de Shakespeare. Além disso, Dias entende que a prosa de Herculano é poética, bem como a poesia de Garrett tem aspectos da prosa. O poeta insta para que haja inovação nesse sentido, ou seja, a expressão, prosa ou verso, deve adequar-se ao pensamento no âmbito de um mesmo drama.

\begin{abstract}
Assim, pois o drama resume a comédia e a tragédia. Ora, se a tragédia se não pode conceber sem verso, assim também a comédia sem prosa não pode existir perfeita. Para prova disto basta que reflitamos que o melhor autor cômico do mundo, o célebre Molière, foi o primeiro que, não sem dificuldade, introduziu a prosa no teatro francês. Antes dele, até os bons burgueses se envergonhavam em falar a linguagem do povo e dos sábios. Patearam-no, creio eu, bem que Racine seguiu o seu exemplo. Porém, primeiro que estes excelentes dramaturgos, outro que ainda não foi excedido em arranjo e sublimidade, o afamado Shakespeare, que inventou o drama descrevendo fielmente a vida, já havia achado a verdadeira linguagem da comédia usando nela a prosa. Nos seus dramas ou crônicas foi Shakespeare consequente consigo, usou simultaneamente da prosa e do verso, porque simultaneamente criava em ambos os gêneros. Nós por que o não havemos de imitar? Quando ele quer exprimir uma coisa vulgar ou uma chocarrice, usa da prosa; quando quer exprimir um sentimento nobre ou uma exaltação do espírito, usa do verso, e não só do verso heroico como de todos os mais da língua inglesa $[\ldots]^{122}$
\end{abstract}

É interessante notar que Dias também dialoga com Hugo quando fala sobre a escolha da expressão (verso, prosa ou ambas) ideal para o drama, mas este inicialmente preferirá o verso, embora ache possível, como em Shakespeare, utilizar as duas formas. Vale a pena ressaltar que à linguagem romântica coube a tarefa de diminuir a distância entre linguagem oral e escrita. Nesse sentido, o verso hugoano exprime tudo, o alto e o baixo, diferentemente da linguagem seletiva do neoclassicismo ${ }^{123}$.

$\mathrm{O}$ verso é a forma ótica do pensamento. Eis porque convém sobretudo à perspectiva cênica. Composto de uma certa maneira, comunica seu relevo a coisas que, sem ele, passariam insignificantes e vulgares. Torna mais sólido e mais fino o tecido do estilo. É o nó que prende o fio. É o cinto que sustenta a roupa e lhe dá todas as suas pregas. ${ }^{124}$

122 DIAS, Gonçalves. Prólogo a Leonor de Mendonça. Op. Cit., 907.

123 PRADO, Décio de. O teatro romântico: a explosão de 1830. In: GUINSBURG. J., (Org.). $O$ Romantismo. São Paulo: Perspectiva, 1985, p. 175.

${ }^{124}$ HUGO, Victor. Op. Cit., 2004, p.76. 
Uma outra fração da reforma se inclinaria para o drama escrito ao mesmo tempo em prosa e em verso, como fez Shakespeare. Esta maneira tem suas vantagens. Poderia, no entanto, haver disparidade nas transições de uma forma a outra, e quando um tecido é homogêneo, é bem mais sólido. Além disso, que o drama esteja escrito em prosa, que esteja escrito em verso, isto não é senão uma questão secundária. A categoria de uma obra deve ser fixada não segundo sua forma, mas segundo seu valor intrínseco. Nas questões deste tipo, só há uma solução; só há um peso que pode fazer inclinar a balança da arte: é o gênio. ${ }^{125}$

Gonçalves Dias, atento às inovações europeias, reflete sobre elas e acolhe aquelas que lhe parecem condizentes com a sua poética. Dias apropria-se do prefácio hugoano, mas os aplica em diferentes situações. Victor Hugo, através do exemplo do "vamos jantar", transcrito a seguir, comenta a coesão entre o sublime e o grotesco no drama; um exemplo parecido em Dias serve para mostrar a necessidade de alternância entre prosa e verso de acordo com o sentimento e situação em cena. Note-se que a simultaneidade da prosa e do verso propalada por Dias pressupõe de antemão a harmonia entre os opostos, o sublime e o grotesco, numa mesma obra:

No drama, tal como se pode, se não executá-lo, pelo menos concebê-lo, tudo se encadeia e se deduz assim como na realidade. O corpo representa o seu papel como a alma; e os homens e os acontecimentos, postos em jogo por este duplo agente, passam alternadamente, cômicos e terríveis, algumas vezes terríveis e cômicos, ao mesmo tempo. Assim dirá o juiz: 'Condenado à morte, e vamos jantar! ${ }^{126}$

Suponhamos que Shakespeare apresentava em cena uma daquelas personagens que ele comprazia em enfeitar com todas as flores do seu gênio, Hamlet, Lear, Otelo ou Macbeth. Se no meio de um daqueles seus monólogos, em que a beleza do verso rivaliza com a sublimidade do pensamento, lhe fosse preciso apresentar também um importuno, um servo, por exemplo, que viesse a chamar seu senhor à mesa, com certeza que ele não poria versos na boca do vilão, nem se cansaria em imaginar uma perífrase para dizer em versos: 'O jantar está posto'. Ele diria isto como vulgarmente se diz, como todos os dias o ouvimos, sem adorno mal cabido e sem majestade forçada. ${ }^{127}$

A fusão dos gêneros hugoana evidenciada na relação entre o grotesco e o sublime também é discutida no prefácio de Angelo (1835), nele Hugo afirma que sua peça não é totalmente aristocrática nem totalmente doméstica para que seja, ao mesmo tempo, grande e verdadeira. A obra não é tragédia nem comédia, não privilegia apenas o estilo alto, mas também o médio. Enfim, ele descreve o que seria o cerne do drama, a

\footnotetext{
${ }^{125}$ Idem, ibidem, p. 79

${ }^{126}$ Idem, ibidem, p. 48

${ }^{127}$ DIAS, Gonçalves. Prólogo a Leonor de Mendonça. Op. Cit., p. 908. Grifos meus.
} 
mistura dos gêneros. Essa integração é aquiescida por Gonçalves Dias e empreendida na obra em questão de forma mais evidente com a inclusão e nobilitação da cena familiar na casa do Velho Alcoforado ${ }^{128}$, a qual se contrapõe às cenas que mostram a artificialidade da relação entre o duque e Leonor. A célebre cena na casa de Manuel Alcoforado tem como escopo elevar o que era considerado pertinente ao estilo médio, pois, de acordo com a divisão clássica, ela pertenceria à comédia. O objetivo aqui não é fazer rir.

\begin{abstract}
No começo do teatro moderno havia duas obras possíveis: a tragédia, que cobria suas espáduas com manto de púrpura, e a comédia, que pisava o palco cênico com os seus sapatos burgueses ${ }^{129}$; era assim, porque a tragédia andava pelos grandes, enquanto que a comédia se entretinha com os pequenos, e ainda assim com o que nestes havia de mais cômico e risível. Hoje, porém, a comédia e a tragédia fundiram-se numa só criação. E de feito, se atentamente examinarmos as produções de hoje, que chamamos dramas, notaremos que ainda nas mais líricas e majestosas há de vez em quando certa quebra de gravidade, sem a qual não há tragédia. Notaremos também que essa quebra provém de ordinário de uma cena da vida doméstica, o que verdadeiramente pertence à comédia. Aquela cena, por exemplo, do segundo ato de Lucrécia Bórgia, ${ }^{130}$ entre Lucrécia e o duque de Ferrara, é um bosquejo da vida íntima, é um fato que, mais ou menos modificado, tem lugar em toda parte no conchego da família; é uma cena que pertence à comédia, porque não é da sua essência fazer rir. Descreva ela fielmente os costumes, e a arte ficará satisfeita. $^{131}$
\end{abstract}

A mistura de estilos e a admissão do que era considerado vulgar como matéria para o gênero sério são decorrentes do conceito de historicismo que permeia a visão romântica. Essa nova atitude não julga mais as sociedades e as artes com base em uma concepção inalterável, generalizadora e abstrata. A história não se baseia nas ações exemplares de uma casta da sociedade, ela apreende todas as camadas e expressões desse grupo. O peculiar e o móvel, que atestam o evolucionismo do homem, passam a ser valorizados em detrimento de uma ordem inalterável e abstrata.

\footnotetext{
${ }^{128}$ Quando Dias compara as personagens de sua obra no prólogo, fica clara a ideia de que o amor e a condescendência que permeiam as relações na casa de Manuel Alcoforado são valorizados. "Há realmente contraste entre o duque poderoso e o modesto pai de família, entre o palácio suntuoso e a habitação singela: o que há de mais naquela falta nesta, o que nesta é necessário, falta naquele. $\mathrm{O}$ velho não quer senão viver e morrer entre os seus filhos, e o duque foge com prazer do seu palácio para viver uma semana na sua ermida do Convento do Bosque, ou com os seus capelães da Serra de Ossa. Assim é com razão, porque o velho tem para si que melhor que a sua vida só a bem-aventurança, enquanto que para o duque fora verdadeira bem-aventurança viver a vida tranquila do velho.” Idem, ibidem, p. 906.

${ }^{129}$ É interessante notar a conformação da família de Alcoforado como representantes burgueses na obra e, portanto, como personagens cômicos, baseando-se na descrição que Gonçalves Dias faz do Velho Alcoforado (e de sua morada, que é singela) qualificando-o como "modesto pai de família".

${ }^{130}$ Note-se que o exemplo dado por Gonçalves Dias confirma o diálogo com Victor Hugo.

${ }^{131}$ DIAS, Gonçalves. Prólogo a Leonor de Mendonça. Op. Cit., p. 907.
} 
O modelo shakespeariano também contribuiu para a teoria sobre a necessidade da harmonia entre o sublime e o grotesco hugoana e a importância do drama para a sociedade moderna: "Shakespeare, é o drama; e o drama, que funde sob um mesmo alento o grotesco e o sublime, o terrível e o bufo, a tragédia e a comédia, o drama é o caráter próprio da terceira época de poesia, da literatura atual." ${ }^{132}$ Para Naugrette ${ }^{133}$, o grotesco em Victor Hugo serve para dessacralizar os valores, minar as certezas e instaurar a dúvida. Nesse sentido, uma mesma personagem pode agir de forma sublime e grotesca ou uma cena pode conter traços cômicos e ser, ao mesmo tempo, sublime, evitando-se, assim, a polarização maniqueísta. Um exemplo desse tipo de personagem em Gonçalves Dias é o jovem Alcoforado que perpassa a obra entre cenas típicas da comédia e da tragédia. Dessa forma, a imbricação entre os opostos entrevistos na vida conseguiria tornar a arte verdadeira, não no sentido de cópia da natureza, mas numa acepção estética ${ }^{134}$. O drama seria um espelho de concentração que fortalece a visão do todo por meio da arte. A verdade para Hugo seria a arte que provoca a emoção, a qual, por sua vez, gera a tomada de consciência.

Le théâtre n'est pas le pays du réel: il y a des arbres de carton, des palais de toile, un ciel de haillons, des diamants de verre, de l'or de clinquant, de fard sur la pêche, du rouge sur la joue, un soleil qui sort de dessous terre. C'est le pays du vrai: il y a des cœurs humains sur la scène, des cœurs humains dans la coulisse, des cœurs humains dans la salle. ${ }^{135}$

Vale destacar que essa proposição de Hugo se coaduna com a interpretação romântica da obra teatral de Shakespeare. Nessa acepção, nas obras do dramaturgo inglês, que prescidiam de regras, haveria uma expressão verdadeira da natureza, pois nelas coexistiriam "o bem e o mal, o lado mais elevado e o lado mais baixo do ser

132 HUGO, Victor. Op. Cit., 2004, p. 40.

${ }^{133}$ NAUGRETTE, Florence. Le théâtre romantique: histoire, écriture et mise en scène. Paris: Éditions du Seuil, 2001, 2001, p. 280-281.

134 "O cristianismo conduz a poesia à verdade. Como ele, a musa moderna verá as coisas com um olhar mais elevado e mais amplo. Sentirá que tudo na criação não é humanamente belo, que o feio existe ao lado do belo, o disforme perto do gracioso, o grotesco no reverso do sublime, o mal com o bem, a sombra com a luz. [...] É então que, com o olhar fixo nos acontecimentos ao mesmo tempo risíveis e formidáveis, e sob a influência deste espírito de melancolia cristã e de crítica filosófica que notávamos há pouco, a poesia dará um grande passo, um passo decisivo, um passo que semelhante ao abalo de um terremoto, mudará toda a face do mundo intelectual. Ela se porá a fazer como a natureza, a misturar nas suas criações, sem entretanto confundi-las, a sombra com a luz, o grotesco com o sublime, em outros termos, o corpo com a alma, o animal com o espírito, pois o ponto de partida da religião é sempre o ponto de partida da poesia. Tudo é profundamente coeso.” HUGO, Victor. Op. Cit., 2004, p. 27.

${ }^{135}$ HUGO, Victor. Le tas de Pierre (1830-1833) in: Oeuvres complètes. Paris: Club Français du Livre, t. IV, p. 948 apud NAUGRETTE, Florence, Op. Cit., p. 250. 
humano, os impulsos e sentimentos, ao lado da razão e dos argumentos. ${ }^{136 " ~ E s s a ~}$ capacidade de expressar a natureza humana ia de encontro à artificialidade do teatro neoclássico e à limitação da arte como um paradigma de virtude. Além disso, como observara Herder, o bardo inglês representa com fidelidade a natureza de seu povo e de seu tempo. A defesa de um teatro que privilegia a naturalidade e a emoção em detrimento de regras baseia-se na leituras pré-românticas e românticas da dramaturgia shakespeariana, sobretudo das tragédias. ${ }^{137}$

Para Auerbach, o movimento romântico francês tomou o princípio da mistura de estilos como divisa, pois evidenciava o contraste com os temas e linguagem neoclássicos. Mas ao fazer o contraponto entre dois polos opositivos que não tem relação com o real, o sublime e o grotesco, Hugo afasta-se da representação objetiva da vida e concentra-se nas contradições éticas e estilísticas de forma veemente tornando sua expressão poderosa na tentativa de formar uma totalidade a partir do díspar ${ }^{138}$.

Ao insistir na inovação do teatro por meio do uso concomitante da prosa e do verso $^{139}$, Dias também acaba por avizinhar a poesia da música, descrevendo como algumas falas de teor poético em Leonor de Mendonça soariam como diferentes instrumentos de uma orquestra sugerindo uma aproximação do drama com a ópera. Esse comentário atesta também, como observou Arêas ${ }^{140}$, a sensibilidade que o autor possuía para o gênero lírico, que fica bastante explícito no excerto do folhetim escrito por ele:

Em toda a parte as podemos ver separadas, mas no teatro queremo-las juntas. $\mathrm{E}$ queremos mais, pois queremos ver com elas a arquitetura, a ótica, a mecânica.

O teatro deve ser uma reunião de belas artes, a poesia deve ser compreendida para reconhecermos os pensamentos do seu autor.

A música, para nos revelar esses influxos divinos, que nos encantam, que nos eletrizam.

\footnotetext{
136136 SÜSSEKIND, Pedro. Shakespeare: o gênio original. Rio de Janeiro: Jorge Zahar Ed., 2008, p. 97.

${ }^{137}$ Idem, passim.

${ }^{138}$ ROSENFELD, Anatol. Teatro Moderno. 2. ed., São Paulo: Perspectiva, 1997, p. 81.

${ }^{139}$ A discussão sobre o uso do verso e da prosa é retomada por Gonçalves Dias em seus folhetins teatrais, como no excerto a seguir em que pondera sobre como o verso poderia enriquecer o sentido de Hernani: "Sentimos, porém, que ele [Victor Hugo] alguma vez não empregasse a rima. Cenas há de Victor Hugo tão delicadas e mimosas, que parecem incompletas se não são rimadas, tais são neste drama todos os diálogos entre Hernani e Dona Sol; não é por que a rima seja, como diz Stäel, uma saudade e uma esperança ao mesmo tempo; o verso que temos, diz ela, nos faz desejar o que lhe corresponde, e este verso nos recorda o primeiro; é como uma aspiração do futuro e como uma recordação do passado. Hernani e Dona Sol são duas vozes que se adivinham; quiséramos, pois, que a rima significasse a harmonia daquelas almas, que acontecesse com ela o que muitas vezes acontece na cantoria: - acabar uma voz a nota coeçada por outra antes dela - o que muitas vezes acontece na vida entre pessoas que se amam - rematar uma delas o pensamento que a outra começa apenas a enunciar.” DIAS, Gonçalves. O Correio da Tarde. n. 158, 21 de jul. de 1848. In: GIRON, Luís Antônio. Op. Cit., p. 578.

${ }^{140}$ ARÊAS, Vilma. Op. Cit., 2013, p. 230.
} 
A pintura, para nos levar aos tempos e os lugares que se representa $(\ldots)^{141}$

Outrossim, é curioso notar que Dias não se esquece de comentar o que seria do âmbito da melopeia, se pensarmos nos elementos da tragédia. Décio de Almeida Prado assevera que com a inclusão dos versos o efeito pretendido pelo poeta compara-se ao da ária após os recitativos na ópera italiana, quando há um aumento do efeito lírico. Podese inferir com base na comparação feita pelo crítico que o dramaturgo brasileiro tenha se inspirado, direta ou indiretamente, na Norma de Bellini, ópera que alcançou grande êxito em Portugal, sendo interpretada no Teatro S. Carlos de 1837 até 1844, casa de espetáculos que Dias frequentou com assiduidade ${ }^{142}$.

No Brasil, Norma foi representada inúmeras vezes refletindo o atraso e o descompasso com as novidades das produções europeias, questão abordadada de forma veemente por Dias em seus folhetins de crítica teatral: “(...) - Norma! - Ainda? Ainda. Mais Norma! - Ainda? - Resistem alguns recalcitrantes. - Norma de enfiada! Morreram todos? - Resta um. - Pois Norma com ele até que morra!". Ainda no mesmo folhetim, Dias novamente cita a repetição de Norma como exemplo de escassez de repertório do S. Pedro e faz outras críticas revelando a debilidade do teatro nacional:

\begin{abstract}
Por isto pagamos uma companhia que não ouvimos, por isso temos quarentena de Norma, o que tanto vale como dizer-se quaresma de bacalhau por isso alteiam-se os preços e não há casa e vendem-se bilhetes de entrada a 160 réis cada um: transferem-se benefícios sem que se saiba o porquê, dãonos vestais com hábito de freiras, o que é vender gato por lebre, templários que são frades de S. Domingos, uma sala de orgia para uma sala de armas, com cíatos em vez de espadas, bufetes em vez de troféus; vemos trajes improvisados nos bastidores, vistas fantasmagóricas, óperas mal ensaiadas, mal executadas; e por fim um ator que é baixo, barítono e tenor, como se ele por si só fosse o resumo, o compêndio de uma companhia de canto. ${ }^{143}$
\end{abstract}

A obra belliniana, considerada "o marco do Romantismo nascido do neoclassicismo"144, se caracteriza pela carga de sentido que o acompanhamento da orquestra ajuda a construir unindo-se aos gestos e palavras das personagens.

\footnotetext{
${ }^{141}$ DIAS, Gonçalves. "O teatro de São Pedro”. In: GIRON, Luís Antônio. Op. Cit., p. 444.

${ }^{142}$ Segundo Giron, Gonçalves Dias "assistiu à temporada lírica de 1841 no teatro de São Carlos em Lisboa e às representações das peças românticas de Almeida Garrett e Alexandre Herculano em Coimbra...”. GIRON, Luís Antônio. Op. Cit., p. 10.

${ }^{143}$ Idem, Ibidem, p. 513 e 514, respectivamente.

144 MASO, Gonzalo Badenes. Introdução. In: BELLINI, Vincenzo. Norma. Libreto italiano de Felice Romani baseado no drama homônimo de Alexandre Soumet. Lisboa: Editorial Notícias. Introd., análise e comentários Gonzalo Badenes Maso, s/d, p. 11.
} 
A plasticidade e flexibilidade do comentário orquestral ultrapassam o simples acompanhamento. A orquestra belliniana não só sublinha os gestos e características da heroína, como se pode afirmar que 'lê' o seu pensamento. A tonalidade sombria do Ré menor mantém-se ao longo de toda a cena. O tempo varia entre o allegro assai moderato e um desesperado allegro agitato no momento em que Norma, no auge da loucura, está prestes a consumar o infanticídio. Mas o pensamento do que esta monstruosidade representa para uma mãe [...] faz com que detenha o punhal e, pouco depois, recuperando a sua classe e majestade, irrompe num sereno mas enérgico 'Olá, Clotilde!', diluindo-se na orquestra a tensão acumulada. ${ }^{145}$

Dias também queria assim proceder conforme o seu comentário no "Prólogo"146. No entanto, consciente da dificuldade de um novato impor essa novidade, o autor de Primeiros Cantos optou pela prosa (sem acompanhamento musical) que não deixa de se tornar poética nos momentos de efusão emocional ${ }^{147}$. Outro ponto que permite a aproximação entre Norma e Leonor de Mendonça é a pretensão dos dois autores de infundir grande carga lírica numa cena em que a protagonista luta com os seus desejos em frente ao leito dos filhos.

Norma é uma sacerdotisa druida que se apaixona por Pollione, um romano com quem tem dois filhos. Traída pelo romano, ela fica dividida entre o desejo de vingança e o amor pelos filhos. Norma é tentada pela ideia de cometer infanticídio e, assim, ferir o pai, bem como impedir que as crianças tornem-se escravas. A sacerdotisa se detém no último instante, com o punhal em mãos, em frente ao leito dos filhos. A cena que remete a obra italiana em Leonor não tem a mesma tragicidade, ou melhor, pode-se dizer que a ideia da ópera é distendida no drama. O trecho mais importante em termos de comparação seria o momento em que Leonor, dividida entre o dever e o desejo, declara seu amor a Alcoforado à cabeceira dos filhos, o alertando, porém, que, depois da confissão, eles não poderiam mais se ver. Já na primeira cena do Quadro V do III Ato, a duquesa alude ao infanticídio, argumentando que se tivera uma filha seria melhor

\footnotetext{
${ }^{145}$ Idem, Ibidem, p. 26.

146 "Quando, no quarto quadro, a duquesa começa a exaltar-se com o som de suas próprias palavras, fazendo subir de ponto a impaciência do duque, a cólera deste, instigado pela demora, devia trovejar-lhe dos lábios em versos robustos, e o espectador compreenderia otimamente a razão de súbita mudança. Daqui até ao fim do quadro continuaria sempre a poesia. A voz de Alcoforado suplicando a vida da duquesa seria como uma harpa em uma orquestra, a voz da duquesa como um acorde mavioso, e a voz do duque e os da sua comitiva como um acompanhamento fúnebre e pavoroso. Não sei o que diga; mas está me parecendo que, se quando a plateia esperasse ansiosa o desfecho de uma cena, de um ato, ou do drama, mudassem os atores repentinamente de linguagem, e trovejasse ao mesmo tempo o verso nos lábios dos atores e a música em todos os instrumentos da orquestra, haveria na plateia tal fascinação que devia esmorecer por fim num bater prolongado de palmas e num estrugir acalorado de bravos. Mas não é da música que tratamos agora.” DIAS, Gonçalves. Prólogo a Leonor de Mendonça. Op. Cit., p. 909.

${ }^{147}$ PRADO, Décio de Almeida. Op. Cit., 1996, p.108-111.
} 
matá-la para que a criança fosse livre. Na sequência, na cena IV, ela se despede dos seus rebentos e reflete sobre a sorte que os aguarda após a sua morte.

Outro tópico discutido no Prólogo é a diferença entre Otelo e d. Jaime, deixando clara a intertextualidade com a obra do dramaturgo inglês. Segundo Dias, a personagem shakespeariana ama e, por isso, é ciosa. D. Jaime não ama porque o seu casamento é uma união contratual que o impede de seguir sua aptidão religiosa. $\mathrm{O}$ duque não se nega a viver depois do assassinato como o faz Otelo.

\begin{abstract}
O duque é nobre e desgraçado; da nobreza tem orgulho, da desgraça a desconfiança, e do tempo a vida e a superstição. O duque é cioso, e, notável coisa! É cioso não porque ama, mas porque é nobre. É esta a diferença que há entre Otelo e D. Jaime. Otelo é cioso porque ama, D. Jaime porque tem orgulho. Ambos são crédulos e violentos, mas a credulidade de Otelo formase e caminha a passos lentos, porque o seu amor duvida; a sua violência, relevem-me a expressão, é vagarosa e caminha com a terrível majestade de um vulcão. O duque crê quanto basta ao bom senso de qualquer homem, e a sua violência é precipitada, por que ele não se interessa com a inocência de sua esposa. Otelo mata a Desdêmona, mas chora antes de a matar e depois de a ter morto; o duque mata a Leonor de Mendonça, mas sem lágrimas, porque o orgulho não as tem. ${ }^{148}$
\end{abstract}

As diferenças entre d. Jaime e Otelo são essenciais para a formação da personagem gonçalvina, bem como as suas afinidades, sobretudo no que concerne à questão da passionalidade ${ }^{149}$. O duque de Bragança age movido pelo pathos $^{150}$, suas ações são irracionais, sua presença causa medo e suas preocupações são mundanas, como o desejo de vingança e o prestígio social. Todas essas características associam a figura de d. Jaime ao grotesco opondo-o ao jovem Alcoforado, pois suas ações privilegiam questões espirituais e não sensíveis.

\footnotetext{
${ }^{148}$ DIAS, Gonçalves. Prólogo a Leonor de Mendonça. In: Op. Cit., p. 905.

149 Werkema assinala que "Otelo, o nobre mouro arrastado pelas paixões, configura com perfeição aquilo que seria o 'grotesco sublime' do Romantismo, em sua mistura de características idealizadas e corpóreas - elevação e fisiologia -, grande epítome romântica que simboliza aqui o gênero híbrido.” WERKEMA, Andrea Sirihal, Op. Cit., p. 200.

150 Segundo a citação a seguir, na Poética, Aristóteles utiliza o termo pathos relacionando ora com o efeito das ações sobre as personagens, ora com o efeito que a tragédia suscita nos espectadores. "Pathos, too, in Aristotle has a wide range of meanings. In its broadest sense, it may mean any effect suffered passively by a subject, including for example sense perceptions as opposed to voluntary actions. In the Poetics, too, Aristotle uses pathos at least in two different senses. In one sense pathos there means a strong and painful physical or mental suffering or affliction, forming thus one of the potential constituent parts of a tragic mythos or plot. Yet on the other hand, in the Poetics pathos is also, in the sense of a strong and powerful emotion, the pivotal qualitative effect of any kind of poetry, which may ultimately result in the effect of its own catharsis, i.e. either purgation or purification." KRAUS, Manfred. Aristotle on the arts of the spoken word: correlations between his Rethoric and Poetics. In: PEREIRA, Belmiro Fernandes; VÁRZEAS, Marta (Orgs.). Retórica e Teatro. A palavra em ação. Porto: U. Porto, 2010, p. 101.
} 
[...] com efeito, na poesia nova, enquanto o sublime representará a alma tal qual ela é, purificada pela moral cristã, ele [grotesco] representará o papel da besta humana. O primeiro tipo, livre de toda mescla impura, terá como apanágio todos os encantos, todas as graças, todas as belezas; é preciso criar um dia Julieta, Desdêmona, Ofélia. O segundo tomará todos os ridículos, todas as enfermidades, todas as feiúras. Nesta partilha da humanidade e da criação, é a ele que caberão as paixões, os vícios, os crimes, é ele que será luxurioso, rastejante, guloso, avaro, pérfido, enredador, hipócrita. ${ }^{151}$

Eugênio Gomes chama a atenção para a similitude entre Otelo e Leonor de Mendonça no sentido de que em ambas as obras o sentimento de amor é confundido com o de compaixão.

\footnotetext{
Em um artigo sobre o drama Leonor de Mendonça, tivemos o ensejo de mostrar, até certo ponto, quão acentuado era o sentimento de piedade em Gonçalves Dias. Sua impregnação do 'Otelo', revelada por aquela peça, tinha a ternura compassiva como um de seus indícios mais sensíveis ${ }^{152}$
}

Com efeito, em ambas as obras o sentimento de afeto das duas protagonistas em relação aos homens parece aproximar-se mais da compaixão que da paixão. Desdêmona interessa-se por Otelo após ouvir o quanto ele sofrera em seus caminhos. "Ela me amou porque passei perigos, / E eu a amei porque sentiu piedade."153 A duquesa, apesar de temer o duque, apieda-se de seu marido, mesmo quando ele age duramente, por ter sofrido muito quando criança. D. Jaime tinha quatro anos de idade quando seu pai, acusado de traição por d. João II, foi decapitado em Évora. O futuro duque de Bragança é então acolhido por d. Isabel em Castela. Em 1497, no reinado de d. Manuel, d. Jaime retorna a Portugal. Na peça, Gonçalves Dias acrescenta ter sido ele, juntamente com o irmão, envenenado. Ele teria sobrevivido e o irmão perecido. Em relação à Alcoforado, a duquesa também exprime um sentimento de gratidão e comiseração: “(...) eu vos amo, porque vos devo a vida, porque não tendes mãe, eu vos quero servir de mãe porque sofreis, e eu quero ser vossa irmã. É um amor compassivo e desvelado, que poderá ser reprovado na terra, mas que eu não creio que o seja no céu." 154 Vale a pena destacar que Kitty Bell, personagem do drama Chatterton de

\footnotetext{
${ }^{151}$ BERRENTINI, Célia. Introdução. In: HUGO, Victor. Op. Cit., 2004, p. 9.

152 GOMES, Eugenio. Visões e revisões. Rio de Janeiro: Ministério da Educação e Cultura; Instituto Nacional do Livro, 1958, p. 54. Infelizmente não tivemos acesso ao texto mencionado por Gomes, mas o excerto aqui citado dá conta de demosntrar que o crítico nota em Gonçalves Dias e especialmente em Leonor de Mendonça a acentuada presença do sentimento de piedade.

${ }^{153}$ SHAKESPEARE, William. Otelo, o mouro de Veneza. Trad. Bárbara Heliodora, Rio de Janeiro: Nova Fronteira, 2011, p. 31.

${ }^{154}$ DIAS, Gonçalves. Op. Cit., p. 951.
} 
Vigny, também se interessa pelo poeta, pois se compadece de sua situação de privação e de seu sofrimento.

Rhinow em sua tese Visões de Otelo na cena e na literatura dramática nacional do século XIX destaca a descendência direta de Leonor de Mendonça da obra shakespeariana num tempo em que a versão de Ducis ainda prevalecia na cena teatral brasileira. A autora estabelece então alguns paralelos entre as duas obras apontando aproximações e distanciamentos. Segundo a tese, há passagens em Gonçalves Dias que explicitamente remetem ao texto shakespeariano ${ }^{155}$, como aquela em que o duque denomina Leonor de "minha bela guerreira"156, pois o mesmo epíteto é dado à Desdêmona pelo marido Otelo ${ }^{157}$. No que concerne ao enredo, Rhinow assinala a utilização de um objeto como elemento comprometedor das protagonistas, o lenço de Desdêmona e a fita de Leonor. A estudiosa observa também que ambas as personagens intercedem junto aos maridos em benefício do destino dos supostos amantes: Leonor pede ao duque que Alcoforado seja enviado às lides na África ${ }^{158}$; Desdêmona intervém em favor de Cássio quando o marido Otelo decide demiti-lo ${ }^{159}$. Ademais, há analogia no fato de a revelação da traição das esposas ser feita por um servo considerado muito confiável, Fernão e Iago, embora a diferença entre essas duas personagens seja crucial para o desenvolvimento das peças. O escopo de Iago não avulta da fidelidade como em Fernão. Já as serviçais Paula (Leonor de Mendonça) e Emília (Otelo: o mouro de Veneza) seriam similares no que concerne à fidelidade e à imprudência. Com base no estudo de Jacobbi, Rhinow assinala que Otelo é apenas um pano de fundo para o drama gonçalvino, pois neste a personagem principal é Leonor e o duque lhe serve como contraponto. Na obra de Shakespeare, é Desdêmona que serve como contraponto para o protagonista Otelo.

Esta, sim, vai além de Desdêmona: da desbotada e contraditória Desdêmona. $\mathrm{Na}$ tragédia de Shakespeare, o imenso, compacto Otelo encontra na mulher um contraponto; no drama do poeta brasileiro, é Dom Jaime (apesar de toda intensidade) que serve de contraponto a Leonor. ${ }^{160}$

\footnotetext{
155 RHINOW, Daniela Ferreira Elyseu. A Desdêmona ambígua: Leonor de Mendonça, de Gonçalves Dias. In: Visões de Otelo na cena e na literatura dramática nacional do século XIX. vol. I. São Paulo, 2007, Tese (Doutorado em Literatura Brasileira), Universidade de São Paulo, p. 164-175.

${ }^{156}$ DIAS, Gonçalves. Op. Cit., p. 923.

${ }^{157}$ SHAKESPEARE, William. Op. Cit., p. 47.

${ }^{158}$ DIAS, Gonçalves. Op. Cit., p. 921.

${ }^{159}$ SHAKESPEARE, William. Op. Cit., p. 73-74.

${ }^{160}$ JACOBBI, Ruggero. Op. Cit., p. 82-3.
} 
Por fim, Daniela Rhinow assevera a principal distinção entre as obras. Leonor é inocente, mas não ingênua como Desdêmona. A ambiguidade dos sentimentos da protagonista gonçalvina e sua inclinação ao adultério, ainda que não consumado, faz toda a diferença. Leonor interessa-se por Alcoforado conquanto não faça nada que possa torná-la culpada perante os homens ${ }^{161}$.

Além do diálogo explícito com o Otelo shakespeariano, podemos atentar para outras concepções do teatrólogo inglês presente em Gonçalves Dias. É preciso lembrar que as lições shakespearianas foram entusiasticamente defendidas pelos pré-românticos e românticos alemães. Lessing, por exemplo, contestava o neoclassicismo propagado pela França argumentando que assim como não havia um teatro alemão, não havia um teatro francês, pois este era uma cópia do teatro grego, e, aqueles, uma cópia da cópia. Por essa razão, ele apreciava o gênio poético de Shakespeare que criara suas tragédias independentes do modelo da Grécia Antiga ${ }^{162}$. Lessing destaca, principalmente, a humanidade, a compreensão do sofrimento humano e a visão arguta da sociedade em Shakespeare.

\begin{abstract}
Os sofrimentos que afligem o herói não surgem miraculosamente, por obra divina: resultam de atos humanos, ainda que por vias indiretas. A história de cada peça não consiste apenas de atos humanos, mas estes são o fator predominante, embora o acaso também entre em cena... Shakespeare mostra um herói que vive as consequências de atos seus e de outros, ainda que nem sempre seja responsável moralmente, culpado, enfim, no sentido mais comum do termo. ${ }^{163}$
\end{abstract}

Jacobbi chama a atenção sobre essas mesmas características em Leonor de Mendonça: a humanização das personagens não como uma abstração psicológica ou moralística, mas inserida em uma dada realidade histórica ${ }^{164}$, particularidade que G. Dias faz questão de esclarecer no Prólogo. Para os românticos, voltamos a assinalar, Shakespeare representaria o paradigma do gênio, pois fora capaz de criar personagens de forma orgânica, de maneira análoga à natureza. Respeitando as lições de Shakespeare, os caracteres gonçalvinos são complexos, ou seja, eles não são psicologicamente planos e podem agir de maneira elevada ou baixa, ou seja, como uma personagem trágica ou cômica dependendo da situação. Além disso, essas figuras

\footnotetext{
${ }^{161}$ RHINOW, Daniela Ferreira Elyseu. Op. Cit., p. 164-75.

162 DUARTE, Pedro. Estio do tempo: Romantismo e estética moderna. Rio de Janeiro: Zahar, 2011, p. 104.

${ }^{163}$ MORETO, Fúlvia. L.; BARBOSA, Sidney (Orgs.), Aspectos do teatro ocidental. São Paulo: UNESP, 2006 , p. 59.

${ }^{164}$ JACOBBI, Ruggero. Op., Cit., p. 76.
} 
dramáticas são apresentadas inseridas num determinado contexto, o que também interfere no desenvolvimento do conflito.

No prefácio, além de comparar o duque a Otelo aclarando a intertextualidade com o bardo inglês, Dias também compara o Bragança ao velho Alcoforado e ambos são considerados severos. O primeiro porque é sensível, o segundo, porque ama; ou seja, a severidade de d. Jaime advém de seu egoísmo; a sua história fez dele alguém apático. D. Jaime não ama. Já o velho Alcoforado só é severo para garantir a integridade física e moral daqueles que estima. A diferença entre as personagens é enfatizada com base no espaço concernente a cada uma delas, o castelo do duque e a simplória casa do velho Alcoforado: numa, as relações se pautam na etiqueta de corte ${ }^{165}$, na outra, os sentimentos são expressos de forma mais livre.

Gonçalves Dias não descuida da construção desse contraste, as falas e atos das personagens convergem para tal caracterização. O prefácio demonstra a preocupação do autor tanto com a ação quanto com a construção das personagens, aliás, esses dois elementos são estreitamente interdependentes. Dias afirma que a ação nasce do embate entre personagens, por isso, há a necessidade de delinear os caracteres de modo a justificar as ações e o enredo. Em sua análise do drama, Esslin ${ }^{166}$ afirma que: "Quanto mais completamente um dramaturgo imagina uma situação e os personagens que a vivem, mais perto a peça chegará da complexidade e ambivalência da vida real."

A crítica à inibição da liberdade de expressão é o tema que conclui o Prólogo de Leonor de Mendonça aproximando-o, nesse trecho, do prefácio-manifesto ${ }^{167}$. Reservar para o final a admoestação à censura parece não ser uma escolha arbitrária e ressalta 0 anseio por liberdade, desejo que, além de ser inerentemente romântico e coetâneo, vai de encontro às práticas do Conservatório Dramático Brasileiro.

\footnotetext{
165 “No âmbito da etiqueta, eles [os cortesãos] não se reuniam 'em função de uma coisa'. Sua existência e a manifestação de seu prestígio, o distanciamento em relação aos que ocupavam uma posição inferior, o reconhecimento dessa distância pelos que ocupavam uma posição superior, tudo isso era um objetivo suficiente por si mesmo. Mas era na etiqueta que esse distanciamento como objetivo em si tinha sua expressão mais perfeita. Constituía-se assim um desempenho da sociedade de corte no qual as chances de prestígio estavam alinhadas segundo uma hierarquia. E os atores demonstravam que detinham tais chances, tornando visível, com isso, a relação distanciada que simultaneamente unia e distinguia tais indivíduos entre si, e conservando assim, na própria maneira de atuar, a hierarquia presente para todos, o valor corrente da corte que conferiam uns aos outros." ELIAS, Norbert. A sociedade de corte: investigação sobre a sociologia da realeza e da aristocracia de corte. Trad. Pedro Süssekind. Rio de Janeiro: Zahar, 2001, p. 117.

${ }^{166}$ ESSLIN, Martin. Uma anatomia do drama. Trad. Barbara Heliodora. Rio de Janeiro: Zahar Editores, 1978 , p. 107.

167 "O prefácio-manifesto pode, enfim, militar a favor de uma causa mais ampla do que a de um gênero literário.” GENETTE, Gérard. Op.Cit., p. 202.
} 
As lúcidas e agudas observações ${ }^{168}$ feitas por Dias denunciam de forma clara e embasada a esterilidade do papel do Conservatório, o qual, sancionado pela legislação, sobre a qual, provavelmente para evitar desafetos e empecilhos, Gonçalves Dias, coloca toda a culpa, desempenhou uma função apenas censória de caráter repressivo, tornandose, dessa forma, um auxiliar da polícia e afastando-se do propósito literário e cultural. Além disso, o dramaturgo sugere como essa associação através da crítica e da provocação de debates e polêmicas poderia contribuir para o desenvolvimento da arte e da formação de gosto.

\begin{abstract}
Quem tem a culpa é a lei; e tanto mais culpada é ela, que, se meia dúzia de mancebos, de seu moto próprio, se reunissem para o mesmo fim, a sua pequena associação seria necessariamente mais vantajosa às letras do que o instituto do Conservatório. Sem autoridade legal, os decretos dessa reunião ou associação, para que fossem de alguma importância, deveriam ser fundados na boa razão, na justiça e na imparcialidade. A sua crítica diária, hebdomadária ou mensal, publicada pela imprensa, chegaria ao conhecimento de todos, e, suscitando polêmica, serviria para iniciar o público nos segredos da arte, para formar-lhe o gosto, quando o não tivesse formado, e avigorarlhe a opinião já criada, quando fosse a boa. Seria enfim uma instituição criadora ao invés de não ser nem conservadora, frutífera ao invés de estéril, e auxiliadora ao invés de ser repressiva. ${ }^{169}$
\end{abstract}

O Prólogo gonçalvino é mais uma prova de que a referida instituição não propiciou o incremento do teatro brasileiro como alvitrava, mas, contrariamente, o inibiu. De forma sutil, o autor aponta para a esterilidade, o conservadorismo e a repressividade, além de sugerir que os pareceres do órgão dramático eram arbitrários e injustos. Tudo isso contribuiria para inibir o desenvolvimento do teatro brasileiro.

168 “O drama é feito para ser representado, e entre nós só podem ser representados os que forem aprovados pela censura competente; de maneira que o nosso Conservatório Dramático da Corte, e um delegado de polícia nas províncias, tem um veto onipotente contra o qual não há recurso, ou eu não o conheço. Quem nos dirá que na primeira folha do malfadado manuscrito não gravaria o Conservatório Dramático o seu veto? O veto é tanto mais fácil de ser exarado, que a lei não exige o porquê, tanto mais fácil que dele não há recurso senão para ele, e ainda tanto mais fácil que ou ele se aplica às produções estrangeiras, e o autor não pode ou não quer advogar a sua causa, ou a nacionais, e estes temem quebrar a sua carreira; temor infundado, bem se vê, pois que o Conservatório é superior a estas ninharias; mas enfim é temor, e contra ele não sei que haja medicina. A culpa quem a tem não é o Conservatório Dramático, folgo de o poder dizer com verdade; o Conservatório tem homens de conhecimentos, de consciência e de engenho, homens que são a flor da nossa literatura e os mestres do nosso teatro. Mal me estaria a mim, autor efêmero e desconhecido, querer levar mão de um só de seus louros, que eu sei de quanto desinteresse carece, de quanta força de vontade, de que impulsão irresistível do gênio ou do fado, quem quer que entre nós se abalança a colhê-los no meio do indiferentismo da nossa gente e do sorriso quase mofador, quase compassivo dos que os não deviam conhecer. Mas digo que esses literatos não poderiam ser úteis ali, porque executam fielmente a lei, que é um regulamento policial ao invés de ser uma medida puramente literária. Digo que até os folhetins que se publicam no Jornal do Comércio sob o título - Semana Lírica - são em tudo de mais efeito e utilidade do que as censuras do Conservatório, mesmo quando a Minerva lhes dava tal ou qual publicidade.” DIAS, Gonçalves. Prólogo a Leonor de Mendonça. In: Op. Cit., p. 910.

${ }^{169}$ Idem, ibidem. 
Inspirado nos princípios do Conservatoire de Paris e do Real Conservatório Dramático de Lisboa, o Conservatório Brasileiro propunha:

\begin{abstract}
(...) incentivar o talento nacional para a arte dramática, corrigir os 'vícios' da dramaturgia brasileira, julgar obras nacionais e estrangeiras que pretendessem ser representadas nos palcos do Brasil, dirigir os trabalhos cênicos e chamá-los aos grandes preceitos da Arte, por meio de uma análise discreta que apontasse os 'defeitos' e indicasse os 'métodos' de os corrigir, publicar semanalmente um jornal que abordasse a arte dramática, noticiando o ocorrido nos teatros da Corte, com reflexões críticas quanto à 'invenção dos dramas e sua execução". ${ }^{170}$
\end{abstract}

No entanto, a atividade do Conservatório limitou-se a julgar as peças que pretendiam ser representadas na corte, autorizando ou não a sua encenação. Vale lembrar que a censura, anteriormente, era exercida pela polícia que, aliás, continuou a desempenhar esse papel concomitantemente com o Conservatório, o que causou embaraços e confusões. Os critérios de avaliação eram a fidelidade à moral oficial, o respeito à religião e aos poderes constituídos, visando o melhoramento da atividade dramática, o refinamento do gosto e dos hábitos do público.

\begin{abstract}
A diferença entre a censura feita por essa instituição e aquela feita pela polícia estava no fato de os censores apontarem os erros e as possíveis correções que deveriam ser feitas para que os textos teatrais se 'adequassem' a seus princípios. Mas essas correções e adequações se caracterizavam como imposições não negociáveis. ${ }^{171}$
\end{abstract}

Os preceitos da associação eram coerentes com o processo de construção de identidade nacional urdido pelo Segundo Império. Instituído nos primeiros anos do reinado de d. Pedro II (1843), assim como o Instituto Histórico e Geográfico Brasileiro (IHGB), o Conservatório Dramático Brasileiro era dirigido por um quadro de literatos que, em acordo com o poder estabelecido, objetivava a afirmação da cultura nacional. A legislação da instituição reverbera o caráter utilitário que é legado à arte dramática, a qual deve garantir a ordem estabelecendo um padrão moral e de costumes que permitiria ao Brasil um caráter civilizado de cunho europeizante. Dessa forma, os julgamentos do Conservatório Dramático Brasileiro observavam sobretudo o conteúdo das peças em

170 SÁ, Carolina Mafra de. Teatro idealizado, teatro possível: uma estratégia educativa em Ouro Preto (1850-1860). Belo Horizonte, 2009, Dissertação de Mestrado em Educação. Universidade Federal de Minas Gerais, p. 68.

${ }^{171}$ Idem, ibidem, p. 69. 
detrimento dos aspectos técnicos ${ }^{172}$. É importante ressaltar que o estreitamento das funções do órgão deve-se também às dificuldades enfrentadas pelo Conservatório que não recebeu do governo imperial apoio ou subsídios suficientes para as despesas primárias. Mesmo com a contribuição de alguns sócios efetivos e correspondentes, a instituição nunca obteve recursos para a publicação de um periódico semanal ou para a criação de uma escola de teatro ${ }^{173}$. Dessa forma, a censura que objetivava a construção de um padrão moral e civilizatório tornou-se a única atividade que justificava a existência da instituição.

Como contraponto a atividade do Conservatório, Gonçalves Dias cita a atuação de Martins Pena como crítico no Jornal do Comércio, os folhetins do comediógrafo relatavam e comentavam peças e óperas analisando-lhes as falhas bem como incentivavam os envolvidos na arte dramática a melhorar o desempenho para que a cena brasileira pudesse desenvolver-se tomando como exemplo o teatro europeu ${ }^{174}$.

\footnotetext{
Pode-se comparar o folhetinista crítico-teatral ao homem que, tendo diante de si uma cesta de frutas, escolhe de preferência para saborear as danificadas e imperfeitas, deixando de lado as sazonadas e sãs. Vai o público ao teatro para gozar o que há lá de bom, e o folhetinista para esmerilhar o que há de mau; agradável passatempo é aquele, desagradável ocupação é esta. ${ }^{175}$
}

Em seu trabalho, Carolina Mafra de Sá destaca que outros empecilhos para a efetividade do trabalho do Conservatório Dramático Brasileiro foram a discordância entre os membros e a ação do presidente Diogo Soares da Silva Bivar que, desrespeitando as regras da instituição, fazia prevalecer a sua opinião nos pareceres sobre as obras examinadas. Durante a presidência de Bivar, a análise conteudística foi priorizada e a imagem do Conservatório plasmou-se como a de um mero auxiliar da

172 SILVA, Luciane Nunes da. O Conservatório Dramático Brasileiro e os ideais de arte, moralidade e civilidade no século XIX. Niterói, 2006, Tese (Literatura Comparada). Universidade Federal Fluminense. 173 "Os sócios efetivos na ocasião de receberem os seus diplomas, concorrerão para a caixa do Conservatório com a quantia de dez mil réis, e anualmente com a prestação de seis mil réis. Estas prestações servirão para ocorrer-se às despesas do expediente e administração, e outrossim para sustentar a publicação de uma folha semanária que trate da Arte Dramática, em todas as suas partes, e na qual se dê notícia dos Teatros da Corte com reflexões críticas, assim quanto à invenção dos dramas, como no que disser respeito à sua execução. Fica porém entendido que a publicação da Folha de que trata este artigo, o qual será distribuída 'gratis' aos sócios, só terá lugar quando haja um número tal destes que o fundo proveniente de suas prestações baste para custear as despesas de impressão. Se em algum tempo houverem sobras, serão estas aplicadas para prêmios a favor dos autores de quaisquer produções dramáticas de invenção nacional" Artigo $10^{\circ}$ da Legislação do Conservatório Dramático Brasileiro apud SILVA, Luciane Nunes da. Op. Cit, p. 28.

174 ARÊAS, Vilma Sant'Anna. Na Tapera de Santa Cruz: uma leitura de Martins Pena. São Paulo: Martins Fontes, 1987, p. 7.

175 PENA, Martins Luiz Carlos. Folhetins. Rio de Janeiro: Ministério de Educação e Cultura: Instituto Nacional do Livro, 1965, p. 363 apud ARÊAS, Vilma Sant'Anna. Op. Cit., p. 59. 
polícia que também exercia a censura e era quem dava o veto ou a liberação às peças ${ }^{176}$. O trecho da carta de Gonçalves Dias, de $1^{\circ}$ de outubro de 1846, ao amigo Alexandre Teófilo de Carvalho Leal reverbera o papel censório e moralista do órgão dramático representado por Diogo Bivar:

\begin{abstract}
A minha Beatriz teve pena de excomunhão máxima - isto é - está interdita de entrar no Santuário das artes - scil[i]cet - no Teatro. O Bivar que fulminou aquela tremenda excomunhão, encarregou-se da oração fúnebre: tem invenção, disposição e estilo, disse ele, mas é imoral! - Não lhe posso querer mal por isto. Deu-me a entender bem que a publicasse, o que foi sempre a minha intenção, e que é agora mais que nunca. ${ }^{177}$
\end{abstract}

Com efeito, incesto e parricídio eram temáticas demasiadamente antagônicas aos princípios defendidos pelo Conservatório Dramático Brasileiro, cuja predileção recaía sobre as produções que não ofendessem o pudor: “As atribuições do Conservatório limitam-se a apontar os pontos descarnados do corpo que a decência manda cobrir: nunca as ofensas feitas às leis do pais, à religião... do Estado; mais nada"178.

Como é sabido, Leonor de Mendonça teve melhor sorte e foi aprovada pelo Conservatório Dramático Brasileiro, mas parece não o ter sido por João Caetano, que, aliás, teria sido criticado por perpetuar temas, autores e estéticas de um repertório clássico e descontextualizado. Como empresário e diretor teatral, ele teria prejudicado a produção nacional e moderna ${ }^{179}$ como a recusa ou as escusas para não representar Leonor de Mendonça provam, pois a postura do ator negou ao belo drama o acesso ao palco: "O João Caetano, elogia ao meu drama, gosta muito dele etc. mas a maldita

${ }^{176}$ É interessante notar que mesmo os membros do Conservatório tinham consciência da inocuidade de seu trabalho como atesta o discurso de Joaquim Manuel de Macedo por ocasião da morte do presidente da instituição, Diogo Soares da Silva Bivar, em 1864: "Dói-nos mas é força dizê-lo: o Conservatório Dramático Brasileiro não pôde fazer pelas letras e pela arte dramática o que por certo estaria na mente e no empenho do seu principal fundador. O trabalho foi estéril, a dedicação perdida, os resultados nulos. Não tinha sido uma instituição prematura; nasceu, porém, e foi deixada incompleta; nunca mostrou ser o que seu título dizia; nunca passou de uma simples auxiliar da censura policial dos teatros, ou antes, das sobras dramáticas... O Conservatório Dramático Brasileiro ressentiu-se, e morreu desse desacerto dos poderes públicos; quiseram que ele vivesse exclusivamente para a censura; para a censura bastava a polícia; a sua vida era inglória, devia morrer" SOUSA, José Galante de. O teatro no Brasil. Tomo I. Rio de Janeiro: Instituto Nacional do Livro, 1960, p. 319 apud SILVA, Luciane Nunes da. Op. Cit., p. 50-51. ${ }^{177}$ DIAS, Gonçalves. Correspondência. In: Op. Cit., p. 1052-1053.

178 Nesse texto de 1859, Machado de Assis deixa-nos entrever que o Conservatório continuou a exercer um trabalho de cunho estritamente policial. Nesse escrito, o autor questiona a necessidade de se recrutar homens de letras para fazer uma atividade que se mostrava inócua. Ele pontua que seria muito mais profícuo para o desenvolvimento do teatro no Brasil se a instituição julgasse os méritos literários das composições. Dessa feita, em conformidade com a posição de Gonçalves Dias no Prólogo a Leonor de Mendonça, Machado requer do Conservatório um papel mais intelectual e crítico, devendo considerar os aspectos estéticos em suas deliberações sobre as peças. ASSIS, Machado. O conservatório Dramático. O Espelho. 25 de dez. de 1859. In: ASSIS, Machado de. Obras Completas de Machado de Assis: Críticas Teatrais. 6. vol., São Paulo: Editora Formar, s/d, p. 205.

${ }^{179}$ SILVA, Luciane Nunes da. Op. Cit, p. 96. 
Companhia Lírica francesa trá-lo tão embeiçado, que ele vai dando mão à sua companhia." ${ }^{180}$ Atores célebres como João Caetano preferiam textos melodramáticos, pois neles as personagens eram apenas esboçadas e cabia ao intérprete complementar e delinear os caracteres ${ }^{181}$. Ainda sobre a recusa de João Caetano, Hessel e Raeders, em sua obra sobre o teatro à época de d. Pedro II, fazem uma interessante inferência, eles relacionam a predileção do ator brasileiro pelas obras de Dumas em detrimento dos dramas hugoanos como hipótese para a aceitação das peças de Macedo e Pena e a rejeição às peças de Alencar e Gonçalves Dias.

\begin{abstract}
Uns e outros, ao elaborarem uma obra destinada ao palco, não deixavam de aspirar a vê-la à luz das ribaltas do Teatro de João Caetano. Nesse ponto uns foram mais felizes que outros. Martins Pena e Joaquim Manuel de Macedo, por exemplo, mereceram-lhe as graças, ao passo que os nordestinos Gonçalves Dias e José de Alencar passaram pelo desgosto de não ter esse gostinho. Terá João Caetano detectado nas peças de ambos algo de natureza semelhante ao que lhe motivou a preferência do teatro de Alexandre Dumas pai sobre o de Vítor Hugo? ${ }^{182}$
\end{abstract}

Por fim, é importante notar a epígrafe do prólogo gonçalvino, retirada da comédia Bristo de Antônio Ferreira: "Contentar a todos ninguém o alcançou, muitos se contentaram com aprazer a muitos. O autor tomará por grande honra satisfazer a poucos. Prof. da Com. de Bristo". A epígrafe, além de retomar noções que Dias já apresentara no prólogo dos Primeiros Cantos, cuja subjetividade, princípio romântico, é transparente (“[...] escrevi-as [poesias] para mim, e não para os outros; contentar-me-ei, se agradarem, e se não... é sempre certo que tive o prazer de as ter composto"), antecipa o nexo precípuo do texto que é o sentido de inovação. Sabendo-se, no entanto, que Antônio Ferreira era um autor clássico, seria no mínimo contraditório apontarmos alguma similitude entre a citação e o subjetivismo romântico. No entanto, adiante, G. Dias volta a citar Antônio Ferreira em nota de rodapé, tomando-o como um exemplo de inovação, pois este utilizara a prosa em suas duas comédias, Cioso e Bristo. É a nota, portanto, que esclarece o verdadeiro sentido da epígrafe e, por extensão, de todo o

\footnotetext{
${ }^{180}$ Dias, Gonçalves. Correspondência. Carta a Alexandre Teófilo de Carvalho Leal de 06 de abril de 1847. In: Op. Cit., p. 1065.

181 “José de Alencar compreendeu-o com muita clareza, dando a razão pela qual João Caetano não poderia interessar-se por papel demasiadamente escrito como o de $O$ Jesuita: 'O papel do grande ator tinha de ser apenas o esboço da estátua que ele, o sublime escultor das paixões, moldaria em cena, ao fogo da inspiração.” PRADO, Décio de Almeida. João Caetano: o ator, o empresário, o repertório. São Paulo: Perspectiva; EDUSP, São Paulo, 1972, p. 117.

182 HESSEL, Lothar; RAEDERS, Georges. O Teatro no Brasil sob Dom Pedro II. Porto Alegre: Ed. da Universidade Federal do Rio Grande do Sul; Instituto Estadual do Livro, 1979, p. 23.
} 
Prólogo, o qual discutirá inovações como o uso concomitante do verso e da prosa, a inclusão da música em cena, a fusão de gêneros e a fatalidade trágica decorrente do contexto histórico-social. 


\section{LEONOR DE MENDONÇA: UM ESTUDO}

Devido ao fato de Leonor de Mendonça basear-se numa crônica, a fortuna crítica tendeu a classificar a peça como drama histórico, embora Dias a tenha designado drama original. Tais classificações, no entanto, não devem inibir a perscrutação da relação da obra com outros gêneros dramáticos e essa é uma das intenções do presente capítulo. $\mathrm{O}$ diálogo intergêneros decorre sobretudo do contexto cultural em que a peça foi produzida, bem como das experiências estéticas do autor. O drama em questão incorpora características relevantes do drama burguês, do melodrama, da tragédia clássica, do drama romântico e histórico conseguindo sustentar sua força dramática até hoje devido a sua riqueza estética. Além disso, a comparação do drama gonçalvino com os preceitos da dramaturgia romântica e com as produções europeias e brasileiras da época permitirão aprofundar a análise da obra.

Primeiramente, discute-se a relação da obra de Dias com os dramas burgueses, principalmente no que se refere à questão da contenção e valorização do sentimento. Nesse sentido, também serão abarcadas as produções góticas, pois elas contêm o gérmen de características presentes em obras românticas, como é o caso de Leonor de Mendonça. Em seguida, discutiremos as aproximações e distanciamentos do drama em questão com o melodrama e o teatro antigo, sobretudo no que tange à noção de trágico. Depois serão apresentadas considerações da relação do drama gonçalvino com as produções de cunho histórico e o drama romântico por meio de exemplos estrangeiros, como Maria Stuart e A noiva de Messina de Schiller, Antony de Dumas, Chatterton de Vigny e Frei Luís de Sousa de Almeida Garret, além de algumas obras dramáticas de Victor Hugo. Por fim, compararemos a obra em questão com produções brasileiras oitocentistas, as tragédias de Gonçalves de Magalhães e dramas de Martins Pena e Luís Antônio Burgain, a fim de destacar como a obra gonçalvina firmou um diálogo muito mais profícuo com a estética romântica do que outros exemplos contemporâneos. 


\subsection{O drama burguês}

Com o enfraquecimento do regime feudal e o desenvolvimento da indústria e do comércio, a burguesia torna-se financeiramente mais representativa que a nobreza, e, portanto, almeja alcançar representatividade política e social ${ }^{183}$. O trabalho, antes depreciado, passa a ser valorizado e necessário para o engrandecimento moral. A cultura do bom gosto migra das mãos da aristocracia para a de jovens especialistas ou produtores de arte e bens culturais ligados à burguesia. ${ }^{184}$ Diante desse quadro, a monarquia absolutista, os privilégios da nobreza, bem como as formas de expressão dessa classe, inclusive a tragédia neoclássica, passam a ser questionados.

No teatro, Denis Diderot defende o desenvolvimento de um gênero intermediário, a comédia séria ${ }^{185}$, que propunha emocionar o público de maneira a fazêlo refletir sobre a natureza humana. Algumas propostas do drama burguês persistirão no teatro romântico, como a mistura de gêneros e adoção de temática contemporânea.

Vale lembrar que, no século XVII, a separação dos gêneros trágico e cômico já fora questionada. Corneille, por exemplo, já criticara a cláusula dos estados, isto é, a regra de que o protagonista trágico deva ser um rei ou nobre, e afirmara que o monarca, personagem típico da tragédia, poderia agir de maneira cômica; enquanto Molière utilizava formas consideradas nobres em suas grandes comédias, como a estrutura em cinco atos e o verso ${ }^{186}$. Aliás, a valorização da sentimentalidade no século seguinte, decorre, também, da interpretação dada a Molière. No século XVIII há empatia por suas personagens cômicas, desvendando-se nelas certa tragicidade ${ }^{187}$. Segundo Hauser, a

\footnotetext{
183 "Gradualmente, a burguesia foi tomando posse de todos os instrumentos de cultura; não só escrevia livros, mas também os lia, não só pintava quadros, mas também os adquiria. No século precedente, ela ainda formava um segmento comparativamente modesto do público leitor e apreciador de arte, mas agora é a classe culta por excelência e converte-se no verdadeiro sustentáculo da cultura. A maioria dos leitores de Voltaire já pertence a essa classe e os de Rousseau quase exclusivamente." HAUSER, Arnold. História social da arte e da literatura. Trad. Álvaro Cabral. São Paulo: Martins Fontes, 1998, p. 506.

184 ELIAS, Norbert. A peregrinação de Watteau à ilha do amor: seguido de seleção de textos sobre Watteau. Rio de Janeiro: Jorge Zahar, 2005, p. 38.

${ }^{185}$ Diderot denominou o novo gênero de 'comédia séria', os seus difamadores, de 'comédia lacrimosa', e os historiadores, de 'drama burguês'. Para o filósofo e dramaturgo francês, o também chamado gênero sério era o "ponto intermediário na escala do sistema dramático, dividido em comédia séria e tragédia doméstica. Excluindo o 'ridículo que faz rir' e o 'perigo que faz fremir', próprios da comédia e das tragédias clássicas, o efeito desse gênero sobre o espectador será o enternecimeno das lágrimas, a doce emoção provocada pelos exemplos edificantes da virtude" MATOS, Franklin de. O Filósofo e o Comediante: ensaios sobre literatura e filosofia na Ilustração. Belo Horizonte: EDUFMG, 2001, p. 19 e 45.

${ }^{186}$ NAUGRETTE, Florence. Op. Cit., p. 22.

${ }^{187}$ SZONDI, Peter. Teoria do drama burguês. Trad. de Luiz Sérgio Repa. São Paulo: Cosac Naify, 2004, p. 121 .
} 
ênfase dada ao sentimentalismo foi uma atitude em favor da autoafirmação dos valores da burguesia, pois o culto ao sentimento se opunha à concepção aristocrática de vida. Com a afirmação da burguesia, a expressão dos sentimentos deixou de ser apenas uma questão de identidade/alteridade para tornar-se um critério de julgamento da arte.

\begin{abstract}
O sentimento converte-se no veículo mais confiável entre o artista e o público, e o meio mais expressivo de interpretação da realidade, conter a expressão do sentimento agora significa abster-se completamente da influência artística, e viver sem sentimento significa ser insensível. ${ }^{188}$
\end{abstract}

Além de valorizar a emoção e a sensibilidade, o público passa a considerar a representação dos vícios, típico da comédia, algo imoral e corruptível. O teatro, por meio de um gênero misto, deveria expor exemplos de virtude em vez de alardear a corrupção do homem e da sociedade. A exposição de personagens exemplares seria mais eficaz na correção dos costumes. De acordo com preceitos iluministas, o homem é naturalmente bom e os desvios dessa essencialidade virtuosa poderiam ser rescindidos.

\footnotetext{
Para o poeta dramático, os deveres dos homens constituem um filão tão rico quanto seus vícios e ridículos. As peças honestas e sérias sempre terão êxito, mas certamente sobretudo entre povos corrompidos que em outra parte. Indo ao teatro poderão safar-se da companhia dos perversos que os cercam; é lá que encontrarão aqueles com quem gostariam de viver; é lá que verão a espécie humana tal qual é, reconciliando-se com ela. ${ }^{189}$
}

Segundo Hauser, o ascetismo da moral burguesa adviria, assim como o individualismo e o emocionalismo, de sua luta de afirmação em relação à aristocracia. Dessa forma, o que estaria em jogo não seria a dilatação das virtudes - simplicidade, honestidade e lealdade - que a burguesia divisava como autorreferência, mas o protesto contra o que ela considerava características aristocráticas: a vaidade, a extravagância e a leviandade, as quais deveriam ser extirpadas da sociedade ${ }^{190}$.

\footnotetext{
Sempre que o hábito ou a novidade tornam incerto meu julgamento - pois um e outro produzem tal efeito -, recorro a uma forma de decisão que muitas vezes me deu bons resultados: é a de captar os objetos pelo pensamento, transportá-los da natureza para a tela e examiná-los a essa distância, onde não estão nem muito longe nem muito perto de mim.

Apliquemos aqui este critério. Tomemos duas comédias, uma no gênero sério, outra no gênero jocoso; montemos, cena por cena, duas galerias de quadros e vejamos onde passearíamos por mais tempo e com mais prazer, onde experimentaríamos sensações mais fortes e agradáveis e para onde seríamos levados a voltar.
}

\footnotetext{
${ }^{188}$ HAUSER, Arnold. Op. Cit., p. 559.

${ }^{189}$ DIDEROT, Denis. Op. Cit., 2005, p. 41.

${ }^{190}$ HAUSER, Arnold. Op. Cit., p. 559.
} 
Insisto, pois: o honesto, o honesto. Ele nos comove de forma mais íntima e doce que aquilo que provoca nosso desprezo e nossas risadas. ${ }^{191}$

Para os teóricos do drama burguês, o maior mal da tragédia neoclássica seria o menosprezo pelos temas da sociedade contemporânea, o que, contrariamente seria o escopo do novo gênero, precursor, nesse sentido, do drama romântico. Inspirado por Diderot, em seu "Ensaio sobre o gênero sério" que prefacia o drama Eugênia de 1767, Beaumarchais defende a fidelidade ao real como meio para suscitar emoções e melhorar a moral do espectador. Para esse autor, o drama sério alcançaria esse objetivo mais satisfatoriamente que a tragédia e a comédia, pois aquela ensinaria apenas o fatalismo e a resignação e esta não suscitaria a reflexão do público, ou seja, a crítica das formas antigas justificaria a mistura dos gêneros. Além disso, na comédia séria, muito mais que na tragédia, cujas personagens estão distantes da realidade do espectador burguês, há uma identificação do público com os caracteres, os quais representam pessoas comuns e são elaborados como um produto de seu meio social.

Franklin de Matos assevera que Diderot combatia o teatro clássico francês e todas as suas convenções arbitrárias preferindo o teatro antigo e Shakespeare. Para o filósofo francês, a artificialidade da tragédia neoclássica impossibilitava a expressão da "natureza humana", cuja essência seria a virtude. Em contrapartida, o gênero intermediário proposto por ele seria capaz de demonstrá-la por meio da imitação das ações mais comuns da vida ${ }^{192}$. Para ele, o entrecho, o desfecho, a linguagem e a representação do teatro neoclássico eram artificiais:

\begin{abstract}
Se o segredo do teatro antigo, numa palavra, é a sua naturalidade, na cena moderna, ao contrário, por toda a parte domina a artificialidade: aqui os desenlaces são 'miraculosos', a ação é sobrecarregada de episódios, e 'ordinariamente tão complicada, que seria um milagre que tantas coisas se tivessem passado em tão pouco tempo'. Nem a tão decantada arte do diálogo dos autores franceses é capaz de compensar esta falta de ilusão do tratamento da intriga, pois as suas personagens não se exprimem de forma natural, mas enfática e espirituosamente, num estilo cheio de floreios. (...) Para completar o quadro, à ênfase dessa 'linguagem singular, cadenciada, rimada', devem-se acrescentar 'o andar afetado dos atores', 'a esquisitice de seus trajes' e 'a extravagância dos seus gestos.' 193
\end{abstract}

${ }^{191}$ DIDEROT, Denis. Op. Cit., 2005, p. 44-45.

192 MATOS, Franklin de. Os Filósofos e o Teatro da Revolução. In: MATOS, Franklin de. Op. Cit., 2001, p. 173 e ss.

${ }^{193}$ Idem, Entre a Enciclopédia e a Comédia. In: Op. Cit., p. 27. 
Na Alemanha, foi Lessing ${ }^{194}$ quem difundiu as novidades propostas por Diderot, as quais foram seguidas pelo grupo do Sturm und Drang, inclusive por Schiller. Pode-se dizer que enquanto o trágico na tragédia antiga mormente resulta do conflito entre o homem e o cosmos, no drama decorre da desordem no âmbito social. Um pessimismo em relação à sociedade caracteriza o movimento stürmer. O indivíduo inevitavelmente se indispõe contra a civilização e esse embate é fatal para ele ${ }^{195}$. Para Duvignaud e Lagoutte, a tragédia contemporânea "transpose sur le plan de la fiction et avec les moyens imaginaires, le conflit entre un désir infini de plénitude et le jeu destructeur de la négativité ou de la répression social.", apreciação que pode ser estendida para o drama romântico. ${ }^{196}$

Intriga e amor ${ }^{197}$ de 1784 foi a contribuição de Schiller para a tragédia burguesa nos moldes dos trabalhos anteriores de Lessing, Miss Sara Sampson de 1755 e Emilia Galotti de 1772. Produção bastante significativa e crítica, a peça schilleriana descreve os desmandos da pequena nobreza contrapondo-os aos anseios burgueses de liberdade, especificamente, a liberdade de $\operatorname{amar}^{198}$. O entrecho do drama resume-se à impossibilidade de casamento entre uma burguesa e um nobre. O presidente Von Walter arranja o casamento de seu filho Ferdinand com a nobre Lady Milford, mas o jovem apaixona-se por Luise, filha de um músico. Para separar os apaixonados, o pai de Ferdinand e seu secretário Wurm prendem os pais de Luise e a chantageiam para que escreva uma carta de amor para outro, o marechal Von Kalb, a fim de provocar o ciúme e o repúdio de Ferdinand. Para proteger os pais, Luise só revela que a carta era falsa antes de morrer envenenada pelo próprio namorado, o qual é tomado pelo desespero diante da falsa traição dela.

\footnotetext{
${ }^{194}$ Em Lessing "a revolta contra a literatura tradicional, agora travada em termos mais violentos, ligava-se a um protesto contra o absolutismo de que o classicismo francês fora expoente. [...] Como a Ilustração em geral, Lessing se empenhava por uma reforma política e social, criticando exacerbadamente os abusos dos príncipes absolutistas (p. ex. na peça Emília Galotti); este 'engagement' político-social caracteriza, sem dúvida, muitas peças dos jovens dramaturgos do movimento [Sturm und Drang].” ROSENFELD, Anatol. Op. Cit., 1991, p. 9.

${ }^{195}$ Idem, Ibidem, p. 9-10.

196 DUVIGNAUD, Jean; LAGOUTTE, Jean. Le théâtre contemporain, culture et contre-culture, Paris: Larousse université, 1974, p. 102 apud BRILHANTE, Maria João. Caminhos da herança clássica até ao teatro francês contemporâneo. Máthesis, Viseu, n. 12, 2003, p. 208.

197 SCHILLER, Friedrich. Intriga e Amor: uma tragédia burguesa em cinco atos. Trad. Mario Luiz Frungillo. Curitiba: EDUFPR, 2005.

198 Vale lembrar que o movimento Sturm und Drang confere ao amor a mais elevada dignidade trágica, tornando-o sublime e um "direito natural e inalienável". AUERBACH, Erich. Mimesis: a representação da realidade na literatura ocidental. 5. ed., São Paulo: Perspectiva, 2004, p. 393.
} 
O drama schilleriano é importante para pensarmos a relação entre o drama burguês e o drama romântico, pois, com o advento do romantismo, a luta por amor simbolizará as aspirações sociais e espirituais:

(...) na medida em que o comovente laço amoroso, totalmente privado pela sua essência, não mais encontrava a oposição de parentes, pais ou tutores malvados, ou obstáculos morais particulares, mas se defrontava com um inimigo público, a antinatural estrutura de classe da sociedade. ${ }^{199}$

Com o drama burguês é revogada a separação entre a personagem cômica (burguesa) e a personagem trágica (nobre), os caracteres deixam de ser universais e passam a ser individualizados e caracterizados por sua condição social e certo psicologismo. Os valores e conflitos burgueses que envolvem a família, o trabalho e a moral puritana são colocados em cena. Uma mudança repentina da fortuna, o temor da desonra, uma paixão que acarreta ruína, desespero e morte são os propulsores da ação e da compaixão.

As principais características do drama burguês, como a recusa das regras neoclássicas de unidade e de bienséance, a noção de genialidade ${ }^{200}$, a mistura dos gêneros, a defesa de um naturalismo em cena ${ }^{201}$ e a instrução da virtude, esboçadas nos escritos de Diderot, Mercier, Beaumarchais e Lessing, serão essenciais para o desenvolvimento do drama romântico e do melodrama. Todos esses gêneros tratarão não só da burguesia, mas de todas as classes sociais em sua relação com o Estado. Além disso, os estratos sociais mais baixos deixam de ser representados de forma cômica ou acessória. Aliás, segundo Diderot, a ação da sociedade e não a paixão dos caracteres é mais importante para o novo gênero, ou seja, no gênero sério pinta-se a influência das condições sociais e familiares sobre o comportamento do sujeito.

Que não são mais, na verdade, os caracteres que é preciso pôr em cena, mas as condições. Até hoje, na comédia, o caráter tem sido o objeto principal e a

\footnotetext{
${ }^{199}$ Idem, ibidem, p. 393.

${ }^{200}$ Segundo Hauser, no Pré-Romantismo somente ao gênio era facultada a liberdade de criação, o não ajustamento às regras. Já no Romantismo, as regras perdem a validade e todo artista tem o direito de criar com liberdade. HAUSER, Arnold. Op. Cit., p. 651.

${ }^{201} \mathrm{O}$ naturalismo sugerido pelos teóricos do drama burguês não se confunde com um mimetismo incondicional, mas de escolhas que visam emocionar o público: "Parce que le sublime, soit en peinture, soit en poésie, soit en éloquence, ne naît pas toujours de l'exacte description des phenomènes, mais de l'emotion que le génie spectateur en aura éprouvée, de l'art avec lequel il me communiquera le frémissement de son âme, des compairisons dont il se servira, du choix de ses expressions, de l'harmonie dont il frappera mon oreille, des idées et des sentiments qu'il saura reveiller en moi. DIDEROT, Denis. Réfutation suivie de l'ouvrage d'Helvétius intitule L'Homme (1773-1774) apud NAUGRETTE, Florence. Op. Cit., p. 44.
} 
condição não passou de acessório; é preciso que, a partir de agora, a condição se torne o objeto principal e o caráter seja apenas o acessório. Era do caráter que se tirava toda a trama. Procuravam-se, em geral, circunstâncias que o ressaltassem e depois elas eram encadeadas. A condição, seus deveres, suas vantagens, suas complicações é que devem servir de base à obra. Parece-me que esse manancial é mais fecundo, mais amplo e mais útil que o dos caracteres. Por menos que o caráter fosse exagerado, um espectador podia dizer a si próprio: não sou eu. Mas ele não tem como ignorar que a situação que está sendo apresentada diante dele seja a sua; ele não pode desconhecer seus deveres. É indispensável que ele aplique a si mesmo o que ouve. ${ }^{202}$

Essa importância dada às condições sociais será perpetuada no drama romântico e no drama histórico, aquele mostrará as implicações da sociedade burguesa materialista e puritana sobre o indivíduo, este apresentará fatos temporalmente distantes para analisar as ações do indivíduo no processo histórico.

Após a Revolução, prevalece a concepção burguesa do casamento, em contraponto ao modelo aristocrático ${ }^{203}$. A escolha desses elementos faz sobressair os aspectos sociais e históricos da sociedade, os quais serão ainda mais evidenciados no drama romântico.

Peter Szondi na obra Teoria do drama burguês analisa o gênero dramático burguês a partir de seu advento no século XVIII através das teorias de George Lillo, Denis Diderot e Gotthold Ephraim Lessing relacionando-as historicamente e indicando os valores burgueses inerentes às proposições e peças dos autores citados. Szondi opõese ao postulado de Lukács sobre o drama burguês caracterizar-se pela encenação da oposição de classes. Para aquele, $O$ mercador de Londres (Lillo), O filho natural (Diderot), O pai de família (Diderot) e Miss Sara Sampson (Lessing) são exemplos que desmentem tal teoria. Para Szondi é a abolição da cláusula dos estados que justifica o novo gênero. Aliás, há peças burguesas em que os protagonistas, ironicamente, são aristocratas. Em O pai de família de Diderot os protagonistas são nobres, embora sejam apresentados como uma família burguesa.

202 DIDEROT, Denis. O filho natural ou as provações da virtude: conversas sobre o filho natural. Trad. e notas Fátima Saadi. Org. J. Guinsburg. São Paulo: Perspectiva, 2008, p. 166.

203 "Deve ser suficiente apontar que o matrimônio aristocrático de corte realmente não tinha como propósito o que, na sociedade burguesa, chamamos de uma 'vida familiar'. Na verdade, quando se realizava um casamento nessa esfera, o que estava em jogo era sobretudo a 'fundação' e o 'prosseguimento' de uma 'casa' que correspondesse à posição do marido, aumentando o máximo possível seu prestígio e suas relações de modo que o casal ganhasse ou pelo menos mantivesse a posição e a reputação como representantes da casa no presente. É nesse contexto que devemos entender a relação entre o senhor e a dama da casa, entre o grand seigneur e sua esposa. O que a sociedade controla, em primeira instância, é o relacionamento dessas duas pessoas como representantes de sua casa. De resto, eles podiam se amar ou não, ser fiéis ou não, sua relação podendo ser tão desprovida de contato pessoal quanto permitisse a obrigação de representar conjuntamente.” ELIAS, Norbert. Op. Cit., 2001, p. 73. 
O que se destaca com toda a clareza nas cenas iniciais de $O$ pai de família de Diderot, -, é a mudança social. Trata-se menos do advento de uma nova camada social do que da mudança na forma de organização da sociedade. Os heróis dos dois dramas burgueses de Diderot não são burgueses. Os de $O$ pai de familia pertenciam à baixa aristocracia; (...) Mas a vida que esses nobres levam é a vida burguesa. ${ }^{204}$

Outro aspecto importante do drama burguês é a mudança do efeito causado no espectador. Enquanto a tragédia visava inspirar o terror por meio da exposição da fragilidade do homem diante do destino e dos deuses, o drama burguês estimula o sentimento de compaixão que advém da aproximação entre o público e as personagens, para que dessa forma a sua versão moralizante da ideia de catarse obtivesse resultado incidindo sobre a maneira de pensar e agir dos espectadores.

\begin{abstract}
Em vez de cantar o heroico, a musa trágica de Lillo lamenta a dor de um homem simples, no qual os espectadores burgueses podem se reconhecer. Porém, visto que o que acontece a esse aprendiz de mercador não é apresentado como o ditado cego do destino, mas é causado por ele mesmo, pelo erro que perpetrou, resulta possivelmente da piedade que se sente por ele a firme decisão de não cometer o mesmo erro ou, se ele já foi cometido, de repará-1o. ${ }^{205}$
\end{abstract}

\title{
3.1.1. O âmbito doméstico, a coerção social e o psicologismo
}

Conforme comentado anteriormente, o gênero proposto por Diderot antecipou o drama na tentativa de sobrepujar o teatro neoclássico e impor o privilégio da estética do efeito sobre o racionalidade das regras. Nesse sentido propõe-se pensar em que medida as inovações temáticas e formais da comédia séria e da tragédia doméstica estão presentes em Leonor de Mendonça que, convencionalmente, é classificado como drama histórico, já que o enredo, como é sabido, foi retirado de uma crônica portuguesa do século XVI incluindo, portanto, figuras históricas na ação.

Para Diderot o teatro serve para disseminar a virtude que a artificialidade da sociedade de corte e das tragédias neoclássicas ajudava a minar ${ }^{206}$. O que quer dizer que

\footnotetext{
${ }^{204}$ SZONDI, Op. Cit., p. 121-122.

${ }^{205}$ Idem, ibidem, p. 52-53.

206 "Eu tenho as minhas ideias, talvez justas, com certeza bizarras, sobre certas ações, que encaro menos como vícios do homem do que como consequência de nossas legislações absurdas, fontes de costumes tão absurdos quanto elas, e de uma depravação que eu chamaria de bom grado artificial." DIDEROT, Denis apud GUINSBURG, J. Denis Diderot: o espírito das "luzes". São Paulo: Ateliê Editorial, 2001, p. 86.
} 
para o filósofo a virtude está ligada à ideia de natureza ${ }^{207}$. Em acordo com esse pensamento de cunho iluminista, o espetáculo teatral deve aproximar a humanidade de sua índole natural, a bondade, tornando-a melhor e fazendo-a 'amar a virtude e odiar o vício'. O gênero sério propõe com a comédia séria, a qual coloca a virtude em risco e a recompensa no final, e com a tragédia doméstica, cujos enredos representam desgraças familiares, reaproximar o espectador de sua natureza reconciliando-se com a humanidade. A força de expressão e a capacidade de iludir desses espetáculos, diferentemente do teatro neoclássico francês criticado por suas regras arbitrárias que o tornavam insípido, advêm da inclusão de cenas cotidianas e de personagens de diferentes classes sociais, bem como da valorização dos sentimentos.

As informações acima servem para refletir sobre haver uma possível aproximação entre Leonor de Mendonça e o gênero denominado tragédia doméstica, já que o enredo do drama em questão trata de um acontecimento trágico relacionado a uma família, apresenta a insatisfação do indivíduo com a existência e expõe um código moral baseado em valores como tolerância, humanidade e amor. Os sentimentos e os direitos individuais são valorizados e o tema da escolha do cônjuge com base na afeição é predominante ${ }^{208}$.

No Prólogo e no drama Leonor de Mendonça, Dias não dialoga com a proposta iluminista de melhorar o homem, colocando-o em contato com a virtude. Contrariamente, o autor enfatiza as contradições das personagens que agem de acordo com o contexto histórico, premidas pela sociedade. Pode-se argumentar que no drama burguês o meio social também é valorizado, mas não como o propulsor da tragédia, pois, em geral, é a virtude ou a falta dela que desencadeia o desenlace. Enquanto a obra dramática de Diderot tem como escopo incutir a virtude nos espectadores apresentando caracteres que agem de acordo com a moral burguesa, para Gonçalves Dias importa apresentar o conflito entre as personagens no que concerne ao papel social de cada um

207 Sobre essa questão em Diderot, Guinsburg esclarece que: “o mito do Bom Selvagem e do paraíso perdido, ou seja, o estado natural, é utilizado não menos como tipo de uma sociedade ou moral primitiva, essencial ou ideal, do que como um contratipo de uma críitica social e ética da ordem vigente." GUINSBURG, J. Ibidem, p. 88.

208“They questioned the rights of the individual versus social prejudices and injustices. Now drama was concerned with the individual and the sentiments of the individual. The right of an individual to choose his own mate in marriage in opposition to conventional standards and marriages de convenance was to be a major and predominant theme in these plays in England, France and Spain. The new concept of morality based on friendship, tolerance, humanity and charity were principles exalted by Rousseau as fundamental to man's happiness." KOSOVE, Joan Lynne Pataky. The 'Comedia Lacrimosa' and Spanish Romantic Drama (1773-1865). London: Tamesis Books, 1977, p. 27. 
num determinado contexto histórico sem determinar soluções ou qualquer lição de moral de cunho maniqueísta. Como foi exposto no capítulo sobre o Prólogo, o final trágico da peça gonçalvina dialoga com o sublime schilleriano e com a proposta de Victor Hugo sobre a arte ter de expressar verdades incisivas. Assim, os enredos retirados da história são preciosos porque demonstram a luta da humanidade pela liberdade moral frente às coações do mundo sensível. A obra gonçalvina versa sobre a questão da luta pela liberdade e não sobre a virtude, seja no que concerne o plano do enredo tendo em vista o mundo ético-político, seja no plano estético.

O objetivo de Dias não se coaduna ao escopo moralizante proposto por Diderot para o gênero sério e nem à estética iluminista de cunho ilusionista que privilegiava o conceito da quarta parede ${ }^{209}$. Assim, as aproximações entre a peça gonçalvina e o drama burguês são pertinentes se considerarmos a primazia deste gênero. No sentido de que inovações como a recusa das regras das três unidades, a inserção de personagens da comédia em enredos sérios e a valorização do efeito sobre o público, propostas por Diderot na França, são disseminadas e retomadas por movimentos pré-românticos e românticos. Questões como a introdução do âmbito doméstico e do psicologismo no gênero sério também são reverberadas no drama, pois refletem aspectos históricosociais compartilhados. No entanto, nos dramas românticos os valores burgueses deixam de ser exaltados e, esteticamente, ressalta-se a ideia da congregação dos contrários, do sublime e do grotesco, da tragédia e da comédia, como a melhor forma de combater a artificialidade do teatro neoclássico.

Com base na análise de Szondi (2004) de $O$ mercador de Londres ${ }^{210}$, nota-se que em Lillo transparece a questão do autocontrole característico da sociedade burguesa. Coagido por suas vontades e pulsões, Barnwell é condenado porque comete erros, ou seja, ele perde o controle de suas ações e transgride as normas sociais. Se compararmos as ações de Barnwell com as da protagonista do drama de Gonçalves Dias, contrariamente, ela contém suas volições e tenta manter com o marido uma relação

\footnotetext{
209 “Assim, quer compondo, quer representando, não penses no espectador, é como se ele não existisse. Imagina no proscênio uma grande parede que te separa da plateia e representa como se a cortina não subisse.” DIDEROT, Denis. Op. Cit., 2005, p. 79.

${ }^{210}$ O Mercador de Londres ou A História de George Barnwell centra-se na personagem-título, um jovem aprendiz que é seduzido pela prostituta Sarah Milwood, a qual o incita a cometer crimes. Primeiramente ele lesa o seu empregador e depois assassina o tio para roubar-lhe. O casal é então condenado e executado. A peça foi encenada em 1731 e distingue-se por focar a ação em elementos da classe trabalhadora e incutir uma lição moral.
} 
pautada pela urbanidade, pela obediência à etiqueta de corte, mas mesmo assim é condenada. Nesse sentido, embora a infração às leis sociais seja um elemento importante na obra gonçalvina, ela não transparece enquanto lição moral como em Lillo: “A resposta ao sofrimento, nessa tradição, é inevitavelmente a redenção, e a resposta ao mal vem como arrependimento e virtude. ${ }^{211}$ " Antes, Leonor é vítima da contenção imposta pela sociedade e não um exemplo de mau comportamento que não deve ser seguido como no caso de Barnwell.

O desfecho do drama burguês reestrutura a unidade (geralmente) familiar que simboliza a coesão nacional. No drama romântico a figura do perturbador social é extirpada, mas continua a provocar no espectador a ideia de que a fissura social permanece ${ }^{212}$. A morte dos “amantes", Leonor e Alcoforado, ao mesmo tempo heróis e perturbadores, restabelece a ordem social, mas denuncia as injustiças sociais.

No drama burguês, a contenção dos sentimentos transmuta o conflito para o interior do sujeito que, resignado, torna-se melancólico ${ }^{213}$. No início do drama brasileiro em questão, a duquesa Leonor tende a resignar-se e interiorizar seus desejos e sentimentos como acontece nos dramas burgueses. Nos diálogos com o duque ela se mostra submissa, e, com Paula ${ }^{214}$, revela-se condescendente com o marido.

A DUQUESA - Pobre homem!

Paula - Pobre! Bem terrível que é ele!

${ }^{211}$ WILLIAMS, Raymond. Tragédia Moderna. Trad. Betina Bischof, São Paulo: Cosac \&Naify, 2002, p, 53.

212 "On voit comment le drame romantique représent une rupture par rapport au drame bourgeois, de Sébastien Mercier à Scribe, don't la structure de base est suivant: la société fonctionne comme système un, niant la division de classes; [...] la thêatralisation mime la restauration de l'unité; le dénouement voit la conversion ou l'expulsion du perturbateur aristocrate ou tyran, indigne de faire partie du corps social (centré autour de la bourgeoisie); la famille unie (microcosme de la nation unie) s'est reconstituée. C'est un mecanisme voisin qui fonctionne dans le melodrama ou dans la comédie bourgeoise. Seule change selon les moments historiques la nature du perturbateur: l'aristocrate, le tyran ou bien le revolté. Dans l'ensemble du drame romantique, la distinction des deux espaces indiques la profondeur de la fracture sociale; ce les héros par une marche inverse, qui est le pertubarteur du corps social, et sa destruction finale redonne au système son unité, mais lasse subsister la fissure [...]" UBERSFELD, Anne. Le roi et le bouffon: étude sur le théâtre de Hugo de 1830 à 1839. Paris: Librairie José Corti, 1974, p. 452.

213 Sentimentalidade é a expressão tabu em que se transforma todo o conflito entre os membros de uma família. O conflito é negado, pois cada um está convencido da bondade do outro. Mas a recusa do conflito significa somente a sua passagem para o íntimo do sujeito. [...] A consequência é sofrimento, melancolia. As duas coisas, a razão e a consequência da renúncia à decisão do conflito, levam àquela plangência que caracteriza o estilo sentimentalista. SZONDI, Peter. Op. Cit., p. 89-90.

214 Vale lembrar que como o confidente, alter ego do herói, representado muitas vezes por um amigo perfeito ou um empregado, é aquele que escuta as confidências mais inconfessáveis, ele é um importante recurso dramático para a exposição da prospecção interior do protagonista colaborando, dessa fora, para a caracterização dessa personagem. PRADO, Décio de Almeida. A personagem do teatro. In: CANDIDO, Antonio et al. A Personagem de Ficção. São Paulo: Perspectiva, 2009, p. 88-89. 
A Duquesa - Terrível por quê? Não sabes tu que o duque tem alma grande e coração generoso?

Paula - Generoso e grande quanto quiserdes; o que todavia não obsta a que eu em sentindo os seus passos me não deseje a cinquenta braças pela terra dentro, ou a cinquenta léguas distante dele.

A DUQUESA - Deveras antes compadecer-te do muito que ele há sofrido! Crês tu que a sua tristeza sombria e inexpugnável cifre-se todas nas rugas que lhes vês sulcar o rosto? Não... mais funda é a sua raiz, tu encontrarás no seu pensamento e nas recordações dolorosíssimas que o esmagam. ${ }^{215}$

No entanto, esse quadro não se sustentará e a civilidade que caracterizava a relação do casal será substituída pela exposição de acusações e mágoas, revelando as questões sociais que estruturam o relacionamento entre as personagens: um casal de nobres cujo casamento foi consumado visando à troca de interesse e à manutenção do status e do poder de sua linhagem.

Depois de haver encontrado o jovem Alcoforado nos aposentos da esposa, o duque pede a Lopo Garcia que ouça a confissão da esposa antes de castigá-la. Leonor jura ao padre que, perante os homens, era inocente. Lopo Garcia tenta em vão dissuadir o duque de sua vingança. Posteriormente, Leonor uma vez mais apresenta argumentos de sua inocência, mas d. Jaime mostra-se inflexível. Inicia-se então uma discussão entre eles em que a urbanidade é substituída por insultos. Em Leonor de Mendonça o sentimentalismo é substituído pelo realismo ao divisar os indivíduos num determinado contexto histórico-social, as relações entre membros da nobreza no século XVI em Portugal, e delinear-lhes os conflitos psicológicos, embora conserve uma linguagem mais próxima dos padrões neoclássicos.

O DUQUE - Escândalo maior, senhora, escândalo maior! Quando mentistes ao sacerdote na vossa última confissão, condenastes a vós mesma; se tãosomente profanásseis vosso leito, o crime ficaria ainda convosco! Fora isso apenas impiedade numa cristã, infâmia numa esposa! Há muito disso. Mas que a esposa se lembrasse dos filhos para encobrir o seu adultério, que o crime se lembrasse da inocência para vestir a sua nudez, que a mãe se lembrasse dos filhos para os industriar no crime... eis o que é horroroso, senhora, eis o que é estupendo e inaudito, eis o crime por que haveis de morrer!...

A DUQUESA - Imprudentemente me prodigalizais impropérios e convícios, Sr. Duque. Fui criada em vossa casa, foi vossa mãe quem me educou. Atentai que parte de quanto me dizeis recai sobre quem se encarregou da minha educação.

${ }^{215}$ DIAS, Gonçalves. Op. Cit., p. 914. 
O DUQUE - Por quê? Conheço almas fáceis que se persuadem que ser virtuosa é ser fingida, e que para ser impune basta ser habilmente criminosa. Outras há que nascem propensas para o crime e com o instinto do vício no coração. Há criaturas assim! ${ }^{216}$

A institucionalização das características do homem 'civilizado' estaria ligada à centralização do poder de coerção física e a institucionalização do condicionamento social que faz com que cada indivíduo seja educado no sentido de desenvolver um severo autocontrole. Para esse processo, as cortes foram essenciais, as quais se iniciaram com as agrupações cortesãs feudais no século XII e se desenvolveram, sobretudo na França, com a sociedade monárquica e absolutista do século XVII ${ }^{217}$. Segundo Elias, o mecanismo de coerção, à medida que as relações de interdependência social se intensificam, torna-se mais abrangente e paradigmático.

No drama gonçalvino, as personagens principais sentem-se infelizes por não poderem concretizar seus anseios. A inibição de suas volições se dá por meio de repressões sociais que são interiorizadas pelas personagens. As regras de sociedade não precisam ser condicionadas por nenhum agente externo, pois ela é desenvolvida no interior do sujeito como uma forma de autocontrole. Leonor se interessa pelo jovem cavaleiro, mas efetivamente não trai o marido e nem mesmo admite estar apaixonada, tentando, dessa forma, comportar-se segundo os padrões estabelecidos para as mulheres casadas. Entretanto, os deslizes que ela comete são suficientes para condená-la, o que evidencia a implacabilidade dos paradigmas de comportamento.

Já Alcoforado não paga apenas por um suposto adultério, mas também por infringir os códigos de hierarquia. D. Jaime também sofre por não poder viver de acordo com a sua vontade e aptidão para a religião. No entanto, o duque é o único caracter que, de fato, consuma suas pulsões ao vingar-se dos "amantes", justamente porque, nesse caso, ele está socialmente justificado, pois as regras em relação ao adultério e a sua posição social o legitimam.

No caso de Leonor de Mendonça, o autocontrole que incide nas personagens tolhendo seus desejos deve ser analisado levando-se em conta a complexidade inerente ao drama, pois ele reverbera aspectos sociais do período de elaboração da obra e os da

${ }^{216}$ DIAS, Gonçalves de. Op. Cit., p.963-964.

217 CHARTIER, Roger. Formação social e economia psíquica: a sociedade de corte no processo civilizador (Prefácio). In: ELIAS, Norbert. Op. Cit., 2001, p. 20. 
perspectiva referencial. Nesse sentido, a coerção social representada na obra ora reverbera a estrutura da nobreza portuguesa do século XVI, ora reflete a da sociedade monárquica brasileira do século XIX, conforme os comentários a seguir tentarão delinear. Com isso, não se pretende afirmar que haja uma dicotomia entre essas duas representações presentes no drama, mas sim que o desenvolvimento do processo de autocontrole inerente ao sistema de domínio social é permanente e incide no teatro.

Sobre o avultamento da imposição de autocontrole, vale lembrar que, no século XVIII, os iluministas creem que civilização é um processo contínuo que deve fundar-se em um padrão moral ${ }^{218}$ e de costumes, na habilidade de relacionar-se socialmente e na consideração pelo ajuizamento alheio sobre o comportamento em sociedade. A burguesia desenvolve esse conceito, e a obrigatoriedade da autocoerção é estendida para as pulsões sexuais. A valorização da moral burguesa e de um padrão de comportamento inibidor das volições exaltou o casamento estável, pois as relações amorosas sólidas e duráveis abrandam as paixões avassaladoras ${ }^{219}$. No plano literário, o tolhimento dos desejos inerente à sociedade transparece de forma díspar, produzindo-se obras que se coadunam com o padrão de comportamento burguês e livros que admitem e valorizam a liberdade de amar.

Ao comentar a diferença entre a imagem do homem e da mulher puritanos por meio da análise do romance Pamela de Richardson ${ }^{220}$, Edmund Leites esclarece que à mulher cabia o papel moralizador enquanto aos homens, o papel dominador. O desenvolvimento de uma inibição de cunho moral é tão severo “que bloqueia até mesmo

\footnotetext{
${ }^{218}$ De forma sumária, com base no ensaio 'Ética iluminista e ética discursiva” de Roauanet, pode-se dizer que as teorias e sistemas morais do século XVIII baseiam-se no cognitivismo, individualismo e universalismo. A Ilustração rejeita os preceitos morais da religião e propõe a razão, a capacidade racional de como agir e julgar, como fundamento da ética. O individualismo da moral iluminista se funda na ideia de que o indivíduo age segundo uma lei interior que independe das prescrições religiosas e sociais sendo ele, portanto, responsável por seus atos. Já o universalismo refere-se à conclusão de que a natureza humana é comum a todos os homens. FREITAG, Barbara. Itinerários de Antígona: a questão da moralidade. 4. ed., Campinas, SP: Papirus, 2005, p. 32-33.

${ }^{219}$ LEITES, Edmund. A consciência puritana e a sexualidade moderna. Trad. Élide Valarini. São Paulo: Brasiliense, 1987, passim.

${ }^{220}$ Hauser assevera que somente a partir da obra de Richardson é possível falarmos de um movimento propriamente romântico, pois o romancista teria sido o primeiro a assentar as principais características do estilo. A fórmula criada pelo romancista foi vasta e duradoura de forma que o sentimentalismo, o psicologismo e o individualismo de suas personagens são perpetuados em outras obras românticas. Mas, a “(...) razão decisiva da influência de Richardson foi ter sido ele o primeiro a fazer do novo homem pequeno burguês, com sua vida privada, vivendo dentro da moldura do lar, absorvido pelas questões familiares, indiferente a aventuras e maravilhas fictícias, o centro de uma obra literária." HAUSER, Arnold. Op. Cit., p. 563.
} 
o reconhecimento de seu próprio desejo sexual." ${ }^{221}$ Inicialmente, segundo Leites ${ }^{222}$, há uma tentativa de integrar sexualidade e racionalidade explicando-se, dessa forma, a importância dada ao casamento de convenção que, dada a sua pertinência no plano social e econômico, deve ser estável. A impossibilidade de equilíbrio entre esses dois polos, a racionabilidade pragmática e as pulsões sexuais, converteu-se, ao longo do século XVIII e XIX, em oposição: a moralidade puritana foi exaltada em detrimento da sensualidade.

$\mathrm{Na}$ literatura, o consórcio regido por regras sociais e econômicas vai de encontro à visão romântica que vê no amor uma metáfora para a capacidade humana de se livrar das coerções impostas pela sociedade. Nesse sentido, o casamento entre d. Jaime e d. Leonor teria sido um mau casamento, um casamento sem amor para atender interesses políticos, causando infelicidade recíproca ${ }^{223}$.

[...] quando as fronteiras entre as castas sociais são cruzadas com frequência cada vez maior e não apenas a nobreza, mas também a burguesia têm de defender uma posição privilegiada na sociedade, começa a excomunhão do desenfreado e impoderado amor-paixão, que ameaça a ordem vigente, dando origem a toda uma literatura que levará, finalmente, à Dama das Camélias e aos nossos filmes de Garbo. ${ }^{224}$

Segundo Hauser ${ }^{225}$, os enredos não muito intricados dos romances de Richardson são apenas um pretexto para analisar a consciência e a emoção das personagens. Aliás, a primazia do autor inglês também se deve à criação de personagens que se caracterizam como criaturas cujos sentimentos e paixões são inconstantes. Ao interiorizar os sentimentos e analisá-los, ele cria uma narrativa "psicologicamente realista" ${ }^{226}$. As heroínas de Richardson são ambíguas, pois mantêm um comportamento exemplar (para a sociedade da época), mas deixam o leitor vislumbrar desejos

${ }^{221}$ LEITES, Edmund. Op. Cit., p. 196.

${ }^{222}$ Idem, Ibidem, p. 214.

${ }^{223}$ Es principio irrecusable, según parece, que uma mujer casada debe estar mal casada, y que no se da mujer que quiera a su marido [...] La mujer casada en la literatura moderna es la victima inocente, aúnque se case a gusto. El marido es um tirano [...] El poeta se pone de parte de la mujer, porque el poeta tiene la alta misión de reformar la sociedad. LARRA apud PRADO, Décio de Almeida. Teatro de Anchieta a Alencar. São Paulo: Perspectiva, 1993, p. 290.

${ }^{224}$ HAUSER, Arnold. Op. Cit., p. 524.

${ }^{225}$ Idem, ibidem, p. 563.

226 VASCONCELOS, Sandra Guardini. Dez lições sobre o romance inglês do século XVIII. São Paulo: Boitempo, 2002, p. 72. 
inconfessados. No drama burguês, o protagonista deixa de se distinguir por sua posição hierárquica para se destacar por sua subjetividade, adensando o psicologismo das peças. A expressão dos sentimentos em algumas passagens de Leonor de Mendonça corrobora para o psicologismo das personagens gonçalvinas, as quais descendem dos novos padrões estéticos que o sentimentalismo richardsoniano ajudou a construir ${ }^{227}$.

\begin{abstract}
A burguesia percebeu imediatamente a importância da nova psicologia e entendeu que suas próprias qualidades mais profundas estavam encontrando expressão na intensidade emocional e no teor introspectivo desses romances. Sabia que uma cultura especificamente burguesa só podia ser construída sobre essa base e, portanto, julgou os romances de Richardson não de acordo com os critérios tradicionais do gosto mas segundo os princípios da ideologia burguesa. Desenvolveu novos padrões de valor estético a partir desses princípios, como a verdade subjetiva, a sensibilidade e a intimidade, e lançou os fundamentos da teoria estética do moderno lirismo. ${ }^{228}$
\end{abstract}

A hesitação de Leonor entre a possibilidade de ser amada e comportar-se de acordo com os ditames da sociedade também torna a personagem psicologicamente mais densa. Ao longo do drama, a duquesa mostra arrependimento quando age de acordo com os seus desejos, como no caso da concessão da fita e da entrevista a Alcoforado. Nos dois exemplos ela assevera ter sido imprudente. Consciente de que poderia se trair agindo contra as regras sociais, ela decide que Alcoforado deve partir, mas tal deliberação não impede que suas imprudências tenham consequências trágicas. Seu conflito é interno e externo ${ }^{229}$, ela combate interiormente a disposição para o adultério, e, exteriormente, luta pela vida numa sociedade que a condena. Antes mesmo de Antônio Alcoforado sair de trás do leito de Leonor comprovando sua presença na câmara da duquesa, o duque de Bragança já havia encontrado o barrete do rapaz com a fita de Leonor nele atada. D. Jaime não poderia perdoar a esposa, pois os objetos denunciadores, a fita e o barrete, e a presença do jovem Alcoforado no quarto da

227 A literatura da experiência e confissão perpetrada por Rousseau também colaborou com o desenvolvimento do subjetivismo, da (auto)observação e (auto)admiração. Nos romances herdeiros da subjetividade rosseauniana os protagonistas sentem a discrepância entre sonho e realidade. Já na Nouvelle Héloïse, a luta do herói não se dá contra um indivíduo, mas contra uma necessidade interna.

${ }^{228}$ HAUSER, Arnold. Op. Cit., p. 564-565.

229 "La societé est extérieure à moi sous forme d'instituitions, dês codes, de corps constitués, mais elle est intérieure à moi sous forme de convictions, d'imperatifs collectifs, d'attitudes imitées, de phrases toutes faites. [...] Le destin, la fatalité peuvent être sentis comme une puissance lontaine dont nous sommes les jouets ou comme une force qui chemine en nous sans paraître, pourtant, venir de nous." GOUHIER, Henri. L'essence du théatre. Paris: Vrin, 1968, p. 41-42. 
duquesa a desoras são indícios que, se não são verdadeiros, são verossímeis o suficiente para condenar os supostos amantes.

O que se apresenta no drama da duquesa de Bragança não são o destino da nobre e as consequências de seu assassinato, mas o conflito e a tragédia de uma mulher mal casada. Herdeiro do drama burguês, nele representa-se um mundo doméstico que, no drama romântico, serve para reverberar o comportamento social em relação à defesa do casamento baseado no afeto, à crítica à coerção imposta às mulheres, bem como ao poder da nobreza que pune injustamente os socialmente impotentes. A utilização de um fato passado para analisar o presente é uma característica do drama histórico, mas em Leonor de Mendonça o fato histórico está subordinado aos conflitos sociais, os quais são retratados também através da mistura dos gêneros como a já mencionada cena na casa de Antônio Alcoforado.

As concepções de amor e casamento presentes no drama são inerentes à sociedade do século XIX, mas refletem também as do século XVI, quando o fato histórico representado ocorreu. Vale lembrar que se trata de um texto literário e, portanto, o amor e o casamento retratados não podem ser confundidos com uma representação do real.

No caso do chamado amor romântico, há, segundo Rougemont, um retorno do mito de amor e morte simbolizado no romance de Tristão e Isolda, reverberado na obra em questão na relação entre Leonor e Antônio Alcoforado. Contrária à racionalidade, a lenda medieval desvela o anseio de sofrer a paixão colocando-se à prova até o limite da morte. Essa interpretação explicaria por que na narrativa de origem celta os protagonistas inusitadamente agem de maneira a fomentar a separação e a dor que a ausência inflige: Depois de viverem juntos na floresta, Tristão e Isolda decidem se separar. Tristão "devolve" Isolda ao rei Marcos e parte em busca de novas aventuras cavaleirescas. Por fim, o cavaleiro decide se casar com outra Isolda, o que efetivamente causa a morte dos amantes ${ }^{230}$.

Tristão e Isolda não se amam; eles o dizem e tudo o confirma. O que amam é o amor, é o próprio fato de amar. E agem como se tivessem compreendido que tudo o que se opõe ao amor o garante e o consagra em seus corações, para exaltá-lo ao infinito no instante do obstáculo absoluto que é a morte. ${ }^{231}$

${ }^{230}$ ROUGEMONT, Denis de. A história do amor no Ocidente. Trad. Paulo Brandi e Ethel Brandi Cachapuz. 2. ed. reform., São Paulo: Ediouro, 2003.

${ }^{231}$ Idem, ibidem, p. 57. (Grifos do autor) 
Como na cortesia medieval, no amor romântico ama-se o Amor em si e não a coisa amada. Esse desejo pela paixão leva ao sofrimento e ao esquecimento do mundo até o próprio aniquilamento. Leonor e o jovem cavaleiro não consumam o desejo que sentem um pelo outro fomentando o amor-paixão, e, para ambos, o destino é a morte. No entanto, enquanto Alcoforado arrisca-se até o limite em nome desse Amor, revivendo a lenda de Tristão, a duquesa, ao final, não aceita ou deseja esse desenlace. Dito de outra maneira, em Leonor de Mendonça o mito de amor e morte estudado por Rougemont se reverbera mais propriamente na figura de Alcoforado, pois Leonor não expõe nenhum desejo de abrir mão de viver para poder se unir ao jovem cavaleiro. Nela o desejo racional de continuar viva se sobrepõe à vontade de experimentar a paixão em seu ápice, subsumindo-se no outro e desfazendo-se do mundo.

No romantismo, o amor é considerado o mais nobre dos sentimentos podendo assumir um cunho metafísico, sendo responsável também pela propulsão da imaginação e, portanto, da criação poética ${ }^{232}$. Vale lembrar que, no século XIX, a valorização da supressão do corpo presente em parte da literatura romântica não está baseada estritamente na cortesia medieval, embora a reverbere, mas também na coerção do processo civilizador da sociedade burguesa.

\begin{abstract}
No processo civilizador, a sexualidade, também, mais transferida para traz da cena da vida social e isolada em um enclave particular, a família nuclear. De maneira idêntica, as relações entre os sexos são segregadas, colocadas atrás de paredes da consciência. Uma aura de embaraço, a manifestação de um medo sociogenético, cerca essa esfera da vida. ${ }^{233}$
\end{abstract}

Desse modo, o enaltecimento do amor na literatura deve-se em parte à estrita vigilância que as relações que envolviam o sentimento de amor e afeto eram subordinadas a fim de dirimir as possibilidades de uniões socialmente censuráveis. Mesmo quando apenas esboçadas, essas transgressões eram severamente punidas por meio de isolamento social, de transferência para postos de trabalho longínquos, da supressão de heranças. Essa demasiada vigilância assinala, por outro lado, a força que as pulsões provocavam. O consenso era de que o amor deveria conjugar afeto e

232 “(...) o senso comum via o amor como uma escada para a liberdade, permitindo aos amantes ultrapassar os obstáculos - diferenças de posição social, de religião ou de lealdades regionais - que as convenções espalhavam em seu caminho. Para o bem ou para o mal, o amor, essa energia primordial, era tido como o solvente universal, a nêmesis triunfante da rigidez social e cultural. Era assim, pelo menos, que o retratavam os poetas, ensaístas e romancistas populares." GAY, Peter. A paixão terna: $A$ experiência burguesa da Rainha Vitória a Freud. Trad. Per Salter, São Paulo: Companhia das Letras, 1990, p. 89.

${ }^{233}$ ELIAS, Norbert. Op. Cit., 2011, p. 173. 
sensualidade ${ }^{234}$. A pulsão sexual deveria se subordinar ao sentimento conformando-se assim ao ideal cristão de permitir o desejo sexual apenas para a concepção dos filhos.

Por outro lado, vale observar com Peter Gay que sem as insinuações de imoralidade, a literatura do século XIX teria sido medíocre. No entanto, a maioria das sugestões eróticas e de desregramentos como promiscuidades, adultério e até mesmo incesto, meticulosamente desenvolvidos durante a narrativa, revelavam-se ilusórios ou irrealizados satisfazendo assim a maior parte do público que sentia prazer com as possibilidades de um perigo aparente. "Era como se as incertezas de um safári a uma selva perigosa e inexplorada fossem antecipadas, e ficasse revelado que na verdade a viagem não passava de um passeio ao jardim zoológico da cidade."235

O casamento, tanto na Idade Moderna ${ }^{236}$ como entre a aristocracia brasileira do Oitocentos, era o resultado de uma negociação e não de uma relação de afeto. No Brasil oitocentista, para as famílias ricas, o casamento era uma forma de ascensão social e de conservação do patrimônio, embora os romances da época apregoassem que a felicidade adviria da união por amor. ${ }^{237}$ As mulheres acumulavam a função de contribuir para a imagem da família visando o seu status social. Para tanto deveriam comportar-se exemplarmente nos salões como anfitriãs e na vida cotidiana como esposas e mães. ${ }^{238}$

No Portugal medievo e moderno, a maioria dos casamentos entre a nobreza consumava acordos e pactos familiares, ou seja, os consórcios eram realizados em prol de conveniências políticas e econômicas. Grande parte dos cônjuges não se conhecia até

${ }^{234}$ 'O amor físico é uma necessidade semelhante à fome', mas o amor propriamente dito, é mais refinado, mais variado, mais violento até que a fome, a qual é a mais premente dos apetites corporais. Aplicar a palavra 'amor' à 'reprodução da espécie', reduzi-lo, em outras palavras, às relações sexuais, é a 'blasfêmia mais odiosa' que a sociedade moderna pode proferir. Afinal, a natureza elevou a espécie humana, com seu 'dom divino do pensamento', acima dos animais, e 'nos tornou capazes de experimentar sensações e sentimentos, necessidades e paixões'. Assim, o amor é 'o encontro da necessidade com o sentimento'. Erótico e afetuoso ao mesmo tempo, é 'a poesia dos sentidos' Trecho baseado na obra Physiologie du mariage de Balzac (1829) In: GAY, Peter. Op. Cit., p. 66.

${ }^{235}$ Idem, ibidem, p. 133-134.

${ }^{236} \mathrm{O}$ consórcio entre d. Jaime e Leonor de Mendonça realizou-se em 1502, no início da Idade Moderna, portanto. D. Jaime tornou-se herdeiro jurado da Casa Real em 1498. Casou então com d. Leonor de Mendonça, filha dos duques de Medina Sidônia, considerada a casa nobiliárquica mais importante do Reino de Espanha por ser a de maior antiguidade.

237 "Como os casamentos sem amor, fundados apenas no interesse econômico, eram vistos como um estímulo ao adultério, pondo em risco dessa maneira a propriedade e a descendência, começou a haver uma mudança de atitude, já no final do século XVII, em direção a uma defesa crescente do casamento baseado no afeto e no companheirismo. $\mathrm{O}$ amor passa a se constituir em um novo ingrediente que deve nortear a escolha do par pelos jovens e não é de surpreender que tantos romances ao longo do século XVIII tematizem esse momento crucial na vida de suas personagens, já que uma escolha equivocada poderia ser uma tragédia sem solução, numa sociedade em que divórcio legal só era facultado para os muito ricos, sendo inacessível para a grande maioria." VASCONCELOS, Sandra Guardini Teixeira. A Formação do Romance Inglês: ensaios teóricos. São Paulo: Aderaldo\& Rothschild: Fapesp, 2007, p. 127. ${ }^{238}$ D'INCAO, Maria Ângela. Mulher e família burguesa. In: DEL PRIORE, Mary. (Org.). História das mulheres no Brasil. 8. ed., São Paulo: Contexto, 2006, p. 234. 
o momento da celebração do consórcio matrimonial. Muitas uniões eram oficializadas antes de os noivos se conhecerem através de uma procuração ${ }^{239}$. O casamento aristocrático não tinha como objetivo a formação de um núcleo restrito ao casal parental e seus filhos, o que estava em causa era a fundação ou a continuidade de uma disnatia que correspondesse à posição do marido a fim de potencializar ou manter o prestígio da casa nobiliárquica do nobre. Esse foi o caso na união entre d. Jaime e d. Leonor de Mendonça.

Nesse sentido, não é o ciúme o sentimento que atormenta o duque, mas o orgulho que advém de sua condição social: ser um homem da alta nobreza. A possibilidade de ser considerado ultrajado pela esposa, ou melhor, de ser visto dessa maneira é que desencadeia a sua ação, levando-o a acreditar que deve defender a sua honra. Talvez não seja apenas para colaborar com o figurino do drama que Gonçalves Dias tenha, além do excerto da Casa Genealógica Portuguesa, anexado o sumário que o próprio duque mandou lavrar para assegurar a justiça de seu feito ${ }^{240}$. Notamos que no sumário, há uma preocupação em descrever uma cena de adultério detalhando como Alcoforado e Leonor foram encontrados na mesma câmara dormindo juntos, ou seja, as aparências devem convencer a todos de que a duquesa e o jovem eram culpados ${ }^{241}$. A nobreza do duque, num significado inerente ao século XIX, herdeiro da Revolução, ou

239 FELDMAN, Sérgio Alberto. Amantes e Bastardos: as relações conjugais e extraconjugais na alta nobreza portuguesa no final do século XIV e início do século XV. 2. ed., Vitória: EDUFES, 2008, p. 68.

240 Historicamente, durante o reinado de d. Dinis de Portugal, várias leis de caráter moral foram promulgadas e muitas delas foram mantidas quase sem alteração até o século XIX. Uma delas asseverava que era direito do marido traído justiçar os adúlteros em flagrante, a não ser que o adúltero fosse de grau nobiliárquico superior. Caso os adúlteros não fossem flagrados, o marido deveria provar o delito. Idem, ibidem, p. 165.

241 'Anno, etc. Aos dois dias do mez de Novembro de 1513, duas horas ante manhã pouco mais ou menos, em Villa-Viçosa, nas casas do Reguengo, onde ora pousa o Sr. Duque de Bragança, foi chamado o bacharel Gaspar Lopes, ouvidor de sua senhoria, e João Álvares Mouro, juiz ordinário na dita Villa. Pelo dito Sr. Duque, etc., foi dito ao dito ouvidor e juiz, perante mim tabelião, que elle tinha morto a Senhora duqueza sua mulher D. Leonor, e assim Antonio Alcoforado, filho de Affonso Pires Alcoforado, moço fidalgo de sua casa, por os achar que dormiam ambos e lhe commeteram adultério; pelo que o dito ouvidor e juiz se forão a uma camara onde a dita senhora sohia a dormir, e ahi jazia morta a dita Senhora duqueza e assim o dito Antonio Alcoforado junto na dita camara, um junto ao outro, o qual foi vista a dita Senhora por o dito ouvidor e juiz, e Gonçalo Lourenço, tabelião, que era presente, e eu Alvaro Pacheco; e tinha uma grande ferida por baixo da barba, degollada, que cortára o pescoço a cerca todo, e outra grande ferida por traz, na cabeça, que lhe cortava a cabeça quase toda, que lhe apareciam os miolos, e junto com a dita ferida tinha outras tres muito grande feridas. E dito Alcoforado tinha o pescoço cortado; e em a cama da dita Senhora estava um barrete, dobrado de volta, preto, que diziam eses que ahi estavam que era do dito Alcoforado, e o ouvidor e juiz mandára fazer este auto, para por elle perguntarem algumas testemunhas sobre o dito caso, e mandaram ao dito Gonçalo Lourenço e a mim tabelião que assignassemos este auto; a qual dita Senhora duqueza com uns perfiles de tafetá amarello, e um sainho de velludo negro, e uma cinta de setim raso alconado; assim o dito Antonio Alcoforado estava vestido; e tinha um gibão de fustão prateado com meias mangas e collar e pontas de velludo roxo, e umas calças vermelhas, e uns borzeguins pretos, e sapatos e um saio preto, e uma cinta de couro preto com uma guarnição de prata.' DIAS, Gonçalves. Op. Cit., p. 969 (Grifos nossos). 
seja, numa acepção burguesa, pode ser questionada nesse sentido, como o faz a própria duquesa antes de morrer:

\begin{abstract}
A DUQUESA - Fizeste iluminar o vosso parque, mandastes armar os vossos homens de armas, alvorotastes todo o palácio; para que, senhor? Eu sou mulher, e vós bem me podeis fazer morrer sem ser à força de escândalo e de vergonha, sem me acabrunhar com todo o peso do vosso poderio. Vindes cercado de uma turba vil e mercenária, a quem basta um só aceno vosso para me cuspir no rosto, porque sou mulher e fraca, enquanto que vós sois homem e temido. É isto, ser nobre? ${ }^{242}$
\end{abstract}

Leonor de Mendonça apela para um conceito de dignidade baseado no princípio de justiça e equidade contrária aos valores seguidos por d. Jaime, o qual, valendo-se de sua força e poder para castigar a esposa, expõe a sua covardia e não grandeza, tendo em vista a defesa da igualdade e da liberdade implícita na obra. Daí fazer sentido a pergunta da duquesa. O comportamento do duque segue a "observância rigorosa das distinções de nível social" da sociedade de corte. A conduta de cada um em relação ao outro, que segue regras conjuntamente determinadas, expressa e constrói a opinião social ${ }^{243}$. Assim, aqueles que ocupam uma posição superior deveriam manter um distanciamento em relação aos que estavam em um patamar inferior, reafirmando assim o prestígio. Essa relação é explicitamente expressa e praticada pelo duque, extremamente zeloso da posição que ele e sua esposa ocupam. Vale a pena notar como d. Jaime ensina à Leonor como ela deve se portar diante do grande favor devido ao subalterno Alcoforado. Vejamos as falas que aclaram essa observação:

O DUQUE - Convém que lhe faleis. A pessoas da nossa hierarquia não está bem dever favores a quem quer que seja; porém, quando tal aconteça, deve-se uma remuneração tal, que ele se não lembre do favor prestado, senão do galardão recebido. Falai-lhe, prometei-lhe quanto vos aprouver, que nós de antemão subscrevemos a tudo quanto lhe prometerdes: antes mais que menos... 244

O DUQUE - (...). A duquesa nossa esposa vos quer agradecer a destreza e coragem com que hoje lhes salvastes a vida. Nós nos retiramos; vinde, porém, ter conosco antes de partirdes para a áfrica, e onde quer que estiverdes, lembrai-vos que tendes um amigo no Duque de Bragança e Guimarães. (estende-lhe a mão, Alcoforado hesita ${ }^{245}$ ) - Tomai-a, Sr. Alcoforado; mais nobre que ela a de el-rei; mais leal nenhuma. ${ }^{246}$

\footnotetext{
${ }^{242}$ Idem, Ibidem, p. 952.

${ }^{243}$ ELIAS, Norbert. Op. Cit., 2001, p. 114-118.

${ }^{244}$ DIAS, Gonçalves. Op. Cit., p. 926.

${ }^{245}$ É interessante notar o duplo sentido que a hesitação de Alcoforado abarca, podendo ser um sinal de receio e respeito ou, contrariamente, uma ação de cunho afrontoso. Para d. Jaime, seguro de seu poderio e da extensão de sua magnanimidade, o titubear do jovem reverbera o seu poderio. O vacilo de Alcoforado
} 
Embora as relações amorosas extraconjugais no século XVI fossem mais ou menos aceitas como naturais, sobretudo no caso dos homens, havia certas normas de comportamento a ser seguidas no que reporta a preservação do prestígio e da imagem ${ }^{247}$. No que concerne a este trabalho, vale ressaltar que a suposta traição de Leonor com um representante de uma classe social mais baixa é uma ofensa à honra do duque ${ }^{248}$, por isso, lembramos que Gonçalves Dias esclarece no Prólogo ser d. Jaime cioso de sua nobreza, e não de seu amor. ${ }^{249}$

\begin{abstract}
Originariamente, contudo, a 'honra' expressava a participação em uma sociedade nobre. Alguém tinha sua honra enquanto fosse considerado um membro segundo a 'opinião' da sociedade e, portanto, para a sua própria consciência individual. [...] Esses homens julgavam segundo um ethos específico da nobreza, cujo centro essencial estava na manutenção de tudo aquilo que servia, tradicionalmente, para o distanciamento com relação às camadas que ocupavam níveis inferiores, confirmando com isso a existência nobre como um valor autêntico. ${ }^{250}$
\end{abstract}

Por outro lado, a atitude do duque pode ser lida como uma reação à infidelidade típica da sociedade do século XIX, na qual todas as relações extraconjugais são condenadas $^{251}$. No entanto, é preciso lembrar que Dias se atém aos fatos narrados pela fonte histórica e que as leis lusitanas sobre o adultério nessa época realmente condenavam a traição com a morte. Ademais, segundo Elias, é apenas durante os séculos XVII e XVIII, nas sociedades de cortes absolutistas, que o poder social da esposa quase se equilibra ao do marido, legitimando, dentro de certos limites, as

reflete a consciência de não ser digno da amizade de um nobre tão poderoso. Para o leitor/espectador, ciente da audácia da personagem, o ato do jovem cavaleiro seria uma afronta em contrapartida ao tratamento que ele recebera do duque no início da cena. As falas prévias de Alcoforado colaboram para essa hipótese.

${ }^{246}$ DIAS, Gonçalves. Op. Cit., p. 929.

${ }^{247}$ FELDMAN, Sérgio Alberto. Op. Cit., p. 131-154.

${ }^{248}$ Curiosamente, quando Elias discorre sobre a honra para a nobreza de corte, ele afirma que, sendo ela desenvolvida em círculos aristocráticos de tradição militar, essa reputação deveria ser defendida pelo uso de armas quando a ofensa provinha de um elemento do mesmo estrato social e com desprezo ou com uma surra pelos criados se os detratores fossem de um nível inferior. D. Jaime não mata Alcoforado, mas manda que um negro o mate com um manchil, ou seja, com uma mera faca de cozinha, demonstrando mais uma vez a distância hierárquica entre ele e o jovem fidalgo.

249 Prado chama atenção para essa característica do teatro gonçalvino: no campo social e moral, suas peças são regidas pelas leis de cavalaria, as quais são apresentadas de maneira idealizada segundo a índole romântica. Assim, Beatriz só não perdoa ao pai ter sido humilhada na frente do amado Marcio. Lucrécia se vinga do aviltante tapa que recebeu do marido. Em Patkull, Namry adverte Paikel sobre a importância da palavra empenhada e permanece fiel ao compromisso selado com o noivo. PRADO, Décio de Almeida. Op. Cit., 1996, p. 90-104.

${ }^{250}$ ELIAS, Norbert, Op. Cit., 2001, p. 112.

${ }^{251}$ Idem, Op. Cit., 2011, p. 178. 
relações extraconjugais das mulheres ${ }^{252}$. Assim, a ação do duque na peça não é estranha à época do fato ocorrido, o início da era moderna em Portugal, pois, nesse período, a mulher não tem o mesmo poder social que o marido como também acontece no século XIX.

De acordo com Rosenfeld, no teatro, também se apreende a subjetividade das personagens por meio de suas ações e falas, e o leitor/espectador interage complementado as entrelinhas. Em Leonor de Mendonça, a protagonista tem medo de revelar os seus desejos para as pessoas com quem convive, para o público, e para si mesma. Diferentemente das produções burguesas do século XVIII em que prevalecia um sentimentalismo exacerbado que visava estimular apenas as emoções do público, em Dias, embora o foco também recaia sobre o interior das personagens, a construção é sutil e o espectador deve interpretar as ações da protagonista. Tal procedimento contribui para revelar os liames em que a mulher dessa sociedade regida pelo despotismo patriarcal estava envolvida, liames que a impedem de se expressar, de se defender e de se salvar. As interdições impostas à mulher não precisavam ser explicitadas porque já estavam interiorizadas. A propósito, a participação do espectador na construção das personagens é uma característica essencial para fazer da peça gonçalvina um bom drama, distinto de outras produções brasileiras da época que optavam pelo pragmático modelo melodramático com o intuito de fazer chorar para educar.

\footnotetext{
A forma dramática de expressão deixa o espectador livre para decidir por si mesmo a respeito do subtexto escondido por trás do texto ostensivo - em outras palavras, ela o coloca na mesma situação em que se encontra o personagem a quem são dirigidas aquelas palavras. E por isso mesmo permite que o espectador experimente diretamente a emoção da personagem, em vez de ter que aceitar uma simples descrição dele. Além do mais, essa necessidade de os espectadores decidirem por si mesmos como interpretar a ação acresce ao suspense com que a plateia acompanhará a história. ${ }^{253}$
}

${ }^{252}$ Idem, ibidem, p. 176.
${ }^{253}$ ESSLIN, Martin. Op. Cit., p. 20. 


\subsection{O melodrama}

O melodrama pode ser entendido como uma forma que condensa o patético da tragédia e o desfecho venturoso da comédia. Por meio da representação de situações extremas perpetradas num esquema dramático extremamente codificado, a sensibilidade do público é exacerbada e os valores morais são propagados: os virtuosos são geralmente recompensados e salvos pela Providência. O melodrama, assim como o teatro histórico, popularizou o abandono das unidades, a representação da violência e a estética do espetacular. Em relação à temática, adota principalmente os dramas de família como o drama burguês ou, em acordo com a tragédia e o drama histórico, contextualiza esse mesmo tópico historicamente. As qualidades mobilizadas nesses enredos incluem a abnegação, o gosto do dever, a aptidão para o sofrimento, a generosidade, o devotamento, a humanidade, o otimismo, e confiança na Providência ${ }^{254}$. No entanto, a separação entre questões morais e problemas sociais confere ao gênero um sentido conformista e maniqueísta, o qual, aliás, aconselha a conservação da hierarquia social e prima pela reabilitação da família e da pátria ${ }^{255}$. O mal, encarnado por um vilão, é facilmente extirpado pela sociedade. Por outro lado, o melodrama, em suas origens, foi um gesto de denúncia contra o que a burguesia considerava a moral decadente da aristocracia ${ }^{256}$.

Thomasseau ${ }^{257}$ destaca como propulsores do advento da estética melodramática a lenta transformação do teatro ao longo do século XVIII, e a formação de um público mais popular e sensível às conturbações e violências vividas no período da Revolução Francesa.

Outro aspecto histórico-social considerado intrínseco ao espetáculo melodramático é o desenvolvimento das cidades. As novas concepções de espaço e de tempo geradas pela estrutura das grandes cidades afetaram a percepção humana que foi hiperestimulada. Dessa maneira, a exploração do sentimentalismo, do mistério, do inusitado, de cenas visualmente apelativas no espetáculo melodramático não seria decorrente apenas do prazer pelo mórbido ou do anseio de transgressão, mas uma consequência da mudança da percepção na modernidade.

254 THOMASSEAU, Jean-Marie. O Melodrama. Trad. e notas Claudia Braga e Jacqueline Penjon. São Paulo: Perspectiva, 2012, p. 48.

${ }^{255}$ Idem, ibidem, p. 48-49.

${ }^{256}$ XAVIER, Ismail. Melodrama, ou a sedução da moral negociada. Novos Estudos CEBRAP, n. 57, julho 2000, p. 85-86

257 THOMASSEAU, Jean-Marie. Op. Cit., p. 13. 
Valorizando a mise en scène e o talento dos atores, o melodrama privilegia os aspectos dramáticos em detrimento da linguagem literária. Essa fórmula rendeu inúmeros sucessos e infiltrou-se em outros gêneros congêneres. No drama histórico e no drama romântico, por exemplo, verifica-se a importância dada ao pitoresco pelo primeiro e à utilização dos coups de thèatre por ambos. Para Thomasseau ${ }^{258}$, a aversão ou o preconceito em relação ao gênero deve-se à sua associação, desde o surgimento, com o teatro popular. Tende-se também a julgar o gênero apenas do ponto de vista literário sem, contudo, levar em conta as suas qualidades teatrais.

Huppes condensa a importância do gênero definindo-o como "uma espécie de denominador comum do estilo teatral romântico." ${ }^{259}$ Com base em sua teoria de distinção entre o trágico e o melodramático, $\mathrm{Smith}^{260}$ considera que o sucesso do melodrama deve-se ao modo como os conflitos e crises são encarados na vida real, ou seja, o homem tende a encarar os problemas de uma forma maniqueísta: a sua integridade e bondade são constantemente ameaçadas por alguma fonte maligna que deve ser extirpada a fim de se alcançar a felicidade. Enfrentar as adversidades compreendendo a relatividade das responsabilidades é mais constrangedor e complicado, por isso a preferência pela visão de mundo melodramática.

Em artigo em que examina as razões da permanência do melodrama como gênero hegemônico desde o início do século XIX, Ismail Xavier ${ }^{261}$ assevera que o homem necessita de uma matriz sólida da experiência, mas vive, em contrapartida, em um mundo extremamente instável. Essa instabilidade gerada pela nova ordem capitalista e secular teria no melodrama uma compensação, no plano do imaginário, para os alicerces morais, políticos, econômicos e até mesmo estéticos da sociedade estamental que passaram a ser questionados a partir do final do século XVII e abdicados após a

\footnotetext{
258 "Enquanto as salas oficiais se esvaziavam e a multidão se espremia nas bilheterias do Ambigu e da Porte de Saint Martin, os críticos, pouco perspicazes em sua maior parte, tiveram uma reação de defesa e desprezo por aquele gênero misto que transtornava tantos hábitos estéticos e no qual eles viam pouca originalidade." Idem, ibidem, p. 12.

259 "O teatro de estilo romântico costuma ser associado com o melodrama e o drama histórico. A singularidade temática de cada espécie justifica indicar a dupla alternativa. Grosso modo, observa-se que o melodrama dá preferência a enredos sentimentais, enquanto o drama histórico vai buscar inspiração em vultos resgatados à realidade do passado e ambas as vias, ainda que de forma independente, encontram grandes autores e bastante aceitação. De outro lado a aproximação se impõe, quando observamos que as peças de fundo histórico mobilizam recursos comumente associados ao melodrama. Como estes, elas valorizam a ação, destacam o embate entre o vício e a virtude e exploram as sugestões do cenário tendo em mira o impacto sobre a plateia. Tal coincidência sugere a linha de raciocínio que será adotada aqui. Ou seja, o melodrama aparecerá como uma espécie de denominador comum do estilo teatral romântico." HUPPES, Ivete. Melodrama: o gênero e sua permanência. Cotia, SP: Ateliê Editorial, 2000, p. 9-10.

${ }^{260}$ SMITH, James L. Melodrama. London: Methuen Young Books, 1973, p. 10.

${ }^{261}$ XAVIER, Ismail. Op. Cit., p. 85.
} 
Revolução Francesa. Peter Brooks define o melodrama como uma tentativa de ressacralizar o mundo a partir de outros referentes éticos que não a Igreja, a Monarquia ou a tragédia.

\begin{abstract}
The Revolution can be seen as the convulsive last act in a process of desacralization that was set in motion at the Renaissance, passed through the momentary compromise of Christian humanism, and gathered momentum during the Enlightenment - a process in which the explanatory and cohesive force of sacred with lost its Power, and its political and social representations lost their legitimacy. In the course of this process, tragedy, which depends on the communal partaking of the social body - as in the mass - became impossible. The crucial moment of passage could no doubt be located somewhere in the seventeenth century. ${ }^{262}$
\end{abstract}

Essa ideia de ressacralização associar-se-ia à missão educadora que o melodrama incorpora, pois assume um papel de propagador da moralidade. Considerando o novo público humilde e inculto, Pixerécourt ${ }^{263}$ desejava instilar-lhe princípios de moralidade e de política, por isso acreditava que o gênero deveria ser, ao mesmo tempo, moralmente rigoroso e amplamente influenciador.

Em um artigo de 1852, François Ponsard tenta diferenciar o drama (e a tragédia) do melodrama, já que muitas vezes essa distinção era difícil de entrever. Ele assevera que para considerar uma peça drama ou tragédia, é preciso que o enredo esteja subordinado à representação das personagens, ao desenvolvimento das paixões e à recriação do espírito e das maneiras de uma época. Já o melodrama se caracterizaria pelas aventuras e reviravoltas inesperadas, embora saibamos que esses recursos foram utilizados pelos autores dos dramas históricos e românticos ${ }^{264}$.

Já Robert Bechtold Heilman, em sua obra Tragedy and Melodrama ${ }^{265}$ de 1968, assevera que o que difere o homem trágico do melodramático é a cisão, pois nos melodramas a personagem é íntegra e não se divide entre a vontade e o dever: "He greets every situation with an unwavering single impulse which absorbs his whole

\footnotetext{
262 BROOKS, Peter. The Melodramatic Imagination: Balzac, Henry James, Melodrama, and the Mode of Excess. Nova York: Columbia University Press,1995, p. 15-16 apud BRAGANÇA, Maurício de. Melodrama: notas sobre a tradição/tradução de uma linguagem revisitada. Eco-Pós, v. 10, n. 2, julh-dez 2007, p. 33.

${ }^{263} \mathrm{O}$ francês René Charles Guilbert de Pixérécourt é considerado o mais prolífico autor de melodramas do século XIX. Suas peças alcançaram grande êxito devido aos enredos maniqueístas cheios de reviravoltas e final feliz. $\mathrm{O}$ apelo à cor local e a utilização de cenários mais realistas também contribuíram para a popularidade de seus dramas, tais como Coelina e L'homme à trois visages.

${ }^{264}$ CARLSON, Marvin. Teorias do teatro: estudo histórico-crítico, dos gregos à atualidade. Trad. Gilson César Cardoso de Souza. São Paulo: Fundação Editora da UNESP, 1997, p. 206.

${ }^{265} \mathrm{O}$ comentário sobre a obra de Heilman é feito por SMITH, James L. Op. Cit., p. 7-8.
} 
personality"266. Nos melodramas, o protagonista luta apenas contra pressões externas que, nos enredos, são representadas por vilões, grupos sociais, ideias adversas, incidentes e acasos, pelo destino ou por uma deidade maligna. Nesse sentido, para o autor, mesmo entre as tragédias clássicas pode haver aquelas que compreendam um cunho melodramático. É interessante notar que a definição de trágico em Heilman assemelha-se à schilleriana, já que para ambos o embate interior é essencial à tragicidade ${ }^{267}$. Além disso, tal acepção vai ao encontro de uma das questões essenciais do romantismo que é o sentimento de dilaceramento causado pelo advento da modernidade e que se expressará na arte de forma bastante incisiva.

Outra distinção entre o melodrama e a tragédia bastante pertinente apontada por Smith ${ }^{268}$ reverbera o sentido maniqueísta do primeiro em relação à relatividade do segundo. Nos entrechos melodramáticos há apenas duas possibilidades, a vitória ou a derrota; nos entrechos trágicos pode-se perder ganhando ou ganhar perdendo. $\mathrm{O}$ exemplo de tragicidade schilleriano em Maria Stuart pode esclarecer essa contradição, pois embora Maria seja condenada, moralmente vence sua opositora, Elizabeth. Dito de outra forma, Elizabeth é grandiosa porque conquista o sucesso; Maria é moralmente superior, sublime, por meio da infelicidade.

O que parece ser bastante contraditório na estrutura do melodrama é que para fazer a apologia da moral burguesa, o mal é representado não apenas como uma simples ação, mas como ação prazerosa. E o público, por sua vez, se compraz na contemplação desse teatro do mal. Um dos temas em que se misturam a indignação moral e o voyeurismo seria o da jovem perseguida, cujos sofrimentos seriam "um pretexto para situações de sensualismo obscuro." 269

Há complementaridade entre o vício e a virtude, o sádico só pode se comprazer em contraposição à moral assim como a pureza é valorizada quando supera a impudicícia. O tema muito em voga nos romances góticos vai ser desdobrado na

\footnotetext{
${ }^{266}$ Idem, ibidem, p. 7.

${ }^{267}$ Ao estudar o trágico Lima conclui: "Contudo, parece haver um elemento comum a quase todas estas tentativas empreendidas pelos pensadores do trágico sobre este princípio filosófico. Uma dimensão dialética, contraditória e conflituosa parece permear as definições dadas por diversos pensadores, tais como Schelling, Hegel, Goethe, Schopenhauer, Nietzche, entre outros. Entendido ora como choque de vontades, ora como oposição entre o universal e o particular, entre a liberdade e a necessidade, entre o absoluto e o singular, o trágico parece compor-se de processos dialéticos e contraditórios nas mais diferentes visões." LIMA, Danielle Dayse Marques. Jane Eyre: drama e tragédia no romance de Charlote Brontë. 2008. 211 f., Dissertação (Mestrado em Letras), Universidade Federal da Paraíba, João Pessoa, 2008, p. 103-104.

${ }^{268}$ SMITH, James L. Op. Cit., p. 10.

${ }^{269}$ PRAZ, Mario. A carne, a morte e o diabo na literatura romântica. Trad. Philadelpho Menezes. Campinas, SP: UNICAMP, 1996, p. 103.
} 
literatura e teatro românticos. Um exemplo significativo em Gonçalves Dias é Beatriz Cenci, encarcerada, perseguida e violentada pelo próprio pai. Na peça, o incesto, que contém o mesmo princípio do prazer da transgressão, outro tópico caro aos românticos, é o crime mais hediondo perpetrado pelo malévolo Francisco Cenci. As exacerbações dos desejos e sentimentos são entendidas como contraposição à exortação da interiorização do autocontrole característica da sociedade burguesa ${ }^{270}$. Para Thomasseau, a temática da perseguição no melodrama reflete uma visão religiosa do mundo, pois propaga a compensatória vitória do bem sobre o mal, diferentemente do vezo dado no drama.

A relação entre o melodrama e o drama passou a ser bastante debatida a partir de 1830, principalmente com a voga do drama romântico. De qualquer forma, a afinidade entre os gêneros nunca deixou de ser observada e as diferenças são por vezes deveras sutis; de maneira que mesmo Victor Hugo, o qual sempre tentara diferenciar-se dos autores populares, foi constantemente comparado a Pixérecourt por seus detratores, principalmente quando abdicou do verso em suas produções teatrais ${ }^{271}$.

A partir da queda do Império na França, com a mudança das mentalidades e o enfraquecimento dos valores tradicionais, os temas dos dramas românticos começam a permear os melodramas: os vilões passam a sobreviver à justiça e os heróis tornam-se vítimas da fatalidade. $\mathrm{O}$ amor infeliz, o adultério e a revolta social são incorporados como elementos presentes para sensibilizar o público. Thomasseau ${ }^{272}$ esclarece que a semelhança entre os dois gêneros deve-se ao fato de dramas e melodramas serem escritos pelos mesmos autores, representados pelos mesmos atores e encenados nos mesmos teatros. Além disso, a estrutura do melodrama continuava ser a base sobre a qual se incluíam temáticas novas e os efeitos da cor local. O ritmo, a encenação, e a composição das personagens, elaboradas seguindo o padrão maniqueísta, atestam a preocupação com a coerência interna em detrimento de um viés realista.

A poética explosiva e confusa do melodrama romântico, não sendo tão estritamente codificada como a do melodrama clássico, torna difíceis as

\footnotetext{
270 "A tendência do processo civilizador a tornar mais íntimas todas as funções corporais, a encerrá-las em enclaves particulares, a colocá-las 'atrás de portas fechadas', produz diversas consequências. Uma das mais importantes, já observadas com várias outras formas de impulsos, notamos com especial clareza no desenvolvimento de limitações civilizadoras à sexualidade. É a peculiar divisão dentro do homem, que se acentua na mesma medida em que aspectos da vida humana que podem ser exibidos na vida social são separados dos que não podem, e que devem permanecer 'privados' ou 'secretos'." ELIAS, Norbert. Op. Cit., 2011, p. 181.

${ }^{271}$ CARLSON, Marvin. Op. Cit., p. 205-206.

272 THOMASSEAU, Jean-Marie. Op., Cit., p. 65-67.
} 
classificações rigorosas. São tão somente os critérios ditos 'literários' que permitem distinguir entre drama e melodrama, mas de um ponto de vista estritamente teatral é indubitável que os dramas de Hugo e Dumas têm alguma ligação com a estética de Dennery, de Ducange ou de AnicetBourgeois. ${ }^{273}$

Se levarmos em conta todos os componentes histórico-sociais, culturais e estéticos vinculados ao desenvolvimento do melodrama, pode-se compreender a dificuldade em diferenciá-lo das outras expressões dramáticas coetâneas. O ilusionismo sensacionalista dos espetáculos melodramáticos decorre de uma ambiência transgressora e de afirmação de novos paradigmas históricos, sociais e estéticos pós-Revolução Francesa, o que também explicaria o seu transbordamento tanto em relação à forma como ao conteúdo. Independentemente de seu caráter popular e maniqueísta, o melodrama, assim como o drama burguês, histórico e romântico, reverbera o anseio de uma nova forma de arte dramática que corresponda às necessidades espirituais e estéticas num mundo caracterizado pela cisão e mudanças.

Segundo Faria, no Brasil, o gosto pelo melodrama de cunho sentimental foi assimilado mais rapidamente devido ao repertório das companhias teatrais portuguesas que desembarcaram por aqui e trouxeram a tendência francesa. Essas companhias optavam por peças que teriam aceitação mais imediata. O estudioso acrescenta que essas corporações acabaram por influenciar a consolidação de valores estéticos e de padrões para a arte dramática, como a forma de representar, a composição do espetáculo e dos cenários etc ${ }^{274}$.

\subsubsection{Leonor de Mendonça e a recusa da estética do melodrama}

Ao tratar do adultério como uma possibilidade não consumada sob o ponto de vista sério e como um problema social, como fizera Vigny em Chatterton, Leonor de Mendonça distancia-se do paradigma melodramático, já que inicialmente nesse gênero o amor adúltero era mostrado como uma conduta condenável275. Pixérécourt, célebre

\footnotetext{
${ }^{273}$ Idem, ibidem, p. 94.

274 FARIA, João Roberto (Dir.). História do Teatro Brasileiro: das origens ao teatro profissional da primeira metade do século XX. Vol. I, São Paulo: Perspectiva: Edições SESCSP, 2012, p. 75-76.

275 “[...] nos dramas modernos não se encontram senão crimes monstruosos que revoltam a moral e o pudor. Sempre e em toda parte o adultério, o estupro, o incesto, o parricídio, a prostituição, os vícios mais aberrantes, mais sórdidos, uns mais repugnantes do que os outros. Qual é o resultado? Que as mães de família desertaram de espetáculos aos quais as moças não podem mais comparecer sem escândalo e sem perigo.” PIXÉRÉCOURT, Charles Guilbert apud HUPPES, Ivete. Op. Cit., p. 126
} 
autor de melodramas, critica as temáticas do drama romântico, pois as considerava imorais, ou seja, contrárias ao teor edificante das composições melodramáticas. Nos primeiros autores melodramáticos o amor é colocado aquém dos sentimentos de honra, devotamento patriótico, do amor filial e maternal:

\begin{abstract}
O menos trabalhado dos temas nos primórdios do gênero é o amor. Na ética das primeiras obras do gênero, o amor paixão atua contra a razão e o bom senso, sendo vivido, sobretudo, pelos vilões. (...) Apenas após o advento da estética romântica, os melodramas (...) começarão a se aproximar do tema. ${ }^{276}$
\end{abstract}

Os melodramas primavam pela simplicidade a fim de diminuir qualquer dificuldade de compreensão ${ }^{277}$. Prado afirma que nesse gênero dramático "a retórica elegante cai para segundo plano"278, o que não acontece na obra gonçalvina em que a eloquência é, ao mesmo tempo, refinada, clara e contundente, como atestam os diálogos entre o duque e a duquesa, a duquesa e o Capelão, a duquesa e o jovem Alcoforado. Nesses diálogos é possível entrever inclusive um forte apelo persuasivo que agrega complexidade às personagens.

É interessante notar como Leonor se esforça para convencer Lopo Garcia a intervir por ela. Ela persuade o padre utilizando-se dos três elementos estruturantes do discurso argumentativo: o ethos, o pathos e o logos. A duquesa constrói uma imagem positiva de si mesma, apresenta argumentos com apelo emocional (principalmente quando narra a sua vida triste e solitária) e de cunho lógico ao longo da cena, fazendo uso frequente de perguntas retóricas para conduzir o seu interlocutor a aderir ao seu discurso. Note-se como no trecho a seguir ela constrói seu argumento enfatizando a sua prudência. No entanto, os leitores/espectadores sabem que ela já afirmara ter sido, contrariamente, imprudente ao aceitar a entrevista com o jovem ${ }^{279}$. Leonor, portanto, tem consciência de que é preciso compor as palavras a fim de convencer Lopo Garcia a

\footnotetext{
${ }^{276}$ BRAGA, Cláudia. Melodrama: aspectos gerais do gênero matriz da telenovela. Intercom - Sociedade Brasileira de Estudos Interdisciplinares da Comunicação. Anais. XXVIII Congresso Brasileiro de Ciências da Comunicação. Rio de Janeiro. UERJ. 5 a 9 de setembro de 2005, p. 4-5.

277 "A linguagem do melodrama, avessa a ambiguidades e torneios de estilo, reúne as condições indispensáveis para agradar plateias desabituadas de sutilezas. Além do mais, a peça costuma a prédefinir a moral das personagens como forma de indicar a intepretação pretendida e o faz com uma clareza inequívoca. Todos esses são traços que evidentemente reduzem o esforço demandado ao espectador, facilitando a aproximação.” Idem, ibidem, p. 14.

278 PRADO, Décio de Almeida. O advento do Romantismo. In: FARIA, João Roberto (Dir.). Op. Cit., 2012 , p. 78.

279 “A DUQUESA, (só, sentando-se) - Alcoforado tem alma de fogo; porém, é respeitoso e comedido! Pobre moço!... quis dizer-me adeus sem que nos vissem, e partirá feliz com a ideia de que por ele me interesso. Podia eu fazer menos em favor de quem tão generosamente me salvou a vida?... Não... Mas talvez fui imprudente.” DIAS, Gonçalves. Op. Cit., p. 948.
} 
ajudá-la. Essa cena contribui para a construção de uma personagem complexa que, diferentemente das heroínas melodramáticas, não deixa de agir diante do perigo iminente e tenta se livrar da morte persuadindo o padre e também o marido de que é inocente.

\begin{abstract}
A DUQUESA - Ele ia partir para África, mais por força das minhas instâncias do que por vontade sua. Cheio de funestos pressentimentos, que ainda mal se realizaram, ele se lançou a meus pés pedindo-me que o escutasse. O senhor duque nos podia surpreender, algum pajem nos podia escutar, e ele estaria perdido; fui prudente. Pediu-me uma entrevista para esta noite, que ele devia partir ao amanhecer. Eu conhecia a sua nobreza e honradez; concedi-lha. Dizei: fiz mal em ser prudente para não ser uma ingrata? 280
\end{abstract}

Outra característica que diferencia o drama de Dias dos melodramas coetâneos é a abdicação da estrutura maniqueísta, não há culpados em sua peça. Leonor e d. Jaime têm defeitos que, diante das circunstâncias histórico-sociais, entram em choque e o mais fraco sucumbe. Além disso, em L.M. não há mudanças bruscas nos sentimentos das personagens para consequentemente provocar diferentes emoções no público. Segundo Huppes:

\footnotetext{
Em termos estruturais, o melodrama é uma composição muito simples. Bipolar, estabelece contrastes em nível horizontal e vertical. Horizontalmente, opões personagens representativas de valores opostos: vício e virtude. No plano vertical, alterna momentos de extrema desolação e desespero, com outros de serenidade ou de euforia, fazendo a mudança com espantosa velocidade.
}

O melodrama depende da surpresa, o público espera que a peça se estruture através de vários sobressaltos e na oposição entre as personagens, as quais representam o vício ou a virtude. Em Gonçalves Dias, o elemento principal não é o inesperado, contrariamente, a trama deixa-nos entrever a tragédia iminente. As premonições de Alcoforado e de d. Jaime são exemplos da antecipação do desfecho, opção estética que abdica dos efeitos cênicos surpreendentes e prefere a tensão crescente e sóbria, mas eficaz:

O DUQUE (entrando desalinhado e com os cabelos em desordem) - O javali esteve a despedaçá-la... o venábulo roçou-lhe o rosto... e eu vejo ainda o cadafalso de meu pai!... Crime ou fatalidade, um deles me está iminente; mas qual? Isto não é superstição, é um presságio, uma intuição do futuro. Vejo o relâmpago, o raio não tardará a cair... mas sobre quem?... Por quê?... Não o

\footnotetext{
${ }^{280}$ DIAS, Gonçalves. Op. Cit., p. 962.
} 
sei, mas inevitável!... Oh! Venha embora o azar maldito, que não será pior que esta ansiedade!...281

O exemplo acima é o mais explícito da peça, há outros menos evidentes como o da primeira cena na qual Paula já anuncia a tempestade vindoura dizendo que Alcoforado deveria acender velas para se guardar dos trovões em vez de gastá-las com defuntos ruins. A propósito, os presságios fazem com que a ação se desenvolva, pois os interpretando, o herói toma decisões. No entanto, o cunho velado desses signos é sempre dúbio e abre a possibilidade para outras interpretações que poderão fazer o protagonista salvar-se ou sucumbir.

Em sua obra sobre o melodrama, Huppes aponta elementos melodramáticos em Leonor de Mendonça: a noção de amor como uma experiência única e arrebatadora inerente à figura do jovem Alcoforado e o psicologismo de d. Jaime, cujas justificações para seu comportamento são baseadas no passado que, aos olhos dele, foi marcado pelo sofrimento e injustiça.

\footnotetext{
Examinar as manifestações e as consequências de amor e ódio, do modo como elas se materializam em ações, parece suficiente à dramaturgia da época. Se explicações são necessárias, elas serão buscadas em comportamentos do passado que envolveram ações injustas ou afetos renegados. O Duque de Bragança, em Leonor de Mendonça, é presa de um ímpeto de destruição que provém da violência que a família sofreu quando ele era menino. O rico Senhor não se interroga a respeito, parece-lhe bem simplesmente seguir os impulsos pessoais. ${ }^{282}$
}

A primeira observação feita pela estudiosa na citação acima só pode ser compreendida pela chave que ela propõe: ser o melodrama um denominador comum ${ }^{283}$, já que a exacerbação do amor como um sentimento superior é um tema inerente ao romantismo sendo também incorporado aos melodramas. Em relação ao psicologismo do duque, podemos contrapor a posição de Huppes, pois, com efeito, d. Jaime reflete sobre sua condição:

\footnotetext{
${ }^{281}$ Idem, ibidem, p. 944.

${ }^{282}$ HUPPES, Ivete. Op. Cit., 2000, p. 130.

283 Em Huppes o melodrama é considerado como uma espécie de denominador comum do teatro romântico, pois suas características são comuns aos outros gêneros coetâneos como o drama histórico e o drama romântico.
} 
- O DUQUE - Sim, compadecei-vos, porque eu sou mais infeliz que mau. Apenas me levantei do berço, que ao invés de meu pai vi um cadafalso por cima da minha cabeça; apenas no exílio, fomos envenenados, eu e meu irmão; ele morreu e eu continuei a arrastar a minha vida sobre a terra. Despojado violentamente de quanto há no mundo de mais precioso e caro, continuadamente contrariado nas minhas inclinações as mais íntimas, as mais santas, ainda hoje! Hoje, que sou homem, duque, poderoso e repeitado, como dizem, sofro de ter nascido nobre ao invés de ter nascido vilão, de ser senhor, ao invés de ser vassalo, de ser livre ao invés de ser escravo! ${ }^{284}$

Além disso, de acordo com G. Dias, o duque age em conformidade com as circunstâncias e defeitos, que o fazem orgulhoso, cioso e desconfiado, e não apenas por conta de seu passado. As desgraças de sua infância são apenas parte do que devemos conhecer para compreender a configuração dessa personagem. A posição social de $d$. Jaime é imprescindível para entender as suas ações.

Décio de Almeida Prado ${ }^{285}$ assevera que nos melodramas o mal geralmente se concretiza em um sujeito que é inerentemente mau, cujas ações perversas são decorrentes de sua deficiência moral, não de imperativos sociais ou psíquicos. Ademais, o bem supera o mal no final do conflito para que o espectador sinta-se aliviado e convencido de que a justiça sempre persevera. No drama gonçalvino, o duque age de forma cruel incentivado pelo poder e o código de honra que socialmente o legitimam e pelos problemas psíquicos que o excitam ao crime.

Prado também observa que o drama histórico era pessimista em relação à natureza humana e à organização social, e o melodrama era, contrariamente, otimista. Dessa forma, aquele revestia-se de fatalidade ou ceticismo enquanto este fundava-se na providência de Deus ${ }^{286}$.

A construção das personagens e o conflito entre elas na peça de Gonçalves Dias vão de encontro às características do melodrama que se pauta pela descrição das relações humanas de maneira simplificada. A observação de Décio de Almeida Prado sobre o gênero ilustra essa oposição, pois:

O mal, para ele [o melodrama], não decorre de causas sociais, não possui raízes psicológicas complexas, não nasce da incompreensão, da neurose, do desencontro de opiniões ou de personalidades. Tem sempre forma concreta, personifica-se num indivíduo propositadamente mau: o tirano ou vilão. ${ }^{287}$

\footnotetext{
${ }^{284}$ DIAS, Gonçalves. Op. Cit., p. 927.

${ }^{285}$ PRADO, Décio de Almeida. Op. Cit., 1972, p. 126-7.

${ }^{286}$ Idem. Op. Cit., 1996, p. 57-58.

${ }^{287}$ Idem. Op. Cit, 1972, p. 87. Grifos nossos.
} 
Enfim, não há, no drama gonçalvino, uma oposição maniqueísta entre bons e maus como nos coetâneos melodramas em voga: o duque é cioso, a duquesa, imprudente. Os defeitos de cada um, conjugados com a fatalidade "que dimana toda dos nossos hábitos de civilização", alicerçam o drama para que o efeito do embate final seja grandioso. Segundo Dias, a poesia brotaria do choque das personagens e o drama, por sua vez, do choque das paixões e, com efeito, a oposição entre as personagens, que envolve também as diferenças sociais, são a essência da obra. A propósito, alguns teóricos definem o teatro como a arte do conflito, já que os caracteres só são totalmente determinados a partir do confronto, daí resulta a importância do antagonista e das personagens de contraste 288 .

\begin{abstract}
De fato, o desenho todo do enredo está contido nas três individualidades envolvidas no drama. De um lado, o marido, infeliz desde a infância (como tantos na dramaturgia gonçalvina), não perdoando à mulher o ter-se casado com ele. Do outro, um jovem imaturo, impulsivo, ávido de amor, mas já o vinculando à ideia de morte. No meio, comprimida, a esposa, sensível à paixão que despertou. ${ }^{289}$
\end{abstract}

Vale lembrar que para Hegel o material histórico deve se adequar aos princípios da poesia, elaborando-se a unidade de ação de maneira verossímil e de forma a imputarlhe um conteúdo de cunho universal. O material histórico serve para instigar uma ideia que esse evento intrinsecamente contém e que é mormente expresso por um embate nas inter-relações humanas.

Ela [a poesia] pode ainda ir mais adiante a esse respeito se ela não faz do
Conteúdo e do significado do acontecimento histórico efetivo o seu conteúdo
principal, mas sim algum pensamento fundamental em maior ou menor grau
aparentado com ele, em geral uma colisão humana, e usa fatos e caracteres
históricos, o local etc. mais apenas como uma vestimenta
individualizadora.

Em peças gonçalvinas anteriores a Leonor de Mendonça, os princípios do melodrama são mais evidentes. Huppes ${ }^{291}$ observa que os dramas históricos também valorizavam a ação, o efeito moral e o cenário impactante como os melodramas. Em Beatriz Cenci, por exemplo, Dias explora o artifício da elaboração de um cenário marcante no baile de máscaras, festa que é um subterfúgio de Francisco Cenci para

\footnotetext{
${ }^{288}$ Idem. Op. Cit., 2009, p. 92.

${ }^{289}$ Idem. Op. Cit, 1996, p.114-115.

${ }^{290}$ HEGEL, G.W.F. Cursos de Estética: Poesia. Tradução: Marco Aurélio Werle, Oliver Tolle. São Paulo: Editora da Universidade de São Paulo, 2004, p. 43-44.

${ }^{291}$ HUPPES, Ivete. Op. Cit., 2000, p. 10.
} 
aviltar Beatriz. A didascália da cena VI aponta para a preocupação com o efeito que o cenário e a cena como um todo devem causar: "A cena pomposamente decorada; no meio arcos de flores, no fundo passeiam ou dançam donas e cavaleiros, ricamente vestidos. A música toca brandamente e vai enfraquecendo-se pouco a pouco até parar." 292

Outras concessões melodramáticas presentes no teatro gonçalvino são as coincidências, como o fato de Berta e Namry terem sido seduzidas pelo mesmo homem, Paikel (Patkull) ${ }^{293}$; Boabdil, desconhecendo o amor de Zoraima pelo amigo AbenHamet, confia a ele a missão de descobrir quem é o amante de sua esposa. Além disso, em Boabdil há o clichê da dupla identidade Ibrahim - Aben Hamet. O pai de Zoraima havia negado a mão da filha a Ibrahim. Este, desenganado e em busca da morte, decide guerrear contra os cristãos. Ileso, ele retorna a Granada e muda seu nome para a AbenHamet. Outro elemento tipificado é o enclausuramento de Beatriz em um pequeno aposento pelo próprio pai ${ }^{294}$.

Outrossim, os apartes e as confidências utilizados como expedientes de esclarecimento do enredo, recurso típico do melodrama, não são empregados por Gonçalves Dias. Em L.M, essas falas contribuem para a configuração das personagens, expondo, por exemplo, os pensamentos velados de Leonor:

\begin{abstract}
Há casos em que [os apartes] contribuem para completar o retrato das personagens principais, aquelas a quem é reservado espaço para revelações e de quem o interesse da história demanda decifrar o ânimo oculto. Quando falam sozinhas ou para um interlocutor - o confidente, ou o público, no caso do aparte - expressam motivos íntimos que não poderiam aparecer de outra maneira, a não ser desencadeando prejuízos muito graves. ${ }^{295}$
\end{abstract}

Huppes comenta que as confidências de Leonor à camareira Paula são essenciais para delinear o caráter do duque e exprimir os sentimentos da duquesa em relação ao marido. Shakespeare, por exemplo, utilizava-se desse subterfúgio sem torná-lo superficial ${ }^{296}$. O mesmo poder-se-ia dizer das personagens de Gonçalves Dias na peça

\footnotetext{
292 DIAS, Gonçalves. Beatriz Cenci. In: Op. Cit., p. 866.

${ }^{293}$ De acordo com Hessel e Raeders: "Gonçalves Dias dramaturgo de primeiras águas, utiliza em Patkull os processos usuais do melodrama e, além disso, desajeitadamente: lances imprevistos, repetições, tiradas longas demais, e mesmo um lirismo que soa falso como, por exemplo, na segunda cena do primeiro ato: 'Patkul (como extasiado): - Sinto por ti o que se não diz na linguagem dos homens, no cantar dos bardos, uma coisa que na Terra não em nome, e que os anjos nos céus, entre o coro dos astros, talvez modulem nas suas liras de ouro, quando à Virgem-mãe levantam incensos de louvores". Hessel e Raeders, p. 96-97.

${ }^{294}$ CORREIA, Marlene de Castro. Op. Cit.

${ }^{295}$ HUPPES, Ivete. Op. Cit., p. 74.

${ }^{296}$ ESSLIN, Martin. Op. Cit., p, 44.
} 
em questão: Leonor de Mendonça, ao retratar o marido acaba por pintar a si mesma e a relação entre os dois. A piedade e a subserviência da duquesa e o suspense quanto aos seus verdadeiros sentimentos em relação ao jovem Alcoforado estão implícitos na caracterização e no comentário que ela faz sobre o marido.

\footnotetext{
A DUQUESA - Deveras antes compadecer-te do muito que ele [o Duque] há sofrido! Crês tu que a tristeza sombria e inexpugnável cifre-se todas nas rugas que lhes vês sulcar o rosto? Não... mais funda é a sua raiz, tu encontrarás no seu pensamento e nas recordações dolorosíssimas que o esmagam.

(...)

A DUQUESA - Cala-te (mais baixo) - Eu mesma, Paula, eu mesma, quando adivinho, não me é preciso ver, quando adivinho que meu marido me encara fixamente, sinto o sangue arder-me nas faces e perturba-me toda como se fosse criminosa; e todavia não tenho um pensamento, nem sequer um pensamento de que me deva acusar.
}

A propósito, os solilóquios são a chave para inferirmos que há uma inclinação da duquesa em relação ao jovem Alcoforado. Afeição que ela não ousa transformar em adultério, ou melhor, não se atreve a nem mesmo admiti-la: “A DUQUESA - (...) Não gosto de ouvir falar nele, e não posso pensar em outra coisa. Por quê? (torna-se pensativa)"297. Dessa forma, cabe ao leitor/espectador tentar definir quais são os sentimentos de Leonor em relação a Alcoforado. Gonçalves Dias evita a transparência melodramática.

\begin{abstract}
Quanto à forma teatral, o melodrama preocupava-se primordialmente em guiar o espectador através do labirinto do enredo, não o deixando errar em suas interpretações, informando-o a todo momento de maneira clara e inequívoca. Cada personagem, valendo-se do monólogo e do aparte, técnicas indispensáveis ao gênero, diz não apenas o que está sentindo e pensando em seu íntimo, mas, igualmente, com muita frequência, o que pretende fazer a seguir. Nada permanece nas entrelinhas, não há intenções sub-reptícias deixadas a cargo do talento do autor ou da perspicácia do público. O texto engloba o subtexto, dispensando exegeses, exprimindo literalmente a totalidade dos efeitos desejados pelo autor. ${ }^{298}$
\end{abstract}

Para melhor compreendermos a elaboração das personagens em Leonor de Mendonça, é interessante revermos o estudo de Rosenfeld ${ }^{299}$ que trata sobre a personagem literária. Ele esclarece que diferentemente das pessoas reais, as quais permanecem indeterminadas devido à impossibilidade de conhecê-las inteiramente, as figuras fictícias adquirem um contorno definido e convincente por meio da organização

\footnotetext{
${ }^{297}$ DIAS, Gonçalves. Op. Cit., p. 917

${ }^{298}$ PRADO, Décio de Almeida. Op. Cit., 1972, p. 88.

${ }^{299}$ ROSENFELD, Anatol. In: CANDIDO, Antonioet al. Op. Cit., 2009, p. 34-35.
} 
textual. A seleção e a concentração de alguns aspectos escolhidos dentre a enorme gama dispersa na realidade, bem como exploração dessas feições em situações decisivas e significativas contribuem para esse efeito de completude e concretude das personagens. Dito de outra maneira, a projeção dessas figuras se dá por meio da escolha de características e da organização de orações de forma intencional. Além disso, há autores que têm a capacidade de simular a opacidade das pessoas reais em suas criações ao guiar o leitor/espectador através da seleção das características e da descrição de comportamento e do psiquismo de suas figuras criando a ilusão de incompletude. No caso do teatro, essas feições são construídas por meio do que a personagem manifesta sobre si mesma e do que os outros caracteres falam sobre ela, além da observação de suas ações.

Em Leonor de Mendonça, Gonçalves Dias selecionou para os seus protagonistas uma gama não muito ampla de predicados, mas suficientes para que apresentem certa complexidade $^{300}$. A camareira Paula, por exemplo, além de ser a confidente de sua senhora e, portanto, servir como ponte para adentrarmos na interioridade da duquesa, faz uma série de comentários sobre o duque e o jovem Alcoforado contribuindo para o delineamento de todos os protagonistas. Aliás, as primeiras caracterizações dessas figuras, que serão acentuadas durante todo o drama, devem-se à empregada. As primeiras impressões emitidas por Paula descrevem: a santidade, a bondade e a beleza de Leonor; a fraqueza, a juventude e o desvario de Alcoforado; e o pavor que os olhos negros e sombrios do terrível duque infundem (a violência do nobre também é demonstrada por meio da narração dos exercícios com o cavalo que ela descreve). Essas características citada pela camareira são reforçadas por outras personagens, como em outros trechos em que d. Jaime e o mancebo também se referem à bondade e a beleza de Leonor. Esses atributos são definitivos, mas a eles outros são agregados. No caso da duquesa, outras feições são importantes como a sua imprudência e subserviência, aspectos respectivamente enfatizados por ela e pelo duque. A propósito, o autor foi bastante feliz ao delinear Leonor, pois o seu silêncio e inércia corroboram para definir a sua condição de submissão ${ }^{301}$. Ela não age para conseguir o que deseja, como no caso de querer voltar à corte, mas aceita regressar após a sugestão do marido. Da mesma maneira ela é condescendente com o encontro noturno proposto por Alcoforado.

\footnotetext{
300 Ao comentar a "Canção do Exílio", Antonio Candido chama a atenção para a capacidade de Gonçalves Dias de, com parco uso de adjetivos, escolher expressões simples que, ao mesmo tempo, são justas e precisas. CANDIDO, Antonio. Op. Cit., p. 71.

${ }^{301}$ No final do drama, no entanto, Leonor rompe o silêncio culpando o duque e tenta se salvar.
} 
Leonor, na verdade, deseja regressar à corte e se encontrar com o mancebo, mas não é ela quem toma tais decisões. Como observou Prado, para o dramaturgo: "O essencial é encontrar os episódios significativos, os incidentes característicos, que fixem objetivamente a psicologia da personagem." ${ }^{\prime 302}$

302 PRADO, Décio de Almeida. Op. Cit., 2009, p. 92. 


\subsection{Breves considerações sobre aspectos da tragédia antiga e neoclássica em Leonor de Mendonça}

Em sua História Social da Arte e da Literatura, Hauser afirma que, desde a Renascença, o homem já adquirira consciência de sua individualidade, mas é somente a partir do século XVIII que o individualismo se torna uma forma de protesto contra a "despersonalização" decorrente do processo de civilização. Nesse contexto, o drama é concebido como expressão da alienação do sujeito contra as amarras sociais, e não mais como a antítese pessoal e concreta entre os diferentes personagens de uma peça ${ }^{303}$. Nesse sentido, foram muitas as mudanças na concepção de tragédia movidas pelos valores liberais, como o individualismo e a liberdade, e a necessidade de reformar a sociedade.

Em sua interpretação da tragédia, diferentemente da leitura neoclássica ${ }^{304}$, os românticos suprimem a questão da culpabilidade, o herói não se caracteriza pelo erro, mas pela grandeza revelada ao optarem pela liberdade. Já os heróis de Ésquilo cometem uma falta porque estão submetidos a uma maldição, a um destino inalterável. $\mathrm{Na}$ tragédia grega a concepção de sofrimento inocente e de uma fatalidade injusta jamais acontece se levarmos em conta a ideia da culpa herdada dos ancestrais e assumida pelo protagonista $^{305}$. Na ação trágica antiga, o herói sempre gera o desencadeamento de forças que o estimulam a ultrapassar a justa medida, desequilibrando a si mesmo e a comunidade a qual ele se vincula. A personagem da tragédia sempre expõe a instabilidade da existência humana dando ao teatro antigo um cunho universalizante.

$\mathrm{O}$ conflito do herói da tragédia romântica advém de questões prosaicas. $\mathrm{O}$ protagonista não se sobressai por ser valorizado socialmente. Ele é vitorioso na derrota e sobrepuja moralmente a sua ruína, ou seja, despreza o plano sensível através da liberdade do espírito atingindo a sublimidade.

O drama romântico de Gonçalves Dias expressa o conflito do sujeito premido pela sociedade, a qual suprime a sua liberdade. Leonor, Alcoforado, e até mesmo d. Jaime não podem agir de acordo com sua subjetividade, pois são as normas sociais que

\footnotetext{
${ }^{303}$ HAUSER, Arnold. Op. Cit., p. 557.

304 “(...) na perspectiva cristã, que é a do classicismo francês, são as próprias paixões, e não apenas seu excesso, que são consideradas más. Traduzindo pathos por passion, Corneille está transformando as emoções, pensadas por Aristóteles sem significação moral, em sentimentos irracionais que encarnam no amor profano e cegam quando não são dominados. Pensado como paixão amorosa, o pathos aristotélico torna-se em Corneille desregramento, uma paixão irracional perigosa ou imoral na medida em que ofusca a razão.” MACHADO, Roberto. Op. Cit., p. 33.

${ }^{305}$ Hauser, Arnold. Op. Cit., p. 94.
} 
delineiam o destino dessas personagens. A essa perspectiva da tragicidade, Gonçalves Dias chamou de "fatalidade cá da terra". Essa frustração proveniente do desejo de liberdade que é negada só pode ser resolvida através da morte, seja de si mesmo, ou de outrem. Basta lembrar a ânsia de d. Jaime por sangue: "DUQUE (só) - Eu estava sufocado! (corre a um armário, tira algumas armas que arroja sobre a mesa) - Sangue!... Sangue!... Sangue! (cai)"306.

No entanto, a ideia de conflito entre personagens como estrutura dramática permeia o Prólogo, assim, poderia haver aí resquícios de características da tragédia aristotélica na obra. No entanto, é preciso atentar que ao falar sobre esse embate, Dias assinala que as personagens entram em conflito por conta de seus defeitos, que são de natureza diferente. Essa observação vai de encontro aos preceitos da tragédia grega em cujas personagens não seriam destacados os defeitos, mas apenas a falha cometida pelo protagonista. Ademais, contrariamente à tragédia grega e neoclássica, o conflito em L.M. é oriundo de uma questão social, a qual Gonçalves Dias caracteriza como luta entre fracos e fortes esclarecendo que a fraqueza de Leonor advém da "eterna sujeição das mulheres, o eterno domínio dos homens". Além da desigualdade entre gêneros, a peça pontua a diferença social que separa os duques de Bragança do jovem Alcoforado.

Em Leonor de Mendonça, como na tragédia clássica e neoclássica, o enredo é desenvolvido a partir do ponto culminante, ou melhor, in media res, diferentemente do drama romântico em que a ação pode iniciar pelo nascimento do protagonista ${ }^{307}$ e da tragédia shakespeariana, cujas cenas são independentes entre si. Em sua obra sobre a tragédia, Luna esclarece que ao começar a ação num ponto estratégico, o sentido trágico da ação é acentuado, pois as causas que irão gerar a fatalidade já não podem ser alteradas provocando a sensação da "terrível imutabilidade da ordem das coisas passadas" ${ }^{308}$. No caso do drama histórico, a escolha desse momento específico pressupõe um viés ideológico, pois a partir desse ponto são percebidas as relações causais, ou seja, a seleção dos fatos implica uma forma de interpretação da história. A organização dos eventos estabelecendo relações de causa e efeito, aliás, pode provocar

\footnotetext{
306 DIAS, Gonçalves. Op. Cit., p. 947.

${ }^{307}$ Nos melodramas morais cujos enredos retratavam a escalada da degradação de um homem é comum a exposição de vários anos da vida da personagem, rompendo, assim, com a unidade de tempo clássica. PRADO, Décio de Almeida. Op. Cit., 1996, p. 78.

${ }^{308}$ LUNA, Sandra. Arqueologia da ação trágica: o legado grego. João Pessoa: Idéia, 2005, p. 242 apud SOUSA, Harlon Homem de Lacerda. Tradição e Traição no Drama Histórico: Calabar em revista, no teatro de Chico Buarque. 215 f. 2009. Dissertação (Mestrado em Letras), Universidade Federal da Paraíba, João Pessoa, 2009, p. 68.
} 
no espectador/leitor uma reflexão sobre esses determinantes e sobre qual a melhor forma de se posicionar sobre eles:

\begin{abstract}
Reside aqui um primeiro elemento que terá influência direta do posicionamento ideológico incluso no drama histórico. Aquele ponto importante e sua resolução, como a própria expressão deixa perceber, fixará o ponto de vista pretendido e executado, ou seja, as relações percebidas na História, transformadas em relações causais, manifestam uma forma de interpretação de eventos que pode revelar uma atribuição de importância direcionada ideologicamente. A ação é construída sob um ponto de vista seletivo (ou excludente) que reduz os vários acontecimentos a uma relação de causa e efeito, estabelecendo vínculos lógicos capazes de provocar a reflexão das motivações do espectador/leitor sobre as suas escolhas políticas, ideológicas etc. ${ }^{309}$
\end{abstract}

Premida, ao mesmo tempo, pela sociedade e pelos conflitos internos, Leonor de Mendonça condensa aspectos do trágico clássico e moderno, pois na tragédia grega, a contradição patética pode se dar no embate entre deuses (destino) e homens ou numa oposição presente no interior do homem ${ }^{310}$. As personagens de Gonçalves Dias, como na tragédia, são complexas e ambíguas e a sua heroína dramatiza conscientemente a angústia de sua condenação e o desenvolvimento de seu pathos até o desenlace fatal. A tragicidade não advém da alta categoria social das personagens, mas daquilo que Lesky chama de 'considerável altura da queda', a queda de um mundo ilusório de segurança e felicidade para um abismo de desgraças e é essa dissensão que estimula a dinâmica das ações. ${ }^{311}$.

A tragédia, por meio da representação de ações violentas descreve a desordem e a inevitável refundição dos valores primordiais da condição humana; "coloca-nos perante as consequências terríveis da luta pela afirmação da liberdade e da justiça ${ }^{312}$, à custa de escolhas que colocam o sujeito em crise, isto é, numa situação limite ou de ruptura." ${ }^{13}$ Para que haja impacto trágico, o herói deve sofrer conscientemente, pois, se, contrariamente, o destino apenas surpreende a vítima, não há tragicidade. Gonçalves

\footnotetext{
${ }^{309}$ SOUSA, Harlon Homem de Lacerda. Op. Cit., p. 68-69.

${ }^{310}$ LESKY, Albin. Op. Cit., 1976, p. 25.

${ }^{311}$ Idem, ibidem, p. 26

312 "Quase todas as tragédias que chegaram até nós tratam de questões relacionadas com o poder e a liberdade: a sua legitimidade ou a sua legitimação perante um poder maior, o dos deuses, e as consequências funestas que provoca uma acção afrontando a ordem humana regida pelos deuses. São acções de heróis e descendentes de deuses e a dimensão em que se movem não é sagrada, mas histórica: é o tempo dos heróis fundadores da Ática.” BRILHANTE, Maria João. Op. Cit., 2003, p. 205.

313 Idem, ibidem, 2003, p. 203.
} 
Dias evitou esse tipo de fatalidade "ex-machina" quando descartou o exemplo de tragédia proposto por Zacharias Werner ${ }^{314}$.

Em seu estudo sobre Emily Brontë, Bataille aproxima o romance Wuthering Heights $^{315}$ da tragédia grega no sentido de que o tema de ambos é essencialmente a transgressão trágica da lei ${ }^{316}$. A morte dos transgressores refletiria a supremacia do "Bem" como necessidade coletiva em detrimento da satisfação individual. No romance, Heathcliff e Catherine tentam sem sucesso perpetuar o idílio vivido na infância, um mundo sem coerções. Eles se recusam a renunciar à liberdade experimentada enquanto crianças, quando as convenções sociais ainda não exigiam a separação dos protagonistas. A transgressão é trágica porque se configura contra o "Bem", que se confunde com a ideia de razão baseada num sistema de cálculo que visa o interesse comum convencionado socialmente. Heathcliff não pode suportar esse sistema que de antemão o rejeita. Estereotipado como cigano, ele é considerado um incivilizado e está fadado à marginalidade, por isso o herói-vilão de Wuthering Heights se volta para o "Mal". O "Bem-razão" propõe, de forma calculada, o bem-estar da coletividade e o asseguramento do futuro. Já a embriaguez divina vivida no passado juvenil só pode ter sentido no presente. A preferência pelo presente relaciona-se ao "Mal" e é interdita às crianças, elas devem aprender a preparar-se para o futuro e assim alcançar a maturidade e o "Bem", ou seja, precisam se submeter às leis e convenções desse sistema racional. Mesmo que os protagonistas de Emily Brontë sejam coagidos a tomar parte das

314 "Na escola desses dramaturgos, o cego capricho do acaso chegou acoplado a dias e coisas funestas ( o 24 de fevereiro em Werner, o Quadro e o Farol em Houwald). O destino é aqui absolutamente sem motivo, enquanto o drama é compreendido como algo completamente motivado. NIETZCHE, Friedrich. Introdução à Tragédia de Sófocles. Rio de Janeiro: Jorge Zahar, 2006, p. 43.

315 Publicado em 1848, Wuthering Heights de Emily Brontë, traduzido em português por $O$ morro dos ventos uivantes, é considerado uma das obras mais importantes do Romantismo inglês. O enredo pode ser resumido como a história de um amor impossível entre Catherine Earnshaw e Heathclif, premido pelas convenções sociais. Heathcliff foi encontrado pelo pai de Catherine, Sr. Earnshaw, perdido e faminto nas ruas de Liverpool. O menino é levado para Wuthering Heights provocando os acontecimentos vindouros. $\mathrm{O}$ amor que o Sr. Earnshaw devota ao garoto provoca ciúmes em seu filho mais velho, Hindley. Já a filha, Catherine, torna-se companheira inseparável de Heathcliff. Com a morte do patriarca, Hindley vinga-se de Heathcliff negando-lhe conforto e educação. Catherine decide casar-se com o herdeiro da propriedade vizinha, Edgard Linton, indo ao encontro das normas da sociedade. Heathcliff desaparece por três anos e retorna rico, e disposto a se vingar dos Earnshaws e Lintons. O seu ódio contra os representantes das duas famílias recrudesce principalmente depois da morte de Catherine. BRONTË, Emily. O morro dos ventos uivantes. Trad. Raquel de Queiroz. São Paulo: Abril, 2010.

316 “Há em Wuthering Heights um movimento comparável ao da tragédia grega, no sentido de que o tema desse romance é a transgressão da lei. $\mathrm{O}$ autor da tragédia estava de acordo com a lei de que ele descrevia a transgressão, mas ele baseava a emoção na simpatia que sentia - e que, ao senti-la, transmitia - pelo transgressor da lei. A expiação, nos dois casos, está determinada na transgressão. Heathcliff conhece, antes de morrer, morrendo, uma estranha beatitude, mas esta beatitude amedronta, ela é trágica. Catherine, amando Heathcliff, morre por ter transgredido, senão na carne, no espírito, a lei da fidelidade; e a morte de Catherine é o 'perpétuo tormento' que, por sua violência, insensibiliza Heathcliff." BATAILLE, Georges. A literatura e o mal. Trad. Suely Bastos. Porto Alegre: L\&PM, 1989, p. 18. 
convenções estabelecidas (Catherine casa-se com Edgard Linton e Heathcliff torna-se um homem rico e 'civilizado'), a transgressão lhes é imanente e reverbera-se na morte da protagonista e na violência do vilão-herói. Ao morrerem, eles experimentam o arrebatamento que buscavam na duração do amor/infância. A morte e o êxtase são contrários às intenções do "Bem", já que são estados em que os planos para o futuro e a racionalidade não têm valor. ${ }^{317}$ "É sempre a morte - pelo menos, a ruína do sistema do indivíduo isolado à procura da felicidade na duração - que introduz a ruptura sem a qual ninguém acede ao estado de arrebatamento." 318

Leonor de Mendonça e Alcoforado também transgridem as leis sociais, e morrendo, eles reafirmam o "Bem" e o futuro. Assim como Catherine, a transgressão da duquesa de Bragança não ultrapassa os limites da intenção, mas a sua tentativa de fruir o presente lhe é negada. Alcoforado e Heathcliff são personagens que partilham a baixa condição social e, portanto, transgridem duplamente as leis sociais: eles tentam violar os preceitos definidos pela hierarquia social e, ao oferecerem o amor como arrebatamento, esses amantes, na verdade, vão contra o que prevê a preservação da sociedade. A plenitude do amor requer a ruptura: "A morte é a punição, procurada, acolhida, deste sonho insensato..." 319 . Ambos os apaixonados sabem que a morte é a única alternativa para conseguir transgredir as imposições que a racionalidade propõe. $O$ amor transfigura-se em morte, ou melhor, “(...) a morte aparentemente é a verdade do amor. Assim como o amor é a verdade da morte." 320 Vale lembrar que, diferentemente de Heathcliff que ardentemente deseja morrer e seguir Cathy, Leonor não deseja abrir mão da vida depois que Alcoforado é assassinado. O jovem mancebo, porém, já afirmara que estava disposto a tudo para que pudesse desfrutar apenas da atenção da duquesa.

\footnotetext{
ALCOFORADO (só, sentando-se) - Hoje enfim eu a verei sozinha! Talvez que ela por um instante se dispa dos seus preconceitos de orgulho e de nobreza para ouvir as palavras do mancebo que tão alto ousou elevar o seu pensamento; talvez que ela enfim se compadeça de meus sofrimentos, sofrimentos terríveis que eu tenho suportado sem murmurações, sem lágrimas. As murmurações poderiam despertar algum eco, e as lágrimas trairme!... Dir-lhe-ei tudo, e depois que me assassinem, que me assassinem aos pés dela, se o quiserem, que eu a bendirei morrendo. - (torna-se pensativo)
}

\footnotetext{
${ }^{317}$ Idem, ibidem, p. 21.

${ }^{318}$ Idem, ibidem, p. 23.

${ }^{319}$ Idem, ibidem, p. 18.

${ }^{320}$ Idem, ibidem, p. 12.

${ }^{321}$ DIAS, Gonçalves. Op. Cit., p. 937.
} 
Em relação à matéria escolhida por Gonçalves Dias, vale lembrar que a estrutura do acontecer histórico pode acolher a lei trágica, por isso, não há nenhum empecilho em fazer de um fato matéria para a tragédia. O trágico, segundo Aristóteles, surge da queda de uma posição de fortuna e prestígio que, por sua vez, advém de uma falha decorrente de um desconhecimento (hamartia), como no Édipo de Sófocles. Aliás, o filósofo grego adverte que essa falha não é moral como posteriormente se interpretou. Além disso, ele assevera que o herói trágico deve ter um caráter médio, não podendo ser totalmente censurável ou perfeito, para possibilitar, assim, a identificação do público. Não há ideia de culpa e expiação no trágico, porque a compaixão é suscitada pelo testemunho do infortúnio imerecido ${ }^{322}$. No prólogo da peça, G. Dias comenta que Leonor não tem crimes ou vícios que a desabonem, ela tem apenas defeitos que, aliás, são decorrentes da própria virtude. Quando quer ser agradecida e benevolente, ela é imprudente. Além disso, sua imprudência que poderia ser reconhecida como uma falha, nesse caso, um passo mal dado que acarreta seu infortúnio, diferentemente da tragédia clássica, trata-se de uma ação consciente ${ }^{323}$.

De qualquer maneira, a tragédia da duquesa não decorre de uma falta moral cometida por ela, mas da condição histórico-social em que ela vive. A partir do drama doméstico, o destino dos protagonistas vincula-se ao âmbito histórico-social, ou seja, eles sofrem porque fazem parte de determinada sociedade e em determinado tempo histórico ${ }^{324}$. E com Schiller, a tragédia passa a ser o meio para demonstrar o "poder moral", a liberdade do homem, resistindo ao sofrimento ${ }^{325}$.

Já a contenção (neo)clássica presente em Leonor de Mendonça deve-se (também) à preferência pela unidade de tempo e a restrição no que concerne a mudança de espaço. Os acontecimentos em cena se circunscrevem num período menor do que vinte quatro horas e os espaços, à propriedade do duque. No entanto, conforme

\footnotetext{
${ }^{322}$ LESKY, Albin. Op. Cit., p. 34-35.

323 "Tudo isso remete, evidentemente, à interpretação de hamartia, tal como sugerida pelos resultados das investigações que acabamos de apresentar, ou seja, a catástrofe virá, não como consequência de uma deficiência moral que se apresente como traço de caráter do agente do erro, mas por um erro involuntário, que irá desencadear os episódios causadores da catástrofe.” LUNA, Sandra. Op. Cit., p. 277, apud LIMA, Danielle Dayse Marques. Op. Cit., p. 114.

324 "Não existe uma ordem concebível de sociedade na qual um Hamlet ou um Antonius não seriam inevitavelmente atingidos pela desgraça e destruídos, ao passo que os heróis de Lessing e Schiller, Sara Sampson e Emilia Galotti, Ferdinand e Luise, Carlos e Posa, poderiam ser felizes em qualquer outra sociedade e em qualquer outra época que não a deles, ou seja, que não a de quem os criou." HAUSER, Arnold. Op. Cit., p. 593.

${ }^{325}$ MACHADO, Roberto. Op. Cit., p. 56.
} 
comentário anterior, mesmo o espaço sendo circunscrito às redondezas do palácio ducal, há uma distinção entre a casa de Alcoforado e o palácio.

Os eventos ocorridos em outros espaços, como no caso da caçada, bem como os acontecimentos do passado, sobretudo os infortúnios da juventude do duque, são narrados. Dessa forma, eles são restringindos ao domínio do discurso, do extracênico, o que faz com que a ação seja condensada. Vale lembrar que a dramaturgia romântica, embora quisesse incorporar o teatro descontínuo shakespeariano, estava submetida à ideia de continuidade histórica. A solução foi optar preponderantemente pela ruptura espacial e a unidade temporal ${ }^{326}$.

\begin{abstract}
A unidade de tempo, isto é, essa confrontação do tempo real com o tempo psíquico, corta nos dois extremos a temporalidade das relações humanas, quer se trate da duração sócio-histórica ou da duração vivida, individual, das relações dos homens e de seu passado, do retorno do passado como reprimido. Daí, no teatro clássico, a canalização de toda a densidade temporal para o extracênico: é no extracênico, isto é, no discurso das personagens que se lê a relação do indivíduo com a história. ${ }^{327}$
\end{abstract}

Segundo Ubersfeld, independente do modo de representação, sempre há no texto teatral uma dialética entre unidade e descontinuidade. Mesmo na tragédia antiga o nãotempo pressupõe um tempo abolido, um outro tempo, um tempo de referência que pode ser valorizado ou desvalorizado, mas que sempre comporta uma catástrofe, ou seja, o desfecho trágico é o desdobramento desse tempo-referência ${ }^{328}$. Em Leonor de Mendonça, as narrativas das personagens principais trazem o passado à tona, o qual contém em germe a tragédia do presente. O passado de d. Jaime é o exemplo mais claro dessa assertiva, porque não apenas "justifica" o desenlace trágico, mas prefigura a tragédia.

Com base no excerto de Lesky a seguir, pode-se inferir que G. Dias conseguiu absorver a essência do trágico ao penetrar no acontecimento histórico e configurá-lo de forma que, ao torná-lo "sensível", as "forças espirituais" inerentes ao fato representado emergem. Ademais, o drama não existiria sem a tragédia grega ${ }^{329}$.

O espírito enformador penetra através do acontecer caótico, e a configuração artística, que de modo algum é puramente técnico-formal, eleva o

\footnotetext{
${ }^{326}$ UBERSFELD, Anne. Op. Cit., 2005, p. 130.

${ }^{327}$ Idem, ibidem, p. 127.

${ }^{328}$ Idem, ibidem, p. 130-131.

${ }^{329}$ LESKY, Albin. Op. Cit., p. 238.
} 
representado à esfera do sensível e torna visíveis as forças espirituais que se encontram por trás dos acontecimentos. ${ }^{330}$

${ }^{330}$ LESKY, Albin. Op. Cit., p. 67. 


\title{
3.4 Elementos byronianos e góticos
}

\begin{abstract}
$\mathrm{Na}$ tua paciente energia, na resistência e na revolta do teu invencível Espírito, que nem a Terra nem o Céu puderam abalar, herdamos nós uma poderosa lição; tu és para os Mortais um símbolo e um sinal do seu destino e da sua força. Como tu, o Homem é em parte divino, um turvo rio nascido de uma fonte pura; e o Homem pode prever fragmentariamente o seu destino mortal, a sua miséria, a sua revolta, a sua triste existência solitária, ao que o seu Espírito pode opor a sua essência à altura de todas as dores, uma vontade firme e uma consciência profunda que, mesmo na tortura, pode descobrir a sua recompensa concentrada em si própria, pois que triunfa quando ousa desafiar e porque faz da Morte uma Vitória.
\end{abstract}

(Byron, Cain, III, I)

Jacobbi observa que Dias absorvera o byronismo de temática neo-elisabetiana ${ }^{331}$, mística ou sádica, dos ingleses e, sobretudo, dos alemães, dentro de uma técnica ainda "clássica e aristotélica"332. Embora as razões dessa assertiva sejam explicitadas resumidamente, infere-se que o byronismo em L.M. se reverbera na figura do herói apaixonado que desafia as convenções sociais e se autodestrói, na feição um pouco demoníaca de um duque sedento por sangue, na atmosfera de morte fortemente marcada nas falas, sobretudo as do jovem Alcoforado ${ }^{333}$ e de d. Jaime, as quais expressam os augúrios dos infortúnios desde o início da peça. Já Leonor, a vítima, representaria o estereótipo advindo dos romances góticos da "perseguida". Alcoforado assume, em parte, a figura do homem fatal, no sentido de que o seu amor causa a destruição da mulher amada ${ }^{334}$.

A literatura gótica e a romântica são cronologicamente próximas e dividem alguns temas e características, como o herói transgressor, cujo processo mental interior é explorado em detrimento das ações exteriores. Pode-se notar que nos romances góticos a exposição da interioridade das personagens avança em relação às criações de

\footnotetext{
${ }^{331}$ Kilgour assevera que o gótico é construído com base em diversas fontes: folclore britânico, baladas, romances, tragédias elizabetianas e jacobianas (especialmente as de Shakespeare), Spenser, Milton, ideias renascentistas sobre melancolia, "graveyard poets", Ossian, o sublime, os novelistas sentimentalistas (Prévost, Richardson e Rousseau), tradições germânicas (especialmente Die Raüber e o Visionário de Schiller). KILGOUR, Maggie. The Rise of the Gothic Novel. London; New York: Rotledge, 1995, p. 4. 332 JACOBBI, Ruggero. Op. Cit., p. 68-69.

333،AALCOFORADO - E fora maravilha que me compreendêsseis!... Falar-vos-ei, pois claramente. Bem sabeis que eu parto amanhã; o que, porém, vós não sabeis é que desde criança um pensamento fatal se enraizou profundamente na minha alma. Não viverei muito! [...]” DIAS, Gonçalves. Op. Cit., p. 950.

${ }^{334}$ No Romantismo, o modelo de amor terno e conjugal será contraposto ao de amor sádico e masoquista. Mario Praz define algumas características do homem fatal, inspirado em Lord Byron: nobre, belo, misterioso e decaído, com olhos penetrantes, tristes e inesquecíveis, ele seduz e destrói as suas vítimas apesar de sua aparente fragilidade. No teatro romântico, Antony de Alexandre Dumas é um exemplo paradigmático do homem fatal. Sobre o tema, consultar: PRAZ, Mario. Op. Cit., p. 7-91.
} 
Richardson, nos sentido de que, naqueles, as ações dos caracteres passam a ser mais complexas do que um simples impulso seguido de remorso. As narrativas góticas não exibem apenas os bons sentimentos de seus heróis ou heroínas. As personagens assumem um caráter ambíguo, muitas delas expressam grandeza de caráter que, devido às circunstâncias, é empregada para fazer o mal. $\mathrm{O}$ vilão-herói vai sempre contra a norma estabelecida e é sempre contrastado a outra personagem que, contrariamente, representa essa ordem. O leitor é, ao mesmo tempo, repelido pelo sadismo e envolvido pela trágica história de vida de figuras como Melmoth, Frankenstein, Heathcliff, Ahab etc $^{335}$.

\begin{abstract}
He [Ahab] is a figure of immense stature, a good man, a kindly man of real humanity (witness his relations with Starbuck), but a man gripped by a deadly monomania which will destroy him and his companions with him. [...] Ahab is a madman, and yet he remains a complex and tragic figure. [...]Both books [Moby Dick e Wuthering Heights] leave us with great ambiguities; good and evil, love and hate are intertwined until they are inseparable. Motives which we might praise or blame without a second thought in our everyday worlds appear to us in the Gothic context as beyond judgment. We are brought to see the hurts of Ahab and Heathcliff, to appreciate their complexities, and ultimately to decline judgment on the damage they do to themselves and to others. ${ }^{336}$
\end{abstract}

No drama em questão, d. Jaime é a personagem que mais se aproxima das características do herói-vilão gótico, pois, apesar de injustamente matar a esposa e o suposto amante, a sua história e o seu sofrimento não deixam de compadecer o leitor/espectador. O seu desejo de vingança, a desconfiança permanente e os "acessos nervosos" assemelham-se aos do monomaníaco Ahab. Contudo, é preciso atentar para o fato de que o duque, mesmo sendo uma figura ambígua, representa a ordem estabelecida $^{337}$. Contudo, ele gostaria de seguir suas escolhas, contrárias às convenções sociais. Vale lembrar também que seu poder, quase tão amplo como o do rei, infunde terror. Quando analisa a relação entre a grandiosidade e o sublime, Burke assinala que a

\footnotetext{
${ }^{335}$ HUME, Robert D. Gothic versus Romantic: A Revaluation of the Gothic Novel. PMLA. vol. 84, n. 2. Mar., 1969, p. 282-290. Disponível em: http://www.jstor.org/stable/1261285. Acesso em: 22 out. 2013. 336 Idem, ibidem.

337 "A tirania encarnada pelo vilão é frequentemente associada por uma parte da crítica especializada à metáfora de uma sociedade arcaica, cujo poder concentrava-se nas mãos dos senhores e do clero, que perde paulatinamente seu espaço para um novo tipo de organização emergente no século XVIII". MENON, Maurício César. Figurações do gótico e de seus desmembramentos na Literatura Brasileira de 1843 a 1932. Londrina, 2007. Tese (Doutorado em Letras), Programa de Pós-Graduação em Letras, Universidade Estadual de Londrina, p. 37.
} 
dor, nesse caso, é infligida por uma força superior que impressiona, e o poderio dos reis e governantes causam a mesma sensação $0^{338}$.

Ao final do drama a atitude do duque de Bragança excede o âmbito da vingança ou de defesa da honra do marido traído ${ }^{339}$. De forma sádica ${ }^{340}$, ele se compraz em executar a esposa como deixa transparecer a ironia de suas falas: "O DUQUE - (em voz alta) - A filha de D. João de Gusmão, duque de Medina Sidônia, conde de Niebla, marquês de Cazaça e senhor de Gibraltar, merece contemplação pela sua hierarquia. (à Duquesa) - Não vos parece?”341; “O DUQUE - E do céu é que vem esta inspiração, Sra. Duquesa. Alegrai-vos... tereis um duque por carrasco!"342

Menon $^{343}$ assinala que o herói gótico não é tão relevante quanto os outros protagonistas. Com caráter linear e previsível, esse herói reflete atributos do cavaleiro medieval, como possuir extrema bondade, ser devoto e piedoso. A pusilanimidade dos protagonistas pode ser vislumbrada no fato de, na literatura gótica, serem os antagonistas chamados de vilão-herói, porque é nele que se concentra a narrativa e a atenção do leitor. Alcoforado descende dessa linhagem. Mas, contrariamente ao herói gótico, ele não salva a heroína. Antônio Alcoforado é antes um dos elementos que propulsiona a "falha" da protagonista e a sua ruína. O jovem não se coaduna à ordem social estabelecida, pelo contrário, ele morre na tentativa de desafiá-la. Assim, socialmente inferiorizado e moralmente superior, Alcoforado conjuga o dualismo típico dos heróis românticos. Arrogante, ele quer arrebatar Leonor, para juntos, por meio do sentimento mais sublime, o amor, erguerem-se acima do ordinário, acima da vida ${ }^{344}$. Vale observar mais uma vez que Leonor não compartilha esse desejo.

A heroína gótica (e também a heroína do romance sentimental), em suma, a perseguida, provavelmente também descende das personagens das novelas de cavalaria, no sentido de que ela é exposta a uma situação de perigo. Nos textos cavaleirescos, a protagonista é salva pelo herói cavaleiro que apresenta um caráter irrepreensível e

\footnotetext{
${ }^{338}$ BURKE, Edmund. Op. Cit., p. 54.

339 "O DUQUE - [...] Agora, porém, confessais a minha prepotência, e tendes em dúvida para vós que, se como homem me injuriastes, eu como senhor me vingo!... Apesar de vos abaixardes tanto, senhora..." DIAS, Gonçalves. Op. Cit., p. 965.

340 "Ao passo que, no sadismo, trata-se de ter prazer com a destruição contemplada, a destruição mais amarga sendo a morte do ser humano. É o sadismo que é o Mal: se se mata por um proveito material, não é o verdadeiro Mal, o Mal puro, já que o assassino, além do proveito obtido, tem prazer em ter ferido." BATAILLE, Georges. Op. Cit., p. 14.

${ }^{341}$ DIAS, Gonçalves. Op. Cit., p. 967

${ }^{342}$ Idem, ibidem.

${ }^{343}$ MENON, Maurício César. Op. Cit., p. 102.

${ }^{344}$ PRADO, Décio de Almeida. Op. Cit., p. 179.
} 
altruísta. Dessa forma, a heroína serve como meio para enaltecer a figura do cavaleiro. $\mathrm{Na}$ narrativa gótica esse esquema é modificado. A heroína, exemplo de virtude, passa a representar o contraponto do vilão. A sua figura é sempre relacionada ao espaço, este significando o subjugo em relação à dominação masculina ${ }^{345}$, seja por meio do enclausuramento ou de perseguições inflamadas por paixões desenfreadas.

Kilgour distingue duas leituras críticas em relação à situação em que a heroína é colocada nos romances góticos. Uma delas entende essa conjuntura como uma subversão da ordem, que é seguida pela restauração da norma, a qual, depois da experiência de terror vivida, passa a ser imensamente desejável ${ }^{346}$. Outra interpretação vê o gótico como um gênero que provê um enredo de "subversão feminina", pois a evasão do mundo real aventada pelo gênero dá à literatura a possibilidade de indiretamente criticar as coisas como elas são. Nesse sentido, subentende-se que a partir da literatura gótica o lar passa a ser visto como uma prisão, na qual a mulher indefesa fíca à mercê da violenta autoridade patriarcal, revelando as contradições intrínsecas à sociedade burguesa ${ }^{347}$.

Leonor assemelha-se às heroínas sentimentais e também é submetida a uma espécie de perseguição pelo marido. D. Jaime aterroriza a esposa seja por meio de seus ataques involuntários, seja por sua simples presença. No entanto, assim como suas predecessoras sentimentais e góticas, a duquesa deixa entrever outra possibilidade de ação em que as amarras sociais representadas pela figura do marido e do espaço em que coabitam seriam transgredidas.

\footnotetext{
...[Os] romances sentimental e gótico brincam perigosamente, para uma época que tanto se empenhou em sublinhar a nova moralidade, com a exposição de suas heroínas a situações 'de risco' (como o incesto ou o estupro), fazendo-as caminhar no fio da navalha que poderá levá-las à perdição. Ao pôr a virtude de suas personagens à prova, mesmo que seja para reafirmá-la, triunfante, ao final, excitam a imaginação do leitor e deixam vir à tona o avesso da moral que proclamam, revelando a 'sombra' que esta derivação do romanesco - o gótico - saberá tão bem encampar. ${ }^{348}$
}

\footnotetext{
${ }^{345}$ MENON, Maurício César. Op. Cit., p. 102.

346 "The gothic forms of domesticity evaporate, enabling the heroine to return to the real version, now purified of its contaminated forms, so that women's continuing incarceration in the home that is always the man's castle is assured." KILGOUR, Maggie. Op. Cit., p. 38.

${ }^{347}$ Idem, ibidem, p. 9.

${ }^{348}$ VASCONCELOS, Sandra Guardini. Op. Cit., 2007, p. 133.
} 
Além disso, Punter ${ }^{349}$ assevera que a sociedade que gerou e leu a ficção de cunho gótico se caracteriza por se tornar consciente das injustiças perpetradas em diferentes áreas, como a desigualdade na relação entre gêneros. Essa temática perpassará a literatura romântica, como ilustra Leonor de Mendonça. Aliás, no gótico, as relações humanas, levadas ao extremo da violência e da destruição, tornam-se desfamiliarizadas, causando estranhamento e horror. $\mathrm{O}$ tema do incesto ${ }^{350}$ adotado na $^{2}$ literatura de terror e na romântica, por exemplo, contém a ideia de um desejo anormal e extremado que vai de encontro aos padrões sociais, violando os laços familiares. No entanto, quando se expõe o que seria o oposto do que a sociedade almeja, contraditoriamente se reproduz uma forma exacerbada da relação que realmente se $\operatorname{deseja}^{351}$.

Outra característica da literatura de terror que se reflete no Romantismo, e parece ser bastante importante para a caracterização das personagens de Leonor de Mendonça, é o interesse pela infância como determinante para a vida adulta. Segundo Kilgour ${ }^{352}$, a relevância desse período da vida deve-se ao crescimento do interesse pela individualidade e pelo passado histórico. Pensadores como Locke passam a ver essa etapa como um estágio de formação. A ideia de que a criança nascia corrupta e deveria ser redimida por meio da educação vai sendo substituída pelo idealismo rousseaniano, no qual o princípio anterior é subvertido: nasce-se inocente e depois se é corrompido pela sociedade ${ }^{353}$. Também a liberdade experimentada durante a puerícia é oposta à escravidão da maturidade, assim como a liberdade individual se contrapõe às normas sociais. De qualquer forma, a infância é vista como o período que determina a identidade do indivíduo.

No gótico, essa tendência se coaduna com o interesse por estados mentais anormais. Assim, criam-se personagens que não amadurecem e tornam-se excêntricas, e cujo desenvolvimento não é teleológico, mas compulsivo e caracterizado pela repetição.

\footnotetext{
349 PUNTER, David. The Literature of Terror: a History of Gothic Fictions from 1765 to the Present Day, New York: Longman, 1980, p. 127.

350 Vale lembrar que Gonçalves Dias se apropria da temática do incesto associada com a de reclusão em outro drama, Beatriz Cenci.

${ }^{351}$ KILGOUR, Maggie, Op. Cit., p. 12.

${ }^{352}$ Idem, ibidem, p. 34-36.

353 Um exemplo célebre dessa concepção rousseauniana de infância pura seria o monstro de Frankenstein: "Mary Shelley is here concerned to present the monster in the light of Rousseauistic and Godwinian theories, as born innocent, a tabula rasa, a being who well have his psyche formed by his contacts with circumstance." PUNTER, David. Op. Cit., 1980, p. 124.
} 
Elas permanecem presas ao passado e não se desenvolvem. O gótico, nessa perspectiva, seria uma versão distorcida do Bildungsroman.

Essa visão da infância como fator determinante da individualidade (e do destino) perpassa o drama gonçalvino. Os problemas vividos na infância dos protagonistas da peça interferem no desenvolvimento das personalidades e colaboram para o desfecho trágico. O jovem Alcoforado possui uma família que o ama, mas há, nessa estrutura, a ausência da mãe e o drama sugere que o amor que ele sente pela duquesa se relaciona com essa carência. Nessa busca por um amor impossível, seja o da mãe ou de Leonor, Alcoforado sabe que não terá uma existência longa, lançando-se para o abismo da morte. A duquesa de Bragança sofreu a falta dos pais e de tudo que amava, pois devido ao casamento com d. Jaime, ela foi obrigada a deixar sua casa ainda criança. $\mathrm{O}$ (futuro) marido mostrou-se gentil, mas nunca a amou e é principalmente pela ausência de amor que ela sofre. No entanto, o duque é a personagem que mais se aproxima do modelo gótico, pois os acontecimentos vividos na infância moldaram-lhe um caráter irascível e compulsivo. Os traumas infantis são obsessivamente relembrados. Os ataques frequentes mostram que, somente repetindo a violência experimentada, ou seja, derramando sangue, ele se sente aliviado. Note-se que mesmo a atividade da caça, um dos subterfúgios utilizados pelo duque para acalmar seus nervos, pressupõe a ideia de matar. Ademais, as suas falas refletem a compulsividade de suas ações porque se caracterizam pelos imperativos, pelo uso dos sinais de pontuação e pela repetição das palavras, como em: “- Falai! Falai!”; “- Estúpido! Estúpido! Estúpido!”; “- Eu estava sufocado! (...) - Sangue!... Sangue!... Sangue!”; “- Morrereis!.... Morrereis!...”, dentre outras.

A afinidade entre a literatura gótica e a romântica também pode ser percebida nas preferências em relação à seleção do espaço e do tempo. Os lugares e períodos preponderantemente empregados em narrativas góticas e, posteriormente, nos dramas históricos são: sul da França, Espanha, Itália ou Alemanha durante o século XVI. De fato, na literatura gótica não há uma preocupação com relação à caracterização espaçotemporal (diferentemente do romance e de grande parte dos dramas históricos). Essencial aí é a noção de distanciamento, o tempo e o espaço devem estar distantes do século coetâneo e apresentarem uma atmosfera assustadora e ambígua. Na peça em questão, a demarcação histórica do tempo e do espaço é importante não só por se tratar de uma característica do drama baseado em acontecimento verídico, mas também por 
contribuir com o significado social que a obra abrange ${ }^{354}$. É preciso aclarar que o abrandamento do contorno espaço-temporal reduziria o sentido de embate social tanto do ponto de vista de classe como do ponto de vista de gênero que a luta entre os três protagonistas configura 355 .

Vale lembrar que a já comentada ambiguidade subsumida na figura do heróivilão gótico inicia a tendência romântica para o duplo, o obscuro, o caótico, o demoníaco e dionisíaco, que pode ser lida como uma forma de expressar a insuficiência da razão (e da religião) em compreender a realidade e o sujeito. O romântico descobre o inconsciente que explica a existência de tendências e desejos que a razão rejeita. Assim, o psicologismo, que a literatura sentimental e a gótica ensaiaram, e que culminou na literatura moderna é bastante presente no Romantismo. No caso de Leonor de Mendonça, é nítida a preocupação do autor em apresentar personagens não lineares, sobretudo o casal de duques. D. Jaime e d. Leonor ora agem de acordo com a razão conformando-se às regras sociais, ora agem irracionalmente movidos por desejos, paixões e traumas infantis. Por sua vez, Alcoforado, apaixonando-se pela duquesa, atua movido por um desejo que não pode explicar, mas sentir.

\begin{abstract}
[O romântico] Descobre que 'duas almas habitam em seu seio', que algo em seu íntimo sente e pensa não ser idêntico a si mesmo, ele carrega consigo seu demônio e seu juiz - em suma, descobre os fatos básicos da psicanálise. Para ele o irracional tem a inestimável vantagem de não estar sujeito ao controle consciente, motivo pelo qual enaltece o inconsciente, os instintos obscuros, os estados oníricos, os devaneios e êxtases da alma, e busca neles a satisfação que não lhe é assegurada pelo frio e crítico intelecto. ${ }^{356}$
\end{abstract}

Novamente, é a figura de d. Jaime que apresenta de forma mais pungente um caráter dúbio, excêntrico, terrível. $\mathrm{Na}$ cena III do I Ato, o duque mostra-se compreensivo e preocupado com a esposa. Consciente de seus defeitos, ele sugere a Leonor que volte para a corte. Logo depois dessa prova de consideração, começa a atemorizar a consorte com mais uma de suas crises e um sinistro discurso premonitório. Aliás, é sintomático (e irônico) que ele informe a própria Leonor que uma fatalidade recairá sobre a família, dizimando uma vítima: “O DUQUE - (...) A minha insônia

\footnotetext{
${ }^{354}$ Punter assinala que na produção literária gótica é possível encontrar engajamento político e social, a dificuldade em negociar essas questões podem ser visualizadas na própria convenção estilística do gênero que reage contra toda a sobriedade do período anterior. Die Räuber de Schiller foi a fonte do 'gótico político', principalmente a figura de Karl Moor, símbolo de aspiração pela liberdade que inspirará o herói byroniano. Idem, ibidem, p. 61-62 e 65-66.

${ }^{355}$ Adiante, no capítulo "Sobre o tempo e o espaço", as características góticas nos elementos espaçotemporais presentes no drama em questão serão discutidas de forma mais pormenorizada.

${ }^{356}$ HAUSER, Arnold, Op. Cit., p. 679-680.
} 
desta noite, as duas mortes de que escapastes, fazem-me crer que uma fatalidade sobrevirá hoje à minha família. Não o duvideis!... Será o terceiro golpe o mais terrível! A vítima não escapará." 357

${ }^{357}$ DIAS, Gonçalves. Op. It., p. 928. 


\subsection{0 drama histórico}

Com as mudanças decorrentes da Revolução Francesa, um fixismo ${ }^{358}$ histórico deixou de ser plausível. Na França, por exemplo, a monarquia deixou de ser um modelo de legitimidade e paradigmas políticio-sociais antigos como os dos romanos, gauleses e francos passaram a ser estudados. Além disso, o interesse pelo passado condicionou uma historiografia menos factual, pois os historiadores tinham também a ambição de apresentar ao povo uma perspectiva do passado como lição para o presente. ${ }^{359}$

Sobre o recrudescimento da paixão pela história, que se reverbera no teatro e na literatura, Roubine o explica com base no advento da Revolução Francesa, cujas reviravoltas sociopolíticas teriam gerado uma sensação de aceleração do tempo e o desejo de compreender o presente recorrendo-se ao passado. "Além disso, o indivíduo comum acaba de descobrir que não é mais apenas o espectador de uma história representada, em um palco distante, entre soberanos e grandes senhores feudais. Agora nolens volens, ele se descobre ator!" 360

Também devido à propagação das ideias herderianas sobre o caráter evolutivo da história e dos povos, cada qual encerrando suas idiossincrasias, assume-se que toda época tem sua particularidade. Ao historiador cabe a tarefa de não só explicar, mas tornar a história visível ao leitor.

As artes, na estética romântica, apreendem esse interesse pela história e a veem com um viés trágico, dramático. A explosão do drama histórico foi precedida por uma reflexão sobre a capacidade do teatro de escrever história como asseveram as 'scènes historiques' escritas por Ludovic Vitet durante a Restauração na França. Nessas cenas, a história era escrita de maneira viva e expressiva, empregando a cor local, várias personagens e dispersão espaço-temporal, o que teria, aliás, incentivado a quebra das unidades de espaço e tempo no drama ${ }^{361}$. Concomitantemente, ao descrever eventos históricos, importantes historiadores, como Thierry, Villemain e Cousin, utilizam-se de termos relativos ao teatro aproximando a história à lógica do drama, ou seja, à ideia de

358 Teoria que explica a origem e a diversidade das espécies como fixas e imutáveis opondo-se ao darwinismo.

${ }^{359}$ NAUGRETTE, Florence. Op. Cit., p. 57.

${ }^{360}$ ROUBINE, Jean Jacques. Introdução às grandes teorias do teatro, Trad. André Telles, Rio de Janeiro: Zahar, 2003, p. 87.

${ }^{361}$ NAUGRETTE, Florence. Op. Cit., p. 58-60. 
conflito $^{362}$. Vale lembrar que, antes do século XVIII, a história era tida como uma fonte de exemplos morais, por isso a fidelidade dos registros em relação aos eventos ou processos históricos não era prioridade: “A história não é ciência, é material permitindo enformar a prudência." 363

A história traz a realidade para a literatura em detrimento do estereótipo, a intriga passa a ser inserida numa determinada realidade social e a psicologia das personagens torna-se aparente por meio de diálogos verossímeis ${ }^{364}$. Nos dramas históricos, além da valorização da cotidianidade e da célula familiar como núcleo da intriga central advinda do drama burguês, os românticos incluem a inclinação aos enredos históricos, ou melhor, os destinos individuais e as transformações históricas são interligados.

O drama histórico não propõe apenas um julgamento retrospectivo do evento representado, mas expressa também uma determinada teoria sobre o desenvolvimento da história. Já durante o Iluminismo, a visão de base judaico-cristã que via a história como um ciclo em que o poder divino manifesta-se intervindo continuamente no mundo desde sua gênese é substituída pela ideia de que as instituições, costumes e normas sócio-jurídicas são um produto pontual, ou seja, historicamente marcado, do contrato social entre os seres humanos ${ }^{365}$. Com o advento do romantismo, o acontecer histórico passou a ter um viés progressista e a noção de tempo algo positivo, pois permite a novidade e o progresso, rompendo, assim, com o conceito de história como evento cíclico e elenco de exemplos morais retirados dos feitos de personagens ilustres ${ }^{366}$.

A perspectiva romântica funde as sociedades em mundos, comunidades, nações, raças que compreendem uma identidade, não de cada indivíduo, mas coletiva. Dessa forma, mesmo que idealisticamente, o movimento romântico aproxima-se das diferentes realidades, dos fenômenos dos tempos característicos, dos diversos espaços ambientais, conferindo-lhes cor local. Instaura-se um discurso radicado em

\footnotetext{
362 "O teatro não podia ficar muito tempo indiferente a essa moda [de evocação da História]. Ainda mais que os historiadores contemporâneos não param de se referir a essa arte, vendo nos episódios agitados com que lidam ações igualmente dramáticas. A vida de Cromwell é, segundo Villemain, 'um grande espetáculo'. Para Augustin Tierry, a conquista da Inglaterra pelos normandos foi 'um grande drama que teve como teatro a ilha da Bretanha'. Finalmente, aos olhos de Victor Cousin, é toda a vida da humanidade que se encadeia, segundo uma lógica teatral, como uma sucessão de 'dramas'..." ROUBINE, Jean-Jacques. Op. Cit., p. 88.

${ }^{363}$ RIBEIRO, Renato Janine. História e revolução: a Revolução Francesa e uma nova ideia de história. Revista USP, v. 1, 1989, p. 14.

${ }^{364}$ MORETTO, Fulvia M. L. Victor Hugo e o Romantismo. Lettres Françaises, n. 5, 2003, p. 12.

${ }^{365}$ GUINSBURG, J. In: GUINSBURG, J. (Org). Op. Cit., 1985, p. 14-15.

${ }^{366}$ RIBEIRO, Renato Janine. Op. Cit.,3 p. 12-18.
} 
particularismos, os quais são quase sempre envolvidos por um viés mitificante. Cada povo, país ou nação teria uma finalidade que dirigiria o sentido de sua existência. A verdade de cada povo, no entanto, não seria apreensível só pela razão, o sentimento e a intuição serviriam como guia para as suas realizações. Nesse sentido, a história é pensada como um fim em si mesmo.

O sentido histórico passa a sintetizar-se na história em si. Os eventos são singulares e não dependem de uma categorização ou determinação causal para serem valorizados. Dessa maneira, aquilo que era excluído da historiografia passa a ser considerado como elemento estrutural, daí a inclusão das histórias dos camponeses, operários, transgressores da lei e da religião, bem como dos socialmente alienados. $\mathrm{O}$ discurso histórico deixa de ser descritivo para ser interpretativo e formativo. A via fenomenológica ${ }^{367}$ e histórica começa a impor-se e deslocar-se para as 'medianias', revelando o homem contingente e as vicissitudes de seu contexto ${ }^{368}$. Compreende-se por que na literatura os fatos históricos de diferentes nações, não mais os do mundo clássico, bem como as particularidades espaço-temporais entram em voga. Igualmente, entre os protagonistas passam a ser incorporados representantes das classes secundárias e dos alienados da sociedade.

O desenvolvimento da história moderna, outrossim, se refletiria num sentido pedagógico que o teatro ainda se atribui. $\mathrm{O}$ teatro tornaria a história mais palpável e, dessa forma, o público vislumbraria a correlação das causas e dos efeitos do processo histórico. Nesse sentido, o evento do passado é escolhido em função da semelhança com a situação política coetânea. Havia, aliás, uma preocupação com a pesquisa histórica, embora esses dramas nos pareçam claramente fantasiosos. Prado, por exemplo, afirma que não há nada tão a-histórico quanto o suposto teatro histórico de Alexandre Dumas e Victor Hugo, já que o passado só parece justificar a exploração da atualidade ${ }^{369}$.

Pode-se dizer que os românticos intentaram conformar, na representação romântica da história, realismo mimético e liberdade poética ${ }^{370}$. Essa autonomia para a criação é que diferenciaria o poeta do historiador. Caberia ao artista trabalhar com as entrelinhas, ou seja, onde há incertezas no campo histórico, o poeta pode deliberadamente criar. Ao artista compete exprimir os sentimentos, as motivações e os

\footnotetext{
367 Com o historicismo, a história passa a requerer um status de cientificidade baseando-se na interpretação da experiência e levando em consideração a cultura do período em que os fatos ocorrem e não valores morais permanentes.

${ }^{368}$ GUINSBURG, J. In: GUINSBURG, J. (Org). Op. Cit., 1985, p. 14-21.

${ }^{369}$ PRADO, Décio de Almeida. In: GUINSBURG, J. (ORG.). Op. Cit., 1985, p. 182.

${ }^{370}$ ROUBINE, Jean-Jacques. Op. Cit., p. 99.
} 
comportamentos por trás dos elementos factuais da história. Além disso, como para os românticos o passado remeteria ao presente, o drama burguês, o melodrama e a cena histórica seriam gêneros afins no sentido de que todos abrangeriam o real histórico e contemporâneo.

Conforme mencionado, os autores românticos consideravam o teatro a forma mais efetiva de difundir a história, por meio dele o povo pode conhecer a sua própria evolução, o seu ethos. No entanto, o fato histórico é, muitas vezes, apenas empregado de maneira panorâmica, pois o verdadeiro objetivo do drama histórico é revelar a intimidade dos caracteres, seus hábitos e seus sentimentos. Acredita-se que, dessa forma e através da verossimilhança, constrói-se uma verdade mais profunda que a da história.

\begin{abstract}
Quando o caracter dos indivíduos ou das nações é suficientemente conhecido, quando o os monumentos e as tradições, e as chronicas desenharam esse caracter com pincel firme, o novelleiro póde ser mais verídico do que o historiador, porque está mais habituado a recompor o coração do que é morto pelo coração do que vive, o gênio do povo que passou pelo do povo que passa. Então de um dicto, ou de muitos dictos elle deduz um pensamento ou muitos pensamentos, não reduzidos à lembrança positiva, não traduzidos, até materialmente; de um facto ou de muitos factos deduz um affecto ou muitos affectos, que se não revelaram. Esta é a história íntima dos homens que já não são: esta é a novella do passado. Quem sabe fazer isto chama-se Scott, Hugo, ou De Vigny, e vale mais, e conta mais verdades, que boa meia-dúzia de bons historiadores." ${ }^{371}$
\end{abstract}

Conforme foi dito anteriormente, para a nova perspectiva, a história obedeceria a uma lei progressista, ou seja, o passado proporcionaria orientações para o futuro, não só para os representantes do povo, mas para todo o povo. Dessa forma, ficcionistas românticos como Herculano optavam por buscarem no passado heróis que representassem o coletivo. Essas noções reverberam a questão do caráter pedagógico da literatura romântica como forma de revelar e propagar aos homens os valores nacionais reintegrando-os ao passado.

Victor Hugo, semelhantemente, assevera que o poeta expressa a verdade sobre os fatos truncados pelos analistas, reparando as omissões e lacunas e revestindo-os com uma forma poética e, ao mesmo tempo natural. O poeta torna-se, nesse sentido, um verdadeiro demiurgo, pois tem a capacidade de recriar e criar através da arte:

371 O PANORAMA: jornal literário e instrutivo da Sociedade Propagadora de Conhecimentos Úteis (1837-1844), Lisboa: Imprensa da Sociedade Propagadora de Conhecimentos Úteis, 1840, p. 243. In: VASCONCELOS, Ana Isabel. O tratamento da História no drama romântico português. Limite: Revista de estúdios portugueses y de la lusofonia, Universidad de Extremadura, $\mathrm{n}^{\circ}$ 2, 2008, pp.79-95. Disponível $\mathrm{em}$ : http://dialnet.unirioja.es/servlet/articulo?codigo=2976423. Acesso em: 22 fev. 2010. 
O teatro é um ponto de ótica. Tudo o que existe no mundo, na história, na vida, no homem, tudo deve e pode aí refletir-se, mas sob a varinha mágica da arte. A arte folheia os séculos, folheia a natureza, interroga as crônicas, aplica-se em reproduzir a realidade dos fatos, sobretudo a dos costumes e dos caracteres, bem menos legada à dúvida e à contradição que os fatos, restaura o que os analistas truncaram, harmoniza o que eles desemparelharam, adivinha suas omissões e as repara, preenche suas lacunas por imaginações que tenham a cor do tempo, agrupa o que deixaram esparso, restabelece os fios da providência sob as marionetes humanas, reveste o todo com uma forma ao mesmo tempo poética e natural e lhe dá esta vida de verdade e de graça que gera a ilusão, este prestígio de realidade que apaixona o espectador, e primeiro o poeta, pois o poeta é de boa fé. Assim, a finalidade da arte é quase divina: ressuscitar, se trata da história; criar, se trata da poesia. ${ }^{372}$

Aliás, o teatro de Victor Hugo se caracteriza por representar o passado como uma crítica do presente de forma muito similar ao drama romântico. O soberano, por exemplo, é mormente apresentado sob um ângulo negativo, como em Le roi s'amuse. A arbitrariedade em decidir sobre a vida de outros sujeitos tendo em vista interesses particulares e mesquinhos é trazida à tona como um defeito inerente ao poder. A rebeldia, nesse caso, é punida violentamente, como no caso de Lucrécia Bórgia que envenena os amigos de Genaro por tê-la ofendido.

\footnotetext{
Hugo donne donc à voir, dans le miroir déformant du passé, les contradictions du présent. Il met ainsi en place avec son drame historique un mouvement critique similaire son drame moderne. Mais alors que Dumas, prisonnier de son réalisme, se comdamne à un relatif oubli, le théatre historique de Hugo, moins directement référentiel, et plus théorique, est davantage ouvert à la réinterpretation. ${ }^{373}$
}

A representação do passado e a mistura de gêneros propostas por Victor Hugo não têm como escopo a representação do real de forma precisa, mas destacar as contradições éticas e estéticas de maneira violenta. Segundo Auerbach, somente com Stendhal e Balzac, quando se misturam o sério ao cotidiano ligando homens e história de forma orgânica, a literatura será mais realista ${ }^{374}$. No romantismo, o caráter estético e crítico, ou seja, a verdade poética é sobreposta ao realismo histórico como agente propagador da verdade.

\footnotetext{
${ }^{372}$ HUGO, Victor. Op. Cit., 2004, p. 69.

${ }^{373}$ NAUGRETTE, Florence. Op. Cit., p. 213-214.

${ }^{374}$ AUERBACH, Erich. Op. Cit., 2004, p. 419 e 431.
} 
(...) na formulação de Hugo se apresenta algo de demasiado exacerbadamente antitético: trata-se, para ele, da mistura do sublime com o grotesco. Ambos são polos estilísticos que não tomam em consideração o real. De fato, não tinha a intenção de representar a realidade dada de forma compreensiva; antes ressalta nos temas históricos ou contemporâneos, os polos estilísticos do sublime e do grotesco ou também outras contradições éticas ou estéticas, e o faz com tanto vigor que eles se entrechocam com violência; desta forma, embora surjam efeitos fortes, pois a força de expressão de Hugo é poderosa e sugestiva, são inverossímeis e, como reprodução da vida humana, falsos. ${ }^{375}$

Em "Acerca da arte trágica" Schiller associa a necessidade de a tragédia ater-se à imitação de uma ação digna de compaixão, ou seja, de reproduzir uma ação com o objetivo de comover, e, consequentemente deleitar com a verdade poética.

[...] a tragédia é poética imitação de uma ação digna de compaixão, e, por isso, oposta à imitação histórica. Seria esta última, se perseguisse um fim histórico, buscando informar de coisas acontecidas e de maneira pela qual aconteceram. Neste caso, deveria ater-se severamente à autenticidade histórica, porque só alcançaria sua finalidade graças à reprodução fiel do acontecimento real. Mas a tragédia tem um fim poético, ou seja, ela reproduz uma ação com o fim de comover e, por meio da comoção, deleitar. Ao tratar, pois, de uma dada matéria segundo esse se fim, torna-se, por isso mesmo, livre na imitação. Obtém o direito e até a obrigação de subordinar a verdade histórica às leis da arte poética e de trabalhar a matéria dada segundo as suas necessidades. ${ }^{376}$

Consoante ao exposto acima, no Prólogo de Leonor de Mendonça, Dias discute as perspectivas possíveis e a escolhas que fizera para contar o assassinato da duquesa de Bragança. Ele acredita que numa obra literária de inspiração histórica, o autor pode fazer concessões com objetivos estéticos ou críticos. Se a duquesa fosse culpada seria uma personagem mais melodramática no sentido de promover uma lição moral, mas menos condizente com o efeito trágico que o autor tinha em mente. Nesse sentido, o autor abre mão do escopo moralizante em sua peça quando escolhe fazer Leonor inocente para descrever um fato como sendo consequência de um contexto históricosocial criticando o casamento sem amor, o despotismo da nobreza e também a condição de submissão da mulher no século XVI e no século XIX: "Se a mulher não fosse

\footnotetext{
${ }^{375}$ Idem, ibidem, p. 419.

376 SCHILLER, Friedrich. Acerca da arte trágica. In: SCHILLER, Friedrich. Teoria da tragédia. São Paulo: EPU, 1991, p. 106-7.
} 
escrava, como é de fato, d. Jaime não mataria sua mulher. Houve nessa morte a fatalidade, filha da civilização que foi e ainda é."377

Claro está que a verdade do drama não pode ser confundida com a verdade factual mesmo tratando-se de um drama histórico, pois, ainda segundo Hugo, o fato não é tratado como história, mas como vida ${ }^{378}$. Nesse contexto, caberia ao historiador ordenar de forma exata fatos, datas, batalhas e todo o exterior dos acontecimentos, e ao poeta pertenceria expressar o interior e os pormenores esquecidos. A história assume a função de inspirar, de fornecer um motivo para a fantasia ${ }^{379}$.

\subsubsection{Entre a tragédia schilleriana e o drama hugoano}

Karin Volobuef em seu artigo "Friedrich Schiller e Gonçalves Dias"380 aponta algumas afinidades entre os dois dramaturgos, sobretudo através da comparação entre os dramas Wallenstein e Patkull. Em Patkull sobressairia a concepção trágica schilleriana de fatalidade: “(...) são as condições históricas e políticas da época, e a própria constituição psicológica, social e moral do personagem, que dirigem as decisões do herói e conduzem seus passos." 381 Em Patkull, o diálogo com a obra schilleriana é mais palpável, pois o herói da Livônia serve como um exemplo de abnegação em favor do coletivo, tema comum nas tragédias históricas de Schiller.

Instigado por Paikel, antigo namorado de sua noiva Namry Romhor, Patkull parte em uma missão para salvar a Livônia do jugo da Suécia. Embora, Patkull tenha jurado ao pai de Romhor que cuidaria de sua filha, ele abre mão desse compromisso individual para mais uma vez tentar defender os interesses de seu povo. Patkull é enganado por Paikel justamente porque este conhece a natureza daquele, o herói não negaria o pedido do amigo, pois tal ato discordaria do caráter humanístico do protagonista. Além disso, na cena final, Patkull chora porque ama, não porque morrerá:

\footnotetext{
${ }^{377}$ DIAS, Gonçalves. Op. Cit., p. 905. Grifos nossos.

${ }^{378}$ Nota transcrita por Michel Cambien apud HUGO, Victor. Op. Cit., p. 40-41, nota de rodapé 81.

379 "Já o chamado drama histórico romântico, abordando épocas e lugares bem mais obscuros [do que a tragédia], como a Idade Média, não hesitou em cortar as amarras que o prendiam à realidade, confiando os autores que o público se revelaria tão jejuno de informações nessas paragens dramáticas quanto eles próprios o eram. Alguns parágrafos de um livro de história, uma crônica, uma balada, até mesmo uma estampa, como vimos, tanto bastava para que se abandonasse a terra firme dos conhecimentos exatos em proveito do livre exercício ficcional.” PRADO, Décio de Almeida. Op. Cit., 1996, p. 87.

${ }^{380}$ VOLOBUEF, Karin. Op. Cit., 2005, p. 77-90.

${ }^{381}$ Idem, ibidem, p. 85.
} 
"São lágrimas nascidas de um coração que ama - nunca as derramei no travado das pelejas, nem ora me oprime e acabrunha o aspecto da morte!..." 382 Vale lembra que Schiller ajuíza a tragédia e o próprio sentimento do trágico a partir do dilema entre a liberdade moral e a necessidade natural. Patkull age de maneira sublime ao mostrar sua superioridade frente ao sensível, ou seja, em relação a sua autoconservação. A serenidade diante da morte é um efeito de sua força moral ${ }^{383}$. O homem moral pode ser fisicamente destruído, mas não derrotado espiritualmente.

Em "Acerca do patético", o poeta alemão esclarece que a arte deve representar o suprassensível, e é sobretudo a arte trágica que alcança esse objetivo, pois torna sensível a independência moral. O pathos da tragédia é o meio pelo qual o ser racional fundamenta sua liberdade manifestando, dessa forma, o que está acima da realidade sensível. Para Machado, a apresentação do suprassensível em Schiller não é metafísica, mas subjetiva. Ele a concebe como um conflito humano individual, subjetivo, entre o sofrimento físico e a vontade moral. O conflito que se constitui no sujeito que é dependente como ser sensível e livre como ser racional ${ }^{384}$.

Para Schiller, a Revolução Francesa havia mostrado que as pessoas não estavam preparadas para a liberdade, por isso, ele intentou superar esta inaptidão por meio de outra revolução, a saber, a educação estética do homem, a qual tornaria o homem apto para a liberdade. A livre relação que o homem estabelece com a arte é uma maneira de torná-lo íntegro, pois, nesse jogo, ele não joga somente com a razão, mas com o sentimento, a imaginação, a memória, desfazendo-se, dessa forma, a posição fragmentária que a sociedade moderna lhe imputou ${ }^{385}$.

Schiller delineia esse conflito artisticamente na peça Maria Stuart de 1800. Manuel Bandeira ${ }^{386}$ afirma que Schiller leu todo o material histórico existente sobre a rainha escocesa, mas fez várias concessões à verdade poética para alcançar o terror aristotélico. O clímax do drama, o encontro entre as duas rainhas, é uma invenção poética para suscitar o patético. Maria Stuart é presa sob a acusação de conspiração contra sua prima Elizabeth, rainha da Inglaterra. A história mostra, através da disputa das duas pelo trono, um embate que envolve amor, poder e liberdade. No encontro

\footnotetext{
382 DIAS, Gonçalves. Patkull. In: Op. Cit., p. 839

${ }^{383}$ SCHILLER, Friedrich. Acerca do patético in: SCHILLER, Friedrich. Op. Cit., 1991, p. 114.

${ }^{384}$ MACHADO, Roberto. Op. Cit., 2006, p. 57-58.

385 SAFRANSKI, Rüdiger. Romantismo: uma questão alemã. Trad. Rita Rios. São Paulo: Estação Liberdade, 2010, p. 41-46.

386 BANDEIRA, Manuel. In: Centro Cultural Banco do Brasil. Banco do Brasil apresenta e patrocina a peça Maria Stuart de Schiller. 2009.
} 
fictício entre as duas rainhas, a escocesa deveria apelar à prima pela absolvição. Frente a frente com Elizabeth, a Stuart, contrariamente ao que desejava fazer (pedir clemência), deixa sua natureza altiva e orgulhosa transparecer instigando ainda mais o ódio da prima contra si mesma. O trágico schilleriano em Maria Stuart, isto é, a preponderância da liberdade moral diante da dor, se apresenta tanto no fato da protagonista, por vontade própria, perder a chance de ser libertada como em admitir a sua morte no cadafalso com serenidade $^{387}$. Maria afirma sua dignidade e seu caráter sublime ${ }^{388}$, ou seja, a sua liberdade moral enquanto Elizabeth revela seu apego ao sensível.

\begin{abstract}
MARIA (em cólera, mas com nobre dignidade) - Fui culpada como mulher, como jovem. O poder perdeu-me. Mas não me escondi, porque na minha real franqueza repeli as falsas aparências. $\mathrm{O}$ que fiz de pior, o mundo sabe-o perfeitamente, e eu posso garantir que sou melhor do que a opinião que de mim tenham podido formular. Pobre de vós se alguma mão vos descobrisse, arrancando essa capa de virtude com que a vossa hipocrisia esconde a desenfreada lascívia dos vossos prazeres secretos! A virtude! Não a herdastes de vossa mãe, porque todo mundo sabe que espécie de virtude foi a que fez Ana Bolena subir ao cadafalso. ${ }^{389}$
\end{abstract}

Igualmente, a duquesa de Gonçalves Dias, escravizada pelo marido, em seus momentos finais mostra-se determinada e obstinada. Ao mesmo tempo em que pede por clemência, mostra uma natureza altiva, ofende-se porque se orgulha de sua dignidade. No momento em que tenta convencer o duque de que nada de errado fizera e salvar-se, Leonor de Mendonça tem consciência de sua condição social e da situação, por isso, por conta das aparências, ela precisa provar ser inocente. A duquesa, aliás, diz ao duque saber qual o verdadeiro sentido de seu assassinato, já que tanto Alcoforado como o padre Lopo Garcia haviam confirmado sua inocência. Ela teria atrapalhado os planos do marido, o qual gostaria de ter entrado em alguma ordem religiosa. É nesse momento que a fatalidade mencionada por Dias em seu Prólogo vem à tona, a condição de mulher naquele contexto histórico-social (que se reverbera no século XIX) e as circunstâncias selam o destino da duquesa. Novamente, a severidade do pensamento que envolve a

\footnotetext{
387 Quando não pode opor às forças do mundo físico nenhuma força física equivalente, o homem pode, pela cultura moral, 'submeter-se voluntariamente' à violência da natureza, suportar o que não pode modificar, suprimir livremente todo interesse sensível, tornando-se livre a ponto de a natureza não exercer violência sobre ele, pois, antes de atingi-lo, já se tornou sua própria ação.' O que faz dessa livre submissão não uma resignação, mas uma resistência - uma resistência da razão. MACHADO, Roberto. Op. Cit., p. 67.

${ }^{388}$ Idem, ibidem, p. 74.

${ }^{389}$ SCHILLER, Friedrich. Maria Stuart. Trad. E. P. Fonseca, Rio de Janeiro: Irmãos Pongetti, 1946.
} 
ação baseia-se na fatalidade advinda dos costumes de civilização, não na fatalidade grega ou dos Schicksalsdramas.

No entanto, na peça gonçalvina não é a "livre submissão" que se sobressai, como no caso de Maria Stuart. Leonor apega-se ao sensível e, diferentemente da escocesa, não admite pagar pelos erros cometidos, já que, pelos menos em pensamento, ela sabe não ser assim tão virtuosa. A diferença entre essas produções teatrais é que em L.M. o destaque recai sobre a questão social, o conflito entre fortes e fracos, enquanto na obra alemã, o acento incide no embate entre o plano sensível e a resistência moral. É interessante notar, porém, que em ambas as produções há uma valorização da liberdade, seja no âmbito social ou moral.

Maria Stuart condensa o conceito do trágico e da tragédia elaborados por Schiller de forma clara e, até mesmo, programática. Schiller dispensa um papel de destaque ao teatro. Para ele, na formação moral de um povo, a religião não alcança a todos, por isso, não contribui com a formação ética do homem. Já o palco exerce poderoso efeito sobre as pessoas, pois, mostra o jogo (ou o embate, no caso da tragédia) entre os instintos e a transcendência espiritual de maneira visível. Vale lembrar que, já na tragédia grega, o pensamento das pessoas medíocres, que privilegiam a autopreservação em detrimento da dignidade, é contrário às grandes figuras trágicas que assumem a luta não para sobreviverem, mas para expressarem seu valor espiritual ${ }^{390}$.

\begin{abstract}
Mesmo em comparação com as outras tragédias históricas escritas por Schiller a partir de 1795, Maria Stuart é a peça que possui relação mais direta com essa definição teórica, por isso pode ser vista como uma tentativa de realizar na arte aquilo que o autor havia concebido pelo pensamento. Todo o enredo gira em torno do jogo de forças entre a condição sensível de aprisionamento e a dignidade moral. ${ }^{391}$
\end{abstract}

Maria Stuart exprime claramente a ideia schilleriana do sublime prático quando abdica de sua vida para pagar pelo que fizera e, assim, mostrar sua superioridade moral frente ao impulso de autoconservação ${ }^{392}$. Ela aniquila a violência sofrida submetendo-se voluntariamente a ela. ${ }^{393}$

\footnotetext{
${ }^{390}$ LESKY, Albin. Op. Cit., 1976, p. 140.

${ }^{391}$ SÜSSEKIND, Pedro. In: Centro Cultural Banco do Brasil. Banco do Brasil apresenta e patrocina a peça Maria Stuart de Schiller, 2009.

392 "Sublime de modo prático é, portanto, todo objeto que nos faz notar a nossa impotência enquanto seres naturais - mas que também descobre em nós uma faculdade de resistência de tipo totalmente diferente, a qual não afasta o perigo de nossa existência física, mas (o que é infinitamente mais) dissocia nossa própria existência física de nossa personalidade. [...] Assim, o sublime não se funda de modo algum no sobrepujamento ou na suspensão de um perigo que nos ameaça, mas antes na remoção das condições
} 
Leonor de Mendonça está consciente de sua inocência e de sua superioridade moral, mas, não caminha para a morte com a mesma resignação, ou melhor, paz de espírito da Stuart. A duquesa de Bragança se desespera, por isso, Jacobbi diz que Leonor é extremamente humana e, ao mesmo tempo, angelical: "Gonçalves Dias não se preocupou com a inocência de Leonor; não quis fazer dela, um anjo; quis mostrar ao leitor (ao espectador) que toda a criatura humana é substancialmente um anjo, atirado ao inferno de contradições e equívocos da existência". ${ }^{394}$ Jacobbi tem razão ao afirmar que Leonor não é um anjo, já que a sua inclinação por Alcoforado não pode ser negada. No entanto, G. Dias preocupou-se sim com a inocência dela como atesta o Prólogo. Perante os homens, ela não cometeu nenhuma falta e é por isso que nos compadecemos do seu destino. Aliás, Arêas comenta que ela parece ser às vezes "inocentemente leviana". As suas imprudências derivam de sua falta de experiência e do desejo de ser amada, o que tornaria a sua vida menos entediante.

Outro paralelo possível com Maria Stuart baseia-se na observação de Bandeira $^{395}$ que chama a atenção para a personagem Mortimer, outra invenção de Schiller, cujo caráter exasperadamente romântico apresenta resquícios da produção stürmer do autor ${ }^{396}$. É interessante notar que na peça de Gonçalves Dias, Leonor de Mendonça, também há uma personagem similar, o jovem Alcoforado. Ele, assim como Mortimer, está ciente de que a tentativa de alcançar a mulher que ama é quase um suicídio, mas ambos correm o risco e sucumbem. Essas duas personagens condensam a aspiração romântica da unidade elementar com a infinitude ${ }^{397}$, extrapolando a conjuntura sociocultural para um plano cósmico, ou seja, a união amorosa impossível se dá num plano espiritual, por isso, amor e morte são complementares: Mortimer e Alcoforado celebram na morte a união amorosa negada no plano histórico-social.

últimas sob as quais o perigo pode se dar para nós - na medida em que o sublime nos ensina a considerar a parte sensível de nosso ser, a única submetida ao perigo, como uma coisa da natureza que é externa e não diz respeito de modo algum a nossa verdadeira pessoa, a nosso eu moral." SCHILLER, Friedrich. Do sublime. In: Op. Cit., p. 39.

${ }^{393}$ SCHILLER, Friedrich. Sobre o sublime. In: Op. Cit., p. 57.

${ }^{394}$ JACOBBI, Ruggero. Op. Cit., p. 83.

395 BANDEIRA, Manuel. In: Centro Cultural Banco do Brasil. Banco do Brasil apresenta e patrocina a peça Maria Stuart de Schiller. 2009.

396 'Boa parte da dramaturgia do 'Sturm und Drang', como já foi sugerido, gira em torno do conflito entre o herói elementar, ligado à natureza, e a sociedade civilizada em geral. Mas essa sociedade abstrata é, muitas vezes, concretizada pelos traços marcantes da época do absolutismo. E o conflito se torna em luta pela liberdade política, amorosa metafísica ou religiosa, contra as limitações impostas pelas normas convencionais, pela Igreja, pela diferença de estamentos e classes." ROSENFELD, Anatol. Op. Cit., 1991, p. 11-12.

397 Vale lembrar que essas personagens refletem também o sentimentalismo 'wertheriano', sentimento que se caracteriza pelo prazer da dor. ROSENFELD, Anatol. Op. Cit., 1991, p. 20. 
Segundo Lutz, a busca encetada pelo herói byroniano abrange o exílio do eu e a vivência da ferida kantiana decorrente da ruptura entre interioridade e exterioridade. Dessa forma, esse herói experimenta o que lhe é exterior para encontrar a si mesmo ${ }^{398}$.

\begin{abstract}
Superar as dissociações da cultura, transpor as divisões sociais, saltar as particularizações geo-históricas são, na perspectiva romântica as vias de acesso ao estado natural do homem, à sua inocência edênica. Mas a aspiração romântica, na sua busca da unidade elementar, não se detém nas projeções utópicas sobre o plano do processo sócio-cultural e mesmo antropológico. No seu desenvolvimento, ela chega às alturas da comunhão cósmica. Unir-se e fundir-se misticamente com o universo em sua infinitude é o sentimento pleno da grande síntese. [...] E o conceito de amor, e a ideia de amor, com a de morte. É a grande trindade romântica - Noite, Amor e Morte .... ${ }^{399}$
\end{abstract}

O diálogo entre Schiller e Gonçalves Dias tem sido sugerido principalmente por conta da tradução de $A$ noiva de Messina perpetrada pelo poeta brasileiro, cuja variante final não é conhecida, pois ela se perdeu no naufrágio de 1864 . A versão que se conhece é de 1862, baseada em um rascunho, a qual foi primeiramente publicada nas Obras Póstumas em 1867. Embora se trate de uma tragédia, parece oportuno tecer alguns comentários sobre essa obra e as possíveis relações com Leonor de Mendonça ${ }^{400}$.

Para Peres, é possível notar o diálogo de A. Gonçalves Dias com Friedrich Schiller tanto nas poesias de cunho dramático ("I-Juca Pirama”, "O mar", "Adeus, aos meus amigos do Maranhão") como nos próprios dramas gonçalvinos. Ao refletir sobre o diálogo do teatro gonçalvino com A Noiva de Messina, o crítico chama atenção para o tema do ciúme presente em Boabdill e Leonor de Mendonça, peça na qual também se incorpora o tópico da infância como trauma, temática que em Schiller já se adivinha pelo subtítulo - 'Os irmãos inimigos' ${ }^{401}$. Contudo, é preciso atentar que G. Dias assevera no Prólogo de Leonor de Mendonça que d. Jaime não sente ciúmes. Ele é cioso de sua posição, seu nome. Não é por despeito que ele manda matar Alcoforado, mas, sobretudo, pelo orgulho ferido diante da audácia de ambos os apaixonados desobedecerem-lhe, desafiá-lo.

Como bem observou o estudioso, as duas obras, A Noiva de Messina e Leonor de Mendonça, se diferenciam no que concerne à questão da fatalidade. Na obra

\footnotetext{
398 LUTZ, Deborah. The dangerous lover: Gothic villains, Byronism, and the nineteenth century seduction narrative. Columbus: The Ohio State University Press, 2006, p. X.

${ }^{399}$ ROSENFELD, Anatol; GUINSBURG, J. Romantismo e Classicismo. In: GUINSBURG, J. (Org.). Op. Cit., p. 272.

400 PERES, Marcos Flamínio. In: SCHILLER, Friedrich. A noiva de Messina, ou, Os irmãos inimigos: tragédia com coros. Trad. Antônio Gonçalves Dias. São Paulo: Cosac \& Naify, 2004.

${ }^{401}$ Idem, ibidem.
} 
schilleriana o amor, que é incestuoso, reverbera a irreversibilidade do destino que esmaga as personagens. Já em L.M., os acontecimentos originam-se das escolhas feitas pelos caracteres. Embora coagidos pelos "costumes", eles têm livre-arbítrio. Essa diferença se fundamenta na tentativa que o autor alemão faz de atualizar a tragédia antiga inclusive com a reintrodução do coro. $\mathrm{O}$ escopo da experiência schilleriana era minimizar o ilusionismo teatral que, segundo o dramaturgo alemão, minora a capacidade de reflexão do espectador tolhendo-lhe a liberdade ${ }^{402}$. Schiller, aliás, em desconformidade com "os chamados gêneros médios" defende a metrificação do texto e a permanência da inclusão de partes líricas nas peças. Assim, pode-se conjecturar que enquanto Gonçalves Dias se esforça para produzir uma obra de gênero médio, o autor de Os Bandoleiros se volta para a tragédia em que o destino incontornável, diferentemente da proposta gonçalvina, é decorrente de uma maldição. É interessante notar que Friedrich Schiller foi bastante criticado por inserir um conteúdo romântico numa forma antiga ${ }^{403}$.

Os objetivos dos autores também são distintos. Dias em conformidade com o drama que vinha sendo produzido na França desde 1830 critica as desigualdades sociais por meio de uma estrutura que, por si só, já questionava os padrões antigos. Schiller retrocedendo à tragédia com coros visava fazer com que a arte dramática não incidisse apenas sobre a sensibilidade dos espectadores preservando-lhes a capacidade de reflexão e julgamento. Portanto, enquanto aquele discute com mais ênfase a questão da liberdade social, este busca aprimorar a liberdade espiritual do homem.

\footnotetext{
402 "Da mesma maneira que traz vida à linguagem, o coro traz tranquilidade à ação - mas a bela e elevada tranquilidade que deve ser o caráter de uma obra de arte nobre. Pois a mnte do espectador deve preservar sua liberdade mesmo na paixão mais violenta, não deve ser presa das impressões, mas se separar semre clara e alegremente das emoções que sofre. O que o juízo comum costuma censurar no coro, que ele faz cessar a ilusão, que interrompe o poder dos afetos, é o que o torna altamente recomendável, pois é exatamente esse poder cego dos afetos que o verdadeiro artista evita, é essa ilusão que ele desdenha provocar. Se os golpes com que a tragédia nos atinge o coração se seguissem sem interrupção, a paixão venceria a atividade. Nós nos misturaríamos à matéria e não mais pairaríamos sobre ela. Porque mantém as partes separadas e entra com sua reflexão tranquilizadora no meio das paixões, o coro nos devolve a liberdade, que iria se perder na tempestade dos afetos," SCHILLER, Friedrich apud SUZUKI, Márcio. "A 'guerra ao naturalismo: a propósito do coro na Noiva de Messina". In: SCHILLER, Friedrich. A noiva de Messina, ou, Os irmãos inimigos: tragédia com coros. Trad. Antônio Gonçalves Dias. São Paulo: Cosac \& Naify, 2004, p. 218.

${ }^{403}$ SCHLEGEL, August Wilhelm. $37^{\mathrm{a}}$ preleção sobre arte e literature dramáticas. In: SCHILLER, Friedrich. A noiva de Messina, ou, Os irmãos inimigos: tragédia com coros. Trad. Antônio Gonçalves Dias. São Paulo: Cosac \& Naify, 2004, p. 197.
} 
Em suma, como pontuou Volobuef ${ }^{404}$, o diálogo com Friedrich Schiller pode ser discernido na maneira como Dias aborda os conflitos históricos, na preferência pelo uso de uma linguagem elevada ${ }^{405}$ e na aderência à estrutura clássica.

Como o Prólogo da peça nos deixa atinar, a obra gonçalvina igualmente dialoga com os dramas de Victor Hugo. Dessa forma, propõe-se refletir sobre algumas posições hugoanas as contrapondo às escolhas estéticas perfilhadas por Gonçalves Dias. No prólogo de Ruy Blás, por exemplo, Victor Hugo esclarece por que razão a significação histórica é importante para essa peça. Ele esclarece que Ruy Blás se relaciona com Hernani, pois ambas as obras versam sobre a história espanhola ressaltando a relação entre a realeza e a nobreza em períodos distintos. Por outro lado, o autor francês adverte no mesmo prefácio que o sentido histórico do drama não o explica, apenas aponta um de seus aspectos, pois que: "A verdade absoluta só está no conjunto da obra" 406 . Ruy Blás, segundo o seu criador, pode ser compreendido do ponto de vista filosófico, humano ou dramático.

É preciso atentar também para outra peculiaridade do teatro histórico de Victor Hugo, seus enredos sempre fazem um paralelo com a França coetânea fragilizando a classificação que separa o drama histórico do drama romântico. Conforme já foi comentado neste trabalho, Gonçalves Dias também relaciona o fato histórico abordado ao período da escrita. Assim, embora aqui se faça a distinção entre os dois gêneros, drama histórico e drama romântico, levando em conta a tradição crítica, considera-se que a diferença entre ambos seja muito tênue inclusive em relação aos temas, e, principalmente no caso de obras mais complexas, como é o caso do teatro hugoano e de Leonor de Mendonça. É interessante notar que nem Hugo nem Dias classificam seus dramas como históricos, eles definem seus trabalhos como sendo somente dramas no frontispício das peças.

Em suma, os dramas hugoanos e gonçalvinos têm sido considerados históricos pela crítica literária, e a faceta histórica realmente assume parcela significativa desses escritos, porém na medida em que a exploração dessa temática vincula-se à estética

${ }^{404}$ VOLOBUEF, Karin. Op. Cit., 2005, p.83.

${ }^{405}$ A propósito, Peres denota que "a versão de A noiva de Messina que chegou até nós concentra o melhor da diç̧ão poética de Gonçalves Dias - uma linguagem plena ao mesmo tempo de candura e vigor expressivo. Exemplo disso são os ecos camonianos que o poeta naturaliza tão bem, o domínio notável das aliterações ('O sonho é sonho sempre, e os signos mentem'), a capacidade essencialmente dramática de conduzir a tensão, que se avoluma até explodir em um único verso ('Calados marcham vingativos deuses'), ou ainda o uso preciso da apostrofação, que anuncia o desenlace trágico: 'Deuses, que esta casa protegestes, /Cedei o passo às fúrias vingadores!'.” PERES, Marcos Flamínio. Op. Cit., 2004.

${ }^{406}$ HUGO, Victor. Prefácio. Ruy Blás. In: Op. Cit., 1960, p.364. 
romântica, assim como outros elementos não menos importantes destacados a seguir. Dito de outra maneira, importa mais destacar a concepção de drama aventada por Victor Hugo e adotada pelo dramaturgo brasileiro do que salientar apenas um de seus predicados, o historicismo.

Nesse sentido, basta lembrar que a partir de 1830, as obras dramáticas de Hugo passam a privilegiar o tema das injustiças sociais como as advindas das diferenças entre os privilégios da nobreza e a desqualificação dos nascidos nas classes humildes. Em Angelo, por exemplo, além da questão da diferença social, ele agrega a da injustiça entre gêneros, propostas retomadas por Dias em Leonor de Mendonça. "Para ambos [Hugo e Gonçalves Dias], o olhar penetrante do dramaturgo deve rasgar a cortina das aparências e das convenções sociais." ${ }^{307}$ Ruy Blás, o lacaio que ama uma rainha, não está muito distante de Alcoforado, de Chatterton ou de Antony.

Aliás, a ênfase na questão da desigualdade e a aproximação entre personagens injustiçadas não é explorada apenas no teatro de Hugo, em Notre Dame de Paris, por exemplo, Quasímodo e Esmeralda, apesar das diferenças, são cúmplices em suas misérias e por isso se ajudam e se compreendem. O tema do amor impossível não deve ser visto apenas da perspectiva da intriga, mas também pelo prisma estético, pois a disparidade, os contrastes e as oposições são formas de representação do grotesco hugoano ${ }^{408}$.

Desse modo também se opera a oposição-aproximação entre Ruy Blás e a Rainha, Rodolfo e Tisbe/Catarina (Angelo), Alcoforado e Leonor de Mendonça. Vale lembrar que entre essas personagens desafortunadas, as quais de alguma forma se tornam compartes, sempre se interpõe um caracter que opera o grotesco, já que representa o terror da crueldade e da morte ${ }^{409}$ : Dom Salusto, Angelo e d. Jaime. Por outro lado, como bem coloca Volobuef, "o grotesco nasce da justaposição de elementos opostos que causam estímulos opostos...”, assim, a personagem grotesca (a personagem que no teatro antigo seria cômica) é quem, na verdade, garante a beleza, a sublimidade. Nesse sentido, Ruy Blás, o lacaio, Tisbe, a cortesã e Alcoforado, o jovem cavaleiro são moralmente superiores aos caracteres que seriam, na tragédia clássica, da esfera do

\footnotetext{
${ }^{407}$ GIRON, Luís Antônio. Op. Cit., p. 186.

${ }^{408}$ VOLOBUEF, Karin. Victor Hugo e o grotesco em Notre-Dame de Paris. Lettres Françaises, n. 5, 2003, p. 26-30.

${ }^{409}$ CECCHINI, Gisele Molon. Lucrécia Bórgia: um drama no oceano de Victor Hugo. v. 1. Porto Alegre, 2009, Dissertação de Mestrado. PUC do Rio Grande do Sul, 2009, p. 112.
} 
sublime, pois: "A verdade contém a moralidade, o grande contém o belo" 410 . É com essa acepção que Hugo (e também G. Dias) constrói o drama, conglobando e misturando os elementos da comédia e da tragédia.

Tisbe destina-se a satisfazer Ângelo. Afinal ela é 'filha dos prazeres' e sua função é diverti-lo. A personagem grotesca torna-se trágica no momento em que sacrifica a si própria para salvar a quem ama. Rodolfo. (...) O próprio Ângelo interpreta o grotesco tirano do terror e da morte. Ao trio grotesco, opõem-se os amantes clássicos. Eis as misturas no drama do autor. Como queria Hugo, ele mostra um drama suntuoso e doméstico... ${ }^{411}$

Analisar a forma como o grotesco atua na obra de Victor Hugo colabora para a compreensão do gênero drama elaborada pelo autor francês. A proposta de Hugo não é abordada por Dias apenas com a inserção da cena na casa de Alcoforado, trecho em que a mistura de gêneros fica mais explícita. O jogo de oposições entre as personagens, conforme se considerou acima, também contribui para compor um gênero que propõe incorporar elementos da tragédia e da comédia. Mesmo quando as personagens nobres agem em desconformidade aos padrões de sua classe, Hugo está pondo em prática a sua proposta para o drama. Assim, a cada vez que a Rainha de Carlos II fere a etiqueta (Ruy Blás), como aponta a todo o momento a figura da duquesa de Albuquerque, o elemento grotesco (cômico) interpõe-se à personagem sublime (trágica), não de maneira a provocar o riso, mas compadecimento e identificação ${ }^{412}$. De forma menos explícita, Gonçalves Dias emprega o mesmo subterfúgio, fazendo de sua duquesa não apenas uma nobre, mas uma mulher que, como todas as mulheres, se caracteriza por ser infeliz e generosa, conforme propusera Hugo no prefácio de Angelo ao retratar Catarina e Tisbe, a mulher dentro e fora da sociedade:

Colocar em presença, numa ação inteiramente resultante do coração, duas graves e dolorosas figuras, a mulher na sociedade, a mulher fora da sociedade; isto é, em dois tipos vivos, todas as mulheres, toda a mulher.

\footnotetext{
${ }^{410}$ HUGO, Victor. Prefácio a Maria Tudor. In: Op. Cit., 1960, p. 10.

${ }^{411}$ Idem, ibidem.

412 "A RAINHA, vivamente.

Como! Mal as [lavadeiras que passam a cantar do outro lado do muro] estamos ouvindo. Pobres mulheres! Quero que passem em paz, senhora (A Cacilda, mostrando uma persiana ao fundo). Por aqui o arvoredo é menos espesso, esta janela dá para a campina; vem, tratemos de as ver. (Dirige-se para a janela com Cacilda).

A DUQUESA, levantando-se com uma reverência. Uma rainha da Espanha não deve olhar pela janela."
} 
Mostrar estas duas mulheres que resumem tudo nela, generosas frequentemente, infelizes sempre. ${ }^{413}$

Essa colocação vincula-se à proposta exposta também na introdução de Angelo de que o drama não deve ser inteiramente real e nem totalmente burguês para que a assimilação da ideia apresentada não seja prejudicada por ser demasiadamente grande ou mesquinha, imprimindo assim o grande e o verdadeiro ao drama. Vale repetir que essa questão proposta por Hugo é retomada por Dias no prólogo de L.M, por isso é preciso elucidar que a ideia do grande e do pequeno, do real e do doméstico recupera o princípio do sublime e do grotesco hugoano, isto é, do próprio drama. Os caracteres não podem ser apresentados apenas como reis ou burgueses, ou seja, somente abarcando aspectos do trágico ou do cômico, mas de ambos: as rainhas e as duquesas são cômicas e trágicas, assim como os lacaios e os jovens cavaleiros também o são porque expõem toda a sublimidade de seus sentimentos e toda a "comicidade" do seu cotidiano. As personagens do domínio da tragédia expõem os mesmos sentimentos que os do âmbito da comédia e vice-versa.

No Prefácio à Maria Tudor, Hugo desenvolve a ideia dando como exemplo a personagem shakespeariana Hamlet, a qual consegue conglobar o grande e o verdadeiro porque não representa apenas um homem, mas todos ${ }^{414}$ : "Hamlet, por exemplo, é tão verdadeiro quanto qualquer um de nós, e maior. É que Hamlet não é nem vós, nem eu, nem outrem, é todos nós. É colossal e, entretanto, real. Hamlet não é um homem, é o homem."415 Um exemplo claro dessa mistura entre alto e baixo para que se efetive o grande e verdadeiro se dá na fala de Maria Tudor no drama homônimo, trabalho do autor em que se configura pela primeira vez o foco nas disparidades sociais. Aliás, as falas da rainha causaram surpresa ao público devido à franqueza, expondo seus desejos como uma mulher comum, e registro prosaico ${ }^{416}$ :

\footnotetext{
${ }^{413}$ HUGO, Victor. Prefácio a Angelo. In: Op. Cit., 1960, p. 155.

${ }^{414}$ Han sintetiza a imagem que os românticos construíram sobre Hamlet, essa representação está refletida no texto de Hugo:"The Romantics put Hamlet within a hermetic unit by reading him as a reserved, thoughtful, and melancholy character, whereas some other critics of different ages and countries take him to the public arena for this social political, and cultural purposes. Foakers's paper focused on how the Romantic Hamlet, privatized as a representative of everyman, had an effect on the various reconstructions of the character of Hamlet in later ages. The Romantic image of Hamlet, as an embodied emblem of the anguish of isolation, became a dominant value amongst nineteenth century intellectuals and artists." HAN, Younglim. Romantic Shakespeare: from stage to page. New Jersey: Fairleigh Dickinson Univ. Press, 2001, p. 20-21.

${ }^{415}$ HUGO, Victor. Prefácio a Maria Tudor. In: Op. Cit., 1960, p. 10.

416 "Despite Mary's striking use of hypotyposis, or visually powerful, vivid description, it is quite possible that Hugo's audience found unlikely a queen's expression of such naked emotion before her assembled court. [...] Mary Tudor entertains no such desire to keep up appearances, and Hugo's
} 


\begin{abstract}
A RAINHA.
Muito bem, e não compreendeis o que isto significa, senhor? Será preciso dizer-vos tudo, tim-tim por tim-tim, e terá uma mulher de colocar a nu o coração perante vós, só por que a rainha, a infeliz, e por que aqui representais o rei da Espanha, meu futuro marido? Meu Deus, senhor, não sabíeis disto, mas numa mulher o coração tem o seu pudor como o tem o corpo. Pois muito bem, visto que desejais saber, visto que fazeis de conta que nada compreendeis, sim, eu adio todos os dias a execução de Fabiani, empurrandoa para dia seguinte, porque todas as manhãs me faltam as forças à ideia de que o sino da Torre de Londres vai soar pela morte deste homem, porque me sinto desfalecer ao pensamento de que cheguem a aguçar um machado para este homem, porque me sinto morrer só de pensar que se vai fechar um caixão sobre este homem, porque sou mulher, porque sou fraca, porque sou doida, porque amo este homem, por Deus! - Tendes suficientes razões agora? Estais satisfeito? Compreendeis? Oh! Acharei os meios de me vingar de vós um dia por tudo o que me fazeis dizer hoje, ficai sabendo disso! (17 $^{2}$ 103 .
\end{abstract}

Note-se como a fala de Maria Tudor retoma o que foi exposto no prólogo hugoano revelando o sentimento exacerbado de uma mulher que ama e sofre, não o de uma rainha. Ao longo do discurso, a repetição da palavra "mulher" contraposta ao termo "homem" (Fabiani) reafirma essa sobreposição. Além disso, a linguagem crua, mas patética, construída com o abundante uso de interrogações e exclamações, contribui para dar o efeito buscado pelo dramaturgo. Outra observação importante é a autodefinição de Maria como sendo fraca, essa afirmativa também deve ser entendida com base nos prefácios de Hugo, ou seja, a fraqueza não é inerente à rainha, mas à mulher como ser e como elemento social, pois a obra teatral expressa assuntos filosóficos, humanos e dramáticos. Gonçalves Dias atualiza a mesma proposta sobre a condição da mulher em sua Leonor, como evidencia o trecho a seguir:

\begin{abstract}
A DUQUESA (de joelhos) - Perdão, senhor, perdão. Não era isso o que eu vos quisera dizer; mas sei eu porventura o que digo?... Estou quase louca, não penso, não meço as minhas palavras. Perdoai-me!... Eu amo a vida, $\mathrm{Sr}$ Duque; por que vos hei de eu mentir?... Sou uma mulher fraca e sem forças; choro porque a amo e porque me dói perdê-la. Sou eu algum homem para ter coragem?... Amo a vida, amo tudo o que me cerca, amo tudo o que me era indiferente... sou nova e não posso me resignar... sou inocente e não devo morrer. Perdoai-me! $[\ldots]^{418}$
\end{abstract}

A posição de Leonor descrita na rubrica (de joelhos) simboliza a posição humana e social que a mulher ocupa, a qual não corresponde, por outro lado, com a

bourgeois audience seems to have found her frankness too hard to take." HALSALL, Albert W. Victor Hugo and the Romantic Drama. University of Toronto, 1998, p. 140.

${ }^{417}$ HUGO, Victor. Maria Tudor. In: Op. Cit., 1960, p. 103.

${ }^{418}$ DIAS, Gonçalves. Op. Cit., p. 964. 
condição nobiliárquica, provocando no drama, como proposto por Hugo, o efeito do grande e do verdadeiro. No entanto, a linguagem utilizada pela duquesa de Gonçalves Dias, bem como a de todas as suas personagens, é sempre bem cuidada ou menos "crua" do que a empregada por Hugo, o que faz com que nesse aspecto a obra brasileira se aproxime mais das obras neoclássicas (e da obra schilleriana) e se distancie da proposta do autor de Cromwell.

\footnotetext{
La sacro-sainte 'bienséance', en imposant à chaque personnage, défini à la fois par son caractère et son rang, le langage qui lui convient, et une force conservatrice, défendant contre l'érosion contestataire l'équivalence entre la sratification sociale e la stratification du langage. Donner aux rois et aux nobles um langage bas, trivial, est donc um acte politique tendant à aplanir les differences, et à priver des personnages qui sont au sommet de la pyramide sociale de ce qui les distingue, de leur dignité en somme. ${ }^{419}$
}

Outra questão que parece destoar de Hugo é que a fraqueza de Maria Tudor decorre (também) da paixão que sente por Fabiani enquanto Leonor expressa sua impossibilidade de ter coragem quando está prestes a perder a vida. Todavia, se compararmos o drama gonçalvino com Angelo, nota-se que o autor brasileiro aqui igualmente dialoga com o teatro de Hugo. Catarina, esposa do podestá Angelo, também é ameaçada de morte pelo marido que interceptara uma carta do "amante" dela. A reação da personagem hugoana diante da iminência de morte evoca o comportamento da Leonor gonçalvina. A propósito, o próprio delineamento das personagens é muito similar, ambas sentem-se prisioneiras de um marido dominador e violento, são condenadas por uma traição que efetivamente não cometeram e demonstram grande apego à vida. Comparando-se as falas de Catarina com a de Leonor citada anteriormente, é possível estabelecer um paralelo entre as duas personagens com base na reciprocidade de conteúdo dos discursos, bem como no tom patético que a conjuntura exige. As questões da impossibilidade de ter ânimo diante da situação, a consciência da inocência e o amor à vida reproduzidos por Leonor ecoam os sentimentos expressos pela personagem de Hugo:

CATARINA.

[...] Serei obrigada a ter coragem? Não tenho vergonha em confessar que sou uma mulher bem fraca e que só pode despertar piedade. Choro porque a morte me faz medo. Não é culpa minha. ${ }^{420}$

${ }^{419}$ GAUDON, Jean. Introduction. In: HUGO, Victor. Hernani. Edited by John J. Janc. University Press of America, 2014.

${ }^{420}$ HUGO, Victor. Angelo. In: Op. cit., 1960, p. 262. 


\section{CATARINA}

Morrer imediatamente, assim! Mas eu não fiz nada que merecesse a morte, bem o sei! Senhor, senhor, ainda um dia! Não, nem um dia, sinto que não teria mais coragem amanhã do que hoje. Mas a vida! Deixai-me a vida! Um claustro! Assim, dizei-me, é verdadeiramente impossível que me deixeis a vida $?^{421}$

Há outra fala da duquesa de Bragança que é bastante sintomática no que tange o evidenciamento da relação da obra dramática gonçalvina com a de Victor Hugo. O trecho destaca a injustiça sofrida por Leonor refletindo a opressão a que a mulher estava socialmente subjugada. Dito de outra forma, o duque e o podestá hugoano agem estribados por um direito de vingança dado aos homens no caso de adultério e que lhes proporciona um poder abusivo e condiciona as mulheres a uma posição inferior (daí serem fracas) e de suscetibilidade à tirania.

A citação de Hugo a seguir é bastante longa, mas essa extensão permite-nos notar como a composição dos autores se diferencia apesar das semelhanças no que concerne ao conteúdo. O escritor francês é mais prolixo e explícito evidenciando a intenção das personagens e trabalhando o grotesco também na linguagem, enquanto o registro de Dias é mais sucinto. Ao passo que Catarina ofende Angelo de forma direta e prosaica chamando-o de infame e covarde, Leonor apenas insinua o mesmo ao dizer que o duque utilizou de subterfúgios para se livrar dela e assim satisfazer seus desejos. Claro está que as palavras da duquesa são bastante francas e denunciam, tanto como faz Catarina, as condições de interesse que fundamentam o casamento deles e a infâmia e covardia do duque para desfazer-se do "negócio". De qualquer forma, Leonor não expõe sua insatisfação de forma tão manifesta como a personagem de Hugo, mas o leitor/espectador conhece que a duquesa está descontente com o casamento. Vale lembrar que em outra fala, Leonor, assim como faz Catarina, reclama da feição sombria do marido e comenta sobre a obsessão dele em relação à desgraça que sucedera ao pai e ao irmão. Pode-se dizer que ao ler os dramas de Victor Hugo, o que parecia vago ou é apenas intuído no texto gonçalvino fica mais claro, nesse caso, o descontentamento de Leonor fica mais plausível ao lermos Angelo.

\footnotetext{
A DUQUESA - Sr. Duque, vós sois poderoso e escusais de subterfúgios contra mim. Ninguém vos pedirá contas da minha morte, senhor, e dizei-o francamente que ninguém nos escuta: "Morrerás porque assim o quero!” É uma razão que todos compreendem, a razão do mais forte, se não é a do mais nobre. Contra a vossa vontade me oferecestes mão de esposo, e tendes vivido
}

${ }^{421}$ Idem, ibidem, p. 250. 
sempre constrangido considerando-me como um estorvo para a vossa vocação, porque premeditáveis ser frade ou coisa semelhante. Bem oportunamente vos sorri este ensejo para de mim vos desfazerdes. Aproveitai-vos dele, e agradecei ao azar sem ostentardes de justiceiro. Não me faleis em justiça humana, senhor, porque eu me poderei lembrar que vosso pai foi humanamente justiçado! ${ }^{422}$

CATARINA.

Falemos simplesmente. Não se trata de questão dos Bragadini. Sois um infame! Assim é que vindes friamente à minha presença com o veneno na mão! Culpada? Não, eu não sou culpada de coisa alguma. Pelo menos da maneira que estais supondo. Mas não descerei a me justificar. E além do mais, visto que vós mentis sempre, não iríeis acreditar em mim. Na realidade, eu vos desprezo. Vós me desposastes por causa do meu dinheiro, porque eu era rica, porque minha família tem um direito sobre a água das cisternas de Veneza. Dissestes: isto me trará cem mil ducados por ano, tomemos esta rapariga. E que vida tive eu convosco, nestes cinco anos? Dizei! Vós não me amais. Sois, entretanto, ciumento. Mantendes-me numa prisão. Quanto a vós, tendes amantes, isto vos é permitido. Tudo é permitido aos homens. Sempre duro, sempre sombrio comigo. Jamais uma boa palavra. Falando sem cessar de vossos pais, dos doges que foram da vossa família. Humilhando-me na minha. Se acreditais que é isso que faz uma mulher feliz! Oh! É preciso ter sofrido o que eu sofri para saber o que é que sai das mulheres. Pois seja, senhor. Amei um homem antes de vos conhecer, um homem que amo até agora. Vós me matais por causa disso. Se tendes direito a fazer uma coisa dessas é preciso convir que atravessamos uma época bem horrível! Ah! Estais feliz, não é assim? Porque tendes uma carta, um farrapo de papel, um pretexto! Pois bem. Vós me julgais, me condenais, e me executais. Na sombra. Em segredo. Pelo veneno. Tendes a força a vosso lado. - É covarde! $[\ldots]^{423}$

Vale observar que embora haja muitas semelhanças com os dramas de Hugo, Leonor de Mendonça não se confunde com um simples arremedo e as diferenças operadas pelo dramaturgo brasileiro garantem a qualidade e a originalidade de sua produção. Conforme as observações acima, é possível sugerir que Dias estava a par de grande parte da produção do mestre francês e, imbuído dos postulados do drama hugoano, criou a sua obra prima. No caso da relação entre Angelo e L.M., consoante ao que foi assinalado anteriormente, alguns aspectos do enredo são análogos, como o suposto adultério descoberto por meio de uma carta bem como o tema do casamento sem amor. No entanto, a composição de Victor Hugo é mais complexa abrangendo um número maior de personagens secundárias, subenredos, reconhecimentos, envenenamentos e outros elementos que a aproximam do melodrama. Nesse sentido, contribuem o desenlace feliz para os amantes Catarina e Rodolfo, e a morte da cortesã Tisbe.

${ }^{422}$ DIAS, Gonçalves. Op. Cit., p. 964.

${ }^{423}$ HUGO, Victor. Angelo. In: Op. cit., 1960, p. 259. 
Other devices of plot and language necessary to provoke the drama's didactic conclusion include some of the tools of melodrama, particularly keys, secret doors and passages, poison and counter-poison, and a gallery of rogues, as cretinous as they are deadly. ${ }^{424}$

É preciso observar que Victor Hugo compreende o entretenimento como elemento inerente ao drama, pois além de divertir a multidão, colabora para desenvolver a própria obra tornando-a mais humana e, assim mais persuasiva.

\begin{abstract}
Para todo homem que fixa um olhar sério às três espécies de espectadores de que acabamos de falar [as mulheres, os pensadores e a multidão], é evidente que têm elas todas as três razões. As mulheres têm motivos para querer ser comovidas, os pensadores razão para querer ser comovidas, os pensadores razão para querer ser ensinados, a multidão não está errada ao querer ser divertida. Dessa evidência se deduz a lei do drama. Com efeito, para além dessa barreira de fogo que se chama a rampa do palco, e que separa o mundo ideal do mundo real, criar e fazer viver, nas condições combinadas da arte e da natureza, isto é, dos carcacteres, e nós o repetimos, de homens; nesses homens, nesses caracteres, jogar paixões que desenvolvem estas e modificam aqueles, e enfim do choque desses caracteres e dessas paixões, com as grandes leis providenciais, fazer sair a vida humana... ${ }^{425}$
\end{abstract}

Já a concisão de cunho clássico observada na ação dramática da obra gonçalvina, a qual colabora para o delineamento das personagens e o avultamento do pathos, bem como para o desfecho trágico, a dissociam dos clichês do melodrama salvaguardando a sua modernidade. Em relação aos caracteres, é conveniente observar, por exemplo, a diferença entre Angelo e d. Jaime. Ao passo que o podestá despreza e maltrata a mulher distraindo-se com amantes, o duque trata Leonor com civilidade e a suas descomposturas devem-se a traumas de infância e ao desejo de ser religioso, além da sua posição social. Esses pequenos detalhes fazem com que a personagem de Gonçalves Dias torne-se menos plana, já que também sofre por sua condição, diferentemente de Angelo.

Vale a pena mencionar aqui os comentários que Arêas faz acerca de d. Jaime, o qual, segundo ela, tem sido estereotipado pela crítica, ou melhor, compreendido apenas com base no violento assassinato que cometeu. Conforme assinalado no presente estudo, o perfil do duque delineado por meio de subsídios narrativos dentro da peça, bem como suas ações e falas, não se confunde com o do vilão melodramático, embora deva muito a esse modelo. A crítica tem razão em afirmar que a personagem do duque

\footnotetext{
${ }^{424}$ HALSALL, Albert W. Op. Cit., p. 147.

${ }^{425}$ HUGO, Victor. Prefácio a Ruy Blás. In: Op. Cit., p. 357.
} 
ainda não foi explorada de forma satisfatória, justamente por não ser plana e agir coagida pelas circunstâncias sociais assim como Leonor.

No entanto, a sugestão de que d. Jaime teria interesse na duquesa e tenta se aproximar dela, conquanto de maneira desajeitada, não parece plausível. A observação da estudiosa serve como argumento para a ideia de que é a duquesa quem refuta o marido e se recusa a amá-lo. Seria preciso relevar várias falas das personagens e a própria proposta do autor ${ }^{426}$ para que pudéssemos crer nos sentimentos do duque e descolar a sua figura da violência cometida. Como contra-argumento sobre a possibilidade de o duque estimar Leonor, pode-se relembrar que Dias, no Prólogo, ao comparar d. Jaime com Otelo, pontua que o nobre não ama Leonor. A lisura com que o marido trata a esposa, consoante comentários anteriores, deve-se a convenções e não a sentimentos. A duquesa explica que estaria disposta a amar o consorte, mas é ele que assim não o quer, porque para o duque ela representa a constante lembrança de que o seu desejo de se tornar religioso foi frustrado. Arêas menciona como argumento a fala de d. Jaime a Leonor esclarecendo que ninguém poderia obrigá-lo a se casar com ela. Todavia, numa peça que se pauta na ideia de "fatalidade cá da terra", o título nobiliárquico, o costume, e as relações de poder que um consórcio implicava não podem ser desprezados. A pergunta de d. Jaime "E quem me obrigaria?" reflete o orgulho e a prepotência de quem hierarquicamente estava abaixo apenas do rei, mas, por outro lado, devia ao monarca o perdão dado à sua família. A Cena VIII do I Ato em que os duques conversam sobre o favor devido ao jovem cavaleiro por ele ter salvado Leonor do javali é bastante sintomática no que concerne a relação dos caracteres ser pautada pela consciência da estratificação social. Nesse diálogo, o casal de nobres interage com urbanidade e distância, e fala de Alcoforado como se tratasse de um bem. Outrossim, sobre o trecho, é conveniente lembrar que G. Dias adverte no Prólogo que mesmo quando d. Jaime pede, ainda manda.

O duque é severo porque é insensível; o velho Alcoforado é também severo, mas ama. O primeiro é severo como nobre e como senhor; quando ele fala, manda, quando ele pede, manda ainda; é-lhe precisa a obediência, porque não sabe pedir; ele a exige, porque não sabe mandar. Como, porém, é ao mesmo

\footnotetext{
${ }^{426}$ Vale mencionar que a análise de Arêas considera o que G. Dias propõe no Prólogo para a personagem em questão: "Em suma, o que desejo explicitar é que, nesta peça 'de virtualidades', nem tudo ainda foi explorado, principalmente quanto a D. Jaime, imobilizado no juízo dos leitores pela brutalidade do castigo imposto à mulher e pela definição que dele nos dá o próprio poeta em seu 'Prólogo': apesar de considerar que, como Leonor, d. Jaime 'só tem defeitos e não vícios, ele também afirma que 'o Duque é severo porque insensível” ARÊAS, Vilma. Op. Cit., 2013, p. 239.
} 
tempo urbano e cortesão, a duquesa tem de se mostrar livre e senhora de sua vontade, o que torna incomportável a escravidão. ${ }^{427}$

Mais uma vez, d. Jaime é movido pelos sentimentos de pertencimento à nobreza, orgulho e vingança, os quais o tornam desconfiado e violento:

\begin{abstract}
No primeiro plano, o duque, a duquesa e Alcoforado. Alcoforado dedicado e extremoso, a duquesa agradecida e imprudente, e entre ambos o duque sombrio e desconfiado. Entre a duquesa Alcoforado correr uma cadeia de benevolência e serviços, de extremos e gratidão, fazer cair o duque sobre ambos despedaçando a cadeia com a sua força, arrojando a cabeça do homem aos pés de seus lacaios, e empolgando a mulher como uma presa para nela ceivar sua vingança. ${ }^{428}$
\end{abstract}

Além disso, Leonor de Mendonça dialoga com outros dramas em que pesa a questão do despotismo da nobreza e dos homens em relação às mulheres. Desse modo, pode-se inferir que há no drama a tentativa de discutir esse assunto. No entanto, há de se convir que Dias não delineia suas personagens de forma determinante, elas são por vezes ambíguas configurando nuances de perfil que enriquecem a obra. E como o próprio autor ressalva, a intenção em relação à obra nem sempre se concretiza.

Gonçalves Dias parece ter se valido de diversas fontes para elaborar a estrutura do enredo de Leonor de Medonça independentemente da questão do gênero. O folhetim citado a seguir, escrito pelo autor em 30 de setembro de 1849 para o Correio Mercantil, permite-nos pensar como a obra em questão se vale de um entrecho comum à arte dramática, o qual já havia sido explorado na tragédia, no drama, na comédia e na ópera. Além disso, o trecho do artigo gonçalvino desvela algumas nuances que o conflito entre a esposa inocente e o marido hipoteticamente traído pode assumir, como prescindir de uma dicotomia entre as personagens de forma a gerar um viés maniqueísta e a impossibilidade de defesa para a mulher. É curioso que o comentário procede de uma crítica da ópera $A$ Sonâmbula de Bellini, a qual versa sobre as questões expostas por Dias e também sobre a repressão do desejo feminino. Amina, a protagonista, é cortejada pelo conde Rodolfo mesmo estando comprometida com o agricultor Elvino, mas não trai o noivo, apesar das aparências: a moça é encontrada no quarto do nobre após um ataque de sonambulismo.

\footnotetext{
${ }^{427}$ DIAS, Gonçalves. Prólogo a Leonor de Mendonça. In: Op Cit., p. 906.

${ }^{428}$ Idem, ibidem.
} 
Uma esposa que se vê injustamente acusada, um marido que se crê atraiçoado, um concurso de circunstâncias combinadas à maneira dos romances para agravar a acusação, tornando mais interessante a vítima sem que o herói se torne odioso - é motivo que tem sido cantado e decantado, posto em prosa e verso, para milhares de produções semelhantes. Otelo, Zaíra, Sganarello, Sonâmbula, isto é, a tragédia, o drama, a comédia e a ópera, todas filhas legítimas ou legitimadas de Melpomene, têm o mesmo fundo. A pobre mulher debaixo do peso de uma acusação que se não pode combater plausivelmente, o pobre homem, amoroso como Georges Dandin, cioso como um africano, e entre os dois um lenço, uma carta, um retrato, cujo êxito forçado é travesseiro, punhal ou cantochão da palinódia, com que se termina a festa em gargalhadas com o amém dos comparsas e regozijo dos espectadores. Daqui a moralidade que se formula neste princípio: - As aparências enganam sempre e as mulheres nunca. ${ }^{429}$

Retornando à comparação com a obra dramática de Victor Hugo, há ainda outra obra que igualmente contribui para se compreender a gênese de Leonor de Mendonça, trata-se de Ruy Blás, peça em que o lacaio apaixona-se pela rainha correspondendo, nesse sentido, ao interesse de Alcoforado pela duquesa. No prefácio, Hugo esclarece que: "O assunto filosófico de Ruy Blás é o povo aspirando às regiões elevadas; o assunto humano é um homem que ama uma mulher; o assunto dramático é um lacaio que ama uma rainha. ${ }^{\$ 30}$ No entanto, é interessante notar também a situação da rainha, a qual muito se aproxima das circunstâncias que envolvem Leonor. O dramaturgo francês explica que a rainha é infeliz como mulher, "porque é como se não tivesse marido" e como rainha, "porque é como se não tivesse rei". Ela inclina-se para os que estão abaixo dela por piedade real e ou instinto de mulher, e Ruy Blás, por sua vez, olha para cima. Destarte, Ruy Blás torna-se rei e homem para ela ${ }^{431}$ :

\begin{abstract}
A RAINHA, gravemente.
Dom César, eu vos dou a minha alma. Rainha para os demais, para vós não sou mais do que uma mulher. E eu vos pertenço pelo amor e pelo coração. Tenho fé em vossa honra como respeitareis a minha. Quando me chamardes, irei imediatamente. Estou pronta. - Ó César! Há um espírito sublime na tua cabeça. Sê orgulhoso, porque o gênio é tua coroa, a coroa que te pertence! (Beija Ruy Blás na testa). Adeus. (Ergue a tapeçaria e desaparece). ${ }^{432}$
\end{abstract}

Todavia, as falas da rainha (e de outras personagens) sugerem que mais do que a piedade e o instinto de mulher são o tédio e a solidão que a aproximam de Ruy Blás. A ausência e o desprezo do rei mínguam qualquer tentativa de envolvimento entre o casal: “[...] O rei caça. Está sempre ausente. Ah! Que enfado mortal! Em seis meses, passei

${ }^{429}$ DIAS, Gonçalves. Folhetim do Correio Mercantil. Revista Semanal. Correio Mercantil. n. 270. 30 de set. de 1849. In: GIRON, Luís Antônio. Op. Cit., p. 477.

${ }^{430}$ HUGO, Victor. Prefácio a Ruy Blás. In: Op. Cit, 1960, p. 364.

${ }^{431}$ Idem, Ibidem, p. 362.

${ }^{432}$ HUGO, Victor. Ruy Blás. In: Op. Cit, 1960, p. 449. 
doze dias junto dele." ${ }^{433}$. A esposa de Carlos II estaria disposta a amar, se fosse também amada: "Oh! Se ele tivesse querido... eu teria amado o rei. Mas ele me abandona assim, sozinha, destituída de amor." ${ }^{334}$. Igualmente Leonor afirma a disponibilidade para amar o duque, o qual, como Carlos II, prefere sair para caçar à companhia da esposa. A fala de Ruy Blás a seguir denota a vida enfadonha da rainha e a inabilidade do rei como amante e como político.

\section{RUY BLÁS.}

Escuta. Eu a espero todos os dias na sua passagem. Sinto-me como um louco! Ah! A vida dessa pobre mulher é um tecido de tédios! Sim, todas as noites fico a pensar nisso: viver nesta corte de ódio e de mentira, casada com este rei que passa todo o tempo a caçar! Imbecil! Tolo! Velho aos trinta anos! Menos que um homem! Inábil para reinar como para viver. [... $]^{\natural 435}$

Hugo também aclara em seu prefácio quais são as características precípuas de suas personagens Ruy Blás e a rainha. O lacaio representaria “o gênio e a paixão comprimidos pela sociedade" 436 e a esposa de rei Carlos seria "a virtude minada pelo tédio", predicados que podem ser vislumbrados respectivamente em Alcoforado e na duquesa. As falas do jovem cavaleiro no que concerne à forma e ao conteúdo bem como sua disposição para o amor (e morte) aproximam a figura do gênio romântico, mas, como é usual no texto gonçalvino, essa relação não é descrita de forma explícita como o é em Victor Hugo.

$\mathrm{O}$ mesmo se pode dizer sobre a virtude de Leonor ser colocada à prova devido ao tédio que recrudesce longe da corte e a distância entre ela e o marido. É preciso observar, no entanto, que Victor Hugo faz questão de pontuar no rei a incapacidade para governar ao lado da inépcia para o amor; e em Gonçalves Dias não há essa associação, ou seja, a peça se furta a fazer críticas ao duque de Bragança em relação a questões políticas.

\footnotetext{
${ }^{433}$ Idem, Ibidem, p. 408.

${ }^{434}$ Idem, Ibidem, p. 416.

${ }^{435}$ Idem, Ibidem, p. 388.

436 "O povo que tem o futuro, e que não tem o presente; o povo, órfão, inteligente e forte; colocado tão baixo e aspirando tão alto; tendo no dorso as marcas da servidão e no coração as premeditações do gênio; o povo, criado dos grandes senhores, e amoroso, na sua miséria e na sua abjeção, da única figura que, no meio desta sociedade desmoronada, representa para ele, numa irradiação divina, a autoridade, a caridade e a fecundidade. O povo seria Ruy Blás.” Prefácio a Ruy Blás. In: Op. Cit., p. 361-362.
} 


\subsection{O drama romântico}

O drama romântico herdou a estética do espetacular ${ }^{437}$ e os motivos do melodrama, invertendo-lhe os valores morais e evidenciando os problemas sociais: "Il propose au contraire une vision cynique de l'histoire faites par les grands, en donnant a voir les coulisses mesquines ou honteuses de la vie de cour." ${ }^{438}$. Essas diferenças dificultaram a aceitação do drama romântico. No entanto, é preciso ressaltar que os autores que teorizaram sobre o melodrama, como Charles Nodier (Introdução ao Théâtre choisi de Pixérecourt, 1841) e Guilbert de Pixérecourt (Últimas reflexões do autor sobre o melodrama, 1843), vinculam-no à tradição neoclássica, lembrando a ênfase dada à instrução moral, aliada ao prazer, à justiça e à virtude. No caso de Pixérecourt, há também a preferência por obedecer às regras de unidade ${ }^{439}$. Por essa razão, os teóricos costumam, mais frequentemente, vincular o drama romântico ao drama burguês, que também assinalava a liberdade de criação.

O teatro romântico teve uma lenta formação, da segunda metade do século XVIII até o início do século XIX, desde as primeiras manifestações do drama burguês, passando pelo melodrama e dramas históricos. Naugrette 440 afirma que houve um arrefecimento da censura, na França, após a Monarquia de Julho. Com essa mudança, os autores dramáticos deixaram de utilizar a história como pretexto para falar do presente. A peça Antony de Alexandre Dumas inaugura o drama em que são tratados temas contemporâneos.

Ao comentar o desenvolvimento da literatura alemã, Auerbach sintetiza como a inclusão do cotidiano e do comezinho nas obras literárias depende do advento do historicismo, ou seja, somente quando tudo aquilo que era desprezado literariamente passa a ser matéria para representar o peculiar, inclusive, os acontecimentos e contextos contemporâneos:

Quando se reconhece que as épocas e as sociedades não devem ser julgadas segundo uma concepção modelar daquilo que é digno de esforço, mas

${ }^{437}$ O espetáculo melodramático cultiva uma forma de encenação que procura afetar os sentidos por meio da exploração de recursos visuais e sonoros, como o emprego de cenários suntuosos e orquestra. Além disso, a construção dos enredos prioriza elementos que provocam diferentes sensações e emoções. BRAGA, Cláudia. Melodrama: aspectos gerais do gênero matriz da telenovela. Intercom - Sociedade Brasileira de Estudos Interdisciplinares da Comunicação. Anais. XXVIII Congresso Brasileiro de Ciências da Comunicação. Rio de Janeiro. UERJ. 5 a 9 de setembro de 2005.

438 NAUGRETTE, Florence, Op. Cit., p. 196.

${ }^{439}$ CARLSON, Marvin. Op. Cit., p. 206.

${ }^{440}$ NAUGRETTE, Florence. Op. Cit., p. 220. 
segundo as próprias pressuposições; quando se contam entre estas pressuposições não mais somente as naturais, como clima e solo, mas também as espirituais e históricas; [...] quando, finalmente, se impõe a convicção de que o importante do acontecimento não é apreensível mediante conhecimentos abstratos ou gerais, e de que o material para tanto não deve ser procurado somente nas partes elevadas da sociedade e nas ações capitais ou públicas, mas também na arte, na economia, na cultura material e espiritual, nas profundezas do dia-a-dia e do povo, porque só lá pode ser apreendido o verdadeiramente peculiar, o que é intimamente móvel, o que tem validade universal, tanto num sentido mais concreto, quanto num sentido mais profundo; então é de esperar que tais noções sejam também aplicadas à atualidade, de tal forma que ela também apareça como incomparavelmente peculiar, movimentadas por forças internas em constante desenvolvimento; quer dizer, como um pedaço da história, cujas profundezas quotidianas e cuja estrutura interna de conjunto se tornam interessantes, tanto no seu surgimento quanto na sua direção evolutiva. Ora, é conhecido o fato de que os conceitos enumerados logo acima, que se concentram todos numa determinada direção espiritual, que se chama historicismo $[\ldots]^{441}$

Para Bénac ${ }^{442}$, a liberdade de criação, inerente ao drama romântico, fez com que cada escritor criasse seu próprio gênero. Alexandre Dumas escrevia intrigas históricas com características melodramáticas. Em Victor Hugo, a tendência lírico-épica se sobrepõe. Chatterton, de Vigny, é um drama burguês com pretensões filosóficas. Já a obra de Musset, mais diferenciada, esquiva-se das classificações. Essa variedade de expressões observadas por Henri Bénac é compreensível, já que se trata de um gênero que propõe a liberdade de criação e a mistura de gêneros, além de ter se beneficiado de mudanças perpetradas anteriormente no cenário da dramaturgia.

Em Antony, considerado o primeiro drama romântico, o tema precípuo é a questão do filho ilegítimo, o que implica a discussão sobre o lugar do homem do povo na sociedade burguesa. O conflito é construído da seguinte forma: Antony e Adèle se amam e querem se casar, mas a proposta do protagonista é rechaçada por ele ser bastardo. Eles se separam, e ela se une ao Coronel d'Hervey, com quem tem filhos. Durante um baile, Adèle e Antony voltam a se encontrar. A paixão entre eles não arrefecera. O jovem apaixonado, por meio de subterfúgios, consegue ficar a sós com a amada. D’Hervey vai ao encontro da esposa e chega nesse momento. Adèle pede a Antony que a assassine para não manchar o seu nome e de sua filha. A fim de protegêla, Antony afirma ao marido: "Ela resistiu a mim, eu a assassinei".

${ }^{441}$ AUERBACH, Erich. "O músico Miller”. In: Op. Cit., 2004, p. 395.

${ }^{442}$ BÉNAC, Henri. O Romantismo Francês. Organon, v. 8, n. 8-9, 1963, p. 17-18. 
Antony desvela como a sociedade contemporânea reprime os problemas que ela mesma cria ${ }^{443}$ : "c'est elle qui, en marginalisant le bâtard, lui donne le goût effréné de sa revanche; c'est elle enfin, par ses médisances et son rejet des amants adultères, qui precipite leur fin." 444 Enquanto o drama histórico conferiu à história sentidos inerentes ao contemporâneo para fins eminentemente políticos, a proposta do drama romântico está mais relacionada à questão social. Mas sem, contudo, ao tratar do adultério na contemporaneidade, servir de "veículo para a promulgação da moralidade" 445 . "Substituindo o antigo determinismo da fatalidade trágica está o já citado determinismo social, e com ele há uma mudança de perspectiva: se, por um lado, as leis naturais são imutáveis, por outro, as leis sociais podem ser mudadas." $" 446$

Nesse sentido, em Antony, Dumas apresenta a questão do filho ilegítimo de forma que o público tenda a admirar a personagem e reconhecer a hipocrisia da sociedade em relação aos bastardos e as consequências dessa postura. Em um enredo que contempla a contemporaneidade, o drama exalta o amor, a liberdade e desvela um problema político-social. Sem ascendência e sem posses, impossibilitado de escolher a sua cônjuge, o filho ilegítimo não tem outra alternativa de relacionamento que não sejam relações adúlteras, que por sua vez, podem gerar outros bastardos.

Em Antony também se evidencia a condição social da mulher vítima da moral burguesa que é, aliás, legitimada legalmente na França pelo código civil napoleônico ${ }^{447}$, o qual reduziu as mulheres ao estatuto de minoridade, passando diretamente da tutela do pai para a do marido ${ }^{448}$. O adultério poderia ser punido mesmo sob a alegação de uma simples denúncia. A crítica à condição feminina já aparecera no drama histórico, mas será ainda mais veemente no drama romântico.

Temas que refletem as grandes questões sociais são explorados pelo drama romântico, como o casamento burguês, o adultério, a bastardia, a educação dos filhos, a

443 SANTOS, Silvia Pereira. Caminhos do drama burguês: de Diderot a Alexandre Dumas filho. Darandina: Revista Eletrônica. Programa de Pós-Graduação em Letras / UFJF, vol. 2, nº 1, p.8.

444 “(...) é ela que, marginalizando o bastardo, lhe dá o gosto desenfreado da revanche; é ela enfim, por suas maledicências e sua rejeição dos amantes adúlteros, que precipita o fim deles.” NAUGRETTE, Florence. Op. Cit., p. 154.

${ }^{445}$ CARLSON, Marvin. Op. Cit, p. 204.

446 SANTOS, Silvia Pereira. Caminhos do drama burguês: de Diderot a Alexandre Dumas filho. Darandina: Revista Eletrônica. Programa de Pós-Graduação em Letras / UFJF , vol. 2, nº 1, p.8.

${ }^{447}$ CODE CIVIL DES FRANÇAIS - Titre V - Chapitre VI. Disponível em: $<$ http://www.assembleenationale.fr/evenements/code-civil-1804-1.asp> Acesso em: 12 out. 2014.

448 "Um outro obstáculo sério à conquista da cidadania plena para as mulheres foi a ideia de 'incapacidade civil da mulher casada'. Vários países, especialmente os de tradição latina e católica, regidos por códigos civis influenciados pelo Código Napoleônico, levaram muito tempo para abolir a 'menoridade' das mulheres casadas e a obrigatoriedade de sua submissão ao marido, este, sim, considerado cidadão capaz." PINSKY, Jaime; PINSKY, Carla Bassanezin (Org.). História da Cidadania. São Paulo: Contexto, 2013. 
liberdade das mulheres, o lugar do artista e do poeta na sociedade de mercado. Além da temática, há algumas diretrizes que, promulgadas desde os dramas burgueses, serão seguidas pelos escritores do drama romântico: a crítica às regras clássicas, particularmente às unidades de tempo e de lugar, a noção de genialidade, a mistura dos gêneros que nega a unidade de tom.

No entanto, o drama romântico, diversamente do drama burguês e do melodrama, não tem como escopo resolver as questões sociais colocadas em cena, mas apenas compartilhá-las com os espectadores. Já o drama burguês propõe uma missão social. Ao invés de tratar apenas das paixões individuais como a tragédia neoclássica, ou de caracteres à maneira shakespeariana, ele representa a força moral do homem combatendo um obstáculo, ou melhor, a influência das condições sociais e familiares sobre os comportamentos. A ação da sociedade sobre o indivíduo passa a ser mais importante que a paixão das personagens. Tal paradigma será seguido tanto pelo drama histórico quanto pelo drama romântico. O romantismo tende a substituir o tema da libertação individual para os de cunho social ${ }^{449}$.

O drama diferencia-se da tragédia não pela ausência de tragicidade, mas por abolir a noção de fatalidade. No drama a ação se desencadeia com base na vontade independente do homem, em sua fixação em um objetivo. Os protagonistas dramáticos idealizam seu futuro, e esses desejos conscientes levam-nos à ação dramática que, mormente, culmina em desgraça. Mas não devido a um fado inalterável, e sim aos obstáculos sociais contrários à obtenção do que é desejado. Portanto, o destino insuperável estrutura a tragédia clássica, enquanto obstáculos sociais determinam o drama romântico ${ }^{450}$. Vale lembrar que Gonçalves Dias não só estava ciente da diferenciação entre a fatalidade da tragédia e do drama, como a discute no Prólogo de Leonor de Mendonça.

Referindo-se a Chatterton, de Vigny, Punter relaciona a questão do embate social entre o filistinismo burguês e o artista (o gênio) à maneira como as personagens interagem entre si, ou melhor, o poder econômico e social reverbera-se no poder da palavra $^{451}$. Naugrette observa ser essa peça um drama bastante moderno no que tange a sua dramaturgia do silêncio, no sentido de que os protagonistas não podem se expressar

${ }^{449}$ PRADO, Décio de Almeida. Op. Cit, 1972, p. 86.

${ }^{450}$ LUNA, Sandra. Nunca fomos tão antigos: a ação trágica como resistência ao descentramento pósmoderno. Sínteses. UNESP, 2002, p. 4-5.

${ }^{451} \mathrm{O}$ medo gerado pela falta de comunicação já transpareceria nas produções góticas revelando uma sociedade caracterizada pela divisão: a divisão entre gêneros, a divisão social, a divisão entre indivíduos. PUNTER, David. Op. Cit., p. 102. 
ou não querem fazê-lo no contexto em que estão inseridos. Há duas razões para tal estética: criticamente, a palavra e o lugar do poeta na sociedade são postos em crise e, como efeito dramático, o amor entre as personagens do drama Chatterton e Kitty Bell, socialmente coibido, também não é expresso oralmente. Vigny explica que: "Derrière le drame écrit, il y a comme um second drame que l'écriture n'atteint pas, et que n'expriment pas les paroles. Ce drame repose dans le mysterieux amour de Chatterton et de Kitty Bell; cet amour qui se devine toujours et ne se dit jamais." 452

Guardadas as devidas proporções, o amor ou o interesse de Leonor pelo jovem cavaleiro também não é explicitamente expresso, o que torna as suas ações e sentimentos imprecisos, mas verossímeis, seja porque expressar tal sentimento seria impróprio, seja por representar uma característica do feminino ${ }^{453}$. Em Vigny, aliás, o feminino inalcançável, representado pela inviabilidade de envolvimento de Chatterton com Kitty Bell, seria um signo da impossibilidade de inserção do poeta na sociedade. Em Dias também há a ideia da interdição social, pois fica sempre clara a distância hierárquica entre os duques e o ascendente a cavaleiro ${ }^{454}$

\subsubsection{Realismo Romântico}

Foi proposto acima considerar o diálogo da obra prima gonçalvina com determinados dramas, evidenciando a similaridade dos temas e das formas estéticas empregadas, bem como de que maneira conteúdo e expressão se articulam. Apesar da profunda relação estabelecida com os dramas franceses, deve-se sempre atentar para o fato de que Dias também apreciava os espetáculos líricos e tragédias, de forma que essa apreciação, algures, interferiu na configuração de seus livros. Cabe ponderar também o

\footnotetext{
${ }^{452}$ VIGNY, Alfred. apud NAUGRETTE, Florence. Op. Cit., p. 167.

${ }^{453}$ Como no mito de Tristão e Isolda, os amantes não podem e, na verdade, não querem unir-se, pois o que eles buscam é sentir o Amor-paixão e consumir-se em sua chama para então unir-se à luz. Tristão não deseja Isolda, mas sentir o Amor por Isolda: "Pois Isolda é sempre a desconhecida, o próprio enigma da mulher, representa tudo o que há de eternamente fluido, evanescente e quase hostil, ou seja, tudo o que incita à perseguição e a avidez da posse, a mais deliciosa das posses para o coração de um homem subjugado pelo mito.” ROUGEMONT, Denis. Op. Cit., p. 380.

454 Em Wuthering Heights, Cathy se identifica com o oprimido e aviltado socialmente porque é exatamente essa sua condição enquanto mulher. DIAS, Daise Lílian Fonseca. O erro trágico de Cathy em O morro dos ventos uivantes. In: XII Seminário Nacional e III Seminário Internacional Mulher e Literatura - Gênero, Identidade e Hibridismo Cultural, 12., 2007, Ilhéus, Anais do XII Seminário Nacional e III Seminário Internacional Mulher e Literatura, Ilhéus, BA: UESC/ Editus, p. 8. Disponível em: http://www.uesc.br/seminariomulher/anais/PDF/DAISE\%20LILIAN\%20FONSECA\%20DIAS.pdf. Acesso em: 20 ago. 2013.
} 
que Prado chamou de "realismo psicológico" em Leonor de Mendonça, aproximando o drama do romance Madame Bovary.

Vale lembrar com Camilo ${ }^{455}$ que o chamado realismo romântico, ou o avanço romântico em direção a um viés mais realista, se dá normalmente na representação da relação homem-mulher ao minimizar o sentimentalismo excessivo e as idealizações das relações amorosas. Segundo Volobuef ${ }^{456}$, esse 'realismo' se configura a partir da tendência de nossa novelística em registrar a paisagem brasileira desenvolvendo um agudo senso de observação. Em Leonor de Mendonça esse olhar arguto recai sobre a percepção de como as estruturas sociais interferem nos relacionamentos. E o suposto contrassenso se dá na justaposição de elementos românticos de idealização do amor com ações menos idealizadas, conforme veremos a seguir.

Arêas concorda em salientar uma forma de "bovarismo avant la lettre" em L.M. e expõe algumas características do drama gonçalvino que se assemelham à obra de Flaubert: a jovem duquesa em terras pequenas sente-se entediada e infeliz, já que não ama e nem compreende o marido. A sua falta de experiência ou "inocente leviandade" faz com que o desejo por Alcoforado a deixe confusa. À hora da morte sobressai o seu “temperamento vital" adensado por seus outros já citados predicados, a saber, juventude e inexperiência ${ }^{457}$.

Décio de Almeida Prado pondera que no instante em que Alcoforado sucumbe, há uma quebra da convenção romântica pautada na ideia de amor cortês. Leonor não deseja sacrificar a si mesma, seja morrendo na companhia do jovem mancebo ou arruinando a sua reputação. Nesse sentido, o crítico cita dois momentos cruciais da peça, quando Leonor impede que Antônio Alcoforado se jogue da janela, o que, de qualquer maneira a incriminaria, e a própria morte do rapaz, que não é sequer lamentada pela duquesa.

${ }^{455}$ CAMILO, Vagner. Op. Cit., p. 66.

456 VOLOBUEF, Karin. Frestas e arestas: a prosa de ficção do Romantismo na Alemanha e no Brasil. São Paulo: Fundação Editora da UNESP, 1999, p. 227.

${ }^{457}$ É interessante comparar Leonor de Mendonça e Madame Bovary com base nas ideias expostas por Balzac em seu texto Physiologie du mariage, o qual, segundo Gay, expõe uma opinião corrente no século XIX sobre a relação da mulher com o adultério: “'Numa bela manhã de primavera, na manhã seguinte a um baile, ou no dia anterior a uma excursão ao campo', as indicações isoladas da desilusão conjugal se aglutinam num projeto mudo e ainda rudimentar de infidelidade. 'Sua mulher está entediada, e o prazer legítimo já não a atrai mais. Seus sentidos, sua imaginação, talvez o capricho da natureza, clamam por um amante'. É pouco provável que ela embarque de imediato num caso amoroso; seu marido continua a ter algum mérito aos seus olhos, e os riscos de um envolvimento ilícito são grandes. Mas a imaginação da mulher foi espicaçada justamente porque perdeu suas ilusões. Agora, o adultério é apenas questão de tempo e de oportunidade. Só precisa de um homem solteiro alerta e sequioso que saiba, por experiência, ler os sinais de problemas no casamento." GAY, Peter. Op. Cit., p. 69. 
Para compreender esse rompimento com a ideologia romântica que vinha sendo o norte do drama até esse ponto, sobretudo levando em conta a figura do cavaleiro, pode-se sopesar a observação disposta por Vilma Arêas de que, como havia feito anteriormente nas Sextilhas de Frei Antão, Dias faz uso da ironia desconstruindo um tema caríssimo aos românticos: o mote do amor e morte. Vagner Camilo denota a estranheza desse "riso irônico e sorrateiro" em meio à austera poesia de Gonçalves $\operatorname{Dias}^{458}$.

\begin{abstract}
Gonçalves Dias que, inspirado nas mistificações literárias de Thomas Chatterton compôs as Sextilhas de Frei Antão, obra ímpar em nossa literatura, quer pelo inesperado da matéria tratada e pelo experimento com a linguagem e o estilo; quer pelo riso irônico e sorrateiro, 'que secretamente abre caminho na poesia carrancuda de Gonçalves Dias', quer ainda por assumir deliberadamente o risco da ruptura com a expectativa média (e patriótica) do público do tempo. ${ }^{459}$
\end{abstract}

Essa postura irônica na obra gonçalvina é realmente inusitada, mas essa verve pode ser vislumbrada, por outro lado, em duas cartas endereçadas aos amigos Antônio Henriques Leal e Alexandre Teófilo de Carvalho Leal respectivamente. Essas cartas são bastante sintomáticas, em uma, de 06 de abril de 1847, Dias faz uma espécie de autoparódia do poema "Seus Olhos"460 e na outra, de 20 de dezembro de $1861^{461}$, a já citada missiva que trata da viagem ao Amazonas, ele desconstrói a imagem sublime que fizera do rio e sua floresta.

A ironia em Leonor de Mendonça, no entanto, se diferencia da forma empregada nas Sextilhas de Frei Antão, cujo riso, embora sutil, é aparente e se conforma nas falas do frei-narrador. Ela se configura na tensão entre o paradigma pautado na apropriação dos valores medievais pelo romantismo, sobretudo no que concerne ao amor cortês, e o "realismo psicológico" subsumido na representação do "autoritarismo realista do poder

\footnotetext{
${ }^{458}$ Camilo adverte que o primeiro a vislumbrar o sutil humor presente nas Sextilhas de Frei Antão foi Carlos Drummond de Andrade em: "O Sorriso de Gonçalves Dias". Consultamos a edição: Confissões de Minas. São Paulo: Cosac Naify, 2011, p. 37-44.

${ }^{459}$ CAMILO, Vagner. Op. Cit., p. 46.

460 "Meus olhos tão negros, tão belos, tão puros, /Já olhos não são:/São olhos modestos de noiva formosa, /Pregados no chão;/ Um pai de família dos mais acabados,/Do Rego farão,/Agora só falam do santo consórcio/Como de um sermão./Sei ora o que valem, pois fazem milagres./Mais uma razão/Porque eu assim brado que aqueles meus olhos/Meus olhos não são./Aqui fixo os meus olhos, para os não abrir mais à luz do dia: eu amo/ a escuridão,/Que a noite veda ver mistérios/De familiar aconchego - Filinto." DIAS, Gonçalves. Correspondência. In: Op. Cit., p. 1066-1067. 461 "Mas...

Eu que cometo insano e temerário?

Musa, onde me sobes?! - Desce, vadia, senta-te com propósito, e conta-nos...

Ai!... já me esquecia que se tratava de pragas, micuins, e miudezas quejandas!” Idem, Ibidem, p. 1120.
} 
aristocrata" ${ }^{62}$. O elemento dissonante, o cunho realista da peça, frusta as expectativas de uma incondicional apropriação do mito de amor e morte, mas proporciona uma reflexão sobre o que parecia ser um discurso unilateral ${ }^{463}$. Dito de outra forma, ao minorar a perspectiva romântica questionando o modelo do amour courtois, a crítica social em relação à tirania (do duque e do marido) torna-se mais explícita.

Assim, no drama, a quebra da convenção amorosa cortês se coaduna com a proposta (inúmeras vezes aludida neste trabalho) de empregar a fatalidade não mais como previa a tragédia clássica, e sim pelo prisma historicista. Ao colocar as relações sociais em primeiro plano, a atitude da duquesa torna-se bastante verossímil. Alcoforado servira apenas como distração e lenitivo para o seu tédio e solidão; foram as circunstâncias (e as convenções sociais) que fizeram com que a situação se tornasse uma tragédia.

O desprezo ou o tratamento que Leonor reserva a Alcoforado confirma a importância do tema das relações entre diferentes classes no drama. O jovem tem consciência dessa diferença e acusa a duquesa de atuar de acordo com as prerrogativas da nobreza enquanto ele age movido pelo sentimento. A ironia em relação ao amor romântico já se infiltrara sutilmente antes do desfecho. No excerto a seguir, quando a duquesa de Bragança ${ }^{464}$ pede a Antônio Alcoforado que se levante para que ninguém o flagrasse ajoelhado diante dela, é possível notar o exposto acima:

A DUQUESA - Levantai-vos, levantai-vos... Esta manhã, quase que vos surpreenderam aos meus pés. Meu Deus! Que terror que eu tenho!

ALCOFORADO - Vede!... Dizeis que estamos a sós, e toda vos atemorizais por cair eu a vossos pés.

A DUQUESA - Não seria isso imprudência?

ALCOFORADO - Muito prudente sois vós, Sra. Duquesa! Quando o meu sangue corresse em ondas sobre o assoalho da vossa habitação, fora prudência e até delicadeza, mandar limpá-lo bem depressa para que os vossos pés se não manchassem nele.

A DUQUESA - Sois injusto!

ALCOFORADO (despeitoso) - Serei, senhora.

A DUQUESA - Não percebeis vós que a prudência é para mim um dever?

ALCOFORADO - E também para o homem; contudo, se eu só houvesse consultado a prudência, não teria há pouco arremessado o meu venábulo, porque ao invés de vos salvar poderia errar o tiro e atravessar-vos com ele; se eu houvesse consultado a prudência, não me teria interposto entre vós e o javali, porque o javali poderia espedaçar-me; se eu houvesse consultado a

\footnotetext{
${ }^{462}$ ARÊAS, Vilma. Op. Cit., 2013, p. 242.

${ }^{463}$ ALAVARCE, Camila da Silva. A ironia e suas refrações: um estudo sobre a dissonância na paródia e no riso. São Paulo: Cultura Acadêmica, 2009, p. 15.

${ }^{464}$ A propósito, Aguiar comenta que a ironia perpassa as falas da duquesa, mas não explica como isso se dá e nem exemplifica a sua proposição, provavelmente devido à natureza sintética de seu texto. AGUIAR, Flávio (Org.). Op. Cit., p. 69.
} 
prudência... oh! não me teria em corpo e alma dedicado a uma pessoa da alta nobreza, que eu sei que não tem amor senão aos seus títulos, que não tem olhos senão para as suas louçanias. ${ }^{465}$

Âreas consegue resumir de forma bastante arguta o efeito desse rompimento com as convenções românticas. A estudiosa assevera que no instante em que Leonor em vez de proceder como uma heroína romântica se compadece de si mesma e deseja viver, o 'grandioso' cede ao 'demasiado humano', estabelecendo-se assim um efeito irônico. Pode-se ainda complementar a observação de Arêas dizendo que ao optar pelo registro do 'humano', a peça permanece grandiosa, alcançando assim o que propusera Hugo para o drama: fundir, conforme suas palavras, o grande e o verdadeiro.

${ }^{465}$ DIAS, Gonçalves. Op. Cit., p. 933-934. 


\subsection{Considerações sobre determinadas falas das personagens e o estilo de linguagem}

A ideia de moderação remete às produções literárias neoclássicas, e a linguagem gonçalvina caracteriza-se por manter esse atributo em sua obra preferindo pautá-la pela clareza. No caso de Leonor de Mendonça, deve-se destacar a opção de fazer uso do verso e da prosa sintetizando os dois registros, ou seja, nos trechos em que há expressão de "um sentimento nobre ou uma exaltação do espírito" 466 , as personagens utilizam a prosa poética.

A tentativa de conciliar a espontaneidade romântica com o controle clássico também transparece na poética gonçalvina como notou Peres em seu estudo sobre três hinos do poeta, "O Mar", "A tarde" e "Adeus":

\footnotetext{
Nos três hinos de Gonçalves Dias analisados aqui, em particular "O Mar" e "Adeus", nota-se de fato um esforço em buscar uma medida, sugerindo uma contenção neoclássica que possa equilibrar a tendência à dispersão romântica: o ímpeto da natureza em estado bruto é contrabalançado por um sentimento ordenador. ${ }^{467}$
}

Vale lembrar que para os primeiros românticos alemães, a fusão entre prosa e poesia se liga à tentativa de aproximar arte e vida ${ }^{468}$. Eles queriam, ao mesmo tempo, conferir autonomia à arte e integrá-la ao cotidiano. Já na peça em questão a proposta é utilizar a poesia apenas nos momentos em que os sentimentos são mais exacerbados para comover o público, e empregar termos e expressões mais ordinários nas situações prosaicas para manter o efeito de verossimilhança.

Lembre-se que, no Prólogo, o autor discute a questão, pautando-se na fusão dos gêneros e no exemplo de Shakespeare. Recorde-se que ele explica que antes havia apenas dois gêneros mais reputados, a tragédia que tratava dos "grandes", e a comédia que abordava de forma cômica "os pequenos". Para fundir os dois gêneros, o drama reduz a gravidade da tragédia pela introdução de elementos da vida doméstica e dos costumes. "Bem é que haja harmonia entre a expressão e o pensamento, que a poesia do espírito seja interpretada pela poesia das palavras, e que o prosaico da vida seja dito em linguagem prosaica." 469

\footnotetext{
${ }^{466}$ Idem, ibidem, p. 908.

${ }^{467}$ PERES, Marcos Flamínio. Op. Cit., p. 173.

${ }^{468}$ DUARTE, Pedro. Op. Cit., p. 116.

${ }^{469}$ DIAS, Gonçalves. Prólogo a Leonor de Mendonça. Op. Cit, p. 908.
} 
Fica patente a sua procura por um gênero adequado à sua época, pela via da adaptação e da transformação do exemplo shakespeariano, verdadeiro farol para as mentes românticas. A necessidade de um ajuste entre expressão e pensamento é outro forte indício de seu Romantismo - a busca de uma forma que expresse o anseio autoral. ${ }^{470}$

Assim, a harmonia da expressão, o uso simultâneo do verso e da prosa, em Gonçalves Dias, se relaciona com a ideia de fusão de gêneros, um princípio romântico. Mas como já se sabe, ele optou por não fazer o uso de ambos os registros, o poético e o prosaico, porque temeu que o malogro de sua peça consequentemente denegrisse o uso dessa inovação acarretando o retardamento da arte. De qualquer modo, nota-se um esforço nesse sentido, pois, nos trechos mais patéticos, preocupou-se com a criação melódica do trecho e o uso de recursos estilísticos, como no excerto a seguir:

\begin{abstract}
ALCOFORADO - Escuta-me, Sra. Duquesa. As pessoas da vossa hierarquia têm às vezes necessidade urgente de um homem resoluto e discreto que marche afoitamente por meio das trevas sem temer os golpes de um punhal traiçoeiro, nem a morte obscura e sem glória, que em meio delas o poderá alcançar: têm às vezes caprichos imperiosos, e para os satisfazer é preciso todo o aparelho da tortura e todo o horror do cadafalso. Assim mo disseram. Se alguma vez tiverdes um desses caprichos ou uma dessas necessidades, dizei-me - vai! E eu andarei por meio das trevas; - sofre! E eu me sujeitarei à tortura; - morre! e eu subirei ao cadafalso. ${ }^{471}$
\end{abstract}

O paralelismo - em, "têm às vezes necessidade [...] têm às vezes caprichos imperiosos" -, a repetição de palavras, o polissíndeto, a gradação ("E eu andarei por meio das trevas;" [...] "E eu me sujeitarei à tortura; [...] e eu subirei ao cadafalso.) e a aliteração em /t/ são elementos que colaboram com a construção rítmica do trecho. Observa-se também como no trecho final as sílabas fortes conformam-se ao sentido, pois destacam-se as palavras: vai/trevas; sofre/tortura; morre/cadafalso que remetem ao destino do cavaleiro.

Alcoforado tem uma nova chance de falar com a Duquesa a sós após tê-la salvo do incidente da caçada. Ele declara o seu amor submisso e desmedido em registro poético, notório no exemplo a seguir:

ALCOFORADO - Que sois vós! Sei-o eu porventura? Sois o objeto que me fere continuamente os sentidos, a ideia que tenazmente me ocupa a alma, a imagem que veio sentar-se imperiosamente à minha cabeceira, e dizer-me: 'não terás olhos senão para mim', a voz que me brada a todo

${ }^{470}$ WERKEMA, Andréa Sirihal. Op. Cit., p. 193.
${ }^{471}$ DIAS, Gonçalves. Op. Cit., p. 918. 
instante: 'não terás ouvidos senão para mim', o fantasma que me prende, que me enlaça nas asas da esperança, que me abate no abismo da desesperação, e que me repete sempre e sempre: 'morrerás por mim!' Tentei resistir a esta ideia, a esta imagem, a este fantasma; não o pude, que mais podia a fascinação do que a minha vontade. Evoquei o amor de família, as afeições que eu há pouco sentia ardentemente por meu pai, nobre velho cuja mão descansa sobre a minha cabeça como no bordão da sua velhice; por meu irmão, jovem esperançoso, que vai no caminho da vida medindo os seus passos sobre os meus passos; por minha irmã, donzela extremosa que se apegou ao meu destino como hera ao muro mal construído, que está prestes a desabar; e as minhas afeições foram mudas, e os meus olhos cegos, e os meus ouvidos surdos... Só essa imagem cintilava na minha vida como uma santa numa capela ardente, cercada de turíbulos e envolta em ondas de incenso. Deixei-me arrastar por ela. Cedi; perdime. $^{472}$

Os recursos poéticos são similares aos do exemplo anterior. Os paralelismos estruturais ('não terás olhos senão para mim', / 'não terás ouvidos senão para mim'; “e as minhas afeições foram mudas, e os meus olhos cegos, e os meus ouvidos surdos..."), a gradação (“Deixei-me arrastar por ela. Cedi; perdi-me.”) e as hipérboles (“o fantasma [...] que me abate no abismo da desesperação") são utilizados para adensar a expressão do sentimento que o desespera. Além disso, todos esses recursos (o paralelismo, a gradação e o polessíndeto) colaboram para criar um efeito de acúmulo e grandiosidade, tornando sublime o objeto da descrição ${ }^{473}$. Note-se também o uso de rimas internas em "capela" e "ela", projetando uma espécie de eco que remete mais uma vez à sacralização de Leonor. Além disso, consoantes que são próximas quanto ao modo de articulação, as dentais (/f/, /v/), as labiodentais (predominantemente /t/, /d/, e /n/ com menos constância) e as bilabiais ( $p, b, m$ ), juntamente com as vogais abertas (com maior presença do $/ \mathrm{a} / \mathrm{e} / \varepsilon /$ ), pontuam o ritmo, acelerando-o de modo a exprimir obstinação e arrebatamento. As vogais abertas também servem para imprimir a ideia de momento epifânico que a presença da duquesa tem para Alcoforado, a qual é confirmada no trecho: "Só essa imagem cintilava na minha vida como uma santa numa capela ardente". O ritmo marcado pelos fonemas mencionados é parcialmente quebrado nas orações que versam sobre a imagem de Leonor por meio de uma comparação (santa, ardente, envolta em ondas de incenso). Nesse trecho há a superposição de nasais que reverberam a atmosfera de envolvimento e inescrutabilidade. Vale considerar novamente que no

\footnotetext{
${ }^{472}$ Idem, ibidem, p. 931.

${ }^{473}$ BURKE, Edmund. Op. Cit., p. 84-85. Nesse sentido, vale lembrar também a afirmação de Weiskel de que o sublime é construído por meio do sentimento e do discurso, cujo conteúdo se afirma na ideia de que o homem pode transcender o humano. WEISKEL, Thomas. O sublime romântico: estudos sobre a estrutura e psicologia da transcendência Trad. Patrícia Flores da Cunha. Rio de Janeiro: Imago, 1994, p. 17.
} 
romantismo há a tendência de representar o feminino envolto por uma atmosfera de mistério, disposição já antevista no Trovadorismo, que se coaduna à ideia de que a mulher representa o desejo e, portanto, algo que jamais cabe na própria representação: "Que sois vós! Sei-o eu porventura". A associação entre o sentimento experimentado diante de Leonor com uma ideia de indefinição, de imensurabilidade, de incompreensão já transparecera na primeira conversa privativa entre o mancebo e a duquesa:

\begin{abstract}
ALCOFORADO - Que sei eu, Sra. Duquesa? Eu mesmo não sei o que digo; mas já que principiei a dizer-vos destas coisas que não compreendo, e que todavia não posso esconder-vos por mais tempo, deixai que as diga por uma vez, e podeis ordenar-me que não mais apareça diante de vós... Oh! Não; daime um castigo bem rigoroso, mas não me exileis da vossa presença. 474
\end{abstract}

Conforme mencionado anteriormente, as metáforas do fantasma e da santa citadas em trecho acima transcrito remetem à ideia da representação da mulher como uma imagem espiritual, uma configuração de um ideal almejado. A propósito, Karin Volobuef, ao comparar a divulgação e o significado desse tema romântico no Brasil e na Alemanha, apresenta um texto de Hoffman (Die Jesuiterkirche in G.) como exemplo do conceito espiritual do amor, o qual, nesse sentido, parece esclarecer a fala do jovem Alcoforado: "Die vollen Sonnenstrahlen fielen in das Engelsgesicht. - Sie schaute mich an mit unbenschreiblichen Blick. - Die heilige Katharina - nein, mehr als sie - mein Ideal, mein Ideal war es!...” 475 .

É preciso advertir, no entanto, que a autora diferencia o escopo dessa valorização do feminino no Brasil e na Alemanha. Para a estudiosa, na prosa brasileira o amor idealizado mormente se concretiza no consórcio burguês, enquanto nos textos alemães ele permanece inconcluso representando o entusiasmo criador do fazer artístico. Dessa forma, em certos romances românticos brasileiros, por intermédio do casamento, valoriza-se a escolha individual, independentemente das barreiras sociais, o amor em si mesmo; na prosa romântica alemã, por intermédio do amor, valoriza-se a $\operatorname{arte}^{476}$.

No caso do drama em questão, essa conclusão não é pertinente, pois, em L.M., embora o amor permaneça inconcluso e se torne uma finalidade em si para Alcoforado,

\footnotetext{
${ }^{474}$ DIAS, Gonçalves. Op. Cit., p. 918.

475 "Os raios do Sol caíram em cheio sobre o semblante angelical. Ela me contemplava com um olhar indescritível. - Era Santa Catarina - não, mais do que isso - meu ideal, era meu ideal!..." HOFFMANN, E.T.A. Die Jesuiterkirche in G. In: Fantasie und Nachtstücke. München: Winckler, 1976b, p. 432 apud VOLOBUEF, KARIN. Op. Cit., p. 371.

${ }^{476}$ Idem, ibidem, p. 378.
} 
na peça também se pontua o desejo de superar os obstáculos impostos pela hierarquia social. Como observa Octavio Paz, a transgressão social não se dissocia da realização amorosa:

\begin{abstract}
O sonho de uma comunidade igualitária e livre, herança comum de Rousseau, reaparece entre os românticos alemães unido, como em Hölderlin, ao amor, só que agora de maneira mais violenta e definida. Todos esses poetas veem o amor como uma transgressão social e exaltam a mulher não só como objeto, mas como sujeito erótico. ${ }^{477}$
\end{abstract}

No amor romântico como uma revivescência do amor-paixão do Trovadorismo ${ }^{478}$ há a necessidade do obstáculo. Uma das barreiras interposta entre os amantes é o casamento, que se tornara um simples dever ou uma conveniência. Chatterton, de Vigny, e Leonor de Mendonça, de Gonçalves Dias, são exemplos do protesto romântico pelo direito de amar.

Delicados vínculos sentimentais unem senhoras casadas - Kitty Bell, escravizada pela incompreensão burguesa, e Leonor de Mendonça, subjugada à prepotência aristocrática do marido - a rapazes que, embora sejam socialmente inferiorizados, deixam-nas vislumbrar a possibilidade da felicidade afetiva. Chatterton e Alcoforado, mesmo que não deixem assomar a violência e a revolta como o bastardo Antony, são heróis antitéticos na medida em que arrancam as protagonistas de sua apatia, sentimentalmente roubando-as ao marido e à sociedade, e transfigurando-as através da paixão ${ }^{479}$.

$\mathrm{Na}$ fala da camareira Paula transcrita a seguir é possível vislumbrar essa associação entre herói e rebeldia. As palavras da empregada, à primeira leitura, assumem um tom jocoso, mas elas condensam um traço do jovem cavaleiro. A obstinação de Alcoforado se expressa por meio do amor proibido, sentimento que desafia as regras sociais, principalmente, devido ao seu caráter desmesurado e pertinaz:

477 PAZ, Octavio. Os filhos do barro: do romantismo à vanguarda. Trad. Ari Roitman e Paulina Watch. São Paulo: Cosac Naify, 2013, p. 50.

478 "Segundo a tese oficialmente admitida, o amor cortês nasceu de uma reação contra a anarquia brutal dos costumes feudais. Como se sabe no século XII o casamento havia se tornado para os senhores um puro e simples meio de enriquecimento e de anexação de terras oferecidas em dote ou prometidas em herança. Quando o 'negócio' fracassava, repudiava-se a mulher. O pretexto do incesto, curiosamente explorado, não sofria objeção por parte da Igreja: bastava alegar, sem muitas provas, um parentesco até o quarto grau para obter a anulação. A esses abusos, que suscitaram querelas infindáveis e guerras, o amor cortês opõe uma fidelidade independente do casamento legal e fundada exclusivamente no amor. Chega ao ponto de declarar que o amor e o casamento não são compatíveis [...]" ROUGEMONT, Denis de. Op. Cit. P. 48.

${ }^{479}$ PRADO, Décio de Almeida. In: GUINSBURG, J. (Org.), Op. Cit., p. 177. 
Paula - Eu lhe pedirei, Sra. Duquesa; e se ele a recusar... Oh! Então nós o faremos julgar contumaz e revel, e como tal degradar para alguma das sete partidas do mundo, com baraço ao pescoço e pregão que diga: Cavaleiro, descortês e descomedido degradado por amor. ${ }^{480}$

Além dessa fala, há outra colocação da camareira que contribui para delinear a personagem Antônio Alcoforado, comparando-o a Hermigues, o Traga Mouros, e Leonardo, o cavaleiro namorado. As referências, como bem observou Arêas ${ }^{481}$, vão além do gosto pelo medievalismo e incitam outras reflexões sobre a configuração das personagens. Figura lendária portuguesa, Gonçalo Hermigues ${ }^{482}$ é um guerreiro do tempo de Afonso Henriques conhecido por seus dons poéticos e ódio contra os mouros. Ele se apaixona pela moura Oriana e numa das empresas contra os mouros em Alcácer do Sal rouba a amada. Leonardo é uma personagem camoniana da Ilha dos Amores que persegue a ninfa Efire. Ela sente tanto prazer em ouvir as súplicas do enamorado que foge para assim continuar a escutar seus apelos ${ }^{483}$.

A breve e simples descrição das figuras mencionadas por Paula é suficiente para se perceber que a escolha não foi aleatória. Alcoforado compartilha algumas das características inerentes a essas personagens, por exemplo, a verve poética de Gonçalo ${ }^{484} \mathrm{e}$ "ser com amores mal afortunado" 485 como o soldado camoniano. Além disso, deve-se considerar que a citação de Hermigues e Leonardo permite uma aproximação de Leonor com as personagens femininas correspondentes, a moura Oriana e a ninfa Efire. A primeira é vítima da violência de Gonçalo Hermigues ${ }^{486}$, pois é raptada e afastada dos seus e da sua cultura para tornar-se esposa do português e converter-se ao cristianismo, quando é batizada como Fátima. Já a ninfa camoniana finge fugir do enamorado, como instruíra Vênus, para que, com esse estratagema, aguce ainda mais o desejo do cavaleiro. Assim, pode-se conjecturar certa equivalência no

\footnotetext{
${ }^{480}$ DIAS, Gonçalves. Op. Cit., p. 916.

${ }^{481}$ ARÊAS, Vilma. Op. Cit., 2013, p. 240.

${ }^{482}$ Vale lembrar que a lenda de Gonçalo Hermigues é narrada nas Sextilhas de Frei Antão. A propósito, na versão gonçalvina, Hermigues e Fátima não se apaixonam antes do ataque dos cristãos a Alcácer do Sal como contam várias versões da história. Há também uma versão baseada na Crônica de Cister (livro 6, cap. I) no quinto volume de $O$ Panorama do ano de 1841, p. 349-351.

483 Arêas sugere que o episódio da Ilha dos amores aludido cria "sombras em torno do retrato unidimensional de Leonor", revelando certa leviandade e egoísmo. Ibidem, Idem.

${ }^{484}$ Cabe aqui relembrar a magistral formulação shakespeariana que ajuda a esclarecer a associação entre Alcoforado e o (cavaleiro) poeta: "O lunático, o amante e o poeta/São todos compostos de imaginação." apud GAY, Peter. Op. Cit., p. 62.

${ }^{485}$ CAMÕES, Luís. Op. Cit., p. 338.

486 "Ei-lo [Gonçalo Hermigues] vai per entre os mouros, /Abre entre eles larga estrada;/Quem fica em prisão de guerra,/Quem lá foge em debandada!/Ficam moiras prisioneiras,/Mulheres - gente coitada!” DIAS, Gonçalves. Sextilhas de Frei Antão. In: Op. Cit., p. 362.
} 
sentido de que na conformação de Leonor se condensam a submissão de Fátima e o artifício de Efire.

Note-se que os exemplos de prosa poética citados são falas do jovem Alcoforado que é um representante de um estrato mais baixo da nobreza e dependente da casa de Bragança, ou seja, é sintomático que não apenas no âmbito das ações, mas também no da linguagem, haja uma inversão da lógica social pautada na hierarquia e caiba ao jovem de camada social mais desfavorecida a nobreza dos atos e da elocução. A superioridade de Alcoforado no que concerne ao estilo da linguagem ${ }^{487}$, em comparação à personagem do duque, fere a hierarquia de classe indo ao encontro dos princípios de cunho burguês em que a fidelidade e o sentimento são superiores à etiqueta, a qual, aliás, serve para figurar as diferenças sociais.

A relação entre as personagens de Leonor de Mendonça baseia-se nessa etiqueta de corte que reverbera o lugar de cada um na divisão de classes. Nesse sentido, aquilo que Gonçalves Dias chama de urbanidade seria o resultado do processo de autocoerção que alcança uma espécie de plenitude nas regras de etiqueta das cortes absolutistas dos séculos XVI e XVII. Embora as personagens sigam os paradigmas de uma sociedade hierarquizada, somente o duque identifica-se com eles, mostrando-se cioso de sua nobreza ${ }^{488}$, enquanto os outros caracteres apresentam uma crença na superioridade dos sentimentos e das emoções, aproximando-se do ethos burguês.

$\mathrm{O}$ autor entrecruza os dois estilos de vida, demonstrando simpatia pelas personagens que preferem a sinceridade dos sentimentos em detrimento da artificialidade das regras de corte ${ }^{489}$. A desvalorização da nobreza também transparece no próprio título da peça, pois o autor elege o nome de batismo da protagonista em detrimento de sua qualificação hierárquica. À duquesa de Bragança resta-lhe a humanidade, simbolizada pelo sangue derramado e pela infelicidade.

A DUQUESA - Bem quisera eu deixar-te uma lembrança, boa Paula: mas
que posso eu agora? Entrei para esta casa coberta de veludos, e hei de sair
vestida com a mortalha: entrei nova e cheia de inocência, e hei de sair ainda
nova, mas infamada!... A vossa pobre duquesa, mais pobre do que vós outras,

487 Numericamente as falas de Alcoforado também excedem às do duque. O maior número de falas, porém, cabe à Leonor de Mendonça.

488 "A ascensão ou a queda em tal hierarquia significava tanto para os cortesãos quanto o ganho ou a perda do comerciante em seus negócios. E o pavor de um cortesão ante a ameaça de declínio de sua posição e de seu prestígio não era menor do que o pavor de um comerciante ante a ameaça de perda de capital ou o de um administrador ou funcionário ante a ameaça de perder seus cargos." ELIAS, Norbert. Op. Cit., 2001, p. 111.

${ }^{489}$ CHARTIER, Roger. In: Op. Cit., ELIAS, Norbert. Op. Cit., 2001, p. 20-21. 
nada tem para recompensar os bons serviços dos seus fiéis servidores. Escuta: quando eu for morta, tomarás para ti o meu livro de orações, e escreverás na primeira página o meu nome com o meu sangue; não creias que ele seja vil porque o hão de derramar vilmente!... Não lhe ponhas título nenhum, só o meu nome de batismo; e quando rezares lembra-te da infeliz Leonor, e dá-lhe uma das tuas orações. ${ }^{490}$

Outro trecho em que as questões de classe são colocadas em xeque por meio da estruturação das falas é o primeiro diálogo entre a duquesa e Alcoforado. Na Cena IV do primeiro Ato, há uma inversão na extensão das falas. No início da conversa, Leonor procura dizer apenas o essencial, servindo-se de frases curtas e objetivas, enquanto o jovem aproveita a oportunidade para despejar os seus sentimentos fazendo uso de longos períodos cujo conteúdo é permeado de figuras poéticas.

Com medo da situação e dos rumos que a entrevista poderia tomar, Leonor reage. Como ela é hierarquicamente superior a ele, impõe ao cavaleiro que ele vá lutar em ultramar. Sentindo-se um pouco mais segura, suas falas tornam-se mais reveladoras e extensas. A partir daí o jogo amoroso se intensifica e passa a ser simbolizado pela fita que havia sido roubada pelo jovem cavaleiro e reavida pela duquesa durante essa conversação. No final desse diálogo, contraditoriamente, Leonor oferece-lhe a fita que havia retomado. Nesse trecho as rubricas são imprescindíveis para estabelecer o clima de sedução que a cena envolve.

Antes de entregar a fita ao jovem como uma memória, ela brinca com o objeto e sintomaticamente pergunta: "- Não é isto o que desejais possuir?”, conferindo ao seu adorno um caráter metonímico, o que explica o entusiasmo do cavaleiro configurado em sua última fala dessa passagem. A cena é brilhante, a estrutura do diálogo na qual a extensão e o predomínio da fala variam, as figuras de linguagem como o uso de metáforas, da gradação e da metonímia, o significado simbólico da fita, a discriminação das ações nas rubricas, tudo colabora para imprimir a oscilação e a ambiguidade que um jogo amoroso implica.

As falas do segundo Quadro, do primeiro Ato, também são bastante ambíguas, pois além de apresentar o sentido literal, a duquesa narra o acidente da caçada a Paula, elas antecipam a fatalidade que o triângulo amoroso entre d. Jaime, Leonor e Alcoforado implicará. Leonor explica a camarista que, durante a caçada, o duque embrenhou-se pela floresta, e os cavaleiros que a guardavam foram abandonando-a "insensivelmente". De repente, seu cavalo desembestou, ela perdeu o tino. Tentou

\footnotetext{
${ }^{490}$ DIAS, Gonçalves. Op. Cit., p. 958.
} 
reverter a situação puxando as rédeas do cavalo, mas, contrariamente a sua vontade, o movimento provocou a sua própria queda.

As ações narradas por Leonor parecem ter um caráter metafórico ${ }^{491}$, pois a ideia de que a duquesa sente-se sozinha e abandonada alude a sua própria situação conjugal. Em seguida, é possível associar o seu sentimento por Alcoforado com a perda do tino e o desembestar do cavalo, situação que ela embalde tenta reverter. Pois, a insensatez neste caso acaba por lhe fazer cair, assim como a sua imprudência ao marcar a entrevista noturna com o jovem cavaleiro the será fatal. Se pensarmos com Correia que o javali simboliza a ira do duque, é significativo que a medrosa duquesa tome a coragem de se interpor entre o cavaleiro e o animal.

\begin{abstract}
Se o relato do episódio, feito anteriormente a Paula por Leonor, já codificara, para o público, o javali como signo premonitório de morte, a fala de Alcoforado confirma essa codificação, nela precisando os papéis de vítima/algoz, e injetando no signo javali um novo valor, o de metáfora da força e violência do Duque de Bragança. No discurso deste, opera-se nova redundância da significação aziaga do javali, quando ele o articula com a imagem do cadafalso do pai, pressentindo a repetição no futuro iminente, da catástrofe do passado remoto. ${ }^{492}$
\end{abstract}

A associação entre o ataque do javali com a vingança do duque de Bragança fica evidenciada em uma fala do nobre em que ele prevê a inevitabilidade de uma desgraça.

DUQUE (entrando desalinhado e com os cabelos em desordem) - O javali esteve a despedaçá-la... o venábulo roçou-lhe o rosto... e eu vejo ainda o cadafalso de meu pai!... Crime ou fatalidade, um deles me está iminente; mas qual? Isto não é superstição, é um presságio, uma intuição do futuro. Vejo o relâmpago, o raio não tardará a cair... mas sobre quem?... Por quê?... Não o

\footnotetext{
${ }^{491}$ É interessante notar que em Beatriz Cenci G. Dias utiliza o mesmo recurso quando Beatriz narra à madrasta, D. Lucrécia, as suas impressões sobre o primeiro baile que presenciou. A descrição do efeito que o primeiro vislumbre de uma festa patrocinada pelo pai, D. Francisco, causou em Beatriz fazendo-a perder os sentidos simboliza a sedução da qual ela será vítima. O uso de figuras de linguagem como a sinestesia, a repetição e a hipérbole contribuem para efetivar essa orientação semântica. $\mathrm{O}$ arroubo que sente ao espreitar o sarau refletem a fascinação e o entusiasmo pelo amor demonstrado pelo pai (que antes a deixava trancafiada em um minúsculo cômodo do castelo) e a descoberta de novos sentimentos e sensações devido à paixão por Márcio. "BEATRIZ - Oh! Eu gostei muito! Minha mãe, fazes mal em não querer ver daqueles saraus; são cousa maravilhosa. Olha - eu estava à janela à espera de Márcio, quando começou a tocar uma música tão suave, tão doce como nunca igual experimentei. Não sei se chorava! De repente abriu-se a minha porta e a música tangeu estrepitosamente; o resplendor das luzes foi tão forte que me cegou, e ao mesmo tempo entrou pela minha câmara um perfume tão vago, tão agradável, que não como não caí de emoção. Então vi uma cousa mágica, fascinadora. - Eram mil figuras vestidas de mil cores, carregadas de trêmulos, de joias, de brilhantes, que se moviam num círculo rápido e vertiginoso; eu também tinha vertigens porém senti uma mão que prendia a minha mão, e uma voz que me parecia estar falando dentro dos meus ouvidos: Vem — vem!...” DIAS, Gonçalves. Beatriz Cenci. In: Op. Cit., p. 850.

${ }^{492}$ CORREIA, Marlene de Castro. Op. Cit., s/p.
} 
sei, mas inevitável!... Oh! Venha embora o azar maldito, que não será pior que esta ansiedade!... ${ }^{493}$

A ideia de morte está obsessivamente presente: "Houve-me por morta, porém não tive tempo para ter medo. Escrava da minha sorte e sem tentar escapar-lhe, fechei os olhos, senti o zunido de uma cousa que cortava os ares e um braço que enlaçava pela cintura quando ia cair por terra." ${ }^{494}$ Nesse trecho vislumbra-se a ideia de que Leonor não pode fugir à sina de saciar o desejo de vingança do duque, simbolizado em um animal feroz. A presença de Alcoforado parece poder mudar o fado da nobre, mas a força e o poder de d. Jaime a esmagarão, como a fazem perder os sentidos na cena em questão.

No entanto, é interessante notar que o duque tentara reverter a fatalidade que ele prevê: “Sim, Duquesa, estava muito acima da previdência humana, porém, não dos meus pressentimentos." ${ }^{495}$, quando convence a duquesa a voltar para a corte antes mesmo do evento da caçada. A iminência dos fatos, porém, desencadeia a tragédia.

A cena em que o nobre da casa de Bragança persuade a esposa a ir para a corte desvela uma faceta mais humanizada da personagem e evidencia o caráter submisso de Leonor. Compreensivo, d. Jaime se desculpa por seus acessos de cólera e pede para que a mulher reaja de forma mais descontraída diante desses ataques: "O DUQUE - Bem o vejo. Desastrado que eu sou! Mas vós que tanto tempo há me conheceis, por que vos não rides dos meus arrebatamentos, das minhas desconfianças, dos meus acessos de cólera? Por que vos não rides, senhora?"496. Ele também afirma saber que não é o homem ideal para ela: "O DUQUE - Partireis, duquesa; jovem, nobre e formosa, não é com um homem como eu que deveis passar a vida." ${ }^{497}$ Nessa conversa entre o casal, $d$. Jaime antecipa o crime que cometerá contra a esposa quando a compara a uma vítima pronta para ser imolada. Todavia, ele tenta evitar a catástrofe convencendo-a a partir. É interessante notar que a submissão de Leonor, malgrado o contexto em que ela vive e a própria personalidade aguerrida do duque, ajuda a promover o desfecho infeliz. A decisão da partida dá ao público a falsa esperança de um desenlace feliz, configurandose como uma espécie de arco subsidiário de ação.

\footnotetext{
493 DIAS, Gonçalves. Op. Cit., p. 944.

${ }^{494}$ Idem, ibidem, p. 924. Grifos nossos.

${ }^{495}$ Como em todas as falas sobre a caçada, aqui, quando d. Jaime refere-se aos pressentimentos sobre o desastroso ataque do animal feroz, ele alude aos acontecimentos vindouros.

${ }^{496}$ DIAS, Gonçalves. Op. Cit., p. 927.

${ }^{497}$ Idem, ibidem, p. 928.
} 
O DUQUE - Mas não se dirá que sou um esposo colérico e despótico, que entorpeço a vossa vontade, que embargo as vossas ações, que ponho obstáculos aos vossos mais inocentes, mas íntimos desejos? Por Deus, senhora, tende sequer por um instante, sequer uma vez um desejo vosso, uma vontade vossa, livre e independente de outro desejo e de outra vontade. Não vos mostreis como vítima adornada para o sacrifício e levada para ali mau grado seu; mostrai-vos senhora, que realmente o sois. ${ }^{498}$

${ }^{498}$ Idem, ibidem, p. 926. 


\subsection{Sobre o tempo e o espaço}

No que diz respeito à maneira como o espaço é trabalhado em Leonor de Mendonça, diferentemente das outras peças do autor, os objetos cênicos e as ações são funcionalmente aproveitados, como a fita e a caçada que são dados ligados à caracterização temporal e ao mesmo tempo servem como elemento chave para o andamento e o desfecho da peça.

Gonçalves Dias, na prática, define um período de ação que permite ao mesmo tempo variar os lugares de acordo com as exigências da intriga e manter a ficção unitária. A unidade espacial não é, portanto, radicalmente excluída. Dito de outra maneira, Dias deixa claro no Prólogo da peça que opõe o palácio do duque à casa do velho Alcoforado para quebrar a unidade de espaço e inculcar elementos da comédia, perfazendo um drama. No entanto, a modesta residência dos Alcoforado está agregada aos domínios do duque de Bragança, o que atenua a quebra da unidade de lugar e reverbera a subserviência do jovem em relação ao fidalgo.

Para pensarmos o espaço em Leonor de Mendonça, vale lembrar com Malta ${ }^{499}$ que a valorização da ambientação nos romances, sobretudo no final do século XIX, descende dos romances góticos cujas convenções devem provocar suspense e medo. Neles o espaço era mormente representado por castelos medievais, masmorras, escadas e corredores, enfim, lugares sinistros e misteriosos que determinavam, como recursos narrativos, um clima de tensão e uma atmosfera sobrenatural. Dessa forma, o lugar da ação passa a ser tão importante quanto o próprio enredo. Em O Morro dos Ventos Uivantes, de Emily Brontë, por exemplo, a lúgubre propriedade de Wuthering Heights simboliza o conflito e as tormentas que o amor entre Heathcliff e Catherine suscita ${ }^{500}$. Esse tipo de ambientação foi transposto para os romances e dramas históricos, tornandose lugar comum.

Aos poucos, as descrições de castelos e masmorras são substituídas pela representação do ambiente doméstico como um todo, e os mistérios são sucedidos pela exposição da banalidade cotidiana. Valorizam-se as relações sociais domésticas e com elas a relação entre o meio, as personagens e a trama. A exposição do lugar da

\footnotetext{
${ }^{499}$ MALTA, Marize. Entre monstros e bibelôs: histórias extraordinárias de coisas ordinárias. Anais, Rio de Janeiro. XIV Encontro Regional da ANPUH: Memória e Patrimônio, 2010, p. 2.

500 "Wuthering Heights é o nome da residência do Sr. Heathcliff, 'Wuthering' é um provincianismo que descreve o tumulto atmosférico a que este local está sujeito em época de tempestades. E, com efeito, ali em cima deve haver, em qualquer tempo, ventilação pura e salubre.” BRONTË, Emily, Op. Cit, p. 10.
} 
intimidade suscita no leitor um sentimento de identificação e, ao mesmo tempo, de curiosidade.

\begin{abstract}
A correspondência entre objeto e pessoa ocorria em um universo especial: o doméstico - lugar das intimidades, das questões do privado, do campo dos sentimentos e psicologias individuais. Lugar de sonhos [...], onde a ideia de abrigo, de segurança, sobrepunha-se à paisagem caótica do lado de fora. De certo modo, foi na segurança desse espaço de morada, de lugar de dentro, que muitas histórias se fizeram construir, impregnaram imaginações e criaram visualidades próprias no século XIX. ${ }^{501}$
\end{abstract}

Em Leonor de Mendonça paira uma atmosfera gótica no sentido de que o palácio em Vila Viçosa é um lugar fechado, ou melhor, isolado e de difícil acesso. Além disso, o assassinato dos "amantes" reverbera a atmosfera de terror dos romances góticos, pois as personagens não deixam de ser vítimas desse espaço sem saída quando são encurralados no quarto da duquesa. A aflição de Leonor se avoluma nas últimas cenas porque ao fator espaço agrega-se o tempo, isto é, à sensação de enclausuramento se junta a de escoamento do tempo de vida da heroína. Essa dupla pressão cria um efeito onírico, de pesadelo.
A DUQUESA (só, nos degraus do altar) - Não posso orar!... O meu coração não pode despregar-se da vida, minha alma não pode elevar-se até Deus, e a me parece que isto é um sonho! Um sonho horrível que me está sufocando!... (pausa) Tenho frio!... Mas por que aterrar-me assim? ${ }^{502}$
O DUQUE - Findou-se o prazo, senhora.
A DUQUESA - Senhor, mais um instante.
O DUQUE - Mais dez minutos.
A DUQUESA - É pouco, senhor: tenho tanto para vos dizer!
O DUQUE - Tendes um quarto de hora. ${ }^{503}$ religião me não pode consolar!... Quisera ter alguém que me falasse, porque

Vale adicionar que, na literatura gótica, outros ingredientes colaboram para criar uma ambientação de tensão e medo, como o silêncio perturbador, as ventanias, as tempestades, os ruídos e objetos misteriosos. A sensação claustrofóbica imposta por um lugar fechado ou labiríntico bem como a natureza sombria e misteriosa provocam ansiedade nas personagens, as quais mormente apresentam estados emocionais

\footnotetext{
${ }^{501}$ MALTA, Marize. Op. Cit., p. 2.

502 DIAS, Gonçalves. Op. Cit., p. 957.

${ }^{503}$ Idem, ibidem, p. 963.
} 
condizentes com o espaço, apresentando-se melancólicas, amedrontadas, ou desequilibradas.

$\mathrm{Na}$ peça em questão, o clima de tensão vai sendo construído desde o início do drama. Já no I Ato, após o episódio da caçada, d. Jaime vaticina o desfecho cruel, pressentindo para a vítima um fim inevitável. Mas é no II Ato que essa ansiedade alcança seu clímax. Os pressentimentos se recrudescem, a noite se adensa escura e feia, os dobres do dia de finados ressoam agravando a angústia do jovem Alcoforado. Por sua vez, no palácio, o duque prevê as tempestades e evoca: "Oh! Venha embora o azar maldito, que não será pior que esta ansiedade!...."504

Na peça, há uma insistência em associar a noite com angústia e terror, pois a véspera já havia sido aflitiva para o duque e a duquesa. Ambos haviam dormido mal rememorando suas lembranças e dissabores. Além disso, a repetição da ideia de obscuridade da noite coadunada com a de horror ${ }^{505}$ não coopera apenas com a descrição do espaço/tempo, mas remete também à imensidão. Burke assinala que a falta de visibilidade no escuro incapacita-nos de conhecer a dimensão do perigo vindouro, fazendo avolumar o nosso medo. Assim, o escuro torna a ameaça imensurável e muito mais assustadora do que a descrição minuciosa do mal ${ }^{506}$.

É interessante observar que, segundo Halsall, no teatro hugoano o espaço interage com as personagens e revela as pretensões, maquinações e perfídias que envolvem a trama, perfazendo-se em ambientes misteriosos, tortuosos e angustiantes:

\footnotetext{
Hugo was partial to a décor of hidden passages, reversal of on-stage and offstage events, and above all to a dynamic interaction between character and stage setting. Setting participates in dramatic action. Thus 'local colour' should not only convince us of the historical period and place, it should also reveal the motives, lusts, ambitions of the inhabitants. Angelo's palace, with its secrets passages, hidden doors and wall cavities admirably suggests the atmosphere of intrigue and violent double-dealing that Padua's podesta maintains $\mathrm{n}$ order to keep his power. ${ }^{507}$
}

O palácio ducal e a casa de Alcoforado em Leonor de Mendonça, considerando as diferenças e aproximações com o teatro de Hugo, podem ser analisados abarcando o significado que esses elementos góticos assumem.

\footnotetext{
${ }^{504}$ Idem, ibidem, p. 944.

505 “ALCOFORADO - A noite vai escura e feia!"; "ALCOFORADO - O céu está coberto de nuvens; a noite vai escura e medonha!" Idem, ibidem, p. 935 e 936 respectivamente.

506 "Para tornar algo extremamente terrível a obscuridade parece ser, em geral, necessária. Quando temos conhecimento de toda a extensão de um perigo quando conseguimos que nossos olhos a ele se acostumem boa parte da apreensão desaparece." BURKE, Edmund. Op. Cit., p. 68.

${ }^{507}$ HALSALL, Albert W. Op. Cit., p. 147.
} 
Em relação aos elementos cênicos, Anne Ubersfeld distingue três tipos de valores conferidos aos objetos nos melodramas e dramas românticos. A primeira função é utilitária, contribuindo para o desenvolvimento do entrecho. O segundo possui função histórica ou pitoresca, contextualizando a ação. A terceira é simbólica, objetos como máscaras, venenos e chaves, por exemplo, representam a violência do Estado. A autora assinala que no teatro de Hugo predominam os objetos com função simbólica. Na obra de Dumas, eles são dramaticamente empregados, funcionando como agentes de ação. Esses valores inerentes aos objetos podem sobrepor-se e adquirir mais de uma função ${ }^{508}$. Esse é o caso de Leonor de Mendonça em que os objetos condensam, geralmente, uma função dramática e histórica e, em alguns casos, simbólica também.

Relembre-se que na Cena II do primeiro Ato, Paula conta à duquesa que o jovem cavaleiro havia cortado um pedaço da fita da nobre sem que ela pudesse detê-lo. Leonor a repreende, lembrando-lhe que todos já a tinham visto com aquele adorno e que o duque poderia ficar muito zangado se notasse que o objeto estava em poder do mancebo. Paula, que já conhecia a paixão do rapaz pela sua senhora, tenta demovê-la da preocupação, afiançando que Antônio Alcoforado pensava que a fita fosse da própria camarista. A duquesa parece ficar um pouco mais aliviada e pede-lhe que retome a fita. $\mathrm{Na}$ IV Cena do mesmo ato, em uma conversa que trava com o jovem, a própria Leonor toma a fita de volta, mas, em seguida, entrega-lhe novamente como uma memória, pois decide que Alcoforado servirá nas lides de d. Manuel. Será essa fita uma das supostas provas de adultério para o duque, quando o nobre a encontra amarrada no barrete do rapaz. O objeto, portanto, assume um valor utilitário no entrecho.

Segundo Correia ${ }^{509}$, a fita simboliza o laço amoroso entre Leonor e Alcoforado. $\mathrm{Na}$ Cena IV do Ato I (Quadro I) em que Leonor pede a fita de volta e a entrega novamente ao jovem, quando se arma o jogo de sedução "sinuoso" 510 , esse objeto adquire mais um sentido, o da ambiguidade dos sentimentos de Leonor. Além da fita, a duquesa concede ao jovem uma entrevista. Ambas as concessões remetem às regras do amor cortesão adquirindo no drama um valor histórico.

De acordo com os preceitos do amor cortês, o mancebo submete-se à amada sendo-lhe fiel e prestando-lhe serviços que mostram seu valor e sua coragem. O amor puro e a dedicação mereceriam a piedade e algumas recompensas da senhora. Dessa

\footnotetext{
${ }^{508}$ UBERSFELD, Anne apud NAUGRETTE, Florence. Op. Cit., 2001, p. 262-263.

${ }^{509}$ CORREIA, Marlene de Castro. Op. Cit.

${ }^{510}$ Idem, ibidem.
} 
forma, a dama era obrigada a conceder favores ao cavaleiro, caso fossem razoáveis. No entanto, vale mencionar que a atitude de Leonor, apesar de ela negar qualquer deslize, seria condenável aos olhos da sociedade coetânea de Gonçalves Dias, pois o flerte era considerado uma falta grave ${ }^{511}$. Por outro lado, Leonor assume, em grande medida, características consideradas ideias pela sociedade burguesa:

\footnotetext{
Da mesma forma, se você descreve uma mulher correta, num sentido elogioso, ela deve ter uma gentil suavidade, um medo brando, e todas aquelas partes da vida que a distinguem do outro sexo, com alguma subordinação, mas que seja de tal inferioridade que a torne ainda mais adorável. ${ }^{512}$
}

No drama também se vislumbra na figura da protagonista e em Laura, irmã de Alcoforado, os quatro papéis sociais que, no século XIX, circunscrevem-se à mulher: $\mathrm{o}$ papel de filha, irmã, esposa e mãe: 'Tudo o que ela tem a fazer neste mundo está contido nos deveres de filha, irmã, esposa e mãe. ${ }^{513}$

E, por fim, em relação à fita, é preciso lembrar ainda que ela apropria-se do motivo do lenço de Desdêmona, assumindo os significados inerentes à intertextualidade com o texto shakespeariano: objeto que serve como recurso de desencadeamento da cólera dos maridos supostamente traídos.

A caçada funciona como uma espécie de peripécia do drama, pois se a duquesa não tivesse participado da batida, o episódio do javali e o socorro que Alcoforado the presta tampouco ocorreriam. A caçada é a propulsora da imprudência da duquesa e da tragédia final (função dramática).

Vale lembrar que a caça tornou-se um privilégio da nobreza europeia a partir do século IX, e o desrespeito a esse direito era severamente punido ${ }^{514}$. Havia duas modalidades de caça, a de montaria e a de cetraria ${ }^{515}$. A primeira era feita a cavalo em campo fechado, isto é, em uma floresta. Consistia numa forma de divertimento e, ao mesmo tempo, de treinamento para a guerra. A segunda modalidade era considerada apenas um tipo de recreação, feita em campo aberto, pois não exigia tanto esforço físico como a montaria. Por isso as mulheres dela podiam participar.

511 VASCONCELOS, Sandra Guardini Teixeira. Op. Cit., 2007, p. 129.

512 THE SPECTATOR, n. 144, 2:70 apud VASCONCELOS, Sandra Guardini Teixeira. Op. Cit., 2007, p. 131.

${ }^{513}$ STEELE, Richard apud VASCONCELOS, Sandra Guardini Teixeira. Op. Cit., 2007, p. 131 -132.

${ }^{514}$ GUERREAU, Alain. Caça. Trad. Vivian Coutinho de Almeida. In: LE GOFF, Jacques; SCHIMITT, Jean-Claude (Coord.). Dicionário Temático do Ocidente Medieval. Coord. de tradução Hilário Franco Junior. Bauru, SP: EDUSC; São Paulo, SP: Imprensa Oficial do Estado, 2002, vol. I, p. 140-141.

515 MONGELLI, Lênia Marcia (Coord.). A literatura doutrinária na corte de Avis. São Paulo: Martins Fontes, 2001, p. 160. 
Na peça em questão, há uma junção das duas modalidades visto que há o uso de montaria e de aves de rapina. A caçada simboliza, ao mesmo tempo, a soberania e a violência de d. Jaime, e o heroísmo altruísta de Antônio Alcoforado. Ademais, o exercício de caça acontece num espaço aberto, contrário ao espaço doméstico. Vale mencionar que, considerando o tempo da enunciação, a mulher estava circunscrita ao ambiente do lar e o espaço público era destinado aos homens. Assim, quando a duquesa ultrapassa o limite do privado, ela é exposta ao perigo e sua vida é posta em risco.

\begin{abstract}
Increasingly throughout the eighteenth century, the interrelated categories of masculine and feminine, public and private, home and 'world', assumed the shape of binary oppositions in which the meaning of each category was produced in terms of its opposite. Gender was constructed through the naturalizing of this system of oppositions; women were represented as naturally possessing qualities that rendered them with considerable authority within the private context of the home. ${ }^{516}$
\end{abstract}

Correia ${ }^{517}$ também chama atenção para o ato de toucar, relacionado à duquesa, $\mathrm{A}$ atividade que assume a função simbólica de juventude, galanteria, beleza e vida é contraposta ao altar paramentado apresentado no final da peça, o qual remete ao sacrifício e à "santidade" de Leonor. A propósito, Matos evoca nuances significativas sobre o toucador. Boudoir em francês, ele é o lugar para onde as pessoas se retiram para bouder, isto é, demonstrar descontentamento e aborrecimento. Mas é também o lugar onde as mulheres se arrumam, se penteiam e se maquiam. Nesse sentido, o toucador é um local ambíguo, pois nele se ajustam e se deixam cair as máscaras, o que lhe confere um cunho teatral ${ }^{518}$. Em Leonor, o jogo de máscaras entre as personagens que agem de acordo com as regras sociais, mas sentem e pensam de forma diferente, perfaz-se de forma metafórica na cena do boudoir. A duquesa mostra a sua intrínseca preocupação com a imagem e, ao mesmo tempo, revela ao leitor/espectador as suas insatisfações.

Os objetos cênicos e os eventos da peça, como os dos exemplos acima, além de conferirem uma atmosfera condizente com o tempo e o espaço do drama, Portugal do século XVI, complementam a trama ao invés de apenas colorir a cena. A fita, a entrevista e a caçada são essenciais ao desfecho. De acordo com as tendências do drama

\footnotetext{
${ }^{516}$ SHEVELOW, Kathryn. Women and Print Culture apud VASCONCELOS, Sandra Guardini Teixeira. Op. Cit., 2007, p. 128-129.

${ }^{517}$ CORREIA, Marlene de Castro. Op. Cit.

${ }^{518}$ MATOS, Franklin de. Libertinagem e Despotismo. In: Op. Cit., 2001, p. 217.
} 
romântico, sobretudo o de cunho histórico, Gonçalves Dias busca no espaço e tempo inexplorados pelo teatro clássico a matéria para o enredo.

A significação do espaço também é construída por meio da estruturação da peça em quadros. Segundo Diderot, o tableau sintetiza o significado e o sentimento de uma determinada cena ou ato. Como para o filósofo o escopo principal do teatro é sensibilizar a plateia, seja através da pantomima, do gesto ou dos quadros, o espetáculo, deve ser entendido também como aparência, não apenas como declamação verbal. ${ }^{519} \mathrm{~A}$ função do quadro ${ }^{520}$ é, portanto, potencializar o discurso, ${ }^{521}$ tornando-o mais poético pela concentração de significados que reúne.

Outrossim, o acúmulo de lances teatrais são contrapostos aos tableaux nas "Conversas sobre o filho natural" por prejudicarem a verossimilhança, pois, segundo o filósofo, o gênero dramático deve dar preferência às ações simples e de fácil imitação. Para Diderot, o drama assim como a pintura, lida com uma temporalidade concentrada e, por isso, a representação deve preferir quadros ao acúmulo de acontecimentos imprevistos. Essa noção em Diderot implica ainda a quebra da cláusula dos estados, pois ela serve para mostrar a natureza humana, independentemente da condição social da personagem. Nesse sentido, nas "Conversas", Diderot oferece dois exemplos que confirmam essa relação: o da rainha Clitemnestra, que se desespera com o sacrifício da filha e o da camponesa que chora o assassinato do marido ${ }^{522}$.

A divisão em quadros também é uma característica do melodrama romântico, mas significando a rápida troca de cenários que o desenvolvimento técnico permitiu. $\mathrm{O}$ método era utilizado principalmente nos dramas baseados em romances. Os planos cênicos rememoravam ao espectador o trecho correspondente ao da narrativa. Por conta dessa relação com o folhetim, os melodramas aumentaram a sua extensão, organizandose em cinco atos em vez de três.

Nos dramas românticos a distinção entre atos e quadros tende a se enfraquecer como atestam as obras de Victor Hugo e de Musset ${ }^{523}$. Vale lembrar que, comumente, o

\footnotetext{
${ }^{519}$ DIDEROT, Denis. Op. Cit., 2005, p. 49.

${ }^{520}$ Diderot define quadro a partir da oposição com lance teatral: "Um incidente imprevisto que se passa na ação, mudando subitamente o estado dos personagens, é um lance teatral. Uma disposição destes personagens em cena, tão natural e verdadeira que, fielmente representada por um pintor, agradaria sobre a tela, é um quadro.” DIDEROT, Denis. Op. Cit.,, 2008, p. 107.

${ }^{521}$ MATTOS, Franklin de. A querela do teatro no século XVIII: Voltaire, Diderot, Rousseau. O que nos faz pensar. Rio de Janeiro: Departamento de Filosofia, PUCRJ, v. 25, ago. 2009, p. 7-22.

522 Idem. A dramaturgia do quadro. Discurso. São Paulo: Departamento de Filosofia da FFLCH da USP, v. 26, 1996, p. 93-112.

${ }^{523}$ UBERSFELD, Anne. Op. Cit., 2005, p. 143.
} 
tableau é entendido como uma divisão fundada sobre uma mudança do espaço ou do espaço-tempo.

No caso de Gonçalves Dias, deu-se justamente o contrário. Leonor de Mendonça é a única peça do autor condensada em três atos. O primeiro e o segundo ato contêm dois quadros, e o segundo, apenas um. Os quadros são subdivididos em cenas, totalizando nove para cada um, com exceção do Quadro IV, constituído de sete cenas. É preciso analisar a divisão proposta em Leonor de Mendonça para compreender qual a noção de tableau adotada pelo autor. Essas subdivisões na peça são acompanhadas por didascálias que descrevem o espaço e o cenário. No primeiro e segundo quadro tem-se uma sala com toucador, o terceiro apresenta uma sala modesta em casa do velho Alcoforado, o quarto, a câmara da Duquesa, e o último exibe um aposento no palácio do duque onde há um altar do lado direito. Embora a peça seja dividida em três atos, cinco quadros delimitam os acontecimentos mais importantes da peça, o espaço pode permanecer o mesmo, como no caso do primeiro ato. Nesse sentido, essa subdivisão em Leonor de Mendonça tem uma função estrutural em relação às ações e ao espaço-tempo.

No entanto, eles também sintetizam sentidos como propõe Diderot. O primeiro e o segundo tableaux apresentam um espaço e objetos cênicos que representam a domínio da duquesa e sinalizam a beleza, a juventude e a clausura que a envolvem. O terceiro é importante, pois introduz outro espaço com todos os significados que lhes são inerentes: a modesta sala em casa do velho Alcoforado. O quadro íntimo de uma família, modesta, unida e terna contrapõe-se à riqueza, solidão e severidade presentes no palácio do duque. O quarto retoma o espaço do palácio e rememora a primeira cena da peça em que Paula já fizera as primeiras premonições negativas sobre o interesse do jovem Alcoforado pela duquesa. Na última subdivisão, o altar paramentado é bastante significativo como espaço em que se desenrolam a confissão, o desespero e a afirmação do assassinato da nobre.

A imagem do crucifixo sobre o altar intensifica a sujeição de Leonor à fatalidade, não obstante a sua inocência. A primeira cena do quadro assinala a solidão e o desamparo da duquesa, pois nem mesmo a Providência interfere a seu favor. Aqui, como em Schiller, as questões religiosas não são colocadas em primeiro plano, privilegia-se a ótica moral e social ${ }^{524}$. A inserção de uma esperança na imortalidade num

524 HARTMANN, Pierre. Du sublime: de Boileau à Schiller. Strasbourg: Presses Universitaires de Strasbourg, 1997, p. 92. 
sentido religioso daria à Leonor certa segurança e isso mitigaria o efeito trágico e a crítica social que o assassinato da duquesa implica.

\begin{abstract}
Essa ideia de imortalidade, na qual a sensibilidade de certo modo ainda é levada em conta (tal como é estabelecida em todas as religiões positivas), não pode contribuir em nada para fazer da representação da morte um objeto sublime. Antes, tem essa ideia de permanecer somente em segundo plano, de modo a apenas vir em auxílio da sensibilidade caso esta se sinta exposta, sem defesa ou conforto, a todos os terrores do aniquilamento e corresse o risco de sucumbir a esse ataque veemente. Se essa ideia da imortalidade se torna dominante no ânimo, a morte perde o temível, e o sublime desaparece. ${ }^{525}$
\end{abstract}

Ainda sobre o espaço, vale mais uma vez ressaltar a tensão entre os dois sítios: o palácio ducal de Vila Viçosa e a casa do jovem Alcoforado. Os espaços em Leonor de Mendonça têm valor simbólico, como no teatro de Victor Hugo. Anne Ubersfeld mostra que os dramas hugoanos são estruturados por uma oposição entre o espaço do poder, fechado e protegido (espaço A) ${ }^{526}$, e o espaço da marginalidade (espaço não-A ou B). As personagens do espaço do poder têm uma função, um nome e uma classe definidos $^{527}$. Os caracteres do outro ambiente não têm uma categoria social determinada, sua condição se estabelece pelo conflito com a figura socialmente dominante. Não há integração entre esses dois espaços, e toda personagem do espaço B que penetra no espaço do poder paga sua transgressão com a morte, já que o caracter principal do espaço A detém o poder de matar.

\begin{abstract}
Nos comprenons comment l'anthithèse est une figure-clé de l'écriture hugolienne. Dans le théâtre, elle prend cet aspect particulier de deux espaces don't l'un est l'envers de l'autre, mais qui sont tout presents, inséparablement, dans l'oeuvre; tantôt comme Castor et Pollux, l'un visible quand l'autre est caché, l'un en coulisse quand l'autre est sur scène, tantôt, au contraire, s'afrontant sous les espèces de deux personnages. ${ }^{528}$
\end{abstract}

Diferentemente da tradição clássica em que os gêneros têm um espaço distinto, ou seja, a tragédia representa o espaço fechado e a comédia, o espaço aberto, nos dramas românticos, o espaço particular é privilegiado. No entanto, há uma tensão entre o que é particular e o que é social. O movimento dramático sobrevém do embate entre

\footnotetext{
525 SCHILLER, Friedrich. Op. Cit., 2011, p. 35.

${ }^{526}$ Ubersfeld retifica que a noção de passagem de um espaço para outro presente no teatro de Hugo é essencial para os dramas românticos em geral.

${ }^{527}$ O espaço A é o lugar: “- du Roi et par là du Pouvoir (ministres, etc.) (signes:, or clefs), - des privilégiés, aristocratiques (fête, blason), - de la justice répressive (prison, échafaud, bourreau, etc.), - de la séduction opressive des femmes (Don Juan...), - de tout ce que appartient à la ordre du passé." UBERSFELD, Anne. Op. Cit., p. 453.

${ }^{528}$ Idem, ibidem, p. 410.
} 
os desejos das personagens com as leis inflexíveis inerentes ao espaço social, as quais podem ser explícitas ou sutis.

Na peça em questão, o palácio ducal simboliza esse ambiente fechado que é invadido pelo modesto ascendente a cavaleiro, o qual pagará com a morte a sua ousadia. É pertinente mencionar que a condição de Antônio Alcoforado ainda não está consolidada. Jovem ${ }^{529}$, ele ainda não cingiu espada de cavaleiro e sua família não é socialmente representativa. A duquesa que abre as portas para o espaço do poder também é punida.

De acordo com o esquema sugerido por Ubersfeld para o teatro hugoano, Alcoforado tenta se mover para o espaço A por conta do amor que sente por Leonor, cuja falta é ajuda-lo na tentativa dessa passagem. A casa de Alcoforado, conforme mencionado anteriormente, é modesta, e as relações da família que a habita são movidas pela afetividade, embora prevaleça a autoridade paterna, e predominem os valores burgueses ${ }^{530}$. Além das duas casas, há o local aberto da caçada que não é efetivamente um espaço cênico porque é um episódio narrado no drama. Mas é interessante notar que é nesse ambiente aberto que surge a oportunidade para Alcoforado ser convidado a adentrar o lugar do poder.

Ubersfeld também pontua que em Dumas e Hugo essa oposição espacial revela a ideologia liberal do progresso. As personagens do espaço B, os não integrados, representam o "Bem Moral", mas são impedidos pela sociedade de se integrar aos postos mais altos de A, a sua posição, o seio de sua família e de sua cultura. O futuro e o progresso permitirão aos heróis de $\mathrm{B}$ encontrar o lugar correspondente aos seus talentos e méritos, à pureza de seus corações ${ }^{531}$. Por meio de suas personagens, Victor Hugo representa "a grandeza que se abaixa e a pequenez que se eleva a ponto de se cruzarem". ${ }^{532}$ Note-se como essa assertiva do dramaturgo francês vai ao encontro da descrição que Dias faz da personagem que representa os não integrados, Antônio

\footnotetext{
${ }^{529}$ No Prólogo da peça, Gonçalves Dias explica que as características de Antônio Alcoforado se devem à idade e que são esses atributos que guiam suas ações: "Antônio Alcoforado é o que ele devia ser na sua idade, corajoso e dedicado; dedicado, por que a benevolência da duquesa em favor dele se convertesse em gratidão; corajoso, para ter o direito de morrer sem defender-se, para que pudesse suplicar sem baixeza, mas antes nunca maior nem mais nobre do que quando curvado pedisse justiça para a mulher que não pudesse defender, e piedade para a que não pudesse salvar." DIAS, Gonçalves. Prólogo a Leonor de Mendonça. Op. Cit., p. 906.

530 "Na família dos Alcoforado [Gonçalves Dias] quer mostrar a força e a beleza das virtudes burguesas; sublinha 'o contraste entre o duque poderoso e o modesto pai de família, entre o palácio suntuoso e a habitação singela."” JACOBBI, Ruggero, Op. Cit., p. 77.

${ }^{531}$ UBERSFELD, Anne. Op. Cit., p. 455.

532 PRADO, Décio de Almeida. Op. Cit., p. 40-41.
} 
Alcoforado. Ele, apesar de corajoso, não hesita em se desfazer de sua espada, cumprindo a promessa que fizera a Leonor. Demonstrando sua nobreza de caráter, o jovem se submete à ignomínia e à morte para salvar a duquesa.

\begin{abstract}
ALCOFORADO - Ainda quando a mentira houvesse escolhido os meus lábios para sua morada, não vos mentiria eu no meu derradeiro instante para que a maldição divina não pesasse eternamente sobre a minha alma. Não é por mim que vos suplico a vida, Sr. Duque; fora indigno de viver quem tão baixamente a suplicasse. Estou no vosso poder, nem disso me queixo; depus a minha espada a vossos pés antes que me viesse a tentação de a arrancar contra vós; curvei a cabeça na vossa presença, e de joelhos e à hora da morte eu vos digo que ela é inocente, que por isso me tenho envilecido, e que por isso me envileço ainda. ${ }^{533}$
\end{abstract}

Observe-se que, depois dessa fala de Alcoforado, a duquesa, à parte, exclama: "Nobre mancebo!". Essa frase se contrapõe a outra que ela havia dito ao marido na Cena V desse mesmo ato, quando ela questiona a superioridade social e, principalmente, moral do duque: "É isto ser nobre?". Adiante, Leonor novamente contestará a honra de d. Jaime, relacionada ao sentido de poder e autoridade, que se mostra, na verdade, arbitrária e injusta:

\begin{abstract}
A DUQUESA: - Sr. Duque, vós sois poderoso e escusais de subterfúgios contra mim. Ninguém vos pedirá contas da minha morte, senhor, e escusais de torcer os vossos juízos para me caluniar. Podeis dizer, e dizei-o francamente, que ninguém nos escuta: 'Morrerás porque assim o quero!' É uma razão que todos compreendem, a razão do mais forte, se não é a do mais nobre. Contra a vossa vontade me oferecestes mão de esposo, e tendes sempre vivido constrangido considerando-me como um estorvo para a vossa vocação, porque premeditáveis ser frade ou cousa semelhante. Bem oportunamente vos sorri este ensejo para de mim o desfazerdes. Aproveitaivos dele, e agradecei ao azar sem ostentardes de justiceiro. Não me faleis em justiça humana, senhor, porque eu me poderei lembrar que vosso pai foi humanamente justiçado! 534
\end{abstract}

Essa fala de Leonor é bastante sintomática. Remete às ideias relativas aos princípios da ação, expostas no prólogo, de que o embate entre os caracteres não poderia ter um desfecho diferente, pois as circunstâncias histórico-sociais promovem a vitória do forte sobre o fraco. No entanto, a vitória do mais poderoso sobre os desprivilegiados é injusta.

${ }^{533}$ DIAS, Gonçalves. Op. Cit., p. 955.
${ }^{534}$ Idem, ibidem, p. 964. 
Voltando à questão especificamente espacial e recordando que as narrativas dramáticas tendem a representar um conflito de espaços ${ }^{535}$, pode-se dizer que na tentativa de conquistar o lugar da nobreza, Alcoforado obtém algumas vitórias antes de ser derrotado. Logo no primeiro ato do drama, o jovem adentra a sala do toucador para falar a sós com a duquesa, infringindo a etiqueta cortesã, pois não fora chamado, anunciado e nem mesmo convidado. Contrariamente, o duque manda um pajem perguntar se Leonor poderia recebê-lo. Dessa maneira, há uma inversão de lugares. Para se ter uma ideia da dimensão do atrevimento do jovem cavaleiro e da imprudência da duquesa, basta comparar como a entrada de Alcoforado sem ser anunciado provoca a ira do duque na Cena V do Quadro II: “(...) Quem ousa interromper-nos?”. Ele interpreta a ação de Antônio como uma afronta e mostra-se bastante severo até que Leonor esclarece a situação, advertindo o marido que Alcoforado havia sido chamado pelo próprio duque. Note-se que, na percepção do nobre, é preciso cumprir as regras de etiqueta. Além das falas, as didascálias colaboram para demonstrar que à superioridade social se coaduna a violência ${ }^{536}$ quando destacam a severidade do duque de Bragança e a sua impetuosidade ao levantar-se no momento em que ameaça o jovem.

O DUQUE (levantando-se) - Mancebo, não costumamos a repetir as nossas ordens. Cabeças mais nobres, presunções mais bem fundadas que as vossas, nós a temos por mais de uma vez curvado até se nivelarem com o solo. Rompei o silêncio, senhor, ou por S. Tiago... 537

No entanto, no início da cena, Alcoforado responde de maneira afrontosa demonstrando orgulho e arrogância. Por fim, Antônio e Leonor são punidos quando o jovem penetra no aposento da duquesa. Para d. Jaime a boa ação de Alcoforado salvando a vida de Leonor fora um subterfúgio para que ele pudesse conquistar o espaço de sua casa, seus servos e a esposa. Na fala a seguir é possível observar como a ideia de dominação do espaço e da tentativa de usurpação do poder estão interligadas na percepção do duque:

O DUQUE - Silêncio! Que mostrastes vós? Que já na vossa idade tendes a astúcia de uma serpente: e de feito, tendes enganado a todos com falsas aparências de nobreza e de candura; mendigastes a minha proteção,

${ }^{535}$ UBERSFELD, Anne, Op. Cit., 2005, p. 106.

${ }^{536}$ A violência do duque é sempre ressaltada e contraposta à gentileza de Alcoforado. Até mesmo a descrição de como andam a cavalo marca essa diferença.

${ }^{537}$ Idem, ibidem, p. 928. 
introduzistes-vos em minha casa, aliciastes meus servos, seduzistes minha... nem eu sei como a chame!... Morrerão ambos! ${ }^{538}$

Além do sentido de contraposição, o espaço em L.M. manifesta uma acepção de negatividade, já que o casal de duques não deseja estar nesse lugar. Relembre-se que a duquesa gostaria de retornar à corte, porque as terras pequenas, desprovidas de atividades de entretenimento, fazem-na perder o sono. E Paula a adverte de que as noites mal dormidas lhes podem ser prejudiciais. Esse diálogo que marca a entrada de Leonor em cena, adianta ao leitor/espectador tanto a rechaça do espaço por parte da personagem como a premonição da morte vindoura. Mais uma vez Gonçalves Dias está jogando com ambiguidades. A falta de diversão provoca tédio na protagonista, além disso, a ida à Vila Viçosa reafirma a distância entre ela e o marido, apesar de permanecerem juntos no mesmo sítio. Esse contexto impulsiona a fatal aproximação entre ela e o jovem Alcoforado. Desse modo, a fala de Paula parece ir além do sentido literal, relacionando os problemas conjugais de d. Jaime e Leonor de Mendonça ao espaço, Vila Viçosa, e a tragédia futura.

\begin{abstract}
A DUQUESA - Não pude dormir; assim me acontece em terras pequenas. Não tenho em que empregar serões, deito-me cedo, e passo a noite a revolver-me no leito.

PAULA - Como estais pálida! Realmente é-nos preciso ir para a corte quanto antes; que se passais muitas noites como esta, não vos asseguro a vida por um ceitil. $^{539}$
\end{abstract}

Do mesmo modo, a desvalorização do espaço pelo duque é expressa na primeira cena em que atua ${ }^{540}$. Embora prefira Vila Viçosa à corte, ele só sente prazer e paz quando se isola para se dedicar à religião na Serra de Ossa ou em seu oratório.

O DUQUE - Não imaginais com que profundo prazer parto sempre para viver uma semana na Serra de Ossa com os meus capelães, alimentando-me com a doutrina daqueles santos padres, ou exercendo as práticas mais severas da sua religião; ou então, e bem melhor, para habitar o meu oratório no Convento do Bosque. O meu oratório, sabeis o que é? Uma ermidazinha humilde e vergonhosa ali escondida entre as ramas do arvoredo frondoso

\footnotetext{
${ }^{538}$ Idem, ibidem, p. 955.

${ }^{539}$ Idem, ibidem, p. 913.

540 "Vogler diz que 'a primeira ação do personagem é uma magnífica oportunidade para informar uma porção de coisas sobre a atitude, estado emocional, contexto, forças e problemas' VOGLER, Christopher. A jornada do escritor: estruturas míticas para escritores. Trad. de Ana Maria Machado. 2. ed. Rio de Janeiro: Nova Fronteira; Sinergia; Ediouro, 2009 apud ALMEIDA, Rafael Loureiro de. Martins Pena: narrativas e arquétipos do teatro romântico brasileiro. Rio de Janeiro, 2012, Dissertação de mestrado. Programa de pós-graduação em Letras Vernáculas. Universidade Federal do Rio de Janeiro, p. 102.
} 
como um pensamento de virgem, aformoseado pelo silêncio e pelo pudor. Os pensamentos que aqui me perseguem, dolorosos como a realidade, lá me aparecem doces e tristes como uma recordação. ${ }^{541}$

Em relação ao tempo, Correia observa que a sua excelente manipulação evidencia as qualidades estruturais da peça. Como é sabido, Leonor de Mendonça é condensada em três atos em vez de cinco atos. Em suas três partes, os diálogos, "os arcos subsidiários de ação" e os signos aziagos prendem a atenção do leitor/espectador em relação aos sentimentos e ao destino da protagonista. No terceiro ato, por exemplo, o ritmo dramático acelera-se em consequência do suspense que as oscilações de Leonor imprimem ao drama. Ela passa da confiança no perdão ao descrédito, da resignação subserviente à rebeldia altiva. A certeza do desfecho é adiada por meio de "arcos subsidiários de ação", como a confissão de Leonor, a recusa do servo em executar a duquesa e a tentativa do duque de persuadir os outros empregados para que a assassinem. Todos esses fatos adiam a execução da nobre e despertam a esperança em Leonor e no público.

Sobre o quadro temporal em Leonor de Mendonça também é interessante notar a importância dos índices de passado impressos nas micronarrativas. Elas referem-se a acontecimentos extracênicos, essenciais para o desenvolvimento da ação e a composição das personagens ${ }^{542}$. As micronarrativas informam sobre o passado das personagens, principalmente, sobre o casal de duques. É interessante notar que essas sequências informativas elucidam por que d. Jaime e Leonor não são felizes e como essa condição se deve ao fato de serem nobres, e, portanto, submetidos às regras e as vicissitudes da sociedade de corte cuja dinâmica se baseia no jogo de interesses. A narração da morte do pai de d. Jaime torna-se um exemplo dessas instabilidades, pois antes da subida de d. João II ao trono, em 1481, o $3^{\circ}$ duque de Bragança detinha grande poder e influência sobre o trono. Outro episódio, narrado por Leonor, refere-se à imposição do casamento com d. Jaime e como essa decisão afetou a sua infância e felicidade. Essas sequências narrativas sobre as personagens contribuem para delinear uma visão negativa das disposições de corte que, ademais, podem ser contrapostas à vivência das personagens mais modestas.

Note-se que os fatos históricos aludidos em L.M., diferentemente do que acontece em outras peças gonçalvinas, se integram à composição das personagens e não

\footnotetext{
${ }^{541}$ DIAS, Gonçalves. Op. Cit., p. 921.

${ }^{542}$ UBERSFELD, Anne. Op. Cit., 2005, p. 138.
} 
destoam da ação. Isso se dá porque esses episódios são sempre encarados de forma subjetiva pelas personagens, seja no caso de grandes acontecimentos como o julgamento de d. Fernando e o desterro de d. Jaime em Castela, seja na referência à concessão dos dízimos do pescado em Lisboa e terras ao duque como forma de compensação pelos sofrimentos causados à casa de Bragança (Ato II, Quadro Terceiro, Cena VIII). 


\title{
3.9. Leonor de Mendonça no contexto teatral brasileiro oitocentista
}

Para melhor compreender a importância de Leonor de Mendonça, deve-se ter em conta que, entre os anos de 1840 e 1850 do século XIX, o melodrama e a ópera eram os gêneros teatrais mais populares no Brasil. Além disso, a comédia, representada pelos vaudevilles franceses, e a comédia de costumes, sobretudo as de Martins Pena, eram bastante encenadas. Assim como Gonçalves Dias conseguira fazer vingar o romantismo na poesia brasileira, pensava ele difundir o drama romântico, mas as suas peças não lograram êxito. Relembre-se que, ao retornar de Portugal, Gonçalves Dias já havia escrito dois dramas, Patkull e Beatriz Cenci. E em 1846, no Rio de Janeiro, escreve Leonor de Mendonça. Essas obras, assim como o Prólogo de Leonor de Mendonça, demonstram que ele conhecia os dramas franceses, o teatro alemão e a tragédia shakespeariana, bem como as obras neoclássicas.

\begin{abstract}
A hegemonia do melodrama na cena brasileira dos tempos românticos, graças a João Caetano, talvez explique algumas das dificuldades enfrentadas pelos dramas românticos para se fazerem aceitos. Gênero que simplifica os sentimentos, que vê o ser humano pela ótica maniqueísta e que ao final pune os culpados e premia os virtuosos, o melodrama conquistou enorme prestígio popular. Já o drama romântico, com maior preocupação literária, com personagens complexos, muitas vezes trazendo dentro de si o bem e o mal, e com temas controvertidos, como o incesto e o adultério, enfrentou a ira dos moralistas e, não conquistando a cena, não teve adeptos entre 1836 e $1845 .^{543}$
\end{abstract}

Gonçalves de Magalhães, por exemplo, a despeito de ter escrito a primeira tragédia nacional, encenada por uma companhia profissional brasileira, não aderiu totalmente às novidades do teatro romântico. Talvez por escolher uma personagem "brasileira" em Antonio José, suas tragédias tiveram melhor sorte que os dramas gonçalvinos, pois ambas, Antônio José e Olgiato, foram à cena pela companhia de João Caetano.

Conforme foi comentado acima, as concessões à tragédia clássica em Leonor de Mendonça colaboraram para o efeito trágico e excelência da obra. Já em Magalhães, a estrutura baseada na tragédia destoa da temática assumida. Em Antonio José ou O Poeta e a Inquisição, por exemplo, a escolha do tema deveu-se à intenção de abarcar um assunto nacional ao teatro brasileiro, uma aspiração romântica que se coadunaria melhor

${ }^{543}$ FARIA, João Roberto. Victor Hugo e o teatro romântico no Brasil. Lettres Françaises, n. 5, 2003, p. 112. Disponível em: http://seer.fclar.unesp.br/lettres/article/view/746. Acesso em: 01 out. 2012. 
com a estrutura do drama histórico do que com o traço universalista da tragédia. Dito de outro modo, Gonçalves de Magalhães, optando pela tragédia, evita o particular e o característico que seriam mais adequados para configurar um tema supostamente nacional. "Gonçalves de Magalhães expressou, na produção dramática, o interesse por temas recorrentes da escola romântica que, a seu ver, não conflitavam com a formalização clássica." ${ }^{544}$.

O dramaturgo pensava que o teatro no Brasil deveria seguir a mesma trilha artística da Europa, produzir tragédias e, posteriormente, dramas. Para Prado, o pouco que se sabia sobre o Judeu, um comediógrafo queimado em praça pública, era o suficiente para suprir a tendência ao abstrato na obra de Magalhães. A história de Antônio José proveria um enredo condizente com a disposição do autor para defender uma causa: denunciar a Inquisição que, segundo o poeta, baseava-se em uma má interpretação do cristianismo, pois a instituição cometera injustiças e crimes; e valorizar o artista incompreendido, sacrificado pela sociedade como posteriormente o foram Tarso e Chatterton. ${ }^{545}$ Apesar disso, a estrutura em cinco atos, o número reduzido de personagens, a iminência do desenlace concentrando a ação e a linguagem clara, princípios da tragédia clássica, contribuem para que a peça mantenha a movimentação e tensão necessárias ao envolvimento do espectador. Vale lembrar que Antonio José foi encenada pela companhia teatral de João Caetano de 1838 a $1860^{546}$, o que demonstra que a peça teve fôlego, apesar de suas deficiências.

Olgiato não alcançou o mesmo sucesso, pois, ao se desvencilhar do assunto patriótico, a tragédia deslocou o centro de interesse para os seus atributos técnicos e estéticos. Nessa obra, fica mais evidente que há uma valoração das ideias em detrimento do desenvolvimento das ações e do aprofundamento das personagens. Como bem observou Lima ${ }^{547}$, a economia dos elementos de composição não suscita o aprofundamento do tema e das personagens como nas tragédias neoclássicas, mas produz cenas extensas e recorrentes, tornando a peça monótona. Dito em outras palavras, a unidade de tempo e ação bem como o número reduzido de personagens, não são suficientes para que o desenvolvimento da ação seja eficaz, pois não há conflito

544 LIMA, Mariângela Alves de. Introdução: Entre o rigor clássico e o desalinho romântico. In: MAGALHÃES, Gonçalves de. Tragédias. São Paulo: Martins Fontes, 2005, p. XXIII.

545 PRADO, Décio de Almeida. Antonio José, de Gonçalves de Magalhães. Revista USP, n. 15, 1992 , p.127.

${ }^{546}$ LIMA, Mariângela Alves de. Op. Cit., p. XXXV.

${ }^{547}$ Idem, ibidem, p. XXXVIII. 
entre os caracteres. Magalhães optou por não colocar o vilão em cena para não ofender o público e a moral, e nem acanhar o ator que interpretasse o duque:

\begin{abstract}
Si eu introduzisse Galeazzo em scena, ver-me-hia forçado, para conformarme ao gosto do tempo, a dar-lhe o seu torpe e infame caracter; o que, além de vexar o actor que o interpretasse, incomodaria os espectadores, e offenderia a moral publica; cousa de que tão pouco entre nós se cuida. Será talvez nímio escrúpulo de minha parte; mas, que jogo de scena poderia haver com um tigre que ia direito ao crime, de que alardeava? Que linguagens e acções daria eu a um tyranno, que se não fartava de devassidão, enquanto não saboreva a desesperação dos pais e dos maridos, por elle convertidos em ministros e testemunhas de sua pro pria desshonra? ${ }^{548}$
\end{abstract}

As relações entre as personagens em cena não são opositivas, o que engendra falas que repetem opiniões análogas. Os diálogos entre os jovens conspiradores e entre eles e seu mestre Montano são repetitivos, deixando de gerar suspense e interesse ao espectador que já espera pela tragédia iminente. Nesse sentido, Prado observou que os “conflitos conceituais" não são desenvolvidos porque os interlocutores rapidamente estabelecem um consenso. As discussões tornam-se variações de uma mesma ideia, justamente aquela que o autor defende.

\begin{abstract}
Os conflitos conceituais postos em cena - e para eles armou-se o enredo dissolvem-se antes de adquirir vida, porque os interlocutores, nesses debates que deveriam revelar-se decisivos, entram logo em acordo, esmeram-se em defender ideias irmãs, ou de parentesco próximo, entregando-se em opor resistência aos desígnios sempre louváveis do autor. Não se pede que este se omita, somente que não deixe entrever com tanta ingenuidade a sua presença em cena, manipulando ação e personagens. A doutrinação, em teatro, desenvolve-se dialeticamente, através de antagonismos, não de unanimidades.
\end{abstract}

Além de não apresentar um conflito externo, em anteposição direta com o antagonista, o protagonista não desenvolve nenhum dilema interno, suas ações são condizentes com sua ideologia. Ele não tem dúvidas ou arrependimentos. Assim, a ausência de pathos enfraquece a tragédia de Gonçalves de Magalhães. Os heróis de Magalhães não apresentam inquietação e morbidez romântica, mas um heroísmo estoico cuja constância e austeridade são seus melhores atributos ${ }^{549}$.

Ao renunciar a exploração de aspectos do teatro romântico, Magalhães faz com que em suas peças prevaleça a propagação de uma ideia ou causa em detrimento da

\footnotetext{
${ }^{548}$ MAGALHÃES, Gonçalves de. Prólogo a Olgiato. In: Tragédias: Antonio José, Olgiato, e Othelo. Rio de Janeiro: Livraria de B.L. Garnier, 1865, p. 133-134.

${ }^{549}$ PRADO, Décio de Almeida. Op. Cit., 1996, p. 49.
} 
construção das ações ou das personagens. No caso de Olgiato, a introdução de episódios paralelos e o desenvolvimento do entrecho amoroso poderiam contribuir para o aprofundamento da ação e a complexidade dos caracteres. A questão é que a tragédia deixa de ter "um dominante artístico, com um maior realce da série literária", comparado ao de cunho filosófico e político ${ }^{550}$.

Em contraponto, Leonor de Mendonça se vale de arcos subsidiários de ação que acrescentam suspense e aprofundam o pathos da protagonista. O entrecho amoroso é construído desde a primeira fala suscitando a relação entre a tragédia iminente e a relação amorosa, já que neste drama o trágico está associado ao envolvimento entre o jovem Alcoforado e a duquesa.

Claro está que Magalhães intentou construir uma peça político-ideológica e não se propôs a construir uma intriga amorosa aos moldes do drama romântico. Aliás, preferindo a tragédia, Magalhães privilegia a história, o universal e a moral ${ }^{551}$. Ao autor, o amor-paixão, como era apresentado nos dramas franceses, parecia-lhe imoral, devendo ser apresentado com discrição. Em sua peça, esse sentimento, tão importante para a estética romântica, torna-se acessório. O casamento entre Olgiato e Angelina é introduzido de modo repentino e não contribui para promover o sentimento de compaixão ou configurar as personagens. O mesmo esquema é vislumbrado em Antonio José, o relacionamento entre Mariana e o Judeu é abruptamente inserido na tragédia causando estranhamento. $\mathrm{O}$ amor em Magalhães parece ser apenas outro elemento de combate contra os tiranos.

\footnotetext{
O amor mal aparece em Antônio José, etiquetado, ao que parece, sob o nome de amizade. Já em Olgiato ele se manifesta, com Angelina acompanhando valentemente os seus companheiros de sedição. Mas trata-se de um sentimento especial, na linha das personagens femininas de Corneille, nascido do espírito, não do corpo, fundado sobre o respeito moral. Segundo este código, ama-se a quem se admira pelo saber e valor. Dessa forma, a mulher perde um pouco de sua especificidade, que no romantismo era dado em geral pela fraqueza, aproximando-se da forma masculina. ${ }^{552}$
}

Leonor de Mendonça, apesar de se basear em uma crônica sobre d. Jaime, não se caracteriza por representar um fato histórico, mas pela maneira de apresentá-lo. Nesse

\footnotetext{
${ }^{550}$ ABDALA JUNIOR, Benjamin. Literatura, História e Política: Literaturas de Língua Portuguesa no século XX. 2 ed., Cotia, SP: Ateliê Editorial, 2007, p. 75.

551“"Tragédia e Drama cousas são differentes; cada qual pede sua crítica especial, como a história e a chronica, o geral e o individual, a moralidade e o facto, o necessário e o contingente: não que se excluam os termos das antitheses, mas o predomínio de uma destas categorias constitue a differença das duas composições.” MAGALHÃES, Gonçalves de. Prólogo a Olgiato. In: Op. Cit., p. 137.

552 PRADO, Décio de Almeida. Op. Cit., 1996, p. 48-49.
} 
sentido, na peça são retratados sentimentos e motivações particulares das figuras históricas, o que as aproxima do público.

\begin{abstract}
Diferente do registro histórico dito científico, que costuma ostentar uma crosta de neutralidade, o drama ocupa a zona inexplorada pelo discurso referencial. Lançando mão do recheio subjetivo, o dramaturgo modela a secura dos relatos, transformando-os. (...)Por este caminho, a plateia encontra dois elementos decisivos para a sua satisfação. Observa os vultos históricos pelo ângulo inusitado das motivações particulares - então se sente muito próxima deles; e, por outro lado, seria a curiosidade por espionar-lhes a vida íntima nesse momento se sente confortavelmente superior a eles. ${ }^{53}$
\end{abstract}

No caso da peça em questão, a identificação também se dá através da complexidade das personagens, as quais não são retratadas como meros vilões e heróis de forma maniqueísta. Patkull, Leonor de Mendonça e Boabdil dirigem a atenção ao conflito sentimental, apesar de o fato histórico ser sempre evidenciado. Mas é apenas em Leonor de Mendonça que o artefato histórico torna-se secundário e, ao mesmo tempo, estruturador da peça. Dessa forma, as motivações pessoais, que são colocadas em primeiro plano, casam-se perfeitamente com os dados factuais, enleando-se e tornando a obra verossímil.

Já em Patkull, o contexto histórico (defender os direitos da Livônia contra a Suécia com a ajuda do rei da Saxônia, Augusto II) é, em grande parte, esclarecido em uma longa conversa entre Patkull e o suposto amigo do herói, Paikel (Ato I, cena V). O vilão convence Patkull a partir e deixar a noiva amada, Namry Romhor, para benefício do interesse coletivo. Paikel e Namry já haviam tido um relacionamento e se gostavam. O protagonista, a certa altura, se desespera achando que a noiva o traíra, o que, no entanto, não acontece. Nesse drama, os elementos factuais apresentam-se justapostos e não se fundem com o entrecho amoroso.

Outro recurso do teatro romântico explorado por Dias e desprezado por Magalhães é o traço local característico. O autor de Olgiato elimina o retrato dos costumes, o delineamento de quadros históricos imaginativos e de infância, bem como as reminiscências das personagens ${ }^{554}$, discordando dos preceitos hugoanos.

(...) e se M. V. Hugo pretende que o poeta deve procurar, não o belo, sim o característico, reduzindo destarte a poesia a um daguerreótipo de palavras,

\footnotetext{
${ }^{553}$ HUPPES, Ivete. Op. Cit., p. 49.

${ }^{554}$ Lima, Mariângela Alves. Op. Cit., p. XVIII e XIX.
} 
não faltará quem lhe responda, que o característico serve à poesia, mas não a constitui, e que outra é a sua missão. ${ }^{555}$

Esses artifícios, quando bem empregados, contribuem para desenvolver os caracteres, fomentar a verossimilhança referencial e a compaixão do espectador, além da atração que o peculiar pode despertar. Conforme já comentado, Dias, no caso da peça analisada, soube empregar o característico de forma integrativa, ou seja, incorporando-o à ação e às personagens. Dessa maneira, as características do espaço, as marcas temporais e os objetos cênicos adquirem sentido e função na peça e extrapolam o efeito meramente ornamental.

Gonçalves de Magalhães em Antonio José, assim como G. Dias em Leonor de Mendonça, incorpora ações cotidianas de âmbito doméstico em sua obra. Na peça do autor de Suspiros poéticos e saudades, a atriz Mariana, com a ajuda da criada, tenta curar-se de uma enxaqueca para que possa estudar o seu papel no teatro. A inserção dessa cena serve para difundir uma das ideias de cunho liberal defendidas pelo dramaturgo que é a valorização do ator. Mariana esforça-se para representar os seus papéis da melhor maneira possível, estuda suas falas até desfalecer de cansaço. Além disso, ela é apresentada como uma mulher digna e católica, enfim, um exemplo de moralidade. Nesse caso, a perspectiva histórico-social da questão do ator e do artista é atenuada devido à ênfase dada ao plano moral. A criada Lúcia tem função reflexiva, isto é, espelha a protagonista. Ela também exprime o pensamento do povo de forma pitoresca, além de contribuir para o andamento da peça como suporte da ação, levando a carta de Antonio José ao conde de Ericeira.

O mesmo recurso é utilizado por Gonçalves Dias. Paula, a camareira de Leonor, cumpre as mesmas funções que Lúcia em Antonio José. No entanto, Dias mantém a criada presente em todo o desenvolvimento do drama. Já Magalhães, que num primeiro momento coloca Lúcia em destaque, mitiga a participação da personagem após a morte súbita de Mariana. Aliás, a ama não sobrevive muito ao falecimento da patroa.

O teatro de Magalhães, como asseverou Faria, "é demasiado sério para uma época que gostava da mescla de sofrimento e riso, que apreciava o movimento, o espetáculo e histórias sentimentais." ${ }^{556} \mathrm{O}$ mesmo comentário pode ser estendido aos dramas gonçalvinos. Em Leonor, Gonçalves Dias faz concessões à comédia porque se

${ }^{555}$ MAGALHÃES, Gonçalves de. Prólogo a Olgiato. In: MAGALHÃES, Gonçalves de. Op. Cit., 2005, p. 142.

${ }_{556}^{5}$ FARIA, João Roberto (Dir.). Op. Cit., p. 81. 
propõe a fazer um drama, mas não ao riso. Somente a camareira Paula, com suas falas francas e interjeições, quebra a seriedade da peça. A cena na casa dos Alcoforado permite a elevação do que era do âmbito do gênero médio. No entanto, não contribui para a quebra da atmosfera circunspecta e sombria, pelo contrário, colabora com a lugubridade e tensão criadas.

Se o teatro de pretensões literárias e filosóficas de Gonçalves de Magalhães se afasta das propostas românticas devido às concessões ao gênero clássico, Martins Pena, embora classifique suas peças como dramas ${ }^{557}$, preferiu o melodrama, ${ }^{558}$ privilegiando o gosto do público e a efetividade dramática das peças. Os seus enredos recheados de alusões a acontecimentos da história explicam, talvez, essa classificação, mas os entrechos dinâmicos e complexos cheios de reviravoltas e mistérios não deixam dúvida de que as produções seguiam a escola de Pixerécourt. Os espaços englobam castelos, calabouços e masmorras, e o tempo, um passado distante, sobretudo de cunho medieval. Paulo Ronái chama atenção para a falta de qualidade dos dramas de Martins Pena em comparação às comédias ${ }^{559}$. Observe-se que a maneira como o estudioso descreve as peças sérias de Pena remete às características do melodrama:

\begin{abstract}
As personagens lançam-se aos monólogos enormes ou contam às outras sucessos que deveriam estar cansadas de saber para nos dar lições de história espanhola ou portuguesa. Abundam as coincidências, dei ex machina [sic], reconhecimentos, ressurreições alternando com os requisitos mais lúgubres do melodrama, cuja ingenuidade ainda mais avulta pelo estilo grandiloquente e vazio. Em suma, os dramas em nada contribuem para a glória do escritor Martins Pena, mas também não diminuem a grandeza do comediógrafo. ${ }^{560}$
\end{abstract}

${ }^{557}$ Martins Pena escreveu cinco [melo]dramas: Fernando ou O cinto acusador (1837), D. João de Lira ou $O$ Repto (1838), Itaminda ou o Guerreiro de Tupã, segundo Faria a peça foi desenvolvida provavelmente antes de 1839, D. Leonor Teles (1839) e Vitiza ou O Nero de Espanha (1839-1840). FARIA, João Roberto (Dir.). Op. Cit., p. 86.

558 "O universo dramatúrgico no qual estavam mergulhados - uma mistura de melodrama e drama histórico romântico, indivisível a não ser pela análise - opunha-se radicalmente a tragédias como Antônio José e Olgiato. A ação, uma só no classicismo, estilhaçara-se, dando origem a um enredo cheio de voltas e reviravoltas, de protagonistas e antagonistas que se batem em vários confrontos menores até atingir o ponto de saturação no grande e decisivo confronto final." PRADO, Décio de Almeida. Op. Cit., 1996, p. 54.

${ }^{559} \mathrm{O}$ julgamento de valor feito por Ronái é pertinente se atentarmos para a grande quantidade de clichês, personagens planas e situações sem significado profundo dos dramas do grande comediógrafo, além do uso de uma linguagem copiosa e afetada que não se coaduna com a do enredo. Nessa direção, vale a pena citar Rosenfeld: "Sem dúvida, há ficção de baixo nível estético, de grande pobreza imaginativa (clichês), com personagens sem vida e situações sem significado profundo, tudo isso relacionado com a inexpressividade completa dos contextos verbais (que por vezes, contudo, são afetados e pretensiosos, sem economia e sem função no todo, sem que à sua exagerada riqueza corresponda qualquer coisa na camada imaginária e nos planos profundos)." ROSENFELD, Anatol. Op. Cit., 2009, p. 37.

${ }^{560}$ RONÁI, Paulo. Martins Pena redivivo. Diário de Notícias. 19 de maio de 1957 apud ALMEIDA, Rafael Loureiro de. Op. Cit., p. 12. 
Segundo Almeida ${ }^{561}$, não há excesso de alusões históricas em todos os dramas de Martins Pena. Para ele, exigir dos dramas românticos a concisão característica do drama moderno (e também da tragédia clássica) seria anacronismo. Aliás, é comum o uso dos diálogos narrativos por meio das conversações entre personagens ou entre personagem e público nos dramas e melodramas românticos. No entanto, o excesso de narratividade compromete a ação e o efeito dramático das peças. Além disso, ao narrar a ação e pensamentos deixando tudo explícito para o espectador/leitor, os caracteres e a obra perdem complexidade, pois não se deixa espaço para suposições ou alternativas de interpretação.

\begin{abstract}
A obviedade, a ausência de ambiguidade na comunicação com o público, são básicas no melodrama. [...] Nas peças de Martins Pena e Burgain, esse papel de esclarecimento junto ao público é entregue em boa parte aos frequentes monólogos. A função deles [...] é somente dramática, não a de aprofundar conflitos interiores, como em Racine ou Corneille. Na economia interna das peças brasileiras, cabia ao solilóquio ligar uma cena coletiva a outra ou rememorar o que acabara de suceder, projetando as possibilidades imediatas. ${ }^{562}$
\end{abstract}

Fernando, o vilão de $O$ cinto acusador ${ }^{563}$, é um exemplo do excesso de narratividade expresso por Ronái, já que os solilóquios e apartes dessa personagem esclarecem todas as ações, intenções e pensamentos. O exagero do uso de tais recursos torna as falas redundantes, e as personagens evidentes demais. No excerto a seguir, Fernando narra ações que o espectador/leitor acabou de assistir/ler. Não é necessário fazer um resumo dos acontecimentos que são evidentes. No entanto, esse era um recurso essencial ao melodrama:

FERNANDO, só - Que série de acontecimentos em tão pouco tempo! Sofia prestes a ser minha, mais cinco minutos e eu era senhor de Sofia e de suas riquezas, porém D'Harville chega e tudo se transtorna. Julgamos Sofia morta

\footnotetext{
${ }^{561}$ ALMEIDA, Rafael Loureiro de. Op. Cit., p. 65.

${ }^{562}$ PRADO, Décio de Almeida. Op. Cit., 1996, p. 57.

${ }^{563}$ A comparação entre Fernando e Leonor de Mendonça pode parecer incongruente no sentido de que a peça de M. Pena, segundo Darcy Damasceno, além de ser considerada temporalmente a primeira composição, é reputada como o mais fraco dos dramas de Pena, enquanto a peça gonçalvina estudada é julgada a obra prima do autor. No entanto, a principal intenção aqui não é fazer juízo de valor, mas confirmar a primazia de Gonçalves Dias na concepção de dramas românticos em um contexto em que prevalecia o melodrama e ainda persistia a tragédia neoclássica. De qualquer forma, Arêas opina ser difícil escolher qual o pior drama de Martins Pena, já que todos "se assemelham em incompetência de execução, estilo enfático e palavroso e inconsciência dos recursos do palco [...]”. ARÊAS, Vilma Sant'Anna. Op. Cit., 1987, p. 100.
} 
e o Marquês dá-me a entender que seria seu herdeiro; ainda bem não me tinha possuído desta ideia, que Sofia retorna a reviver. ${ }^{564}$

Em Leonor de Mendonça, o autor também faz o uso da narração para expor acontecimentos ou os pensamentos e sentimentos das personagens. No entanto, ele o faz de forma mais consciente porque evita as obviedades e o desequilíbrio na extensão das falas. Gonçalves Dias insere as falas narrativas quando há dificuldade de incluir o acontecimento como ação, como no caso do ataque do javali, relatado por Leonor posteriormente a sua camareira. Ora, nada mais natural que a dama conte a sua camareira mais íntima como tudo tinha acontecido. Além disso, como discutido em capítulo anterior, a narração da caçada têm um sentido metafórico e simbólico que colabora para a densidade da obra. O duque, por sua vez, narra os infortúnios por que passou, e esses fatos são imprescindíveis à construção da personagem, pois seus sentimentos são contrabalanceados por seus atos, isto é, suas atitudes são psicologicamente justificadas. Já Fernando, por meio de solilóquios e apartes, narra seus planos e sentimentos apenas para mostrar a extensão de sua maldade, o que colabora para que o seu perfil seja plano ${ }^{565}$.

A propósito, o fato de Fernando ser guiado por uma cobiça desmedida e aludir ao inferno em algumas de suas falas aproxima-o ainda mais dos caracteres melodramáticos e de uma visão maniqueísta. Dentre os vilões gonçalvinos Francisco Cenci é o que mais se apropria das características do antagonista padrão dos melodramas e dos romances góticos. Paikel, D. Jaime e Boabdil já apresentam a ambiguidade e a relativização psicológica típica das personagens românticas. No entanto, para falar com Prado, as ações cruéis de Francisco, diferentemente das dos vilões de Pena, não são infundidas por um interesse banal em proveito próprio, mas "como um entretenimento da inteligência" e "um escárnio moral para os outros". Os exercícios de maldade servem-lhe para ocupar o vazio existencial e a ausência de amor. Mesmo quando pensa amar Beatriz, nela só consegue ver a si mesmo566: "Quero

${ }^{564}$ PENA, Martins. Fernando ou O cinto acusador. In: Teatro de Martins Pena: dramas. Vol. II. Edição crítica Darcy Damasceno. Rio de Janeiro: Rio de Janeiro, MEC, INL, 1956, p. 33.

565 Prado adverte que o confidente, o solilóquio e o aparte, embora sejam formas utilizadas com certa frequência para expressar as revelações interiores das personagens teatrais, são recursos um pouco artificiais; o aparte, por exemplo, "jamais exerceu funções de grande transcendência: recurso favorito da farsa e do melodrama, o seu fim, via de regra, era menos analisar as personagens do que prevenir o público quanto ao andamento presente ou futuro da ação, não o deixando equivocar-se com referência ao sentido real da cena." PRADO, Décio de Almeida. Op. Cit., 2009, p. 89.

${ }^{566}$ PRADO, Décio de Almeida. Op. Cit., 1996, p. 96-97. 
extasiar-me de te ver, quero-me rever na tua beleza (...)"567. O prazer de Francisco Cenci advém do sofrimento alheio, pois ele se fascina presenciando a extensão de seu poder e força sobre a fraqueza das outras personagens.

A propósito, Beatriz Cenci ${ }^{568}$ - cujo enredo Swigger resumiu como um drama em que "two women seek revenge upon a man whom they ought to love as husband and father" ${ }^{\prime 59}$-, em muitos aspectos antecipa Leonor de Mendonça. A questão mais saliente é a baldada luta dos fracos contra os fortes, mais particularmente, das mulheres contra o poderio do homem como senhor, da esposa contra o marido ${ }^{570}$, da filha contra o pai. Lucrécia e Beatriz, num primeiro momento, mostram-se subservientes, mas, quando advém o desespero e o ódio, elas se mostram determinadas e tentam se vingar. Nesse sentido, geralmente o ato de vingança é atribuído às personagens masculinas, mas, aqui, duas mulheres são responsáveis por arquitetar a morte de D. Francisco.

Na peça da duquesa de Bragança, Leonor também muda sua atitude para lutar pela vida e tenta desafiar o poder do marido. A diferença no sentido de efetividade dramática estaria, por exemplo, na brusca mudança de temperamento da personagem Beatriz. Talvez isso se dê devido ao corte que o autor é obrigado a fazer por conta do decoro neoclássico. O leitor/espectador não presencia o aviltamento sofrido pela personagem, mas poderia haver uma cena ou um ato de transição em que a personagem demonstrasse o processo de mudança advindo do choque que sofrera. Gonçalves Dias parece ter aprendido com a experiência da "excomunhão de sua Beatriz". Em Leonor de Mendonça ele manteve ainda mais o decoro, evitando colocar mortes em cena. $\mathrm{Na}$ verdade, há a tentativa de traçar um perfil psicológico das personagens de Beatriz Cenci, bem concebido, principalmente, em Lucrécia. Contudo, como pontuou Prado, “tudo passa depressa demais" para que os contornos não incorram em meros esboços.

\footnotetext{
${ }^{567}$ DIAS, Gonçalves. Beatriz Cenci. In: Op. Cit., p. 851.

${ }^{568}$ Leia-se a versão proposta por Gonçalves Dias para a tragédia ocorrida em Nápoles no final do século XVI: Beatriz Cenci é mantida em cativeiro por seu pai, d. Francisco, até a adolescência, quando ele então decide seduzi-la. A sua esposa, d. Lucrécia, madrasta de Beatriz, prevê os planos do marido e tenta evitar o pior apoiando o namoro da menina com Márcio, jovem nobre que também se apaixonara pela garota. Entretanto, durante um baile de máscaras, promovido para alcançar os seus desígnios, d. Francisco desonra a filha. Humilhadas, Beatriz e Lucrécia armam um plano para vingarem-se do vilão com o auxílio de Márcio. O mancebo morre na tentativa de ajudar a amada e d. Lucrécia, apesar de conseguir matar o marido, perece em suas mãos.

569 SWIGGER, Nancy Louise Duncan. Gonçalves Dias' Dramas. Ph. D. (Language and Literature), Indiana University, 1969, p.73.

570 "D. FRANCISCO - Estais hoje insuportável de embotado que tendes o vosso espírito. Não compreendeis que depois do marido vem o senhor, e que depois do rogo vem a ordem?" e "D. LUCRÉCIA: [...] - A escrava vinga-se do Senhor que era um infame, - e a mulher vinga-se do marido que era grosseiro e cobarde. Estás envenenado!” DIAS, Gonçalves. Beatriz Cenci, In: Op. Cit., p. 853 897.
} 
Também é bastante característico nas duas obras o código da nobreza em que a honra prevalece como valor: Francisco desdenha a pobreza em que vivia Lucrécia antes de se casar com ele. Como resposta ela relembra ao marido a sua rica ascendência, enfatizando a antiguidade de sua casa em relação à dele ${ }^{571}$. O duque de Bragança também humilha a esposa que não aceita tais injúrias, consciente de sua posição hierárquica. Beatriz vinga-se da humilhação que sofre diante de Márcio e não do aviltamento sofrido, demonstrando valorizar sobretudo a sua imagem social. Em Leonor, a duquesa também se preocupa com a deterioração de sua reputação: “A DUQUESA: - Senhor, é de joelhos que eu vo-lo peço; não me obrigueis a corar morrendo, nem a suportar a piedade hipócrita dos meus inferiores, que em torno de mim se estarão rindo interiormente com o meu suplício e com a minha desdita!"572

Voltando à comparação com Fernando ou $O$ cinto acusador ${ }^{573}$, o objetivo da peça, de acordo com Almeida ${ }^{574}$, é tão somente emocionar e entreter o público, não revelando lição moral alguma. As situações dramáticas teriam um fim em si mesmas e não impulsionariam nenhuma reflexão, o que as aproximaria dos princípios do melodrama. $\mathrm{O}$ estudioso parece se esquecer, nesse comentário, do fim moralizante das peças melodramáticas. Aliás, a morte dos protagonistas nessa peça não implica a falta de uma lição moral. O vilão morre pagando pelas perfídias, assassinatos e ganância desmedida. O equilíbrio e a ordem anterior são, de alguma forma, restabelecidos.

O interessante em Fernando é que, além da figura do vilão sobrepujar a do herói D’Harville, como nos romances góticos (até mesmo na escolha de um dos títulos da obra, Fernando), Valentim, o coadjuvante, mostra-se mais sábio e moderado que seu

\footnotetext{
571 "D. LUCRÉCIA - Felizmente, senhor, eu nunca me assentei nas escadarias do vosso palácio, e não mendiguei o título de vossa esposa; - muito antes que o vosso nome fosse conhecido, mesmo pelos barqueiros do Tibre, o meu nome de família — o apelido — dos "Petroni" figurava dignamente entre os mais ilustres do seu tempo." Idem, ibidem, p. 853.

572 Idem, Op. Cit., p. 954.

${ }^{573} \mathrm{O}$ enredo baseia-se nas perfídias cometidas pelo vilão Fernando. A intenção inicial do antagonista é herdar a fortuna do Marquês de Salvati casando-se com sua filha, Sofia. No entanto, o Marquês já prometera a mão de Sofia ao capitão D'Harville. Fernando arma um plano para desonrar o Capitão que é expulso por Salvati e agrega-se ao exército em busca da morte após perder a amada. O vilão consegue a promessa de casamento, mas D'Harville volta para atrapalhar seus planos e descobre que Fernando também fora responsável pela morte de seu pai. Ao final, os inimigos se enfrentam, mas Fernando consegue matar Sofia e o Capitão antes de ser rendido pelo braço direito de D'Harville, Valentim.

574 "A história de Fernando ou O cinto acusador se resolve desse modo, numa convergência de linhas arquetipicamente trágicas. Isso não significa dizer que a história seja uma autêntica tragédia, pois não propõe grandes mensagens moralizantes ou reflexões profundas aos espectadores. A intenção é tão somente emocioná-los e entretê-los por algum tempo. Desse modo, o esforço autoral se concentra em produzir situações dramáticas como um fim em si mesmo, e é por isso que os dramaturgos românticos o chamavam drama, assim como será o motivo de alguns teóricos modernos preferirem chamar de melodrama." ALMEIDA, Rafael Loureiro de. Op. Cit., p. 117-118.
} 
Capitão. É ele quem mata o vilão. Essa questão parece enfraquecer ainda mais a figura de D’Harville e a eficácia do melodrama.

Raimundo Magalhães nota em Fernando uma pretensão à tragédia, baseando-se no desfecho trágico da peça em que o casal de protagonistas é assassinado pelo vilão e no prenome do herói, Aquiles ${ }^{575}$. É importante lembrar que nos dramas românticos e melodramas resquícios da tragédia neoclássica são ordinários, principalmente no contexto de produção de Martins Pena. Basta lembrar que essas produções ainda eram correntes no repertório nacional. Ademais, como já foi comentado anteriormente, Leonor de Mendonça também apresenta características da tragédia clássica francesa, como observou Prado.

Voltando à questão da moralidade, pode-se comparar a postura dos dois autores em suas respectivas obras Leonor de Mendonça e D. Leonor Teles. Gonçalves Dias optou por não apresentar Leonor como uma personagem que paga por uma falta cometida, enquanto a Leonor de Martins Pena, bem como D. Fernando e Andeiro, é castigada em justa medida em relação a seus crimes, como esclarece o dramaturgo no prefácio da obra.

\footnotetext{
Apresento neste drama as seguintes lições morais: D. Leonor esquece-se do juramento dado perante Deus a seu esposo, manda assassinar sua irmã e é castigada pela mesma ambição motora de seus crimes; D. Fernando paga com amargurados dias que passou, e com a morte, a sua fraqueza e inconstância; e Andeiro acaba violentamente por ousar lançar cubiçosos olhos sobre o Trono. 576
}

No entanto, ao criticar as obras de cunho melodramático deve-se ter em conta que a antipatia em relação a esse gênero e ao drama romântico, que perdura até hoje, também se deve ao contexto político brasileiro coetâneo da produção dessas obras. $\mathrm{O}$ romantismo abordou o ideário iluminista de liberdade por meio da crítica às instituições, apresentando em seus enredos reis, rainhas e nobres devassos, heróis rebeldes, situações “imorais" e degradantes. Essa perspectiva herdada da Revolução Francesa não se coadunava com a situação de instabilidade da Regência, nem com o período de solidificação do reinado de d. Pedro II, cuja imagem estava sendo positivamente construída. Por esse motivo e pela questão moral, a intelectualidade brasileira

\footnotetext{
${ }^{575}$ ARÊAS, Vilma Sant'Anna. Op. Cit., 1987, p. 101.

576 PENA, Martins. Prefácio de D. Leonor Teles. In: Teatro de Martins Pena: dramas. Vol. II. Edição crítica Darcy Damasceno. Rio de Janeiro: Rio de Janeiro, MEC, INL, 1956, p. 116.
} 
interpretou os dramas de Alexandre Dumas e Victor Hugo "como algo que se aproximava de uma escola de corrupção." 577

A imprecisa definição dos gêneros drama histórico e melodrama pode ser mais bem entendida se se levar em conta a interação entre Brasil e Portugal no que concerne às produções dramáticas. Aliás, segundo $\operatorname{Prado}^{578}$, o teatro brasileiro durante o século XIX e início do século XX continuou arraigado à dramaturgia portuguesa ${ }^{579}$, embora já no decurso do romantismo, o teatro francês, sobretudo melodramas, tenha sido traduzido diretamente do original. A proeminência das peças melodramáticas deve-se também ao fato de que essas produções eram muito mais rentáveis do que as peças mais literárias, pois embora fossem mais comerciais eram cenicamente efetivas. Para João Caetano, por exemplo, os melodramas, especialmente os franceses, além de proporcionarem mais lucro, ofereciam-lhe a chance de se avultar como artista. "Se ele fosse auxiliar os autores estreantes, não teria quem o auxiliasse. Só se lhe apresentavam duas soluções: ou sacrificar-se como ator ou sacrificar a incipiente dramaturgia nacional. ${ }^{5} 50$

Em Portugal, Almeida Garrett tinha um projeto que visava desenvolver o teatro português, privilegiando temas e autores nacionais. Além disso, para ele, o drama romântico seria uma forma de conhecer o passado para compreender o presente evitando, assim, os erros cometidos anteriormente. Nesse sentido, a fim de impulsionar o teatro nacional e diminuir a influência do teatro estrangeiro, ele sugeriu que se buscasse nas histórias dos reis portugueses antigos, as quais possuíam grande potencial dramático, matéria para a produção de tragédias e comédias.

Essa sugestão estimulou uma grande produção de peças baseadas em fatos históricos. No primeiro concurso promovido pelo Conservatório de Arte Dramática em 1836, também por sugestão de Garrett, nas mais de 20 peças apresentadas a temática histórica prevaleceu, mas estruturalmente elas eram predominantemente melodramáticas. Durante todo o século XIX, o melodrama histórico prevalecerá em Portugal com todas as convenções do gênero. Em espaços fechados e sombrios aconteciam crimes horríveis, que eram castigados após os protagonistas vivenciarem

\footnotetext{
577 SILVA, Raquel Barroso. Teatro nacional: a construção de uma ideia no século XIX. Antíteses, v. 6, n. 12, p. 436-455, jul./dez. 2013.

578 PRADO, Décio de Almeida. Op. Cit., 1972, p. 137.

${ }^{579}$ Idem, ibidem, p. 140.

${ }^{580}$ Idem, ibidem, p. 137-138.
} 
inúmeras peripécias e coincidências mirabolantes. O castigo do vilão reafirmava uma visão maniqueísta do mundo.

Os ganhadores do concurso (Mendes Leal, Silva Abranches, Inácio Maria Feijó e Pedro Sousa de Macedo) não compreenderam a proposta de Garrett. Assim, eles disseminaram a produção de peças em que a cor local se restringiu ao pitoresco, não conseguindo expressar a essência do passado, nem reflexão alguma sobre o presente ou futuro. Essa tendência foi tão significativa que alguns críticos questionam se de fato houve, em Portugal, uma verdadeira dramaturgia romântica. Duarte Ivo Cruz acredita que o único dramaturgo romântico da literatura portuguesa foi Almeida Garrett, cujas obras Um Auto de Gil Vicente (1838) e Frei Luís de Sousa (1843) atestam sua primazia $^{581}$.

\begin{abstract}
Em Portugal, nas mãos de Garrett, o romantismo perde a virulência, suavizase, sentimentaliza-se, revela a sua face angélica, frequente na poesia lírica mas raríssima no palco. João Caetano encena duas de suas peças, as mais conhecidas e de maior expressão: Um Auto de Gil Vicente, com que se inicia em 1838 o teatro românico em Lisboa, e Frei Luís de Sousa, considerado a obra-prima do repertório português do século XIX. Ambas são literárias, por tratarem da vida de escritores célebres, por estarem recheadas de alusões a livros e poesias, por suporem, no público, uma receptividade e uma sensibilidade especiais. Nada de traições, perseguições, represálias sanguinolentas: somente desencontros, melancólicos ou trágicos, de corações ou de destinos. Ambas voltam-se saudosamente para um passado de grandeza nacional mas não são rigorosamente históricas: preferem aquela franja entre a poesia e a história, entre a verdade e a legenda, entre o que foi e o que poderia ou deveria ter sido. Não o real mas o poético. ${ }^{582}$
\end{abstract}

Parece oportuno compararmos a tentativa de Garrett com a de Gonçalves Dias no que respeita à introdução do drama romântico e à renovação do teatro em seus respectivos países ${ }^{583}$. Aliás, as duas peças consideradas as obras primas desses autores, Frei Luís de Souza ${ }^{584}$ e Leonor de Mendonça, têm características afins. Um dos aspectos

${ }^{581}$ SILVA, Edson Santos. Estéticas teatrais portuguesas na época da Garrett. Todas as Musas, Ano 3, n. 1, jul./dez. 2011, p.187.

582 PRADO, Décio de Almeida. Op. Cit., 1972, p. 45.

583 "Um Auto de Gil Vicente, composto por Garrett em 1838, coincidindo com a chegada de Gonçalves Dias a Portugal, apresentou-se com ares de manifesto. Em seu prefácio o autor examinou à sombra de Gil Vicente (cujas Obras Completas eram publicadas nesse mesmo ano em Hamburgo por J.V. Barreto Feio e J. Monteiro) as causas da decadência do teatro nacional e propôs medidas capazes de reerguê-lo. Procurou aclimatar em Portugal as ideias que trouxera de seus estágios no exterior, principalmente da França, como, por exemplo, a de empregar a cor local às peças, sobretudo nas de assunto lusitano. Para o jovem poeta maranhense, não era essa postura garrettiana um excelente assunto para meditar e, quem sabe, um dia imitar?" HESSEL, Lothar; RAEDERS, Georges. Op. Cit., p. 93.

${ }^{584} \mathrm{O}$ contexto histórico do enredo de Frei Luís de Sousa aborda a resistência à dominação filipina após o desaparecimento do rei d. Sebastião na Batalha de Alcácer-Quibir em 1578 e o mito sebastianista disseminado durante o período. A peça é baseada na vida de Frei Luís de Sousa, d. Manuel de Sousa Coutinho, que se casa com d. Madalena de Vilhena, cujo primeiro marido, d. João de Portugal, assim 
que as aproxima é a manutenção de elementos clássicos, como a unidade de ação, o número reduzido de personagens, a ênfase nos presságios e na fatalidade, a concentração dramática e o adensamento do pathos no decorrer da ação. Também a sobriedade da linguagem é partilhada por ambos, embora ao mesmo tempo apreendam a expressividade de cunho romântico, por exemplo, na inclusão (não demasiada) de falas extensas de cariz declamatório e a exploração de recursos como o uso da exclamação, das reticências e da interrogação para revelar o estado emocional das personagens.

Como no drama de índole trágica garrettiano, em Leonor de Mendonça não é apenas o conflito que importa, mas a criação de uma atmosfera tensa e opressiva por meio das premonições e pressentimentos que valorizam as cenas anteriores ao conflito central, bem como o delineamento psicológico dos caracteres. Objetos e acontecimentos corroboram para adensar essa atmosfera, como no caso dos retratos em Garrett ${ }^{585}$ e do episódio da caçada em Dias.

\begin{abstract}
O mundo exterior contemplado no Frei Luís de Sousa (paisagens, quadros, retratos) não tem em si uma existência independente de quem o assinala: as coisas e objectos observados sofrem, em determinado momento da contemplação, uma <interpretação> que simultaneamente os carrega de força trágica e os insere no drama. Essa interpretação só é possível através da intuição permanente de uma fatalidade desastrosa a cair sobre Madalena e sua família. É essa intuição que relaciona o objeto observado com a situação psicológica do observador tornando-o vivo e actuante como se de uma personagem se tratasse. ${ }^{586}$
\end{abstract}

Os dois autores souberam escolher enredos de exemplar tragicidade e adequados à concepção de drama romântico ${ }^{587}$. Em Frei Luís de Sousa (e também em Leonor de Mendonça) a severidade da tragédia antiga se entrelaça com uma dialética dos

como o monarca também desaparecera após a funesta batalha. A união entre Manuel e Madalena acontece após sete anos de ausência de d. João, e o casal tem uma filha, Maria. No entanto, Madalena vive com medo de que o primeiro marido regresse, e esse temor é alimentado pelos presságios da filha Maria e de seu criado, Telmo. Vinte anos depois, D. João regressa e desestabiliza a nova família de esposa. Sentido-se culpados pelo adultério, Manuel e Madalena tomam o hábito religioso e a filha, sendo fruto de uma união indigna, tragicamente morre durante a cerimônia de ordenação dos pais.

${ }^{585}$ D. Madalena tenta salvar o retrato do atual marido das chamas quando a família deixa a casa de $\mathrm{d}$. Manuel para ir à antiga casa onde ela vivera com d. João. Nesse palácio, o retrato do antigo cônjuge a atormenta como um prognóstico de seu retorno e do fim de seu relacionamento com d. Manuel.

586 OLIVEIRA, Luís Amaro. Quando as coisas e objectos actuam como personagens. In: GARRETT, Almeida. Frei Luís de Sousa. Realização didática Luís Amaro de Oliveira. Porto: Porto Editora, 1987, p. 67.

${ }^{587}$ MARTINS, José Cândido de Oliveira. Para uma sistematização didáctica das leituras interpretativas do Frei Luís de Sousa de Almeida Garrett. In: MONTEIRO, Ofélia Paiva; SANTANA, Maria Helena Santana (Org.). Almeida Garrett, Um Romântico, Um Moderno, vol. II, Lisboa: IN-CM, p. 9. 
sentimentos que lhe confere um cunho inconfundivelmente romântico ${ }^{588}$. Ciente de que sua obra divergia formalmente da tragédia grega, Garrett preferiu denominá-la drama, apesar do traço trágico que a trespassa. Para ele:

\begin{abstract}
É singular condição dos mais belos factos e dos mais belos caracteres que ornam os fatos portugueses, serem tantos deles, quase todos eles de uma extrema e estreme simplicidade. As figuras, os grupos, as situações da nossa história - ou da nossa tradição - que para aqui tanto vale - parecem mais talhados para se moldarem e vazarem na solenidade severa e quase estatuária da tragédia antiga, do que para se pintarem nos quadros, mais animados talvez, porém menos profundamente impressivos, do drama novo - ou para se entrelaçarem nos arabescos do moderno romance. ${ }^{589}$
\end{abstract}

Saraiva assevera que, embora a obra garrettiana mantenha as formas do teatro antigo, apresenta um conteúdo muito diferente. A fim de delinear as características do drama de Garrett, ele explica que o teatro grego baseia-se na luta do homem contra a fatalidade; o teatro clássico, raciniano, apresenta um enredo baseado nas paixões humanas que se evidenciam nas ações e reações decorrentes de suas interrrelações. Já o drama representa a autorrevelação do homem que é provocada por um acontecimento externo que o destino lhe impõe. A intriga, a ação e o choque entre as personagens, na opinião do crítico, perdem sua importância, pois a crise da personagem encontra-se latente, e o acontecimento exterior serve apenas para desencadeá-la.

O protagonista, na interpretação de Saraiva, Telmo Pais, se vê num dilema, ajudar seu velho amo d. João a restaurar sua vida ou não deixar Maria, a filha ilegítima de d. Manuel e Madalena, cair em desgraça pública. Telmo descobre que, na realidade, prefereria que d. João tivesse morrido na batalha de Alcácer-Quibir, desvelando a si mesmo uma personalidade diferente da que pensava ter ${ }^{590}$. Essa descoberta de cunho tão subjetivo, no entanto, não interfere no destino dos protagonistas.

Nesse sentido, a obra do autor português se aproxima mais da tragédia grega do que Leonor de Mendonça, pois, como Gonçalves Dias esclarece no Prólogo, seu drama se baseia no choque entre as personagens, as quais agem pautadas nos hábitos de civilização. O crime de d. Jaime se apoia nas prerrogativas de sua posição social, e Leonor e Alcoforado, socialmente desprivilegiados, sofrem as consequências. Contudo,

${ }^{588}$ REBELLO, Luiz Francisco. O Teatro Romântico (1838-1869). Lisboa: Instituto de Cultura e Língua Portuguesa, 1980, p. 47.

${ }^{589}$ GARRETT, Almeida. Memória ao Conservatório Real. In: GARRETT, Almeida. Op. Cit., 1987, p. 216.

${ }^{590}$ SARAIVA, António José. Telmo Pais - A Personagem Central de Frei Luís de Sousa. In: GARRETT, Almeida. Op. Cit., p. 20-21. 
a duquesa não deixa de apresentar um dilema interior, mas não foi esse o prisma que Gonçalves Dias intentou valorizar. Vale salientar que a análise de Saraiva deve-se à ênfase dada à personagem do velho escudeiro, pois, se fosse concedida à d. Madalena, seria mais fácil visualizar aspectos do drama romântico na peça.

Entre as duas obras até mesmo algumas questões temáticas podem ser comparadas, como a divergência entre os imperativos sociais em relação ao casamento e o desejo feminino. Em Dias o adultério não se realiza porque Leonor retrai os seus sentimentos, em Garrett, inicialmente Manuel de Sousa e dona Madalena, ao equivocarem-se com a possibilidade de que que d. João tivesse morrido na batalha de Alcácer-Quibir, pensaram que poderiam se casar. Assim, o adultério nas duas peças é trabalhado de uma maneira bastante sutil, já que em nenhum dos casos os amantes podem ser, de fato, considerados culpados. Além disso, ao retratarem uma sociedade cujo apelo religioso é bastante incisivo em se tratando de um país católico, Portugal do século XVI, os autores apresentam o tema da infidelidade sob o ponto de vista da lei dos homens e de Deus. Leonor e Madalena sabem que foram as circunstâncias que as fizeram parecer adúlteras (no caso de Madalena, efetivamente, embora não pudesse ser totalmente condenada, já que o marido desaparecera na batalha de 1578) e que poderiam, nesse sentido, ser perdoadas. Mas, em pensamento, pela perspectiva cristã, foram traidoras.

A DUQUESA - Ah! Sim, meu padre, a ação pertence à criatura, mas as circunstâncias vêm... talvez do céu. Serei criminosa para Deus, porém, sou inocente para os homens. Ouvi. Na minha soledade houve um mancebo que se compadeceu de mim, talvez porque adivinhou os sofrimentos que eu curtia silenciosa; desvelou-se no meu serviço; cercou-me de solicitudes, velava incessantemente sobre mim. E eu conheci que ele era respeitoso e cheio de extremos, e que o seu amor era nobre, inocente e puro, como sua alma! Dizei-me, fiz mal em o não expulsar da minha presença? ${ }^{591}$

MADALENA - [...]. Este amor, que hoje está santificado e bendito no Céu, porque Manuel de Sousa é meu marido, começou com um crime, porque eu amei-o assim que o vi... e quando o vi, hoje, hoje... foi em tal dia como hoje! - D. João de Portugal ainda era vivo. O pecado estava-me no coração: a boca não o disse... os olhos não sei o que fizeram, mas dentro da alma eu já não tinha outra imagem senão a do amante... já não guardava a meu marido, a meu bom... a meu generoso marido... senão a grosseira fidelidade que uma mulher bem nascida quase que mais deve a si do que ao esposo. Permitiu Deus... quem sabe se para me tentar?... que naquela funesta batalha de Alcácer, entre tantos, ficasse também D. João. ${ }^{592}$

${ }^{591}$ DIAS, Gonçalves. Op. Cit., p. 961.

592 GARRETT, Almeida. Frei Luís de Sousa. In: Teatro de Almeida Garrett, vol. III, Lisboa, 1844, p. 108. 
É notória também a projeção do modelo romântico sobre o tempo histórico dos dramas, sobretudo na caracterização das personagens femininas e das relações que elas estabelecem com os caracteres masculinos ${ }^{593}$. Leonor e Madalena não têm autonomia e, por isso, aceitam morar em espaços que lhes trazem infortúnios. D. Madalena, a princípio, recusa-se a morar em sua antiga casa, na qual vivera com d. João, mas acaba cedendo ${ }^{594}$. A duquesa gonçalvina prefere viver na corte, mas acompanha o marido que deseja ficar em Vila Viçosa ${ }^{595}$. Também é possível inferir nas duas obras o tema do constrangimento da mulher ao casamento ceifando-lhe a infância e a adolescência. Sujeitas às convenções sociais e a acordos matrimoniais, as personagens são confinadas ao lar e aos papéis de esposa e mãe. No entanto, Garrett e Gonçalves Dias acrescentam às personagens o dilaceramento da paixão, colocando-as entre a vontade de vivenciar seus desejos e as exigências sociais de fidelidade conjugal. Dessa forma, há, no romantismo, uma tendência para reafirmar o perfil impotente e vulnerável da mulher, construindo-a como um ser naturamente frágil, propenso à lubricidade e à luxúria, inclinação que deveria ser censurada e castigada. No entanto, essa literatura discretamente começa a disseminar e a valorizar a sexualidade feminina, talvez porque aos românticos era cara a associação do feminino com as ideias de contradição, principalmente no que concerne à oposição entre espírito e corpo ${ }^{596}$.

Contraditoriamente, a força dessas duas personagens, Leonor e Madalena, reside na fragilidade. Mesmo sendo subjugadas e temerosas, ambas lutam pelo direito de amar e pela vida com um entusiasmo que destoa do caráter submisso apresentado. Esse arrebatamento é fortemente marcado em falas de grande força lírica. No entanto, as personagens não logram êxito, Leonor é assassinada, e Madalena toma o hábito religioso. Esse comportamento das protagonistas, em contraste com a condição social que lhes imputa uma conduta dócil e subserviente, contribui para a constituição e enredamento das personagens. Note-se que, mesmo nessas falas, que se assemelham

593 BRILHANTE, Maria João. Figurações do Feminino em Frei Luís de Sousa de Almeida Garrett. Universidade Aberta, 2006, p. $38 . \quad$ Disponível https://repositorioaberto.uab.pt/bitstream/10400.2/405/1/discursosAlmeidaGarrett31-51.pdf.pdf. Acesso em: 20 jan. 2014.

594 "MADALENA - Pois sairemos, sim; eu nunca me opus ao teu querer, nunca soube o que era ter outra vontade diferente da tua; estou pronta a obedecer-te sempre, cegamente, em tudo. Mas oh! Esposo da minha alma... para aquela casa não, não me leves para aquela casa!" GARRETT, Almeida. Frei Luís de Sousa. Realização didática Luís Amaro de Oliveira. Porto: Porto Editora, 1987, p. 78.

595 “A DUQUESA - Não é do meu dever seguir-vos para onde vos aprouver levar-me?" DIAS, Gonçalves. Op. Cit., p. 931.

${ }^{596}$ BRILHANTE, Maria João. Op. Cit., 2006, p. 35-41. 
pelo teor dramático que o desespero advindo da diminuição do tempo de vida incute nas personagens, a duquesa confronta-se com d. Jaime adensando a ideia do choque entre os caracteres (da qual se falou acima), enquanto Madalena dialoga com Deus: "A DUQUESA - E que é um instante para vós que ficais desfrutando a vida?... Por Deus! Dai-me um só instante!" 597

\begin{abstract}
MADALENA - Oh, Deus, senhor meu! Pois já, já! nem mais um instante, meu Deus? Cruz do meu Redentor, ó cruz preciosa, refúgio de infelizes, ampara-me tu, que me abandonaram todos neste mundo, e já não posso com as minhas desgraças... e estou feita um espetáculo de dor e de espanto para o céu e para a terra! Tomai, Senhor, tomai tudo... A minha filha também?... Oh, a minha filha, a minha filha... também essa vos dou, meu Deus. E agora, que mais quereis de mim, Senhor?
\end{abstract}

Se atentarmos para o fato de se tratarem de obras modernas, no sentido de que se apropriam de uma concepção histórica pautada na mudança ${ }^{598}$, da qual nos fala Octavio Paz em Os filhos do barro, fica ainda mais evidente que o trágico aqui não se coaduna com a ideia de intervenção arbitrária, mas com a tragicidade inerente ao tempo social e à história:

\begin{abstract}
Suspeitamos que a tragédia de ontem, como o drama de hoje, seja apenas mais uma das estratégias ocidentais de racionalização do trágico. É certo que a tragédia investe o que pode na representação de tragicidade, explorando-a sob vários aspectos, expondo situações terríveis que nos induzem sem maiores pudores à dor e ao sofrimento. Contudo, esse mergulho no trágico não significa, entendemos, um afogamento no trágico, um perder-se no absurdo da dor inexplicável. Algo nos diz que a construção ficcional da tragédia, ao tempo que acolhe o trágico, ao inseri-lo em uma ordem lógicoracionalista, produz rasuras severas na concepção de trágico como intervenção fatalística incompreensível, inesperada ou imerecida de uma ordem imprevisível, arbitrária e, portanto absurda. ${ }^{59}$
\end{abstract}

Em Maria, a filha de Madalena e d. Manuel, a fragilidade e vulnerabilidade feminina são reafirmadas, já que, socialmente, sendo mulher e filha ilegítima, ela não teria lugar. A solução para a personagem também é a morte, recurso ordinário na literatura romântica. É interessante contrastar com o drama da duquesa de Bragança, pois, tendo filhos do sexo masculino, ela se sente aliviada, já que preferiria matar a filha

\footnotetext{
597 DIAS, Gonçalves. Op. Cit., p. 967.

598 “A modernidade é sinônimo de crítica e se identifica com a mudança; não é afirmação de um princípio atemporal, mas desdobramento da razão crítica que incessantemente se questiona, se examina e se destrói para renascer mais uma vez." PAZ, Octavio. Op. Cit., p. 37.

${ }^{599}$ LUNA, Sandra. Arqueologia da ação trágica: o legado grego. João Pessoa: Idéia, 2005, p. 33-34 apud Danielle Dayse Marques, Op. Cit., p.104-105.
} 
a deixá-la a mercê de uma sociedade tão temerária e opressora para as mulheres.

A DUQUESA - [...] Deus foi misericordioso para comigo em me não ter dado uma filha; que se eu a tivesse, por muito que a amasse, e ainda que ela fosse a única... meu Deus! Cometeria hoje um crime... matava-a... seria talvez condenada por toda a eternidade, porém, ela seria livre no céu! ${ }^{600}$

Curiosamente os dois dramas aludem ao romance de Bernardim Ribeiro, História de Menina e Moça ${ }^{601}$, reportando-se ao seguinte trecho: "Menina e moça me levaram de casa de minha mãe para muito longe... ${ }^{602}$. Em Garrett a referência a essa passagem do romance de Bernardim é nomeada pela personagem Maria, permitindo ao espectador/leitor associar a fala à obra com a qual se relaciona, ("MARIA: - 'Menina e moça me levaram de casa de meu pai' - é o princípio daquele livro tão bonito que minha mãe diz que não intende; intendo-o eu." ${ }^{903}$ ). Já na peça gonçalvina a menção, mais atenuada e sem designação, está implícita:

\begin{abstract}
A DUQUESA: - (depois de alguns instantes de silêncio) - Criança me trouxeram da casa de meus pais, prenderam-me numa câmara forrada de veludo, envolveram-me em alcatifas de seda, em reposteiros de damasco, e eu disse adeus ao meu prado florido, ao meu jardim encantado, às flores que eu amava, a tudo, um padre, a tudo!... ${ }^{604}$
\end{abstract}

Embora seja Maria $^{605}$ quem se refira ao texto seiscentista, acenando para a repentina mudança de casa, a citação pode ser estendida à história de sua mãe. Madalena assinala em conversa com Telmo Pais como casara cedo, criança ainda, e que com dezessete anos, após a terrível batalha no Marrocos, já era viúva e órfã. O primeiro

${ }^{600}$ DIAS, Gonçalves. Op. Cit., p. 957.

${ }^{601}$ O romance foi editado três vezes durante o século XVI, em Ferrara (1554), em Évora (1557-58) com o título de Saudades, e em Colônia (1559). Devido às diferentes edições e acréscimos posteriores, ainda há discussões sobre a fixação do texto. Considerada uma novela sentimental, a obra abarca elementos das novelas de cavalaria e dos romances pastoris. O texto inicia-se com as lamentações de cunho fatalista da Menina, cujos infortúnios não são narrados claramente. Assim, pode-se apenas inferir os motivos de sua descrença. A ela junta-se a Dona dos tempos antigos que também se queixa de suas desventuras e da condição das mulheres, inevitavelmente tristes. A seguir, essa personagem conta três narrativas de amor e morte em que predominam os sentimentos de tristeza e saudade. As histórias de: Lamentor e Belisa, Aónia e Binmarder, e Avalor e Arima.

${ }^{602}$ RIBEIRO, Bernardim. História de Menina e Moça. Reprodução facsimilada da edição de Ferrara, 1554. Lisboa: Fundação Calouste Gulbenkian, 2002, Aii.

${ }^{603}$ GARRETT, Almeida. Op. Cit., p. 89.

${ }^{604}$ DIAS, Gonçalves. Op. Cit., p. 961.

${ }^{605}$ Vale lembrar que a citação feita por Maria serve também para a complexão dessa personagem, que tem sido descrita como um caracter idealizado pela crítica por suas atitudes e conhecimentos elevados, ou melhor, não condizentes com uma criança. 
casamento, em termos sentimentais, fora insatisfatório, porque d. Madalena não amava d. João.

As narrativas de Madalena e de Leonor têm claramente pontos em comum, a infância de ambas é abortada para assumirem um casamento sobre o qual não tiveram escolha e não puderam objetar. A intertextualidade, levando em conta o teor do início do texto bernardiniano em que há ênfase na tristeza e solidão das mulheres, serve para adensar o sofrimento dos caracteres femininos em ambas as peças. As três obras literariamente trabalham a representação da sensibilidade feminina de uma forma bastante subjetiva imprimindo lirismo e poeticidade aos textos.

\begin{abstract}
Porque o pouco tempo que há que vivo, tenho aprendido que não há tristezas nos homens. Só as mulheres são tristes: que as tristezas, quando viram que os homens andavam de um cabo para outro, e como as mais das cousas, com as contínuas mudanças, ora se espalham, ora se perdem, e as muitas ocupações lhe tolhiam o mais do tempo, tornaram-se às coitadas das mulheres, ou porque aborreceram as mudanças, ou porque elas não tinham para onde lhes fugir. ${ }^{606}$
\end{abstract}

Cabe destacar ainda que o trecho ao qual Leonor de Mendonça e Frei Luís de Sousa se referem abre o romance de Bernardim Ribeiro e determina o teor fatalista da novela, característica que perpassa os dramas românticos em questão reverberando a temática de amor e morte. Aliás, as duas peças, assim como a História de Menina e Moça, principiam com falas cujo sentido prenuncia as desgraças vindouras.

Depois desse longo parêntese confrontando Frei Luís de Sousa e Leonor de Mendonça, parece arrazoado comentar a obra de outro dramaturgo em cena no Brasil do século XIX. Vale lembrar que esse procedimento se coaduna com a proposta exposta na introdução deste trabalho de comparar o drama gonçalvino com os de outros autores brasileiros coetâneos para melhor compreender a especificidade da peça em questão.

Os (melo)dramas de Luís Antônio Burgain, à época, foram bastante privilegiados pela crítica e pelo público ${ }^{607}$. Em a Casa Maldita, ou A Mocidade de Affonso VI - Drama em IV actos - representado em 1853608, Burgain dosa cenas

${ }^{606}$ RIBEIRO, Bernardim. Op. Cit.

${ }^{607}$ FARIA, João Roberto. O Teatro na Estante. Cotia, SP: Ateliê Editorial, 1998, p. 26.

${ }^{608}$ Carlos apaixona-se por Clemência sobrinha do usurário Diogo e decide trabalhar como caixeiro na casa deles. No entanto, com essa resolução o apaixonado corre sério risco, já que a casa onde reside sua amada é conhecida por suas histórias de morte e desgraça. Diogo, por exemplo, já tivera outros dois jovens caixeiros morando com ele, os quais foram acusados de roubo. Considerados culpados, o primeiro morreu no patíbulo e o segundo se suicidou. Os pertences roubados nunca foram encontrados e os acusados eram provavelmente inocentes. Todos os moradores da casa estavam trancados em seus quartos no momento do crime, pois Diogo, terrivelmente mesquinho, os trancafiava à noite, temendo que seu 
cômicas com um enredo que envolve mistério e um entrecho amoroso, tudo isso misturado a um pano de fundo histórico pitoresco (as arruaças do infante Afonso VI, filho de d. João IV de Portugal). Os recursos melodramáticos são utilizados em demasia, como na suposta existência de entes sobrenaturais e o duelo de espadas entre Carlos e o Infante. Mesmo o mistério que envolve a casa maldita e os empecilhos que impedem a união dos namorados Carlos e Clemência são tão pouco profundos e resolvem-se de forma tão espontânea e abrupta que beira o inverossímil, resultando num efeito muito mais próximo do cômico ${ }^{609}$. Aliás, pode-se dizer que a peça de Burgain apresenta alguns aspectos da comédia de personagem, como a ênfase na avareza de Diogo da Silva de forma estereotipada. A linguagem é dinâmica e irônica, não faltando nem mesmo o emprego de quiproquós e ditados populares nas extensas falas concedidas ao serviçal Gorduxo. Tal combinação faz com que a peça privilegie o entretenimento, embora haja nela uma lição moral inerente. Enquanto em Leonor de Mendonça o efeito trágico é incisivo, em A Casa Maldita, o conflito apresenta-se tão diluído que o sofrimento das personagens soa bastante superficial. Gonçalves Dias evita introduzir trechos risíveis. Basta comparar a diferença entre a concessão ao caricato dado à Paula e a forte incidência desse aspecto nos diálogos entre Gorduxo e as outras personagens de A Casa Maldita.

tesouro fosse descoberto e debilitado. Clemencia é disputada por três homens, o médico do tio, Tibúrcio, Carlos, o caixeiro e pelo infante D. João IV. Ela ama Carlos que, como os outros caixeiros, acaba sendo acusado de roubo. O desenlace é feliz. Descobre-se que o ladrão misterioso é próprio dono do tesouro. Diogo escondia os produtos durante ataques de sonambulismo. Carlos escapa da execução por intercessão de seu antigo rival, D. Afonso VI. Diogo se arrepende de suas ações passadas e abre mão de sua fortuna. BURGAIN, Luiz Antonio. A Casa Maldita ou A Mocidade de Affonso VI, Rio de Janeiro: Eduardo \& Henrique Laemmert, 1867.

${ }^{609}$ Hessel e Raeders observam esse mesmo viés cômico na obra Pedro Sem, Que já teve e agora não tem: “(...) a classificação de drama não assenta muito bem à obra, dado que ela está povoada de cenas hilariantes e até cômicas, de conversas fiadas, tudo isso ocupando o lugar e o tempo de cenas comoventes, tensas, dramáticas, mais consentâneas com o gênero.” HESSEL, Lothar; RAEDERS, Georges. Op. Cit., p. 48 . 


\section{CONSIDERAÇÕES FINAIS}

A grande obra de arte é inesgotável em termos conceituais; estas só podem aproximar-se dos significados mais profundos. O essencial revela-se, em toda a sua forma imediata, somente à própria experiência estética.

Anatol Rosenfeld

Essa epígrafe expressa de forma bastante exata o que se experimenta ao término deste trabalho. As inúmeras leituras da obra, os estudos teóricos e as comparações com outras peças não abarcaram a profundidade de Leonor de Mendonça. A cada nova leitura, novas nuances de sentido são percebidas, e mais prazerosa a leitura se torna. Consciente das limitações da presente análise, não se poderia apresentar um final de cunho conclusivo, mas apenas algumas considerações sobre o exposto a fim de esclarecer as questões mais relevantes discutidas anteriormente.

O estudo privilegiou o contexto estético em que a peça Leonor de Mendonça foi produzida. Para tanto se valeu da comparação com outros textos coetâneos que versavam sobre a escrita romântica, comentando as aproximações e diferenças com a proposta gonçalvina. Nesse exercício também se ponderou que, no Brasil, a rec da estética romântica foi tardia e mediada pela acepção que os escritores franceses deram às produções inglesas e alemãs. Vale lembrar que tal conjuntura se diferencia no caso de Gonçalves Dias, que recebeu os influxos da nova estética primeiramente via Portugal e, em seguida da Alemanha, lendo muitos textos na versão original, já que conhecia o alemão, o inglês e o italiano. A sua relação com a estética romântica reverbera, conforme o estudo do Prólogo a Leonor de Mendonça e outros textos em que ele discute o fazer artístico, na assunção de que a escrita é o resultado de um processo interno e subjetivo e que a natureza serve para desencadear a imaginação. Outrossim, Dias estava perto da atualidade europeia e da voga medievalista coimbrã, tornando-se leitor de crônicas que serviriam como inspiração artística em acordo com a relação entre o romantismo e o interesse pela história, a qual é vista pela perspectiva organicista.

A tese também se valeu de análises comparativas que confirmaram o espírito cosmopolita de G. Dias, o qual estabeleceu diálogos com diferentes obras e autores, demonstrando grande interesse em compreender a estética romântica e aplicá-la na poesia e no teatro. 
Os estudos de Literatura Comparada aqui desenvolvidos tiveram por escopo apresentar as relações estéticas entre Gonçalves Dias e o teatro europeu, especialmente com os dramas hugoanos e schillerianos. Nessas confrontações, procurou-se também demonstrar que, apesar de dialogar sobretudo com esses dois autores, o dramaturgo brasileiro havia absorvido outras experiências estéticas advindas do drama histórico português e da ópera italiana. Tais análises valeram-se das características intrínsecas aos textos em detrimento de uma visão pautada pela noção de influência. Ademais, levandose em conta que a literatura ocidental compõe-se de um grande número de interrelações ${ }^{610}$, a ideia é refletir sobre a afinidade de Leonor de Mendonça com outras obras mesmo que não tenha havido uma relação direta. Por fim, as confrontações com os dramas e tragédias brasileiros coetâneos serviram para ajuizar a singularidade e a importância de L.M. para a dramaturgia desse período.

Em referência ao diálogo com a obra teatral de Friedrich Schiller, considerando os estudos prévios de Jacobbi e Volobuef e a comparação entre Leonor de Mendonça e Maria Stuart, bem como a noção de tragicidade em A Noiva de Messina, entende-se que o conflito em Gonçalves Dias estrutura-se no conflito social, enquanto em Friedrich Schiller o embate é interior. A diferença, todavia, se dá pela proeminência, pois é o contexto histórico em Maria Stuart que coloca a protagonista diante do conflito que é, no entanto, resolvido interiormente, na luta entre os desejos naturais e os espirituais, os quais se sobressaem derrotando os impulsos sensíveis. A duquesa gonçalvina também apresenta conflitos internos, mas que reverberam a questão social da submissão das mulheres na sociedade patriarcal que a impede de fruir seus sentimentos e desejo. Dessa forma, para ambos os autores a história é o lugar em que se dá a fatalidade. No caso de Schiller, os exemplos históricos servem como um paradigma para que aprendamos a nos apegar à liberdade moral. Em Dias, o fato histórico não serve como modelo de superação do sensível e nem mesmo para fins políticos, como mormente se observa nos dramas históricos franceses. O fatum gonçalvino aproxima sua obra do drama romântico ao esboçar certo determinismo social encenando questões sociais sem, contudo, apresentar propostas filosóficas ou soluções políticas.

De qualquer maneira, não se pode desprezar a importância da produção schilleriana para o desenvolvimento do teatro de Gonçalves Dias que transparece de forma mais determinante na eleição da história como acervo de exemplos em que o

${ }^{610}$ WELLEK, René. Op. Cit., 2011, p. 121. 
homem é colocado em conflito, no uso de uma linguagem elevada e na adesão à estrutura da tragédia clássica no que concerne principalmente à simplicidade do enredo e à inclusão de poucas personagens, bem como à condensação das ações ${ }^{611}$. Essas características provocam o adensamento do conflito de forma crescente até o desfecho trágico.

A indubitável relação com a dramaturgia de Victor Hugo já fica evidenciada no Prólogo, onde, mais de uma vez o autor francês é citado. Na introdução é possível relacionar a fatalidade gonçalvina com a expressão de "uma verdade incisiva e áspera," proposta por Hugo, bem como compreender a inclusão de cenas cotidianas (cômicas) que promovem a quebra da gravidade da tragédia com base em exemplos de produções hugoanas, especificamente a Lucrécia Bórgia. No entanto, como se viu anteriormente, "a verdade" hugoana se vincula ao propósito de educar as massas por meio do teatro, pois, as lições que o drama expõe são severas e contundentes. Já a "verdade" gonçalvina expõe o rigor das arbitrariedades sociais que tolhe, desvirtua ou perde o sujeito, aproximando-se, em parte, da tragicidade schilleriana. Observou-se também que a presença de Hugo não se restringe ao Prólogo. Leonor de Mendonça retoma várias temáticas, ou melhor, críticas sociais aventadas pelo dramaturgo francês em suas peças, como a questão da submissão feminina, o questionamento da superioridade da nobreza, as consequências das desigualdades e marginalizações, as quais são sempre apresentadas num evento passado como previa o drama histórico. Aliás, mais do que isso, parece haver um intrínseco diálogo da peça goncalvina com todos os dramas de Victor Hugo produzidos entre 1833 e 1838. A incorporação da teoria do drama do escritor francês não se limita a inclusão da famosa cena na casa de Antônio Alcoforado. A composição das personagens, por exemplo, se pauta na justaposição de opostos, no sublime e no grotesco. Assim, os caracteres abarcam predicados cômicos e trágicos a fim de garantir que a ideia exposta no drama não seja prejudicada por ser demasiado grande ou muito ordinária e consiga expressar o grande e o verdadeiro. Ainda com referência ao diálogo com Hugo, viu-se que a teoria de Ubersfeld sobre a oposição entre os espaços nos dramas hugoanos, a qual observa que a personagem marginalizada é punida por tentar adentrar o espaço do poder, pode ser empregada para pensarmos

${ }^{611}$ Segundo Hessel e Raeders: Além disso, num volume do Teatro de Schiller, consultado na Biblioteca da Universidade [de Coimbra], Gonçalves Dias deve ter descoberto não só o drama Die Braut Von Messina, como ainda a trilogia do Wallenstein. Nesses dramas estudou e admirou os tipos de estrutura, como o fizera com o teatro de Almeida Garrett. 
Leonor de Mendonça. Desse modo, este estudo confirmou e somou outros aspectos da relação entre os dois dramaturgos românticos apontando outros pontos de incidência estética.

Como primeiramente apontou Prado, a peça também exibe aspectos que lembram o realismo flaubertiano quando problematiza o amor romântico apresentando uma duquesa que se interessa pela possibilidade de um envolvimento amoroso e, imprudente, coloca sua vida e a do apaixonado em risco. Ela não demonstra ou confessa sentir amor, amor romântico, como Alcoforado. Ela deseja fruir a vida, por isso sente necessidade de encontrar algum prazer na existêcia isolada em Vila Viçosa.

Sopesaram-se também as afinidades entre Leonor de Mendonça e a tragédia doméstica, pois, embora dois dos protagonistas desse drama sejam nobres, a ação não acarreta consequências para o Estado, o conflito permanece no âmbito familiar. Como em seu precursor, os sentimentos e os direitos individuais são valorizados, especialmente o da escolha do cônjuge. Pode-se argumentar ainda que no drama sério o meio social também é destacado, mas não impulsiona a tragédia. Em geral, no drama burguês uma personagem age de forma irracional, em desacordo com a virtude burguesa, provocando sua própria desgraça. Há também os enredos que criticam os valores da nobreza e enaltecem os princípios burgueses, estabelecendo um conflito dos bons contra os maus. Dessa forma, L.M. descende da mesma linha dramática, mas incorpora as pretensões do drama romântico ao criticar não a ação de uma personagem, mas o mecanismo social que envolve todos os caracteres. Nesse sentido, tanto os erros cometidos pela duquesa como o seu assassinato decorrem das conjunturas históricosociais, e não de uma falha moral, o que faz com que a peça também se diferencie da tragédia clássica, pois o fatum dos heróis clássicos não é condicionado pelas regras da sociedade.

Ao longo do trabalho outros gêneros foram revisitados a fim de conhecer a "ascendência" do drama em questão e suas relativas características. Esse exercício aclarou, por exemplo, o que Jacobbi chamou de "byronismo de temática neoelisabetiana" presente em Leonor de Mendonça. Como muitos dramas históricos e melodramas coetâneos, Gonçalves Dias assimilou algumas características da literatura gótica que se refletem na conformação das personagens, do espaço e do tempo. $\mathrm{O}$ viés opressivo e lúgubre nos caracteres pode ser vislumbrado na obsessão por autodestruição em Alcoforado, na violência e melancolia do Duque e na submissão de Leonor que a perfaz em vítima. Além disso, Dias incorpora incidentes da infância das personagens a 
fim de delinear suas personalidades e justificar certas ações. A atmosfera é fortemente marcada nas falas e vaticínios que antecipam os infortúnios. O palácio ducal, isolado e de difícil acesso denota a ideia de enclausuramento, de impossibilidade de saída, de fatalidade. E, definitivamente, não há saída desse espaço para a duquesa e Alcoforado. No que tange ao tempo, vale lembrar que o encontro entre a nobre e o jovem fidalgo acontece à meia-noite, no dia de finados: uma noite encoberta de trevas perpassada pelo som dos dobres. Pode-se dizer que o uso dessa ambiência gótica é a maior concessão feita aos clichês melodramáticos, pois, conforme exposto anteriormente, o dramaturgo evitou desenvolver um enredo baseado no efeito moralizante, com elementos complicadores como os subenredos e coups de théâtre.

Se pensarmos em suas características gerais, ou melhor, para efeitos didáticos, Leonor de Mendonça pode ser considerado um drama histórico. Mas uma análise mais detida mostra a complexidade da obra que se estrutura na inter-relação entre características de diferentes gêneros que, de forma surpreendente, se coadunam de maneira a tornar a peça singular. Diferentes experiências estéticas do autor foram subsumidas atuando na composição das ações e das personagens principais que, em conjunto, conformam efetividade dramática e simbólica, além da crítica social. Dito de outra maneira, ao condensar a teoria do drama romântico à fatalidade de cunho social e à concisão da tragédia, matizando-as com elementos da literatura gótica, a peça deu força e profundidade à história de Leonor, conglobando presente e passado, o elemento eterno ao humano, o elemento social ao histórico ${ }^{612}$, ciente de que:

[...] o drama segundo o século XIX, não é a tragicomédia altaneira, desmesurada, espanhola e sublime de Corneille; não é a tragédia abstrata, amorosa, ideal e discretamente elegíaca de Racine; não é a comédia sagaz, profunda, penetrante, mas impiedosamente irônica, de Molière; não é a tragédia com intenção filosófica de Beaumarchais; não é mais do que tudo isso, mas é tudo isso a um só tempo; ou para melhor dizer, não é nada de tudo isso. Não é, como entre os grandes homens, um só lado das coisas, sistematicamente e perpetuamente exposto à luz, é tudo olhado a um só tempo sob todas as faces. Se houvesse hoje um homem que pudesse realizar o drama como nós o compreendemos, esse drama seria o coração humano, a cabeça humana, a vontade humana; seria o passado resuscitado em benefício do presente; seria a história que nossos pais fizeram e confrontada com a história que nós fazemos; seria essa mistura, no palco, de tudo o que está misturado na vida; ${ }^{613}$

${ }^{612}$ HUGO, Victor. Prefácio a Angelo. In: Op. Cit., p. 157.

${ }^{613}$ Idem, Prefácio a Maria Tudor. In: Op. Cit., p. 11. 


\section{REFERÊNCIAS BIBLIOGRÁFICAS}

ABDALA JUNIOR, Benjamin. Literatura, História e Política: Literaturas de Língua Portuguesa no Século XX. 2 ed., Cotia, SP: Ateliê Editorial, 2007.

ABRAMS, M.H. O Espelho e a Lâmpada: teoria romântica e tradição crítica. Trad. Alzira Vieira Allegro. São Paulo: Editora Unesp, 2010.

AGUIAR, Flávio (Org.). Antologia do teatro brasileiro: o teatro de inspiração romântica. São Paulo: SENAC São Paulo, 1998.

AGUIAR e SILVA, Vítor Manuel de. Teoria da Literatura. 8. ed., vol. I, Coimbra: Livraria Almedina, 2006.

ALAVARCE, Camila da Silva. A ironia e suas refrações: um estudo sobre a dissonância na paródia e no riso. São Paulo: Cultura Acadêmica, 2009.

ALMEIDA, Rafael Loureiro de. Martins Pena: narrativas e arquétipos do teatro romântico brasileiro. Rio de Janeiro, 2012, Dissertação de Mestrado. Programa de pósgraduação em Letras Vernáculas. Universidade Federal do Rio de Janeiro.

ANDRADE, Carlos Drummond de. O Sorriso de Gonçalves Dias. In: Confissões de Minas. São Paulo: Cosac Naify, 2011, p. 37-44.

ARAÚJO, Jorge de Souza. Gonçalves Dias: a clave e a clava. In: Retrós de espelhos: o romantismo brasileiro com lentes de aumento. Ilhéus, BA: Editus, 2011, p. 119-127.

ARÊAS, Vilma Sant'Anna. Na Tapera de Santa Cruz: uma leitura de Martins Pena. São Paulo: Martins Fontes, 1987.

A Comédia no Romantismo Brasileiro: Martins Pena e Joaquim Manoel de Macedo. Novos Estudos - CEBRAP, São Paulo, n. 76, novembro. 2006. Disponível em: $<$ http.www.scielo.br $>$. Acesso em 20/04/2014.

. Variações do "amor cortês" em Leonor de Mendonça e em O casamento de Fígaro. Teresa revista de Literatura Brasileira. Universidade de São Paulo, São Paulo: Ed. 34, n. 12-13, 2013, p. 226-242.

ARISTÓTELES. Poética. Trad. e notas de Eudoro de Sousa. Lisboa: Guimarães Editores, 1964..

ASSIS, Machado de. Obras Completas de Machado de Assis: Críticas Teatrais. 6. vol., São Paulo: Editora Formar, s/d

AUERBACH, Erich. Mimesis: a representação da realidade na literatura ocidental. 5. ed., São Paulo: Perspectiva, 2004. 
. Vico e o historicismo estético. In: Ensaios de Literatura Ocidental: Filologia e Crítica. 2. ed., São Paulo: Duas Cidades; Editora 34, 2012, p. 341-356.

AZEVEDO, J. Lúcio. Épocas de Portugal Econômico. 4. ed., Lisboa: Clássica Editora, 1978.

BANDEIRA, Manuel. In: Centro Cultural Banco do Brasil. Banco do Brasil apresenta e patrocina a peça Maria Stuart de Schiller. 2009

BASTOS, Alcmeno. Introdução ao romance histórico. Rio de Janeiro: EdUERJ, 2007.

BARBOSA, Ricardo. A especificidade do estético e a razão prática em Schiller. Kriterion: Revista de Filosofia. v. 46, n. 112, Belo Horizonte, Dec. 2005.

BATAILLE, Georges. A literatura e o mal. Trad. Suely Bastos. Porto Alegre: L\&PM, 1989.

BÉCQUER, Gustavo Adolfo. Cartas literárias a uma mulher. In: PALMA, Anna; CHIARINI, Ana Maria; TEIXEIRA, Maria Juliana Gambogi. O Romantismo Europeu: antologia bilíngue. Belo Horizonte: Autêntica Editora, 2013, p. 192-221.

BELLINI, Vincenzo. Norma. Libreto italiano de Felice Romani baseado no drama homônimo de Alexandre Soumet. Lisboa: Editorial Notícias. Introd., análise e comentários Gonzalo Badenes Maso, s/d.

BÉNAC, Henri. O Romantismo Francês. Organon, v. 8, n. 8-9, 1963.

BENJAMIN, Walter. Origem do drama trágico alemão. Ed. e trad. João Barrento. Belo Horizonte: Autêntica, 2011.

BERCHET, Giovanni. Carta semisséria de Grisóstomo a seu filho. Trad. e notas Ana Maria Chiarini. In: PALMA, Anna; CHIARINI, Ana Maria; TEIXEIRA, Maria Juliana Gambogi. O Romantismo Europeu: antologia bilíngue. Belo Horizonte: Autêntica Editora, 2013, p. 43-87.

BERRENTINI, Célia. Introdução. In: HUGO, Victor. Do grotesco e do sublime: tradução do Prefácio de Cromwell. Trad. Célia Berrettini. São Paulo: 2004.

BORNHEIM, Gerd. Filosofia do Romantismo. In: GUINSBURG, J. (Org.). $O$ Romantismo. São Paulo: Perspectiva, 1985, p. 75-111.

BOWRA, C.M. La imaginación romántica. Trad. José Antonio Balbotín. Madrid: Taurus, 1972.

BRAGA, Cláudia. Melodrama: aspectos gerais do gênero matriz da telenovela. Intercom - Sociedade Brasileira de Estudos Interdisciplinares da Comunicação. Anais. XXVIII Congresso Brasileiro de Ciências da Comunicação. Rio de Janeiro. UERJ. 5 a 9 de set. de 2005 . 
BRAGANÇA, Maurício de. Melodrama: notas sobre a tradição/tradução de uma linguagem revisitada. Eco-Pós, v. 10, n. 2, jul.-dez. 2007, p. 29-47.

BRILHANTE, Maria João. Caminhos da herança clássica até ao teatro francês contemporâneo. Máthesis, Viseu, n.12, 2003, p.199-231.

Figurações do Feminino em Frei Luís de Sousa de Almeida Garrett.

Universidade Aberta, 2006. Disponível em

$<\underline{\text { https://repositorioaberto.uab.pt/bitstream/10400.2/405/1/discursosAlmeidaGarrett31- }}$

51.pdf.pdf>. Acesso em 20 jan. 2014.

BRONTË, Emily. O morro dos ventos uivantes. Trad. Raquel de Queiroz. São Paulo: Abril, 2010.

BURGAIN, Luiz Antonio. A Casa Maldita ou A Mocidade de Affonso VI. Rio de Janeiro: Eduardo \& Henrique Laemmert, 1867.

BURKE, Edmund. Uma investigação filosófica sobre a origem de nossas ideias do sublime e do belo. Trad., apres. e notas Enid Abreu Dobránszky, Campinas, SP: Papirus: Editora da Universidade de Campinas, 1993.

CACCIAGLIA, Mario. Pequena história do teatro no Brasil: quatro séculos do teatro no Brasil. São Paulo: T.A. Queiroz; EDUSP.

CAMILO, Vagner. Risos entre Pares: poesia e humor românticos. São Paulo: Editora da Universidade de São Paulo; Fundação de Amparo à Pesquisa do Estado de São Paulo, 1997.

CAMÕES, Luís. Os Lusíadas. Prefácio e notas Hernani Cidade. São Paulo: Círculo do Livro, s/ data.

CANDIDO, Antonio. Formação da Literatura Brasileira: momentos decisivos (18361880), Vol. II, São Paulo: Livraria Martins Editora, 1964.

CARLSON, Marvin. Teorias do teatro: estudo histórico-crítico, dos gregos à atualidade. Trad. Gilson César Cardoso de Souza. São Paulo: Fundação Editora da UNESP, 1997.

CECCHINI, Gisele Molon. Lucrécia Bórgia: um drama no oceano de Victor Hugo. v. 1, Dissertação de Mestrado, PUC do Rio Grande do Sul, Porto Alegre, 2009.

CHARTIER, Roger. Formação social e economia psíquica: a sociedade de corte no processo civilizador (Prefácio). Trad. André Telles. In: ELIAS, Norbert. A sociedade de corte: investigação sobre a sociologia da realeza e da aristocracia de corte. Trad. Pedro Süssekind. Rio de Janeiro: Zahar, 2001, p. 7-25. 
CODE CIVIL DES FRANÇAIS - Titre V - Chapitre VI. Disponível em: <

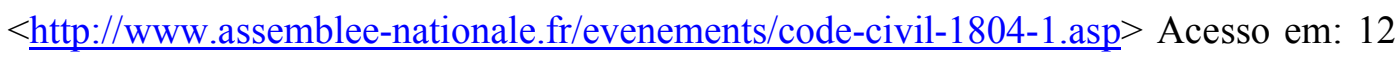
out. 2014.

COLERIDGE, Samuel Taylor. Biografia Literária. Trad. e notas Julio Jeha. In: PALMA, Anna; CHIARINI, Ana Maria; TEIXEIRA, Maria Juliana Gambogi. $O$ Romantismo Europeu: antologia bilíngue. Belo Horizonte: Autêntica Editora, 2013, p. 88-114.

CORREIA, Marlene de Castro. O teatro de Gonçalves Dias. In: DIAS, Antônio Gonçalves. Teatro Completo. Rio de Janeiro: Serviço Nacional de Teatro, 1979.

CUNHA, Cilaine Alves. Introdução. In: DIAS, Gonçalves. Cantos. São Paulo: Martins Fontes, 2001, p. IX-LXI.

DIAS, Daise Lílian Fonseca. O erro trágico de Cathy em O morro dos ventos uivantes. In: XII Seminário Nacional e III Seminário Internacional Mulher e Literatura - Gênero, Identidade e Hibridismo Cultural, 12, 2007, Ilhéus, Anais do XII Seminário Nacional e III Seminário Internacional Mulher e Literatura, Ilhéus, BA: UESC/ Editus. Disponível em:

$<$ http://www.uesc.br/seminariomulher/anais/PDF/DAISE\%20LILIAN\%20FONSECA\% 20DIAS.pdf $>$. Acesso em: 20 ago. 2013.

DIAS, GONÇALVES. Primeiros Cantos. In: BUENO, Alexei. (Org.). Gonçalves Dias: poesia e prosa completas. Rio de Janeiro: Nova Aguilar, 1998, p. 101-217.

. Segundos Cantos. In: BUENO, Alexei. (Org.). Gonçalves Dias: poesia e prosa completas. Rio de Janeiro: Nova Aguilar, 1998, p. 219-296.

. Sextilhas de Frei Antão. In: BUENO, Alexei. (Org.). Gonçalves Dias: poesia e prosa completas. Rio de Janeiro: Nova Aguilar, 1998, p. 297-366.

. Patkull. In: BUENO, Alexei. (Org.). Gonçalves Dias: poesia e prosa completas. Rio de Janeiro: Nova Aguilar, 1998, p. 781-839.

. Beatriz Cenci. In: BUENO, Alexei. (Org.). Gonçalves Dias: poesia e prosa completas. Rio de Janeiro: Nova Aguilar, 1998, p. 841-899.

. Leonor de Mendonça. In: BUENO, Alexei. (Org.). In: Gonçalves Dias: poesia e prosa completas. Rio de Janeiro: Nova Aguilar, 1998, p. 901-969.

- Boabdil. In: BUENO, Alexei. (Org.). Gonçalves Dias: poesia e prosa completas. Rio de Janeiro: Nova Aguilar, 1998, p. 971-1032.

. Correspondência. In: BUENO, Alexei. (Org.). Gonçalves Dias: poesia e prosa completas. Rio de Janeiro: Nova Aguilar, 1998, 1033-1144. 
DIDEROT, Denis. Discurso sobre a poesia dramática. Trad. org. apres. e notas Franklin de Mattos. 2. ed., São Paulo: Cosac Naify, 2005.

. O filho natural ou as provações da virtude: conversas sobre o filho natural.

Trad. e notas Fátima Saadi. Org. J. Guinsburg. São Paulo: Perspectiva, 2008.

D’INCAO, Maria Ângela. Mulher e família burguesa. In: DEL PRIORE, Mary. (Org.).

História das mulheres no Brasil. 8. ed., São Paulo: Contexto, 2006, p. 223-240.

DUARTE, Pedro. Estio do tempo: Romantismo e estética moderna. Rio de Janeiro: Zahar, 2011.

DUMAS, Alexandre. Antony. Paris: Collombon et Brûlé, s.d.

EAGLEtON, Terry. A ideologia da estética. Trad. Mauro Sá Rego Costa. Rio de Janeiro: Jorge Zahar Editor, 1993.

ELIAS, Norbert. A sociedade de corte: investigação sobre a sociologia da realeza e da aristocracia de corte. Trad. Pedro Süssekind. Rio de Janeiro: Zahar, 2001.

. A peregrinação de Watteau à ilha do amor: seguido de seleção de textos sobre Watteau. Rio de Janeiro: Jorge Zahar, 2005.

. O processo civilizador: uma história dos costumes. vol. I, 2. ed., Trad. Ruy Jumgmann, Rio de Janeiro: Zahar, 2011.

ESSLIN, Martin. Uma anatomia do drama. Trad. Barbara Heliodora. Rio de Janeiro: Zahar Editores, 1978.

FARIA, João Roberto. O Teatro na Estante. Cotia, SP: Ateliê Editorial, 1998.

. Ideias teatrais: o século XIX no Brasil. São Paulo: Perspectiva; FAPESP, 2001.

(Dir.). História do Teatro Brasileiro: das origens ao teatro profissional da primeira metade do século XX. Vol. I, São Paulo: Perspectiva: Edições SESCSP, 2012.

. Victor Hugo e o teatro romântico no Brasil. Lettres Françaises, n. 5, 2003, p.

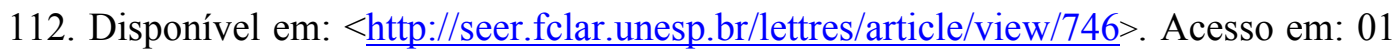
out. 2012.

FELDMAN, Sérgio Alberto. Amantes e Bastardos: as relações conjugais e extraconjugais na alta nobreza portuguesa no final do século XIV e início do século XV.

2. ed., Vitória: EDUFES, 2008.

FREITAG, Barbara. Itinerários de Antígona: a questão da moralidade. 4. ed., Campinas, SP: Papirus, 2005.

GARRETT, Almeida. Frei Luís de Sousa. In: Teatro de Almeida Garrett, vol. III, Lisboa, 1844. 
. Memória ao Conservatório Real. In: GARRETT, Almeida. Frei Luís de Sousa.

Realização didática Luís Amaro de Oliveira. Porto: Porto Editora, 1987, p. 216- 222.

GAUDON, Jean. Introduction. In: HUGO, Victor. Hernani. Edited by John J. Janc. University Press of America, 2014.

GAY, Peter. A paixão terna: A experiência burguesa da Rainha Vitória a Freud. Trad. Per Salter, São Paulo: Companhia das Letras, 1990.

GENeTte, Gérard. Paratextos Editoriais. Trad. Álvaro Faleiros. Cotia, SP: Ateliê Editorial, 2009.

GIMENEZ, Priscila. Martins Pena: crítico-folhetinista. XI Congresso Internacional da ABRALIC: Tessituras, Interações, Convergências. Anais eletrônicos. São Paulo: USP, 2008. Disponível

em://www.abralic.org.br/anais/cong2008/AnaisOnline/simposios/pdf/075/PRISCILA_G IMENEZ.pdf. Acesso em: 04/03/13.

GIRON, Luís Antônio. A bacanal do espírito: Gonçalves Dias folhetinista e a crítica de jornal na primeira geração romântica brasileira. Tese. 668 p., Escola de Comunicações e Artes da Universidade de São Paulo, São Paulo, 2004.

GIUSTI, César. Teoria e Prática dos Prefácios: um estudo sobre Tutaméia. Disponível em: $<$ http://www.cesargiusti.bluehosting.com.br/Litbnk/textos/teorpref.html $>$. Acesso em: 21 mar. 2014.

GOMES, Eugênio. Visões e revisões. Rio de Janeiro: Ministério da Educação e Cultura; Instituto Nacional do Livro, 1958.

GOUHIER, Henri. L'essence du théatre. Paris: Vrin, 1968.

GUERREAU, Alain. Caça. Trad. Vivian Coutinho de Almeida. In: LE GOFF, Jacques; SCHIMITT, Jean-Claude (Coord.). Dicionário Temático do Ocidente Medieval. Coord. de tradução Hilário Franco Junior. Bauru, SP: EDUSC; São Paulo, SP: Imprensa Oficial do Estado, 2002, vol.I.

GUINSBURG, J. Romantismo, Historicismo e História. In: GUINSBURG, J. (Org). $O$ Romantismo. São Paulo: Perspectiva, 1985, p. 14-21.

GUINSBURG, J. Denis Diderot: o espírito das "luzes". São Paulo: Ateliê Editorial, 2001.

HALSALL, Albert W. Victor Hugo and the Romantic Drama. University of Toronto, 1998.

HAN, Younglim. Romantic Shakespeare: from stage to page. New Jersey: Fairleigh Dickinson Univ. Press, 2001. 
HARTMANN, Pierre. Du sublime: de Boileau à Schiller. Strasbourg: Presses Universitaires de Strasbourg, 1997.

HAUSER, Arnold. História social da arte e da literatura. Trad. Álvaro Cabral. São Paulo: Martins Fontes, 1998.

HEGEL, G.W.F. Cursos de Estética: Poesia. Tradução: Marco Aurélio Werle, Oliver Tolle. São Paulo: Editora da Universidade de São Paulo, 2004.

HERCULANO, Alexandre. Carta V: Cyclos ou grandes divisões históricas - Edade Média e Renascimento - Preferencias da edade media. In: Revista Universal Lisbonense: Jornal dos interesses physicos, morais e litterarios. Tomo II, Anno18421843, Lisboa: Imprensa Nacional, 1843.

Futuro Literário de Portugal e do Brasil. In: BUENO, Alexei (Org.). Gonçaves Dias: Poesia e prosa completas. Rio de Janeiro: Nova Aguilar, 1998.

HESSEL, Lothar; RAEDERS, Georges. O Teatro no Brasil sob Dom Pedro II. Porto Alegre: Ed. da Universidade Federal do Rio Grande do Sul; Instituto Estadual do Livro, 1979.

HUGO, Victor. Maria Tudor. In: Obras completas. Trad. Hilário Correia. São Paulo: Editora das Américas, 1960, vol. XXXIX, p. 8-150. . Angelo. In: Obras completas. Trad. Hilário Correia. São Paulo: Editora das Américas, 1960, vol. XXXIX, p. 151-282.

. Ruy Blás. In: Obras completas. Trad. Hilário Correia. São Paulo: Editora das Américas, 1960, vol. XXXIX, p. 353-515.

. Do grotesco e do sublime: tradução do Prefácio de Cromwell. Trad. Célia Berrettini. São Paulo: 2004.

. Lucrécia Bórgia. In: CECCHINI, Gisele Molon. Lucrécia Bórgia: um drama no oceano de Victor Hugo. v. 1, Dissertação de Mestrado, PUC do Rio Grande do Sul, Porto Alegre, 2009.

HUPPES, Ivete. Melodrama: o gênero e sua permanência. Cotia, SP: Ateliê Editorial, 2000.

HUME, Robert D. Gothic versus Romantic: A Revaluation of the Gothic Novel. PMLA. vol. 84, n. 2. Mar., 1969, p. 282-290. Disponível em: $<$ http://www.jstor.org/stable/1261285 $>$. Acesso em: 22 out. 2013.

JACOBBI, Ruggero. Goethe, Schiller e Gonçalves Dias. Porto Alegre: Edições da Faculdade de Filosofia, Série Letras, v. V, 1958. 
KRAUS, Manfred. Aristotle on the arts of the spoken word: correlations between his Rethoric and Poetics. In: PEREIRA, Belmiro Fernandes; VÁRZEAS, Marta (Orgs.). Retórica e Teatro. A palavra em ação. Porto: U. Porto, 2010, p. 95-108.

KILGOUR, Maggie. The Rise of the Gothic Novel. London; New York: Rotledge, 1995. KOSOVE, Joan Lynne Pataky. The 'Comedia Lacrimosa' and Spanish Romantic Drama (1773-1865). London: Tamesis Books, 1977.

LEITES, EDMUND. A consciência puritana e a sexualidade moderna. Trad. Élide Valarini. São Paulo: Brasiliense, 1987.

LESKY, Albin. A tragédia grega. 2. ed.,São Paulo: Perspectiva, 1976.

LIMA, Danielle Dayse Marques. Jane Eyre: drama e tragédia no romance de Charlote Brontë. 2008. 211 f., Dissertação (Mestrado em Letras), Universidade Federal da Paraíba, João Pessoa, 2008.

LIMA, Luiz Costa. Mímesis: desafio ao pensamento. Rio de Janeiro: Civilização Brasileira, 2000.

LIMA, Mariângela Alves de. Introdução: Entre o rigor clássico e o desalinho romântico. In: MAGALHÃES, Gonçalves de. Tragédias. São Paulo: Martins Fontes, 2005.

LUNA, Sandra. Nunca fomos tão antigos: a ação trágica como resistência ao descentramento pós-moderno. Sínteses. UNESP, 2002.

LUTZ, Deborah. The dangerous lover: Gothic villains, Byronism, and the nineteenth century seduction narrative. Columbus: The Ohio State University Press, 2006, p. X.

SOARES, A. J. de Macedo. Tipos literários contemporâneos I: Gonçalves Dias. in: CASTELLO, JOSÉ Aderaldo. Textos que interessam à história do romantismo, vol. II, São Paulo: Conselho Estadual de Cultura; Comissão de Literatura.

MACHADO, Guacira Marcondes. A poética de Victor Hugo: os prefácios da obra poética. Lettres Françaises, n. 5, 2003, p. 49-59.

MACHADO, Roberto. O nascimento do trágico: de Schiller a Nietzche. Rio de Janeiro: Jorge Zahar, 2006.

MAGALDI, Sábato. Panorama do teatro brasileiro. Rio de Janeiro: Serviço Nacional de Teatro; DAC/FUNARTE; Ministério da Educação e Cultura, s.d.

MAGALHÃES, Gonçalves de. Prólogo a Olgiato. In: Tragédias: Antonio José, Olgiato, e Othelo. Rio de Janeiro: Livraria de B.L. Garnier, 1865.

MALTA, Marize. Entre monstros e bibelôs: histórias extraordinárias de coisas ordinárias. Anais, Rio de Janeiro. XIV Encontro Regional da ANPUH: Memória e Patrimônio, 2010. 
MARQUES, W. J. O poema, o prefácio e o diálogo necessário. Revista Letras. Curitiba: Editora UFPR, n. 67, set./dez. 2005.

MARQUES, Wilton José. Gonçalves Dias: o poeta na contramão (literatura e escravidão no romantismo brasileiro). São Carlos: EdUFSCar, 2010.

MARTINS, José Cândido de Oliveira. Para uma sistematização didáctica das leituras interpretativas do Frei Luís de Sousa de Almeida Garrett. In: MONTEIRO, Ofélia Paiva; SANTANA, Maria Helena Santana (Org.). Almeida Garrett, Um Romântico, Um Moderno, vol. II, Lisboa: IN-CM, p. 89-135.

MASO, Gonzalo Badenes. Introdução. In: BELLINI, Vincenzo. Norma. Libreto italiano de Felice Romani baseado no drama homônimo de Alexandre Soumet. Lisboa: Editorial Notícias. Introd., análise e comentários Gonzalo Badenes Maso, s/d.

MATOS, Franklin de. A dramaturgia do quadro. Discurso. São Paulo: Departamento de Filosofia da FFLCH da USP, v. 26, 1996, p. 93-112.

. Libertinagem e Despotismo. In: O Filósofo e o Comediante: ensaios sobre literatura e filosofia na Ilustração. Belo Horizonte: EDUFMG, 2001, p. 217-222.

. Enorme, bárbaro, selvagem: Diderot e o drama. In: DIDEROT, Denis. Discurso sobre a poesia dramática. Trad., org., apres. e notas Franklin de Mattos, 2. ed., São Paulo: Cosac Naify, 2005.

A querela do teatro no século XVIII: Voltaire, Diderot, Rousseau. O que nos faz pensar. Rio de Janeiro: Departamento de Filosofia, PUCRJ, v. 25, ago. 2009, p. 722.

MENON, Maurício César. Figurações do gótico e de seus desmembramentos na Literatura Brasileira de 1843 a 1932. Londrina, 2007. Tese (Doutorado em Letras), Programa de Pós-Graduação em Letras, Universidade Estadual de Londrina.

MONGELLI, Lênia Márcia de Medeiros. A estética da Ilustração: textos doutrinários comentados. São Paulo: Atlas, 1992.

(Coord.). A literatura doutrinária na corte de Avis. São Paulo: Martins Fontes, 2001.

MORETTO, Fúlvia M. L. Victor Hugo e o Romantismo. Lettres Françaises, n. 5, 2003.

BARBOSA, Sidney (Orgs.). Aspectos do teatro ocidental. São Paulo: UNESP, 2006.

MOST, Glenn W. Da tragédia ao trágico. In: ROSENFIELD, Kathrin Holzermayr (org.). Filosofia \& Literatura: o trágico. Rio de Janeiro: Jorge Zahar, 2001, p. 20-35. 
NAUGRETTE, Florence. Le théâtre romantique: histoire, écriture et mise em scène. Paris: Éditions du Seuil, 2001.

NIETZCHE, Friedrich. Introdução à Tragédia de Sófocles. Rio de Janeiro: Jorge Zahar, 2006.

NOVALIS. Pólen: fragmentos, diálogos, monólogos. Tradução, apresentação e notas Rubens Rodrigues Torres Filho. 2. ed. São Paulo: Iluminuras, 2009.

OLIVEIRA, Luís Amaro. Quando as coisas e objectos actuam como personagens. In: GARRETT, Almeida. Frei Luís de Sousa. Realização didática Luís Amaro de Oliveira. Porto: Porto Editora, 1987.

O PANORAMA: Jornal Litterario e Instructivo da Sociedade Propagadora dos Conhecimentos Uteis. Quadros da Historia Portuguesa VII: Morte de D. Leonor Duqueza de Bragança (1512), vol. II, jan. a dez. de 1838, Lisboa: Typographia da Sociedade, 1838.

PAZ, Octavio. Os filhos do barro: do romantismo à vanguarda. Trad. Ari Roitman e Paulina Watch. São Paulo: Cosac Naify, 2013.

PECORARO, Rossano. Filosofia da História. Rio de Janeiro: Jorge Zahar, 2009.

PEIXOTO, Sergio Alves. A consciência criadora na poesia brasileira: do barroco ao simbolismo. São Paulo, 1999.

PENA, Martins. Fernando ou O cinto acusador. In: Teatro de Martins Pena: dramas.

Vol. II. Edição crítica Darcy Damasceno. Rio de Janeiro: Rio de Janeiro, MEC, INL, 1956.

. D. Leonor Teles. In: Teatro de Martins Pena: dramas. Vol. II. Edição crítica Darcy Damasceno. Rio de Janeiro: Rio de Janeiro, MEC, INL, 1956.

PERES, Marcos Flamínio. In: SCHILLER, Friedrich. A noiva de Messina, ou, Os irmãos inimigos: tragédia com coros. Trad. Antônio Gonçalves Dias. São Paulo: Cosac \& Naify, 2004.

. A fonte envenenada: transcendência e história em Gonçalves Dias. São Paulo: Nova Alexandria, 2003.

PINSKY, Jaime; PINSKY, Carla Bassanezin (Org.). História da Cidadania. São Paulo: Contexto, 2013.

PORTUGAL. Código Penal approvado em setembro de 1886, Lisboa: Imprensa Nacional, 1886.

PRADO, Décio de Almeida. João Caetano: o ator, o empresário, o repertório. São Paulo: Perspectiva; EDUSP, 1972. 
O teatro romântico: a explosão de 1830. In: GUINSBURG. J., (Org.). $O$ Romantismo. São Paulo: Perspectiva, 1985.

. Antonio José, de Gonçalves de Magalhães. Revista USP, n. 15, 1992.

. Teatro de Anchieta a Alencar. São Paulo: Perspectiva, 1993.

. O drama romântico brasileiro. São Paulo: Perspectiva, 1996.

. História concisa do teatro brasileiro: 1570-1908. São Paulo: EDUSP, 1999.

A personagem do teatro. In: CANDIDO, Antonio et al. A Personagem de Ficção. São Paulo: Perspectiva, 2009, p. 81-101.

PRAZ, Mario. A carne, a morte e o diabo na literatura romântica. Trad. Philadelpho Menezes. Campinas, SP: UNICAMP, 1996.

PUNTER, David. The Literature of Terror: a History of Gothic Fictions from 1765 to the Present Day, New York: Longman, 1980.

REBELLO, Luiz Francisco. O Teatro Romântico (1838-1869). Lisboa: Instituto de Cultura e Língua Portuguesa, 1980.

RESENDE, Beatriz. O classicismo francês. In: $O$ teatro através da história. O teatro ocidental. v. I, Rio de Janeiro. São Paulo: CCBG; Entourage, 1994.

RHINOW, Daniela Ferreira Elyseu. A Desdêmona ambígua: Leonor de Mendonça, de Gonçalves Dias. In: Visões de Otelo na cena e na literatura dramática nacional do século XIX. vol. I. São Paulo, 2007, Tese (Doutorado em Literatura Brasileira), Universidade de São Paulo, p. 164-175.

RIBEIRO, Bernardim. História de Menina e Moça. Reprodução facsimilda da edição de Ferrara, 1554. Lisboa: Fundação Calouste Gulbenkian, 2002.

RIBEIRO, Renato Janine. História e revolução: a Revolução Francesa e uma nova ideia de história. Revista USP, v. 1, 1989, p. 12-18.

RODRIGUES, João Bartolomeu. A educação na revista O Panorama. Tomo I. 2008. 185f. Tese (Doutorado em Educação), Universidade de Trás-os-Montes e Alto-Douro, Vila Real, 2008. Disponível em:

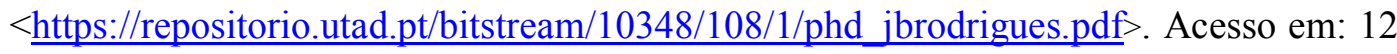
abr.2013.

ROMERO, Sílvio. História da Literatura Brasileira: Transição e Romantismo. Tomo Terceiro. 5 ed., Rio de Janeiro: Livraria José Olympio, 1953.

ROSENFELD, Anatol; GUINSBURG, J. Romantismo e Classicismo. In: GUINSBURG, J. O Romantismo. 2. ed., São Paulo: Perspectiva, 1985, p. 261-274. 
. Da Ilustração ao Romantismo. In: Autores pré-românticos alemães. São Paulo: EPU,1991.

. Teatro Moderno. 2. ed., São Paulo: Perspectiva, 1997

. Literatura e Personagem. In: CANDIDO, Antonio et al. A Personagem de

Ficção. São Paulo: Perspectiva, 2009, p. 11-49.

ROSENFELD, Kathrin Holzermayr (Org.). Filosofia \& Literatura: o trágico. Rio de Janeiro: Jorge Zahar, 2001.

ROUBINE, Jean Jacques. Introdução às grandes teorias do teatro, Trad. André Telles, Rio de Janeiro: Zahar, 2003.

ROUGEMONT, Denis de. A história do amor no Ocidente. Trad. Paulo Brandi e Ethel Brandi Cachapuz. 2. ed. reform., São Paulo: Ediouro, 2003.

SÁ, Carolina Mafra de. Teatro idealizado, teatro possivel: uma estratégia educativa em Ouro Preto (1850-1860). Belo Horizonte, 2009, Dissertação de Mestrado em Educação. Universidade Federal de Minas Gerais.

SAFRANSKI, Rüdiger. Romantismo: uma questão alemã. Trad. Rita Rios. São Paulo: Estação Liberdade, 2010.

SANTOS NETO, Artur Bispo dos. A Filosofia do Romantismo, Maceió: EDUFAL, 2005 .

SANTOS, Silvia Pereira. Caminhos do drama burguês: de Diderot a Alexandre Dumas filho. Darandina: Revista Eletrônica. Programa de Pós-Graduação em Letras / UFJF , vol. $2, n^{\circ} .1$.

SARAIVA, António José. Telmo Pais - A Personagem Central de Frei Luís de Sousa. In: GARRETT, Almeida. Frei Luís de Sousa. Realização didática Luís Amaro de Oliveira. Porto: Porto Editora, 1987, p. 18-22.

SCHILLER, Friedrich, Maria Stuart. Trad. E. P. Fonseca, Rio de Janeiro: Irmãos Pongetti, 1946.

. Teoria da tragédia. Introdução e notas de Anatol Rosenfeld. São Paulo: E.P.U.,1991.

. Poesia ingênua e sentimental. Trad., apres. e notas Márcio Suzuki. São Paulo: Iluminuras, 1991.

. A educação estética do homem numa série de cartas. Trad. Roberto Schwarz e Márcio Suzuki. São Paulo: Iluminuras, 2002. 
. Kallias ou sobre a beleza: a correspondência entre Schiller e Köner, janeiro fevereiro de 1793. Tradução introdução de Ricardo Barbosa. Rio de Janeiro: Jorge Zahar Editor, 2002.

. A noiva de Messina, ou, Os irmãos inimigos: tragédia com coros. Trad. Antônio Gonçalves Dias. São Paulo: Cosac \& Naify, 2004.

. Intriga e Amor: uma tragédia burguesa em cinco atos. Trad. Mario Luiz Frungillo. Curitiba: EDUFPR, 2005

. Do Sublime (Para uma exposição ulterior de algumas ideias kantianas). In: SÜSSEKIND, Pedro. Friedrich Schiller: do sublime ao trágico. Trad. e ensaios Pedro Süssekind e Vladimir Vieira. Belo Horizonte: Autêntica, 2011, p. 19-52.

. Sobre o sublime. In: SÜSSEKIND, Pedro. Friedrich Schiller: do sublime ao trágico. Trad. e ensaios Pedro Süssekind e Vladimir Vieira. Belo Horizonte: Autêntica, 2011, p. 53-74.

SCHLEGEL, August Wilhelm. $37^{\mathrm{a}}$ preleção sobre arte e literature dramáticas. In: SCHILLER, Friedrich. A noiva de Messina, ou, Os irmãos inimigos: tragédia com coros. Trad. Antônio Gonçalves Dias. São Paulo: Cosac \& Naify, 2004, p. 197-198.

SILVA, Edson Santos, Estéticas teatrais portuguesas na época da Garrett. Todas as Musas, Ano 3, n. 1, jul./dez. 2011, p.187.

SILVA, Jorge Bastos da. O Génio e o Desespero: Byron e a Violência da Visão

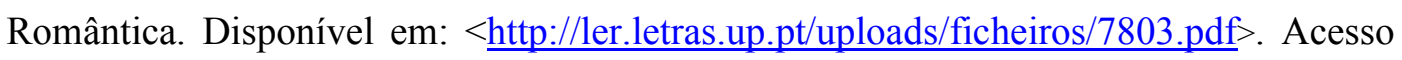
em: 21 abr. 2014.

SILVA, Luciane Nunes da. O Conservatório Dramático Brasileiro e os ideais de arte, moralidade e civilidade no século XIX. Niterói, 2006, Tese (Literatura Comparada). Universidade Federal Fluminense.

SILVA, Raquel Barroso. Teatro nacional: a construção de uma ideia no século XIX. Antiteses, v. 6, n. 12, p. 436-455, jul./dez. 2013.

SMITH, James L. Melodrama. London: Methuen Young Books, 1973.

SOUSA, D. Antonio Caetano de. História genealógica da Casa Real Portugueza. Tomo V, Lisboa: Officina Sylviana, 1738.

SOUSA, Harlon Homem de Lacerda. Tradição e Traição no Drama Histórico: Calabar em revista, no teatro de Chico Buarque. 215 f. 2009. Dissertação (Mestrado em Letras), Universidade Federal da Paraíba, João Pessoa, 2009.

SPINA, Segismundo. A Lírica Trovadoresca. São Paulo: Edusp, 1996, p. 363. 
STAROBINSKI, Jean. Jean Jacques Rousseau: a transparência e o obstáculo; seguido de sete ensaios sobre Rousseau. Tradução Maria Lúcia Machado. São Paulo: Companhia das Letras, 2011.

SÜSSEKIND, Pedro. Shakespeare: o gênio original. Rio de Janeiro: Jorge Zahar Ed., 2008 .

In: Centro Cultural Banco do Brasil. Banco do Brasil apresenta e patrocina a peça Maria Stuart de Schiller, 2009.

. Schiller e a atualidade do sublime. In: SÜSSEKIND, Pedro. Friedrich Schiller: do sublime ao trágico. Trad. e ensaios Pedro Süssekind e Vladimir Vieira. Belo Horizonte: Autêntica, 2011.

SUZUKI, Márcio. $O$ Gênio Romântico: crítica e história da filosofia em Friedrich Schlegel. São Paulo: Iluminuras, 1998.

. "A 'guerra ao naturalismo: a propósito do coro na Noiva de Messina". In: SCHILLER, Friedrich. A noiva de Messina, ou, Os irmãos inimigos: tragédia com coros. Trad. Antônio Gonçalves Dias. São Paulo: Cosac \& Naify, 2004, p. 213-223.

SHAKESPEARE, William. Otelo, o mouro de Veneza. Trad. Bárbara Heliodora, Rio de Janeiro: Nova Fronteira, 2011.

SWIGGER, Nancy Louise Duncan. Gonçalves Dias' Dramas. Ph. D. (Language and Literature), Indiana University, 1969.

SZONDI, Peter. Teoria do Drama Burguês: século XVIII. São Paulo: Cosac Naify, 2004.

TASCA, Michelle Fernanda. A história contada pelos periódicos: O Panorama e a História de Portugal. XXVII Simpósio Nacional de História,ANPUH, 2013, Natal. Anais... Natal: UFRN, 2013

TEIXEIRA, Ivan. Mecenato Pombalino e Poesia Neoclássica. São Paulo: Editora da Universidade de São Paulo, 1999.

THOMASSEAU, Jean-Marie. O Melodrama. Trad. e notas Claudia Braga e Jacqueline Penjon. São Paulo: Perspectiva, 2012.

TORRANO, Jaa. O mundo como função das musas. In: HESÍODO. Teogonia: a origem dos deuses. 7. ed., São Paulo: Iluminuras, 2007.

UBERSFELD, Anne. Le roi et le bouffon: étude sur le théâtre de Hugo de 1830 à 1839 . Paris: Librairie José Corti, 1974.

. Para ler o teatro. Trad. José Simões (Coord.). São Paulo: Perspectiva, 2005. 
VALÉRY, Paul. A tentação de (São) Flaubert. In: FLAUBERT, Gustave. As tentações de Santo Antão. Trad. Luís de Lima, São Paulo: Iluminuras, 2004, p. 7-12.

VASCONCELOS, Ana Isabel P. Teixeira. O drama histórico português do século XIX (1836-1856), Lisboa: Fundação Calouste Gulbekian, 2003.

VASCONCELOS, Ana Isabel. O tratamento da História no drama romântico português. Limite: revista de estúdios portugueses y de la lusofonia, Universidad de Extremadura, $\mathrm{n}^{\circ} \quad 2, \quad 2008, \quad$ pp.79-95. Disponível em: $<$ http://dialnet.unirioja.es/servlet/articulo? codigo=2976423 $>$. Acesso em: 22 fev. 2010.

VASCONCELOS, Sandra Guardini. Subjetividade e mundo doméstico no romance. In: Dez lições sobre o romance inglês do século XVIII. São Paulo: 2002.

A Formação do Romance Inglês: ensaios teóricos. São Paulo: Aderaldo\& Rothschild: Fapesp, 2007.

VERÍSSIMO, José. História da Literatura Brasileira: de Bento Teixeira (1601) a Machado de Assis (1908). 4. ed., Brasília: Editora Universidade de Brasília, 1963.

VIGNY, Alfred de. Chatterton. Paris: Librairie Larousse, s/d.

VIEIRA, Vladimir. Os dois sublimes de Schiller. In: SCHILLER, Friedrich. Do sublime ao trágico. Org. Pedro Sussekind, Belo Horizonte: Autêntica, 2011.

VOLOBUEF, Karin. Frestas e arestas: a prosa de ficção do Romantismo na Alemanha e no Brasil. São Paulo: Fundação Editora da UNESP, 1999.

. Victor Hugo e o grotesco em Notre-Dame de Paris. Lettres Françaises, n. 5., 2003, p. 25-34.

. Friedrich Schiller e Gonçalves Dias. Pandaemonium germanicum. São Paulo: Humanitas, v. 9, p. 77-90, 2005.

WEISKEL, Thomas. O sublime romântico: estudos sobre a estrutura e psicologia da transcendência Trad. Patrícia Flores da Cunha. Rio de Janeiro: Imago, 1994.

WELLEK, René. História da Crítica Moderna. Tradução Lívio Xavier. São Paulo: Herder, 1967, vol. II (O Romantismo).

. WELLEK, René. A crise da Literatura Comparada. In: COUTINHO, EDUARDO F; CARVALHAL, Tania Franco (Orgs.). Literatura Comparada: textos fundadores, 2. ed, Rio de Janeiro: Rocco, 2011.

WERKEMA, Andréa Sirihal. Macário, ou o do drama romântico em Álvares de Azevedo. Belo Horizonte: UFMG, 2012.

WILLIAMS, Raymond. Formas. In: WILLIAMS, Raymond. Cultura. Rio de Janeiro: Paz e Terra, 1992, p. 147-178. 
. Tragédia Moderna. Trad. Betina Bischof, São Paulo: Cosac \& Naify, 2002.

XAVIER, Ismail. Melodrama, ou a sedução da moral negociada. Novos Estudos CEBRAP, n. 57, julho 2000, p. 81-90. 